\title{
Zoutconsumptie en bloeddruk in een huisartspraktijk
}

Citation for published version (APA):

van Binsbergen, J. J. (1986). Zoutconsumptie en bloeddruk in een huisartspraktijk. [, Maastricht University]. Rodopi. https://doi.org/10.26481/dis.19870116jb

Document status and date:

Published: 01/01/1986

DOI:

10.26481/dis.19870116jb

Document Version:

Publisher's PDF, also known as Version of record

\section{Please check the document version of this publication:}

- A submitted manuscript is the version of the article upon submission and before peer-review. There can be important differences between the submitted version and the official published version of record.

People interested in the research are advised to contact the author for the final version of the publication, or visit the DOI to the publisher's website.

- The final author version and the galley proof are versions of the publication after peer review.

- The final published version features the final layout of the paper including the volume, issue and page numbers.

Link to publication

\footnotetext{
General rights rights.

- You may freely distribute the URL identifying the publication in the public portal. please follow below link for the End User Agreement:

www.umlib.nl/taverne-license

Take down policy

If you believe that this document breaches copyright please contact us at:

repository@maastrichtuniversity.nl

providing details and we will investigate your claim.
}

Copyright and moral rights for the publications made accessible in the public portal are retained by the authors and/or other copyright owners and it is a condition of accessing publications that users recognise and abide by the legal requirements associated with these

- Users may download and print one copy of any publication from the public portal for the purpose of private study or research.

- You may not further distribute the material or use it for any profit-making activity or commercial gain

If the publication is distributed under the terms of Article $25 \mathrm{fa}$ of the Dutch Copyright Act, indicated by the "Taverne" license above, 


\title{
ZOUTCONSUMPTIE EN BLOEDDRUK IN EEN HUISARTSPRAKTIJK
}

\author{
PROEFSCHRIFT \\ ter verkrijging van de graad van \\ doctor in de Geneeskunde \\ aan de Rijksuniversiteit Limburg te Maastricht, \\ op gezag van de Rector Magnificus, \\ Prof. Dr. F.I.M. Bonke, \\ volgens het besluit van het College van Dekanen, \\ in het openbaar te verdedigen \\ op vrijdag 16 januari 1987 te 14.00 uur \\ door \\ JACOB-JAN VAN BINSBERGEN \\ geboren te Utrecht in 1946
}

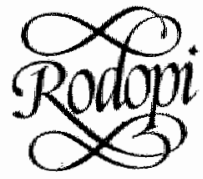

AMSTERDAM 1986 
PROMOTORES: Prof.Dr.Ir. R.J.J.Hermus

Prof.Dr. F. Sturmans

REFERENTEN: Prof.Dr. W.H. Birkenhäger

Prof.Dr. W. Brouwer

Prof.Dr. F. ten Hoor

Dit promotieonderzoek is door de NEDERLANDSE HARTSTICHTING
gesubsidieerd. 
Ik draag dit proefschrift op aan mijn Vader 
1. INLEIDING

1.1. Hypertensie als probleem voor de volksgezondheid 1

1.2. Zoutconsumptie en hypertensie 2

1.3. Doelstelling van het onderzoek : 3

1.4. Opzet van het onderzoeksverslag 4

2. LITERATUURONDERZOEK

2.1. Zoutgebruik in historisch perspectief 5

2.2. Wijze van bepalen van de natrium-, kalium-, calcium- en magnesiuminneming 7

2.2.1. Natrium en kalium 7

2.2.2. Calcium en magnesium 10

2.3. Gevolgen van overmatig keukenzoutgebruik voor de gezondheid 11

2.3.1. Pathofysiologische aspecten 11

2.3.2. Epidemiologische gegevens 15

2.3.2.1. Inleiding 15

2.3.2.2. Problemen bij interpretatie van epidemiologisch onderzoek als gevolg van verschil in onderzoeksopzet 16

2.3.2.3. Natrium 20

2.3.2.4. Kalium 26

2.3.2.5. Molaire natrium/kalium ratio 28

2.3.2.6. Andere mineralen 28

2.4. Niveau van de consumptie van keukenzout en daarmee samenhangende mineralen 29

2.4.1. Inleiding $\quad 29$

2.4.2. Buitenlandse gegevens 30

2.4.3. Nederlandse gegevens $\quad 30$

3. PROBLEEMSTELLING 34

$\begin{array}{ll}\text { 3.1. Inleiding } & 34\end{array}$

3.2. Afbakening van de probleemstelling 35

3.3. Specifieke onderzoekswraagstellingen 35 
4. ONDERZOEKSMETHODE

4.1. Selectie van de onderzoekspopulatie

4.1.1. Het steekproefkader

4.1.2. Het trekken van de steekproef

4.1.3. Uitsluitingscriteria

4.2. De gegevensverzameling

4.2.1. Anamnestische gegevens

4.2.2. Anthropometrische gegevens, bloeddruk en polsfrequentie

4.2.3. De urineverzameling

4.3. De gegevensverwerking

5. RESULTATEN

5.1. Kenmerken wan de 45

5.1.1. De steekproef onderzoekspopulatie 45

5.1.2. De opkomst, deelnemers en 45

5.1.3. De urineverzameldag en niet-deelnemers 45

5.1.4. De anamnese 47

5.2. Anthropometrie, polsfrequentie en bloeddruk 48

5.2.1. Anthropometrie: het lichalamsgewicht, 41 lengte, de kniebreedte

5.2.2. Polsfrequentie, systolische en de Queteletindex 49

5.3. De bepalingen in de 24-uurs diastolische bloeddruk 51

5.3.1. Volume 24-uurs urine 53

5.3.2. Natrium 53

5.3.3. Kalium 54

5.3.4. Molaire natrium/kalium ratio 55

5.3.5. Calcium ratio 57

5.3.6. Magnesium 59

$\begin{array}{ll}\text { 5.3.7. Creatinine } & 60\end{array}$

5.3.8. Molaire natrium/creatinine ratio 61

5.3.9. Molaire kalium/creatinine ratio 62

$\begin{array}{ll}\text { 5.3.10. Natrium per kilogram lichaamsgewicht } & 62\end{array}$

5.3.11.Kalium per kilogram lichaamsgewicht 63

5.4. Invloed van de onafhankelijke op de afhamsgewicht 63

$\begin{array}{ll}\text { 5.5. Samenhang Quetelet-index met de afhankelijke variabelen } & 63 \\ & 64\end{array}$ uitscheiding, de molaire met de natrium- en kaliumbloeddruk matrium/kalium ratio en de

5.6. De voedingsenquêtegegevens en de 24-uurs urinewaarden 66

5.6.1. Vergelijking van de natrium- 24-uurs urinewaarden 69 magnesiumconsumptiegeg-, kalium-, calcium- en 
5.6.2. Bijdrage van de onderscheiden voedingsmiddelen aan de natriuminneming 71

5.7. De tweede urineverzameling - intra-individuele variabiliteit 73

5.7.1. Natrium

5.7.2. Kalium 74

5.7.3. Calcium en magnesium 75

5.7.4. Nadere analyse van de natrium- en kaliumresultaten 76

6. BESCHOUWING VAN DE URINEBEPALINGEN EN DE VOEDINGSENQUETE

7. PRAKTISCHE CONSEQUENTIES: PRIMAIRE EN SECUNDAIRE PREVENTIE VAN HYPERTENSIE

7.1. Maatregelen op individueel niveau 86

7.1.1. Primaire preventie bij risicodragers 86

7.1.2. Secundaire preventie bij hypertensiepatiënten 87

$\begin{array}{ll}\text { 7.2. Maatregelen op populatie-niveau } & 89\end{array}$

7.3. Invoeging in algemeen aanvaard voedingsbeleid: de betekenis van de molaire natrium/kalium ratio 90

SAMENVATTING

SUMMARY

LITERATUUR

SCHEMA'S, TABELLEN EN AFBEELDINGEN 118

BIJLAGEN

179

DANKBETUIGING

CURRICULUM VITAE 



\section{INLEIDING}

\subsection{Hypertensie als probleem voor de volksgezondheid}

Hoge bloeddruk, een hoog serumcholesterolgehalte en het roken van sigaretten vormen de drie belangrijkste risico-indicatoren voor het ont-

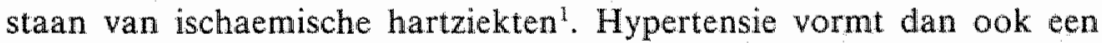
volksgezondheidsprobleem van de eerste orde. Temeer daar deze eveneens bijdraagt aan het ontstaan van het cerebro-vasculair accident, van nierinsufficiëntie en hoogst waarschijnlijk ook van atherosclerotisch vaatlijden in algemene $\operatorname{zin}^{2,3,4,5,6,7,8,9,10}$. Of, om met Birkenhäger te spreken: "Hypertensie gedraagt zich als een sterk pathogene factor ten opzichte van het hart-en vaatstelsel""l.

Het is aannemelijk dat een geringe daling van het gemiddelde bloeddrukniveau van de bevolking een vèrstrekkend positief effect zal hebben op de daling van de incidentie van de met hypertensie samenhangende ziekten ${ }^{12,13,14,15,16,17}$. De Wereldgezondheidsorganisatie (WHO) en de Gezondheidsraad rekenen primaire preventie, (wroege) opsporing en behandeling van hypertensie dan ook tot de hoogste prioriteiten in de gezondheidszorg $8,9,18$. Beard et al verwoorden dit als volgt: "No single advance in community health would improve the quality of life more than the control of hypertension"19.

Zelfs lichte hypertensie (diastolische waarde: $90-100 \mathrm{~mm} \mathrm{Hg}$ ) geldt als een belangrijke risicofactor, wellke in de ogen van sommigen behandeld dient te worden $7,20,21,22,23,24,25$. Een belangrijke stellingname, berekend is namelijk dat er in Nederland ruwweg anderhalf miljoen volwassen personen met een lichte hypertensie zijn ${ }^{8,26}$.

Voorkómen, opsporing en zo nodig behandeling van alle gevallen van hypertensie wordt door de Gezondheidsraad nadrukkelijk tot de taken van de huisarts gerekend ${ }^{1,8}$ " Deze dient dan ook vertrouwd te zijn met de wijze van opsporing. Daar bij de meeste mensen met hypertensie de bloeddruk slechts licht verhoogd is, moet de huisarts zich oriënteren op de te nemen niet-farmacologische maatregelen $1,8,9,27,28,29,30,31,32,33,34$. Immers: "Het therapeutisch regime bij hypertensie behoort het karakter van preventie te dragen", aldus de Gezondheidsraad, die "aandacht" voor de dagelijkse energie-opname en voor het gebruik van keukenzout als belangrijkste bijdrage aan een "verstandige leefwijze" bij lichte hypertensie aanbeveelt ${ }^{3}$. 


\subsection{Zoutconsumptie en hypertensie}

Preventie bij hypertensie dient erop gericht te zijn om - door maatregelen in de sfeer van de primaire en secundaire preventie - de prevalentie en incidentie van dit gezondheidsprobleem te beperken door de bekende risicofactoren te verminderen dan wel te elimineren. Zoutgebruik - of beter gesteld de hoogte van de natriuminneming - is één van die risicofactoren.

De zout-bloeddruktheorie is evenwel nog controversieel. Enerzijds zijn ook andere mineralen als kallium, calcium en magnesium van essentièle betekenis bij de bloeddrukregulatie en wel in nauwe onderlinge samenhang met natrium ${ }^{35}$. Zo meent Langford dat de molaire natrium $/ \mathrm{kalium}$ ratio van de voeding moet worden gezien als: "the major controlling factor in blood pressure" 36,37 . Anderzijds geldt dat de relevantie van ieder van de factoren niet alleen wordt bepaald door de sterkte van het verband tussen de risicofactor en de ziekte (het relatieve risico) doch eveneens door de prevalentie van deze risicofactor in de bevolking. Samen bepalen zij het zogenaamde populatie-attributieve risico of wel de etiologische fractie van de ziekte, die voor rekening komt van de betreffende risicofactor $^{38}$. Een en ander betekent dat - wil men de bijdrage van de zoutconsumptie aan het hypertensieprobleem kunnen schatten - twee soorten gegevens nodig zijn: enerzijds gegevens over de dosis-respons relatie tussen zoutgebruik en bloeddrukregulatie en anderzijds gegevens over de hoogte van het zoutgebruik door en de spreidingsbreedte hiervan in de bevolking. Met name over dit laatste is nog onvoldoende bekend in Nederland. Uit het voorafgaande volgt overigens dat de invloed van risicofactoren op populatieniveau anders kan zijn dan op individueel niveau. Factoren met een sterk verhoogd risico op individueel niveau, die weinig in de populatie vóorkomen, zullen slechts van geringe invloed zijn op hypertensie als algemeen gezondheidsprobleem. Factoren met een licht verhoogd risico, die juist frequent in de bevolking vóórkomen, kunnen daarentegen verhoudingsgewijs een sterk ongunstige bijdrage leveren an het hypertensieprobleem. Of, anders geformuleerd: zelfs een matige daling van de grootte van een risicofactor, die bij veel mensen vớorkomt, zal een belangrijke uitwerking kunnen hebben op het reduceren van de betekenis van een volksgezondheidsprobleem ${ }^{13}$.

In dit verband wijst de WHO dan ook - in weerwil van de nog lopende discussie over de sterkte van het relatieve risico - met klem op de noodzaak het doorgaans veell te hoge zoutgebruik per hoofd wan de bevolking in de geindustrialiseerde wereld, tot 3 à 5 gram te laten dalen ${ }^{3,18}$. De Gezondheidsraad en Voedingsraad volgen dit advies slechts gedeeltelijk. Alvorens hiertoe over te gaan achten zij het namelijk wenselijk dat meer gegevens beschikbaar komen over de aard van het 
verband tussen zoutgebruik en bloeddruk. Zij stellen een keukenzoutconsumptie van 9 gram als aanvaardbare bovengrens $s^{8,39}$. De werkelijke relevantie van deze informatie blijt echter - zoals uit het voorafgaande is gebleken - beperkt, zolang niet tevens nauwkeuriger gegevens over de hoogte van het zoutgebruik door de bevolking beschikbaar zijn. Daarbij rijst de vraag of (zoals door de WHO wordt verondersteld) de zoutconsumptie niet dusdanig hoog is, dat verder afwachten - althans bij risico-dragers - onverantwoord is ${ }^{18,40}$. Gemakkelijk te identificeren groepen, waarbij preventie "relatief rendabel" is, will de Gezondheidsraad namelijk bij preventieve maatregelen betrekken'. Men denkt hierbij enerzijds aan personen met een belaste familie-anamnese voor hart-en vaatziekten en anderzijds hypertensiepatiënten!. Een vermindering van de zoutconsumptie door deze groep personen wordt door de Gezondheidsraad, wenselijk en ook haalbaar geacht ${ }^{8}$.

\subsection{Doelstelling van het onderzoek}

Een aanzienlijk aantal personen komt - volgens de thans geldende inzichten - voor een natriumbeperkte voeding in aanmerking. Het reduceren van de dagelijkse zoutconsumptie is echter niet eenvoudig. Menigeen is onkundig van de soms niet geringe hoeveelheden natrium in de gangbare, dagelijkse voeding ${ }^{41,42}$. De reactie: "dokter, ik gebruik al zo weinig zout" zal dan ook geen huisarts vreemd zijn. Toch doet literatuuronderzoek vermoeden, dat de hoogte van het natriumgehalte in de dagelijkse voeding de fysiologische behoefte $(10-50 \mathrm{mmol})$ vele malen overschrijdt. De vraag, hoe hoog het zoutgebruik van de personen met een belaste familie-anamnese en degenen die wegens hypertensie worden behandeld, mu werkelijk is, is voor de huisarts - gezien de aan hem toebedeelde taak - dan ook uiterst relevant. Overigens zijn de consequenties van deze toebedeelde taak verstrekkend. Anticiperende geneeskunde, zo schrijft De Melker immers, "probeert op grond van bepaalde risico-indicatoren door middel wan medische interventie toekomstige negatieve ontwikkelingen zoveel mogelijk te voorkómen"43. Men dient zich evenwel te realiseren dat de vraag op welke schaal in dit verband "geanticipeerd" moet worden, niet alleen afhangt van de gemiddelde hoogte van het zoutgebruik maar ook van het percentage personen dat boven een vastgestelde norm ligt. Woorts is kennis betreffende het gebruik van voedingsmiddelen die bijdragen aan deze hoge natriuminneming in dit verband van cruciale betekenis. Naarmate natriumrijke produkten een meer centrale plaats innemen in het voedselpakket, zijn de mogelijkheden tot wijziging van het voedingspatroon beperkter. Het gaat hierbij owerigens niet alleen om natrium doch, zoals 
reeds opgemerkt, ook om de inneming van kalium, calcium en magnesium.

Samenwattend kan worden gesteld dat het vergaren van kennis omtrent hoogte en herkomst van het zoutgebruik van de bevolking enerzijds nodig is om een schatting te kunnen maken van het risico, dat de consumptie wan zout, gegeven een relatie tussen zoutgebruik en het ontstaan wan hypertensie oplevert, anderzijds om inzicht te verkrijgen in de mate en de richting waarin een inspanning moet worden geleverd dit gebruik te verlagen. Met deze doelstelling voor ogen is dit onderzoek verricht.

\subsection{Opzet van het onderzoeksverslag}

In het navolgende wordt een uiteenzetting gegeven van de resultaten van een literatuuronderzoek naar het zoutgebruik in historisch perspectief, de wijze van bepalen van de hoogte van de natrium-, kalium-, calcium- en magnesiuminneming, de pathofysiologische en epidemiologische aspecten van deze mineralen bij de bloeddrukregulatie en van de huidige stand van de kennis omtrent de hoogte van het zoutgebruik.

Vervolgens worden aan de hand van de resultaten van het literatuuronderzoek de specifieke onderzoeksvraagstellingen geformuleerd.

$\mathrm{Na}$ beschrijving en beschouwing van de resultaten van het uitgevoerde eigen onderzoek, worden de praktische consequenties van deze uitkomsten besproken. Bezien wordt of, en zo ja bij welke groepen, primair preventieve maatregelen genomen dienen te worden, welke consequenties de gevonden waarden hebben voor de aan de huisarts toegedachte taak inzake de hypertensiebestrijding en of ondersteunende overheidsmaatregelen op voedingsgebied deze taak effectiever kunnen maken. 


\section{LITERATUURONDERZOEK}

\subsection{Zoutgebruik in historisch perspectief}

Tal van auteurs wijzen erop dat de mens in zijn ontwikkelingsgeschiedenis steeds meer natrium en minder kalium is gaan gebrui$\operatorname{ken}^{44,45,46,47,48,49}$. Van de oermens wordt aangenomen, dat hij goeddeels vegetarisch leefde. Dat betekent, dat hij veel kalium en weinig natrium gebruikte, want planten zijn rijk aan eerstgenoemde en arm aan laatstgenoemde stof. Uit fysiologisch oogpunt bezien, heeft het voedingspatroon van de wroegere mens overigens ruimschoots in de behoefte aan natrium kunnen voorzien. De dagelijkse natriuminneming van de Australeopithecus wordt op $10 \mathrm{mmol}$ geschat ${ }^{46,47,48}$. Vermoedelijk werd deze hoeveelheid bij "primitieve" volkeren reeds overschreden. Uit moderne onderzoekingen blijkt dat natuurvolkeren, die zich via voedselverzameling en jagen in leven houden, de helft van de benodigde energie uit plantaardige en de helft uit dierlijke voeding halen ${ }^{47}$. Aangezien dit laatste deel relatief natriumrijk en kaliumarm is, neemt de natriuminneming toe, zij het nog niet sterk want extra zout blijkt door deze volkeren doorgaans niet te worden toegevoegd ${ }^{46,50}$.

Heel anders is de situatie bij cultuurvolkeren. Zout "bevordert" de smaak en wordt derhalve bij de voedselbereiding gaarne toegepast. Tevens geldt dat natrium een onmisbare functie vervult bij de bedrijfsmatige bewerking van tal van produkten ${ }^{51,52}$. Zeker zo'n belangrijke verklaring voor de toeneming van het gebruik is tenslotte dat zout heel wel gebruikt kan worden als conserveringsmiddel $1^{44,53,54,55}$. Vis, vlees en ook groenten en melkprodukten worden sinds jaar en dag gepekeld, de laatste in de vorm van kaas en bote ${ }^{56}$. Overigens is de behoefte aan natrium als conserveringsmiddel na de algemene introductie van de koeltechniek afgenomen ${ }^{52,57}$.

Het gevolg van een en ander is, dat de voeding in de moderne geindustrialiseerde landen thans wordt gekenmerkt door een relatief hoog natrium- en een laag kaliumgehalte. Het wijdverbreide gebruik om sterk gezouten produkten te consumeren kan hebben bijgedragen aan het verloren gaan van het vermogen om via de smaak de natuurlijke behoefte aan natrium te peilen. Overmatig zoutgebruik laedeert het smaakzintuig waardoor het discriminerend vermogen afneemt ${ }^{57,58,59}$. De detectiedrempel wordt hoger ${ }^{60}$. 
De Voedingsraad heeft voor Nederland berekend, dat circa $17 \%$ van de hoeveetheid natrium die dagelijks gemiddeld wordt opgenomen, van nature in het voedsel aanwezig is; $30-40 \%$ zou huishoudelijk aan voedingsmiddelen worden toegevoegd en 40-50\% tijdens de "bedrijfsmatige" bewerking van voedselprodukten. Brood, vleeswaren, kaas, soepen en sauzen behoren tot de voedingswaren waaraan veel zout wordt toegevoegd tijdens het produktieproces. Zij leveren, mede door hun belangrijke aandeel in de gemiddelde voeding, een aanzienlijke bijdrage aan de dagelijkse natriuminneming ${ }^{51,52}$. Ook vlees, gevogelte, vis, melk en melkprodukten leveren in dit verband een substantiële bijdrage ${ }^{61}$. Het drinkwater levert met gemiddeld $3 \%$ een relatief klein aandee ${ }^{51,52}$. (Zie schema 1). Het is overigens opmerkelijk, dat de belangrijkste voedingsbronnen voor natrium tevens belangrijke calcium-en magnesiumleveranciers zijn. Zo zijn melk en melkprodukten voorname calciumbronnen en bevatten brood, kaas, vlees en vis veel magnesium ${ }^{47,62}$.

Zoals uit de bespreking in paragraaf 2.3. zal blijken, zijn natrium en kalium fysiologisch nauw met elkaar verbonden. Daarom dient ook het kaliumgehalte van de voeding - met name in relatie tot de hoeveelheid natrium - in dit kader te worden bezien. Groente, aardappelen en fruit gelden als de voornaamste kaliumbronnen ${ }^{62}$. Bij volkeren die zich overwegend vegetarisch voeden zal de natrium/kalium ratio van de voeding laag zijn; plantaardig voedsel bevat immers weinig natrium en veel kalium. Alleen al door dit feit leidt een overgang naar een meer dierlijke voeding tot een verlaging wan de kaliuminneming en een verhoging van de natriumconsumptie ${ }^{63}$. Daar komt nog bij, dat tijdens de bewerking van voedsel in het algemeen wel natrium- maar geen kaliumzouten worden toegevoegd. Tenslotte is aangetoond, dat het gehalte van kalium onder invloed van de bereiding en bewerking vaak afneemt. De molaire natrium/kalium ratio wordt aldus groter. Tabel 1 geeft hiervan enige voorbeelden ${ }^{64,65}$. Als meest extreme voorbeeld komt hieruit naar woren, dat de natrium/kalium ratio bij de verwerking van erwten tot blikerwten 1000 maal groter kan worden.

De molaire natrium/kalium ratio van moedermelk bedragt 0,6 tot $0,7^{66}$. Indien deze ratio als afspiegeling van de natuurlijke behoefte beschouwd zou mogen worden, betekent dit dat de natrium/kalium verhouding in het voedselpakket in de westerse wereld met 2,4 tot 5 of hoger erg ongunstig ligt, namelijk 4 tot 8 keer te hoog 67,68 .

Het is de vraag welke gevolgen de hier geschetste ontwikkelingen hebben voor de gezondheid. In de volgende paragraf zal echter eerst worden ingegaan op de wijze waarop de natrium-, kalium-, calcium- en magnesiuminneming kunnen worden bepaald. 
2.2. Wijze van bepalen van de natrium-, kalium- calcium-en magnesiuminneming

\subsubsection{Natrium en kalium}

Teneinde antwoord te kunnen geven op de vraag hoeveel natrium en kalium een persoon consumeert, kunnen twee wegen worden bewandeld: a. schatting van de totale hoeveelheden in de geconsumeerde voeding. b. metingen in alle excreta.

ad a. Bij de bepaling van de hoeveelheid natrium en kalium in de voeding staan twee methoden ter beschikking: het voedings-anamnestisch onderzoek en de chemische analyse van woedingsmonsters. Bij voedingsanamnestisch onderzoek wordt mondeling of schriftelijk vastgesteld hoe het voedingspatroon er uit ziet. Vervolgens berekent men aan de hand van een voedingsmiddelentabel de samenstelling van die voeding $69,70,71,72,73,74$. Aan de anamnestische methode kleven cen aantal bezwaren. Met name de juistheid van de opgegeven hoeveelheden kan te wensen overlaten. Daarom wordt soms gebruik gemaakt van weegprocedures, waarbij de respondent de hoeveelheden nauwkeuriger kan vaststellen. Voorts is met betrekking tot het meten van de natrium- en kaliumconsumptie een probleem, dat de bestaande voedingsmiddelentabellen slechts van een beperkt aantal toebereide produkten het gehalte aan deze stoffen bevatten 75,76 . Het volledig "omrekenen" van anamnestische gegevens is daarom veelal niet mogelijk $\mathrm{k}^{51}$. Ook kan het zout dat tijdens bereiding en consumptie van de maaltijd wordt toegewoegd, op deze wijze niet zonder meer worden bepaald ${ }^{51}$. Overigens is aangetoond dat keukenzout meestal tijdens de maaltijdbereiding wordt toegevoegd en niet aan tafel ${ }^{77}$. Bij de chemische analyse van voedingsmonsters onderscheidt men drie benaderingen ${ }^{69}$ :

1. de "dubbele portie" methode - een extra hoeveelheid voedsel, gelijk aan al het geconsumeerde voedsel wordt, additioneel bereid en chemisch geanalyseerd,

2. de zogenaamde "aliquot sampling" methode - hierbij wordt slechts een representatief deel van het geconsumeerde voedsel bemonsterd en geanalyseerd,

3. de "equivalent composite" methode - een hoeveelheid onbereide voedingsmiddelen overeenkomstig de gemiddelde dagconsumptie, wordt ingekocht, bereid en onderzocht.

Genoemde methoden zijn gevoelig voor bias, bewerkelijk en kostbaar en derhalve op grote schaal moeilijk uitvoerbaar. Bovendien is het ook in deze gevallen in de praktijk nauwelijks mogelijk de aan tafel toegevoegde hoeveelheid zout of andere natriumhoudende, smakbevorderende stof- 
fen te schatten ${ }^{51}$. Dat geldt ook voor al hetgeen tussen de maaltijden door wordt gegeten.

Samenvattend kan gesteld worden dat de chemische analyse van voedingsmiddelen geen aantrekkelijke methode is ter bepaling van de hoogte van de natrium- en kaliuminneming. Het voedingsanamnestisch onderzoek is in de praktijk beter uitvoerbaar, doch geeft evenmin wolledige informatie. De waarde van dit onderzoek schuilt vooral in thet feit dat het mogelijk is om in korte tijd een redelijk goed inzicht te verkrijgen in de consumptie van een aantal bekende, belangrijke natriumen kaliumrijke voedingsmiddelen.

ad b. Natrium verlaat langs verschillende wegen het lichaam: 90-95\% van de totale hoevelheid opgenomen natrium wordt door de nieren uitgescheiden ${ }^{47,78,79,80}$. Van de resterende 5 à $10 \%$ wordt het grootste deel via de zweetklieren uitgescheiden. Onder normale omstandigheden bedraagt deze hoeveelheid echter niet meer dan $10 \mathrm{mmol}$ per dag $47,78,79,80$. Daarnaast verlaat een kleine hoeveelheid natrium het lichaam via de darm, terwijl ook huidschilfers, speeksel, semen en menstruatiebloed minimale hoeveelheden natrium bevatten ${ }^{47,78}$. Ook voor kalium geldt, dat de uitscheiding via de de darm en zweetklieren te verwaarlozen is ten opzichte van de urine-excretie ${ }^{47,62 ; 79}$.

De excretie via de urine van natrium en kalium zal onder normale, fysiologische omstandigheden een goede maat kunnen zijn voor de totale inneming van deze electrolyten ${ }^{51,78,81}$. De bepaling van de natrium- en kalliumexcretie in de urine kan plaatsvinden in:

1. één enkele urine portie,

2. urine, verzameld over een aantal uren,

3. urine verzameld over één of meer perioden van 24 uur.

ad 1. Deze zogenaamde "spotmeting" is géén betrouwbare maat voor de dagelijkse natriuminneming door het betrokken individu. Pietinen et al toonden binnen één 24-uurs periode een duidelijke fluctuatie in natriumuitscheiding aan ${ }^{82}$. Deze houdt wellicht verband met de omgevingstemperatuur, met houdingsveranderingen dan wel met de 24 uurs rit-

Hoewel Dauncey en Widdowson een correlatie vonden tussen de kaliumconcentratie in één geloosde portie urine en die in de 24-uurs urine, is over de 24 -uurs fluctuatie in dezen onvoldoende bekend ${ }^{83}$. Voor het bepalen van de dagelijkse kaliuminneming, heeft de spotmeting
onvoldoende waarde.

ad 2. De natrumbepaling in urine, welke gedurende een bepaald aantal 
uren is verzameld, verschaft meer inzicht in thet dagelijks gebruik. Langford, Watson en ook Pietinen et al vonden een goede correlatie tussen de natriumuitscheiding in de urine die in de nachtelijke uren werd verzameld en de 24 -uurs urine $79,82,84$. Een bezwaar tegen deze methode blijft evenwel dat individuele verschillen in dag- en nachtritme de berekening van de totale 24-uurs natriumconsumptie onbetrouwbaar maken $^{51,81}$. Naar de waarde van deze methode inzake kalium is, voor zover bekend, geen onderzoek verricht.

ad 3. De natrium- en kaliumuitscheiding in de 24-uurs urine wordt algemeen als de meest betrouwbare maat beschouwd voor het dagelijkse gebruik. Dat geldt althans op populatieniveau ${ }^{79,81}$. Voor het vaststellen van de hoogte van het individuele gebruik is één enkelle verzameling onvoldoende. De sterke intra-individuele variabiliteit in natriumuitscheiding zou een herhaling tot 9 à 14 maal noodzakelijk maken om een voldoende betrouwbare schatting te kunnen maken van de gemiddelde natriumexcretie wan een individu $81,85,86$. Of voor het bepalen van de individuele kaliuminneming een zelfde aantal 24-uurs verzamelingen is vereist, is onvoldoende bekend ${ }^{47,62,79}$.

Uiteraard geeft de hoogte van de natrium- en kaliumexcretie geen informatie over de herkomst uit de voeding. Een scheiding tussen huishoudelijk toegevoegd en reeds in het voedingsmiddel aanwezig natrium kan niet worden gemaakt. In dit verband werd opmerkelijk onderzoek verricht door Sanchez-Castillo et $\mathrm{al}^{87}$. $\mathrm{Zij}$ voegden in een experimenteel onderzoek lithium aan het verstrekte zout toe. Lithium heeft een overeenkomstig uitscheidingspatroon als natrium. Het lithiumgehalte in de 24 -uurs urine bedroeg slechts $17 \%$ van het totale natriumgehalte, aanzienlijk lager dan de schatting door de Voedingsraad van de hoeveelheid huishoudelijk toegevoegd natrium ${ }^{52}$. Samenvattend kan worden geconcludeerd dat om een beeld te krijgen van de hoogte van de gemiddelde natrium- en kaliuminneming van een groep personen één 24-uurs urineverzameling per persoon voldoende kan zijn. De spreiding rond het gemiddelde zal echter zowel de intra- als inter-individuele variatie bevatten en dientengevolge niet mogen worden geinterpreteerd als de werkelijke spreiding in zoutgebruik tussen individuele personen.

De betrouwbaarheid van de 24-uurs bepaling valt of staat uiteraard met de volledigheid van de urineverzameling ${ }^{79,81}$. Een daadwerkelijk betrouwbare en uitvoerbare manier om de volledigheid van de verzameling te testen, is niet beschikbaar ${ }^{78,86}$. De creatinineuitscheiding, die een mat is voor de spierstofwisseling, vertoont tussen personen verschillen tengevolge van verschillen in lichaamsbouw, leeftijd, geslacht en biolo- 
gische variabiliteit. Ook kan de creatinineuitscheiding binnen één individu van dag tot dag enigszins variëren. Dit maakt controle op de volledigheid van de verzamelde urine op grond van deze parameter onbetrouwbaar ${ }^{78,85,88,89}$. Slechts grove onnauwkeurigheden bij de verzameling zijn aan de hand van de creatinineuitscheiding op te sporen ${ }^{90}$.

In recent onderzoek werden de resultaten gerapporteerd van het gebruik van para-aminobenzoëzuur als verklikker ${ }^{91}$. De gedachte hierbij is dat deze stof snel en volledig in de urine wordt uitgescheiden en aldus een maat vormt voor de volledigheid van de 24-uurs urine. Ook aan deze methode klleven evenwel bezwaren. In hoofdstuk 6 wordt op deze methode en op de creatinineuitscheiding nog uitwoerig ingegaan. Zorgvuldige instructie over de wijze van verzamelen lijkt naast een goede relatie mett de onderzoekspopulatie vooralsnog de beste waarborg voor een wolledige urinewerzamelling.

\subsubsection{Calcium en magnesium}

In tegenstelling tot natrium en kalium, die vrijwel geheel geabsorbeerd en via de nieren uitgescheiden worden, verlaten calcium en magnesium slechts gedeeltelijk langs deze weg het lichaam. De hoeveelheid calcium, die dagelijks met de urine verloren gaat, wisselt en is niet alleen afhankelijk van de samenstelling van het voedsel ${ }^{47,62,92,93}$. Bij een calciumrijke voeding neemt de excretie van calcium in de urine enigszins toe. Het gebruik van een eiwit-, fosfaat- en - naar gemeend wordt - ook een keukenzoutrijke voeding, doet de calciumuitscheiding in de urine stijgen $^{93}$. Geslachtshormonen zouden een beschermende werking hebben op het calciumverlies ${ }^{92}$. Vitamine $\mathrm{D}$ bevordert de absorptie van calcium in de darm en gaat zo verlies met de faeces tegen. Naar men veronderstelt, verlaat $10-35 \%$ van de geconsumeerde hoeveelheid calcium het lichaam via de urine $47,62,94$.

Ook voor magnesium geldt, dat het grootste deel ongeabsorbeerd het lichaam via de darm verlaat ${ }^{47,62}$. Een eitwit-en calciumrijke voeding kan - evenals alcohol - de absorptie ongunstig beïnvloeden ${ }^{62}$. Vitamine D zou de opname van magnesium in het spijsverteringskanaal ook bevorderen ${ }^{47}$. Verondersteld wordt, dat ongeveer een derde deel van de totaal geconsumeerde hoeveelheid magnesium door de nieren wordt uitgescheiden ${ }^{62}$. Een en ander betekent, dat de hoogte van de calcium- en magnesiumuitscheiding in de 24-uurs urine slechts een beperkte afspiegeling is van de totale inneming van deze ionen. Over de grootte van de intraindividuele variabiliteit van de calcium-en magnesiumuitscheiding in de urine, zijn geen goede gegevens beschikbaar. Wil men zich een beeld vormen van de dagelijkse calcium- en magnesiuminneming, dan kan het voedingsanamnestisch onderzoek een waardevolle aanvulling betekenen 
op de urinegegevens. Het calciumgehalte van veel roedingsmiddelen is bekend. Bovendien is het aantal voedingsbronnen dat een belangrijke bijdrage levert aan de dagelijkse calciuminneming gering ${ }^{62}$. Magnesium komt daarentegen in veel voedingsmiddelen voor ${ }^{62}$. Hoewel de Nederlandse Voedingsmiddelentabel wel calciumwaarden maar geen magnesiumcijfers vermeldt voor voedingsmiddelen, zijn well gegevens beschikbaar ${ }^{62,76}$. Door de consumptie van een aantal belangrijke magnesiumrijke produkten anamnestisch te bepalen, is het magnesiumgehalte vervolgens te berekenen.

Samenvattend kan men stellen dat op populatie-niveau met behulp van de 24-uurs urineverzameling gegevens verkregen kunnen worden die indicatief zijn voor de hoogte van de natrium-en kaliuminneming. De grootte van de intraindividuele variabiliteit van de uitscheidingswaarden van genoemde ionen kan worden bepaald aan de hand van een herhaalde 24-uurs urineverzameling. Tevens levert voedingsanamnestisch onderzoek naar de hoogte van het gebruik van een aantal natrium- en kaliumrijke voedingsprodukten gegevens op, die afgezet kunnen worden tegen de totale inneming. Op deze wijze kan de relatieve bijdrage van deze voedingsmiddelen aan de natriuminneming worden bepaald. Voedingsanamnestisch onderzoek naar het gebruik van de belangrijkste calciumen magnesiumbronnen verschaft een indicatie over de hoogte van de dagelijkse inneming van deze elementen.

\subsection{Gevolgen van overmatig keukenzoutgebruik voor de gezondheid}

\subsubsection{Pathofysiologische aspecten}

Natrium en kalium zijn onmisbare elementen voor het handhaven van de homeostase in het organisme. Zij spelen een belangrijke rol in de regeling van het zuur-base evenwicht en bij de volumeregulatie. Dit laatste komt tot uitdrukking in het feit dat natrium en kalium te maken hebben met de regulatie van de bloeddruk ${ }^{47,62.95}$. Voor dieren die op het land leven, is natrium een moeilijk te bemachtigen en in die zin schaarse stof ${ }^{44,96,97,98}$. Zo is drinkwater natriumarm en bevat ook plantaardig. voedsel over het algemeen weinig natrium.

Daar een tekort aan natrium levensbedreigend is, beschikt het landdier en ook de mens over natriumsparende mechanismen ${ }^{47,49,57,79}$. Het belangrijkste daarvan is het renine-angiotensine-aldosteron systeem. Schema 2 geeft dit weer ${ }^{99}$.

Kort samengevat houdt dit in, dat de nier onder invloed van informatie uit chemo- of baroreceptoren in de juxtaglomerulaire cellen renine produceert, zodra het natriumgehalte in het glomerulusfiltraat te ver daalt of de renale perfusiedruk afneem $t^{100}$. Het afgescheiden renine vormt 
met het in de lever geproduceerde angiotensinogeen het inactieve angiotensine $I$, dat door inwerking van angiotensin converting enzyme (ACE) in angiotensine II wordt omgezet. Dit doet de gladde musculatuur van de perifere arteriolen contraheren. Tevens prikkelt angiotensine II de bloeddrukregulerende centra ${ }^{100}$. Ook stimuleert het de bijnierschors tot de afgifte van aldosteron. Dit aldosteron induceert op zijn beurt de terugresorptie van natrium en water in de distale tubuli van de nier en waarschijnlijk ook in de darmen, de speeksel- en de zweetklieren ${ }^{96,101,102}$. Aldus wordt ervoor gezorgd dat natriumverlies beperkt wordt en dat het plasmavolume en het osmotisch evenwicht op peil blijven.

Is natrium een schaars element voor landdieren, dit geldt normaal gesproken minder voor kalium. Kalium is in plantaardig voedsel in ruime mate aanwezig. Wellicht is het om die reden, dat het lichaam niet over kaliumsparende mechanismen beschikt. Overvloedig kalium ondersteunt, onder fysiologische omstandigheden, de natriumsparende functie van het lichaam ${ }^{103}$.

Uit het bovenstaande moge duidelijk zijn geworden, dat het lichaam over mechanismen beschikt om het natrium vast te houden. Sedert het begin van deze eeuw is wooral over de invloed van een relatief natriumrijke buitenwereld op de fysiologie van de mens meer inzicht verworven $46,78,104,105,106$. Het "milieu interieur" moet juist worden beschermd tegen het zoutrijke "milieu exterieur", in casu de zoute voeding. Wat gebeurt er wanneer meer natrium dan fysiologisch nodig is, wordt opgenomen? Bij de beantwoording van deze vraag moet onderscheid worden gemaakt tussen een kort durende en een chronische zoutbelasting van het lichaam. In het eerste geval zal het natriumgehalte van het plasma stijgen. Dit zal onder invloed van het genoemde renine-angiotensinealdosteron systeem tot dorstprikkels leiden. $\mathrm{Na}$ het drinken zal het extracellulaire volume toenemen en als gevolg daarvan daalt de natriumconcentratie in het plasma weer. Bovendien treedt er water uit de cel, hetgeen eveneens tot herstel van de osmotische verhoudingen leidt. Een belangrijke rol bij deze normalisatie speelt het anti-diuretisch hormoon $(\mathrm{ADH})$, dat uittreding van vocht uit het lichaam voorkomt $48,104,107,108,109$. Als tweede instantie zal het lichaam proberen het teveel aan zout te verwijderen. Dit komt tot stand doordat de genoemde toename in het extra-cellulaire volume gepaard gaat met een toename van het hartminuut volume. Bij gelijkblijvende perifere vaatweerstand leidt dit tot bloeddrukverhoging en aldus tot een verhoging van de perfusiedruk in de nieren. Dit leidt er op zijn beurt toe dat de nier meer natrium en water gaat uitscheiden, waarna het extra-cellulaire volume daalt en vervolgens ook de bloeddruk. Op deze summier geschetste wijze bewaakt het lichaam zijn natriumbalans bij acute verstoringen. 
Deze door Ambard en Beaujard reeds in 1904 en later door Starling in 1909 beschreven theorie bleek ontoereikend om het ontstaan van hypertensie te verklaren. Ook na het verschijnen van de publicatie van Borst et al over het Starlingmechanisme inzake hypertensie in 1963 , bleven er vraagtekens bestaan ${ }^{105,106}$. De laatste jaren lijkt er evenwel meer duidelijkheid in deze problematiek te komen doordat men systematisch onderscheid is gaan maken tussen chronische en acute zoutbelasting. Wanneer wia de voeding langdurig veel natrium wordt opgenomen, verloopt het bovenbeschreven mechanisme anders - het systeem derangeert als het ware. Na verloop van tijd daalt namelijk het extracellulaire volume en daarna het hart-minuut volume ${ }^{10,111}$. Dit latste betekent echter niet, dat de bloeddruk daalt. Deze blijft in vele gevallen hoog hetgeen naar recentelijk is gebleken, te wijten is, aan een verhoging van de perifere vaatweerstand $48,111,112,113,114,115$. De oorzaak wordt hierin gezocht dat de relatief grote hoeveelheid natrium die de cellen omspoelt de vaatwand doet contraheren. Dit zou langs verschillende wegen kunnen gebeuren $^{116}$.

Luft et al stellen dat een hoge natriumconcentratie de prikkelbaarheid van het sympathisch zenuwstelsel via de juxtaglomerulaire cellen verhoogt, hetgeen tot vasoconstrictie leidt ${ }^{117,118}$. Een tweede verklaring stoelt eveneens op electrofysiologische overwegingen. Tijdens prikkeling van spier- en zenuwcellen treden verschuivingen op in het ionenevenwicht. Natrium, dat zich in rusttoestand vooral extra-cellulair bevindt, gaat de cel binnen en vervangt een deel van het aldaar aanwezige kalium dat de cel verlaat. De hiermee gepaard gaande depolarisatie wordt door een repolarisatie gevolgd, waardoor de oorspronkelijke electrische gradiënt wordt hersteld. Daarbij dringt weer kalium naar binnen en natrium naar buiten. $\mathrm{Nu}$ is de laatste jaren duidelijk geworden dat de wisseling van natrium en van kalium onder invloed lijkt te staan van de natrium- en kaliumconcentraties. Veel natrium remt, veel kalium stimuleert de $\mathrm{Na} / \mathrm{K}$ pompfunctie. Friedman stelt, dat bij het - door het enzym Natrium/KaliumAdenosinetrifosfatase ( $\mathrm{Na} / \mathrm{K}$ ATP-ase) gekatalyseerde - wisselmechanisme zeer veel energie wordt verbruikt. Zijn hypothese luidt dat tengevolge van een verstoorde pompfunctie, te veel intra-cellulair natrium achterblijft. Dit zou een toeneming van het celvolume door vochtophoping met zich mee brengen. De cel zwelt op en kan zo een vernauwing van het lumen van de arteriolen bewerkstelligen, hetgeen tot een vergroting van de perifere vaatweerstand leidt $103,108,119,120,121,122,123$.

Een derde verklaring slluit bij het bovenstaande aan. Er zijn aanwijzingen dat tengevolge van het verstoorde intra-cellulaire natriumevenwicht en de natrium accumulatie in de cel ook de intra-cellulaire calciumconcentratie groter wordt. McCarron, Cohn en Blaustein ver- 
richtten onderzoek waaruit bleek, dat het bestaande natrium/calcium wisselmechanisme onder invloed van een natriumrijk milieu onvoldoende functioneert. Het gevolg is een verhoging van de prikkelbaarheid van de gladde musculatuur van de kleine bloedvaten. De contractiliteit neemt daardoor toe en zo ook de perifere vaatweerstand. Ook magnesium, als natuurlijke antagonist van calcium, lijkt in dezen een rol van betekenis te spelen $124,125,126,127,128,129,130,131$. Een recent gepubliceerd literatuuroverzicht suggereert bovendien een samenhang tussen een verhoogd intracellulair calciumgehalte en hypercholesterolaemie ${ }^{132}$.

Aldus lijkt het ontstaan van hypertensie bij een nagenoeg normaal extra-cellulair volume en een normaal hart-minuut volume verklaard te kunnen worden. Toch is de ontstane verhoogde bloeddruk niet "functioneel" het natrium blijft immers intra-cellulair en draagt niet bij aan de prikkel die zorgt dat het door de nieren wordt uitgescheiden. Freis wijst er overigens op dat het extra-cellulaire volume van alle "geciviliseerde" mensen enigermate vergroot is vanwege de doorgaans te hoge (hoger dan $50 \mathrm{mmol}$ per dag) natriumconsumptie ${ }^{104}$. Nog ongunstiger verloopt het hierboven beschreven proces wanneer er naast een teveel aan natrium tegelijk een relatief tekort aan kalium bestaat ${ }^{2,103,121,133}$. Een laag kalium remt de $\mathrm{Na} / \mathrm{K}$ pompfunctie en blokkeert daarmee de terugstroom van natriumionen van intra- naar extra-cellulair ${ }^{103,120}$. Daar komt nog bij, aldus Battarbee et al, dat genoemde invloed op de $\mathrm{Na} / \mathrm{K}$ pomp in de gladde spiercellen van de vaatwand nog sterker is dan in andere cellen ${ }^{48}$. Overigens tast men over de oorzaken van de stoornissen in het natrium/ kalium transport nog goeddeels in het duister $35,78,115,120,134,135,136$.

Een relatief tekort aan kalium uit zich voorts in een stimulering van de renineproduktie, hetgeen kan leiden tot vasoconstrictie ${ }^{97,103}$. Tenslotte wordt gemeld, dat een laag kaliumgehalte eveneens via inductie van prostaglandinevorming tot vasoconstrictie kan leiden ${ }^{103,137,138}$.

Omgekeerd geldt dat een, natuurlijke, hoge kaliuminneming een beschermende werking heeft op de beschreven gevolgen van een onnatuurlijke (te hoge) natriumconsumptie. Zo kan een kaliumrijke voeding zelfs tot natriurese leiden doordat de reninesecretie wordt geremd. Kalium zou daarnaast door rechtstreekse invloed op de bijnierschors de aldosteronafgifte stimuleren. Interessant is, dat aldosteron de natrium/ kalium-pomp werking lijkt te bevorderen. Door de toegenomen $\mathrm{Na} / \mathrm{K}$ ATP-ase activiteit in de endotheelcellen van de distale tubuli in de nieren neemt, ondanks de hogere aldosteron activiteit, de natriumexcretie toe. Overigens is voor het natriuretisch effect van kalium nog geen sluitende verklaring gevonden $103,115,121,123,139,140,141,142$.

Welke de genetische invloed is op dit complex van regelmechanismen is nog onvoldoende onderzocht. Dierexperimenteel onderzoek heeft het 
bestaan van een dergelijke genetische invloed duidelijk aangetoond. Tobian deed onderzoek waaruit bleek dat genetisch "ongevoelige" ratten geen hypertensie ontwikkelden bij een zoutopname die bij "gevoelige" ratten wèl hypertensie veroorzaakte. Bij deze laatste groep bestond een duidelijke dosis-effect relatie: hoe hoger de zoutconsumptie, hoe sterker de bloeddrukstijging. Toevoeging van kalium aan het rantsoen verminderde het natrium-effect op de bloeddruk wel, doch elimineerde dit niet geheel ${ }^{143,144}$. Zhao et al vonden - met name bij mannen, van wie beide ouders aan hypertensie leden - een positief verband tussen de hoogte van de bloeddruk en de hoogte van de intra-cellulaire natriumconcentraties in erythrocyten en leucocyten. $\mathrm{Zij}$ vonden een negatief verband met de $\mathrm{Na} / \mathrm{K}$ pomp activiteit. Bij personen van wie slechts één van beide ouders hypertensie had, waren de gevonden correlaties minder sterk ${ }^{145}$.

Ondanks alle onduidelijkheid omtrent de pathofysiologie die ten grondslag ligt aan het ontstaan van hypertensie, lijkt de hypothese gerechtvaardigd dat het minstens even belangrijk is dat de invloed van kalium (en waarschijnlijk ook die van calcium en magnesium) naast die van natrium in de beschouwingen omtrent voeding en hypertensie te betrekken. Het inzicht dat een relatief hoge kaliuminneming bij een natriumrijke voeding een positieve invloed heeft op het herstel van het osmotisch- en electrofysiologisch evenwicht, neemt toe $46,48,78,119,121$.

\subsubsection{Epidemiologische gegevens}

\subsubsection{Inleiding}

Reeds 2300 v.Chr. beweerden de Chinezen dat een harde pols het gevolg is van overmatig zoutgebruik. Zij propageerden derhalve een beperking van het gebruik van zout: de harde pols werd namelijk als voorbode van afasie gezien $^{\mathbb{4} 6}$.

Het mogelijke verband tussen de consumptie van grote hoeveelheden zout en het ontstaan van hypertensie heeft evenwel aanleiding gegeven tot vele discussies ${ }^{146,147,148,149,150,151,152,153,154}$. De belangrijkste reden hiervan is dat de talrijke onderzoekingen op dit terrein niet gelijk van opzet en bewijskracht zijn. Zo is bijvoorbeeld op populatieniveau in ecologische studies aangetoond dat hoge bloeddruk meer vóórkomt bij volkeren die veel zout gebruiken dan bij populaties die weinig zout consumeren. Op grond van dit gegeven wordt een samenhang verondersteld tussen de hoogte van het zoutgebruik en de hoogte van de bloeddruk. Een dergelijk verband is evenwel binnen populaties - op individueel niveau - niet overtuigend aangetoond. Een van de belangrijkste oorzaken hiervan is de sterke intra-individuele variabiliteit zowel in de bloeddruk als in de 
zoutconsumptie. Dat standaardisatie van meettechnieken in dezen gewenst is, spreekt woor zich. Tot dusverre laat deze standaardisatie echter veel te wensen over ${ }^{155}$. Dit laatste is overigens niet de enige reden dat de resultaten uit de vele internationale studies niet eensluidend zijn. Bij nadere beschouwing blijken namelijk vaak verschillende benaderingen te zijn gekozen om de zout-bloeddruk theorie kracht bij te zetten dan wel te ontzenuwen ${ }^{154}$. Vooral de operationalisering van de bloeddrukmeting en van de hoogte van de zoutconsumptie kan sterk verschillen. Zo zijn er enerzijds studies die een verband zoeken tussen de hoogte van de nagevraagde (of zelfs bekend veronderstelde) zoutconsumptie en de hoogte van bloeddruk ${ }^{104,156,157,158}$. Anderzijds wordt gezocht naar een samenhang tussen de hoogte van de natriumuitscheiding in de 24-uurs urine en het bloeddrukniveau $78,159,160,161$. Tenslotte wordt ook onderzoek beschreven naar het verband tussen de hoogte van de serum-electrolyten concentraties en het bloeddrukniveau ${ }^{35,155,162,163}$. Om tot valide uitkomsten voor de betreffende grootheden te komen, is evenwel geen eenvoudige opgave. Zo verschillen de meetmethoden ter vaststelling van de hoogte van de dagelijkse natrium-, kalium-, calcium- en magnesiuminneming onderling nogal. In paragraaf 2.2. is hier reeds op ingegaan. Daar is ondermeer gesteld dat voor het betrouwbaar vaststellen van de werkelijke hoogte van de individuele, dagelijkse natriuminneming 9 tot 14, 24-uurs urineverzamelingen zijn vereist.

Evenmin is het mogelijk de hoogte van de bloeddruk op grond van een eenmalige meting nauwkeurig vast te stellen. Het is vanwege fluctuaties noodzakelijk dat de bloeddruk enige malen wordt gemeten. De Gezondheidsraad formuleerde daarom criteria voor een optimale manier van bloeddrukmeting ${ }^{8}$. Daarnaast leveren een verkeerde meettechniek als een onjuiste daalsnelheid en foutieve aflezing (parallax) van de kwikkolom of een verkeerde afmeting en vorm van de bloeddrukmanchet even zovele foutenbronnen, welke de validiteit van de gevonden waarden kunnen reduceren ${ }^{8,164}$.

\subsubsection{Problemen bij interpretatie van epidemiologisch onderzoek als gevolg van verschil in onderzoeksopzet}

Niet alle vormen van epidemiologisch onderzoek hebben een even sterke bewijskracht. Hierboven zijn wij reeds gestoten op het verschil tussen onderzoekingen waarbij athankelijke en onafhankelijke variabelen op populatieniveau op een geaggregeerde manier zijn gemeten en met elkar in verband zijn gebracht en onderzoekingen waarbij deze metingen op individueel niveau zijn verricht. Een ander onderscheid is dat tussen experimenteel en observationeel onderzoek. De essentie van het verschil is gelegen in het feit dat bij experimenteel onderzoek door manipulatie 
van één variabele en constanthouding van alle overige variabelen de bewijskracht veel overtuigender is dan bij observationeel onderzoek. Hierbij moet de onderzoeker genoegen nemen met de situatie die hij vindt en beschikt niet over de mogelijkheid om met én of meer variabelen te manipuleren.

Zo wordt bij observationeel onderzoek alleen beschreven of "spontane" verschillen in de zoutconsumptie samen optreden met verschillen in de hoogte van de bloeddruk. Bij experimenteel onderzoek grijpt de onderzoeker daarentegen in: met de hoogte van de zoutconsumptie wordt geëxperimenteerd teneinde het bloeddrukniveau te beinvloeden.

Het zal ook duidelijk zijn dat bij observationeel onderzoek rekening moet worden gehouden met bias en confounding. Bias ontstaat ten gevolge van fouten en tekortkomingen in de onderzoeksopzet of gegevenswerzameling. Men onderscheidt enerzijds de zogenaamde selectiebias, vertekening door selectie mechanismen, die de samenstelling van de met elkaar te vergelijken onderzoeksgroepen beïnvloedt. Anderzijds spreekt men van informatie-bias indien verschillen ontstaan door de wijze van gegevensverzameling ${ }^{38}$. Voorts kunmen verstorende variabelen (confounding) het trekken van conclusies uit onderzoek naar de geldigheid van de zout-bloeddrukhypothese bemoeilijken ${ }^{78,158}$. Men denke aan de invloed van leeftijd en geslacht bij de bloeddrukregulatie. Onderzoekspopulaties zijn niet altijd aan elkaar gelijk op deze punten. Ook genetische predispositie voor het ontstaan van hypertensie is als risicofactor van belang evenals obesitas $8,82,65,165$. De genetische predispositie in de vorm van een positieve familie anamnese is niet altijd bekend. In nagenoeg alle epidemiologische studies wordt een sterk positieve relatie gevonden tussen het lichaamsgewicht en de hoogte van de bloed-

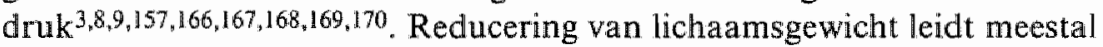
tot een daling van de bloeddruk, onafhankelijk van de zoutconsumptie $29,171,172$. In elk onderzoek zal dus het lichaamsgewicht mede moeten worden betrokken.

Bovendien speelt ook een zeker saturatie-effect een rol46,48. Hiermee wordt op de situatie gedoeld dat de gehele bevolking een zodanig hoge natriuminneming heeft, dat alle daarvoor (genetisch) gevoeligen hypertensie zullen ontwikkelen. Vergelijkend onderzoek binnen één populatie naar de tijd-respons en de dosis-respons relatie zal in die situatie nauwelijks bruikbare resultaten opleveren. Overigens kan dit laatste ook belemmerd worden door het gegeven dat de éen wel en de ander niet gevoelig is voor de specifieke invloed van zout ${ }^{49} 9_{i} 173$.

De discussie omtrent een oorzakelijk verband tussen de zoutconsumptie en de bloeddruk wordt voorts in niet geringe mate gecompliceerd door het feit, dat niet alleen natrium voor de bloeddruk- 
regulering van belang is. De laatste jaren groeit meer en meer het inzicht, dat ook andere mineralen als kalium, calcium en magnesium van betekenis zijn bij de fysiologische bloeddrukregulatie (zie paragraaf 2.3.1.).

Tevens kan ook alcoholgebruik de bloeddrukregulering beïnwloeden en aldus als verstorende variabele van belang zijn 174,175,176,177. Ook de dagelijkse vetconsumptie - zowel de hoeveelheid als de soort vet - lijkt, onafhankelijk van de energie- en natriuminneming, de hoogte van de bloeddruk te kunnen beinwloeden ${ }^{178}$.

Observationeel onderzoek wordt in drie hoofdvormen onderverdeeld ${ }^{38}$.

- Dwarsdoorsnede-onderzoek (ook wel cross-sectioneel of transversaal onderzoek genoemd): hierbij wordt in de onderhavige problematiek de mate van zoutgebruik en het niveau van de bloeddruk bij eenzelfde individu op eenzelfde moment in de tijd gemeten.

- In het zogenaamde patiënt-controle onderzoek wordt een vergelijking gemaakt tussen personen met en zonder hypertensie. Vervolgens wordt retrospectief (longitudinaal) nagegaan of de veronderstelde causale factor - de hoogte van het zoutgebruik - in de anamnese van personen met hypertensie verschilt van personen zonder hoge bloeddruk (controle personen). Patiënt-controle onderzoek kan worden verricht op basis van prevalente en incidente ziektegevallen. Zowel bij het dwarsdoorsnede-onderzoek als bij het patiënt-controle onderzoek bestaat een reëel gevaar voor selectie-bias. Immers twee groepen die door selectiemechanismen niet echt aan elkaar gelijk zijn, mogen niet met elkaar worden vergeleken. Het gevaar voor informatie-bias bestaat vooral bij het patient-controle onderzoek. Bias kan veelal worden voorkómen door te kiezen voor een zogenaamde blinde onderzoeksopzet. De onderzoeker noch de deelnemer weten hierbij wie tot de patiëntengroep en wie tot de controlegroep behoort.

- Bij de laatste vorm van observationeel onderzoek, het cohort-onderzoek wordt - in tegenstelling tot het patiènt-controle onderzoek - juist uitgegaan van groepen personen die wel en die niet, dan well in verschillende mate aan de hypothetische, causale oorzaak geexponeerd zijn of zijn geweest. Onderzocht wordt of personen die een hoog zoutgebruik hebben of hebben gehad, vaker hypertensie ontwikkelen dan een controlegroep, die niet aan hoog zoutgebruik is blootgesteld (geweest). Dan wel of er een relatie is tussen zoutgebruik nu en de hoogte van de bloeddruk na een aantal jaren. Een cohort-onderzoek kan zowel prospectief als retrospectief van opzet zijn.

Informatie-bias is - evenals bij het patiënt-controle onderzoek - te 
voorkőmen door de gegevens omtrent de aandoening en de expositie "blind" te verzamelen.

Indien de centrale vraagstelling is "leidt een hoog zoutgebruik tot verhoogde bloeddruk?" dan is duidelijk dat observationeel onderzoek slechts een beperkte etiologische bewijskracht heeft. Immers de methodiek, die nodig is om valide gegevens te werkrijgen omtrent de hoogte van het individuele zoutgebruik en van de bloedddruk limiteren de waarde van het dwarsdoorsnede-, het patiënt-controle en zelfs van het cohortonderzoek als hypothese-toetsende procedure. Wel dragen zij meer of minder bij aan de hypothese-vorming. Herhaalde uitgangsmetingen zouden hier een belangrijke bijdrage kunnen leveren doch dit wordt om praktische redenen zelden toegepast. Tevens dient te worden bedacht dat confounding - de inwerking van verstorende variabelen - van betekenis kan zijn. Matchen, stratificeren en multivariate analyse zijn technieken om de invloed van bekende of vermeende verstorende variabelen te minimaliseren. Onbekende en dus niet in de opzet verwerkte variabelen kunnen evenwel steeds als confounder blijven optreden en zo een in werkelijkheid niet bestaande associatie suggereren dan wel een reëel aanwezig verband maskeren of juist versterken ${ }^{38}$.

In de geindustrialiseerde landen is vrijwel de gehele bevolking geëxponeerd aan een voeding met een hoog natriumgehalte. Door het geringe onderscheid in zoutgebruik tussen verschillende individuen in de bevolking zijn het patiënt-controle en het cohort onderzoek nauwelijks zinvol. Het relatieve risico en het daarmee samenhangende populatie-attributieve risico voor geëxponeerden alsmede het attributieve risico voor de populatie van hoog zoutgebruik voor het ontstaan van hypertensie zijn derhalve niet eenvoudig te berekenen. Voor deze berekening dient immers een vergelijking te worden gemaakt tussen geëxponeerden en niet-geëxponeerden ${ }^{38}$.

Experimenteel interventic onderzoek is - in het algemeen - beter geschikt om hypothesen te toetsen. Indien het verband tussen zoutgebruik en bloeddrukhoogte sterk, plausibel en consistent lijkt dan mag een causale relatie worden vermoed en kan experimenteel onderzoek worden opgezet.

$\mathrm{Na}$ allocatie van de onderzoekspopulatie aan twee of meer behandelingsgroepen, impliceert het experiment: behandeling, manipulatie of interventie door de onderzoeker. Met behulp van randomisatie wordt getracht de experimentele- en de controle-groep in zoveel mogelijk kenmerken vergelijkbaar te houden. Op deze wijze wordt selectie-bias voorkómen. Desgewenst kan vooraf stratificatie in subgroepen (bijwoorbeeld naar leeftijd en geslacht) plaatsvinden. Tevens kan randomisatie 
geschieden op basis van individuen. In een gekruist opgezet experimenteel onderzoek, krijgt elke proefpersoon de te onderzoeken "behandelingen" na elkaar en fungeert zo tevens als controlepersoon. In een dubbelblind onderzoek zijn noch de proefpersoon, noch de onderzoeker op de hoogte van de werkelijke aard van de behandeling. Het is duidelijk dat slechts met één variabele tegelijk gemanipuleerd mag worden en dat bij voedingsexperimenten aan de dubbelblinde eis moeilijk kan worden voldaan ${ }^{38}$.

Inzake zout en bloeddruk berusten de experimenten veelal op het reduceren van natrium in de woeding. In geval wan onderzoek naar de invloed van kalium, wordt juist extra kalium toegevoegd. Ook is niet uit te sluiten dat door chronisch hoog zoutgebruik mogelijk irreversibele pathofysiologische veranderingen in het menselijk lichaam zijn veroorzaakt , die de waarde van - doorgaans kortdurend - experimenteel onderzoek reduceren. Een additioneel probleem is dat het niet altijd mogelijk blijkt experimentele- en controlegroepen via randomisatie te vormen. Men denke hierbij - vooral bij grootschalig experimenteel onderzoek - aan economische, praktische of medisch-ethische motieven. Ook kan het randomisatie-effect verloren gaan, bijwoorbeeld als de aard van het experiment bekend wordt. In die situatie wordt vaak gebruik gemaakt van zogenaamde voor/na vergelijkingen ${ }^{38}$.

Samenvattend: tengevolge van de grote intra-individuele variabiliteit in de hoogte van de dagelijkse zoutconsumptie en de incidentele bloeddrukmetingen enerzijds en anderzijds de talloze verstorende variabelen die op deze relatie inwerken, dient middels een combinatie van observationeel en experimenteel onderzoek een sluitend bewijs voor de zoutbloeddrukhypothese te worden geleverd. Interacties tussen de diverse factoren dienen onderscheiden te worden bij de beoordeling van de resultaten van epidemiologisch onderzoek.

In het navolgende wordt een overzicht gegeven van een aantal epidemiologische onderzoekingen op dit gebied met als doel te illustreren hoe gecompliceerd de etiologische bewijsvoering is en hoever deze gevorderd is.

\subsubsection{Natrium}

Verreweg het grootste aantal onderzoeken is gericht geweest op de invloed van natrium op de bloeddruk. Daarbij overheersen de observationele studies. Een van de meest consistente argumenten vóór een positieve relatie tussen keukenzoutgebruik en bloeddruk vormen de bevindingen uit vergelijkend onderzoek tussen verschillende populaties. Bij volkeren, die zeer weinig natrium gebruiken, komt vrijwel geen 
hypertensie voor. Opmerkelijk is, dat de bloeddruk bij die bevolkingen met het klimmen der jaren niet of nauwelijks stijgt ${ }^{166,179}$. Zulks blijkt bijvoorbeeld wit het onderzoek van Oliver onder de Yanomano indianen, van Truswell onder de bosjesmannen, van Page onder de bewoners van de Solomon eilanden en van Prior in Polynesië, $966,180,181$. Het is duidelijk, dat het nauwkeurig verzamelen van de benodigde gegevens onder deze omstandigheden niet eenvoudig is. Omgekeerd blijkt, dat onder volkeren die veel zout gebruiken, frequent hypertensie voorkomt. Bij hen is het stijgen van de bloeddruk met de leeftijd een bekend verschijnsel. De meest sprekende voorbeelden komen uit Japan. In Noord-Japan, waar gemiddeld $450 \mathrm{mmol}$ natrium (overeenkomend met $26 \mathrm{~g}$ keukenzout) per dag wordt ingenomen, heeft $38 \%$ van de volwassen bevolking, volgens de WHO-criteria hypertensie $3,104,156$. In Zuid-Japan, waar het natriumgebruik omstreeks $225 \mathrm{mmol}$ per dag bedraagt, is de prevalentie van hypertensie omgeveer $21 \%{ }^{104,156}$. In de V.S. en in Europa lijdt 10-15\% van de bevolking aan hypertensie. De gemiddelde natriuminneming ligt daar tussen de 100 en $200 \mathrm{mmol}$ per dag ${ }^{3,57}$. Men dient zich te realiseren, dat deze waarden onafhankelijk van elkaar zijn gemeten. Vanzelfsprekend moet men het resultaat van vergelijkingen tussen populaties met voorzichtigheid duiden. Behalve de zoutconsumptie zijn er immers tal van andere variabelen die verschillen in bloeddruk kunnen veroorzaken $^{147,148, ~} 149$. Niettemin ondersteunen bovenstaande correlatiestudies de hypothese dat er een oorzakelijk verband kan bestaan tussen de hoogte van de consumptie van keukenzout en de hoogte van de bloeddruk ${ }^{182}$. Hoewel hiernaar over de gehele wereld onderzoek is verricht, is dit verband voor individuen binnen een bevolking nog onvoldoende aangetoond ${ }^{154}$. Illustratief is in dit verband het dwarsdoorsnede onderzoek van Komachi et al, die verschillende bevolkingsgroepen in Japan vergeleken ${ }^{183}$. Zowel de prevalentie van hypertensie als de hoogte van het zoutgebruik bleken onder plattelanders aanzienlijk hoger dan onder stedelingen. De traditionele Japanse voeding, zoals die door de plattelandsbewoners wordt gebruikt, bevat veel meer natrium dan de voeding van de stedelingen. Soortgelijke uitkomsten vonden Sasaki en Sever et al ${ }^{67,184}$. Genoemde auteurs gaven een nauwkeurige beschrijving wan de onderzoekspopulatie naar leeftijd en geslacht. Tevens werd obesitas als verstorende factor in de beoordeling betrokken. De voedingsgegevens werden in het Japanse onderzoek van Sasaki op anamnestische wijze verkregen. Sever daaremtegen heeft de natriumexcretie in de 24-uurs urine gemeten onder stammen in Zuid Afrika. Geen van de auteurs vond echter een individuele samenhang. Met andere woorden: binnen de onderscheiden subpopulaties kon op individueel niveau geen verband tussen de zoutconsumptie en de bloeddruk worden vastgesteld. Het een en ander 
houdt mogelijk verband met de sterke intra-individuele variabiliteit in de hoogte van de genoemde parameters. Zowel voedingsanamnestisch onderzoek als een éénmalige 24-uurs urineverzameling zijn in dezen principieel ontoereikend (zie paragraaf 2.2.).

Ook Schlierf et al, die in de "Heidelberg Study" 800 mannen van 20 tot 40 jaar onderzochten, konden geen verband aantonen tussen de zoutexcretie in de 24-uurs urine en de bloeddruk ${ }^{160}$. Van $48 \%$ van de onderzoekspopulatie werd in dit transversale onderzoek éénmaal de natriumexcretie bepaald. Hoewel $14 \%$ van de deelnemers aan hypertensie leed en de gemiddelde natriumexcretie hoog was, kon geen significante relatie tussen natriumuitscheiding en bloeddruk worden gevonden. Ook hier lijkt de binnenpersoonsvariatie van bloeddruk en natriumuitscheiding de verklaring.

In het Nieuwzeelands onderzoek "The Milton Survey" werd door Simpson et al geen verband gevonden tussen de natriumexcretie in de 24-uurs urine en de bloeddrukhoogte ${ }^{185,186,187}$. Het betrof hier een transversale populatiestudie waarbij in diverse leeftijdscategorieën per geslacht gezocht is naar het genoemde verband. Stapsgewijze regressieanalyse, waardoor de invloed van mogelijke verstorende variabelen (waaronder het lichaamsgewicht) op de bloeddruk werd geëlimineerd, bracht evenmin een relatie aan het licht.

Afwezigheid van een relatie tussen bloeddruk en zoutgebruik voor individuen was ook het resultaat van onderzoekingen met een overeenkomstige studie-opzet. Zo leverden de verschillende onderzoekingen, die in de afgelopen jaren in Finland door Tanskanen ${ }^{78}$, Tuomilehto et all ${ }^{159}$ en Karvonen et al ${ }^{188}$ zijn verricht, geen andere uitkomsten op. Ook het onderzoek van Staessen en medewerkers in België wierp geen ander licht op deze zaak ${ }^{189}$. Deze laatsten stelden duidelijk, dat de hoogte van de natriumuitscheiding in een éénmalige 24-uurs urineverzameling onvoldoende informatie werschaft over het voorafgaande zoutgebruik door een individueel persoon. Ook in de bekende Framingham Heart Study - een longitudinaal onderzoek - kon geen verband worden aangetoond tussen zoutgebruik en bloeddruk 157,158 . In dit groots opgezette, langlopende prospectieve cohort-onderzoek werd onder andere de invloed van de zoutconsumptie op het ontstaan van hypertensie bestudeerd. Naast voedingsanamnestisch onderzoek ter bepaling van de hoeveelheid aan tafel toegevoegd keukenzout, werd van een beperkt aantal deelnemers de 24-uurs urine verzameld. Noch tussen beide bepalingen, noch tussen de urinewaarden en de bloeddrukhoogte werd een verband gevonden. Dit sluit aan bij het in paragraaf 2.3.2.2. gestelde betreffende observationele studies.

Het aantal observationele onderzoeken waarin de relatie tussen bloed- 
druk en zoutgebruik wèl werd waargenomen, is zeer gering. Het betreft vooral de dwarsdoorsnede studies van Kesteloot et al in België en Korea ${ }^{68,163,190}$ en die van Joossens et al in België ${ }^{191 .}$

In de Koreaanse studie werd een positief verband gevonden tussen de hoogte van de natriumuitscheiding en de hoogte van de bloeddruk. Voor leeftijd, geslacht en lichaamsgewicht werd gecorrigeerd. De 24-uurs urine werd op drie achtereenvolgende dagen verzameld. Een op analoge wijze uitgevoerd onderzoek in België toonde echter een dergelijk verband niet aan $^{190}$. De auteur wijt dit verschil tussen beide studies aan de lage kaliuminneming in Korea $68,163,190$. Ander Belgisch onderzoek werd verricht onder een groot aantal volwassenen. Na correctie voor onder andere leeftijd en geslacht alsmede lichaamslengte en -gewicht, bleef een kleine maar significante positieve correlatie bestaan tussen de natriumexcretie in de 24-uurs urine en bloeddrukhoogte. Bij deze studie werd van iedere deelnemer 10 maal de 24 -uurs urine verzameld ${ }^{191}$ "De opmerkelijke resultaten uit deze transversale onderzoekingen, zijn waarschijnlijk vooral te verklaren uit het frequent meten van zowel de bloeddruk als de 24-uurs urine.

Ook het onderzoek van Ten Berge-Van der Schaaf die schoolkinderen in Haren en Slochteren onderzocht, liet zo'n verband zien, zij het uitsluitend voor de jongens van wie de moeders een diastolische bloeddruk hadden van $90 \mathrm{~mm} \mathrm{Hg}$ of meer ${ }^{192}$. De 24-uurs urine werd in dit transversale onderzoek slechts één maal verzameld, de bloeddruk werd op drie achtereenvolgende dagen 2 maal gemeten.

Aparte vermelding verdient tenslotte het onderzoek van Shaper et al ${ }^{165}$. $\mathrm{Zij}$ deden een retrospectief cohortonderzoek onder Samburu's in NoordKenia. Het bleek, dat jonge mannen die dienst namen in het Keniaanse leger in groten getale hypertensie ontwikkelden - een aandoening die onder de overige leden van de stam nauwelijks voorkomt. De auteurs zoeken de verklaring voor dit verschijnsel in het feit, dat de recruten na indiensttreding overschakelden van een voeding met gemiddeld 2 tot 3 gram zout naar een met circa 16 gram zout per dag.

Naast de hierbovengenoemde observationele studies, is met name de laatste tijd ook experimenteel- of interventieonderzoek verricht. Daarbij betrof het sllechts in enkele gevallen "gezonde" proefpersonen d.w.z. personen met een normale bloeddruk. Een van deze onderzoeken werd beschreven door Brunstyn et al. Zij gaven gezonde vrijwilligers extra natrium in de vorm van "Slow Sodium" tabletten maar konden daarmee geen bloeddrukstigging bewerkstelligen ${ }^{193}$. Getracht werd de overige variabelen in dit dubbelblind, gerandomiseerd, gekruist opgezette onderzoek constant te houden. Overigens duurde dit experiment slechts enkele weken en kwam het natrium supplement boven op het reeds in de voeding 
aanwezige natrium. Heel opmerkelijk is het onderzoek dat Hofman et al bij zuigelingen verrichtten ${ }^{194,195}$. Zij vergeleken de bloeddruk van zuigelingen, die wanaf de geboorte een natrumarme kunstwoeding kregen met die van zuigelingen die een "normale" kunstvoeding gebruikten. Het bleek dat de bloeddruk van eerstgenoemden na een half jaar significant lager was dan die van de controlegroep. In dit onderzoek werd de molaire natrium/kalium ratio van beide typen voedingen constant gehouden. Derhalve is ook het kaliumgehalte van de natriumarme voeding lager dan van de normale voeding. Mogelijk was het resultaat van het onderzoek nog overtuigender geweest, indien alleen het natriumgehalte van de experimentele voeding veranderd was en derhalve de $\mathrm{Na} / \mathrm{K}$ ratio eveneens was verlaagd.

Veel groter is het aantal onderzoeken dat bij hypertensiepatiënten is verricht. In de meeste gevallen stelden de onderzoekers zich de vraag of natriumbeperking in de dagelijkse voeding tot tensiedaling zal leiden. Richards et al deden een dubbelblind, gerandomiseerd, gekruist opgezet interventieonderzoek waaraan twaalf patienten deelnamen ${ }^{196}$. Onbehandeld varieerde hun bloeddruk tussen $140 / 90$ en $180 / 105 \mathrm{~mm} \mathrm{Hg}$. Vergeleken werd het effect van een natriumbeperkt dieet $(80 \mathrm{mmol}$ natrium) en een controle dieet ( $180 \mathrm{mmol}$ natrium per dag). $\mathrm{Na}$ vier weken werd in geen van beide groepen een statistisch significante bloeddrukdaling waargenomen. Met behulp van variantie-analyse werd voor de diverse variabelen gecorrigeerd. Het lichaamsgewicht van de deelnemers bleef gedurende de onderzoeksperiode constant. De duur van de studie lijkt evenwel te kort voor het verkrijgen van valide resultaten.

Watt et al bestudeerden de bloeddrukverlagende werking van zoutbeperking bij 18 hypertensiepatiënten in een huisartspraktijk ${ }^{197}$. Ook hun onderzoek dat dubbelblind, gerandomiseerd, gekruist was opgezet, leverde niet het verwachte resultaat op. Het lichaamsgewicht van de deelnemers bleef gedurende de onderzoeksperiode van slechts acht weken nagenoeg constant. Er werden geen pogingen ondernomen de energieopneming en de kaliuminneming te beïnvloeden. Voor effecten van diverse variabelen die het eindresultaat zouden kunnen beinvloeden, werd gecorrigeerd.

Bing et al poogden enig ondersteunend effect van natriumbeperking op de medicamenteuze therapie aan te tonen, maar dit lukte niet ${ }^{198}$. Hunt et all slaagden hier wel in ${ }^{98}$. $\mathrm{Zij}$ vervolgden 3.000 hypertensiepatiènten met een natriumbeperkt dieet gedurende vijf jaren. Het gebruik van antihypertensiva daalde. Opgemerkt moet worden, dat het lichaamsgewicht van de deelnemers eveneens significant daalde, hetgeen op zich een verklaring kan leveren voor bloeddrukdaling en het verminderd antihypertensivagebruik. Ook Beard et al toonden overtuigend aan dat het 
geneesmiddelengebruik door 90 hypertensiepatiënten drastisch kon worden gereduceerd onder invloed van een natrumbeperkte voeding ${ }^{19}$. De natriumuitscheiding in de 24-uurs urine bedroeg bij de dieetgroep gemiddeld $37 \pm 22$ en bij de controlegroep $161 \pm 62 \mathrm{mmol}$. Bij dit onderzoek daalde behalve de natriumuitscheiding ook het lichaamsgewicht van de deelnemers significant. Dit laatste beinvloedde de conclusies van het onderzoek echter niet, aldus de auteurs. Over de hoogte van de kaliumuitscheiding wordt geen informatie vermeld. Deze dubbelblind, gerandomiseerd maar niet gekruist opgezette studie duurde 12 weken.

Morgan et al vonden in twee interventiestudies dat zoutbeperking in de voeding van hypertensiepatiënten met diastolische waarden van 95 tot $105 \mathrm{~mm} \mathrm{Hg}$ een daling van de bloeddruk teweeg bracht ${ }^{199,200,201}$. Bij een reductie tot $70-100 \mathrm{mmol}$ natrium per dag, werd een diastolische bloeddrukdaling van ruim $7 \mathrm{~mm} \mathrm{Hg}$ bereikt. Uit de beschrijving van deze twee jaar durende studie blijkt niet of het lichaamsgewicht van de deelnemers gelijk bleef. Ook werd geen poging ondernomen de invloed van verstorende variabelen te elimineren. Tenslotte is het vermeldenswaard dat niet van alle deelnemers de 24 -uurs urine is verzameld, zodat de controle op de nalleving van het natriumbeperkte dieet onvolledig kan worden genoemd.

Eerder dan door Morgan en zijn medewerkers waren soortgelijke bevindingen al door Parijs et al gedaan in een dubbelblind, gerandomiseerd, gekruist opgezet onderzoek ${ }^{202}$. Zij vonden dat een daling in natriuminneming van 191 naar $93 \mathrm{mmol}$ per dag resulteerde in een bloeddrukdaling van gemiddeld $10 \mathrm{~mm} \mathrm{Hg}$ systolisch en $5 \mathrm{~mm} \mathrm{Hg}$ diastolisch. In deze studie bleef het lichaamsgewicht van de deelnemers nagenoeg gelijk. De auteurs stellen overigens zelf dat het effect van de verandering van de natriuminneming op de bloeddrukhoogte van patiënt tot patiënt varieert. Toepassing van multivariate variantieanalyse had wellicht meer duidelijkheid in de oorzaken hiervan kunnen brengen.

Als woorbeeld van een fraai opgezet dubbelblind, gerandomiseerd, gekruist onderzoek geldt de studie van MacGregor et al ${ }^{161}$. Deze studie laat niet alleen zien dat onder invloed van effectieve dieetmaatregelen (de natriumexcretie in de 24-uurs urine zakte van 191 naar $83 \mathrm{mmol}$ ) de bloeddruk significant daalde. Na herstel van het oorspronkelijke voedingspatroon bleek deze weer geleidelijk op te lopen. De overige variabelen werden constant gehouden. De 24-uurs wrine werd op zes verschillende tijdstippen verdeeld over twee dagen verzameld.

Langford et al deden onderzoek bij personen die onder invloed van anti-hypertensieve medicatie een normale bloeddruk vertoonden ${ }^{203}$. $\mathrm{Na}$ stopzetting van de medicatie werden twee groepen gevormd: de ene met natriumbeperkende voedingsmaatregelen $(70 \mathrm{mmol} / 24 \mathrm{uur})$ de andere 
groep met een gereduceerde calorie-opname. Na ruim één jaar bleek $50 \%$ van de studiepopulatie zonder medicatie doch met een natriumbeperkte of calorie-arme voeding een normale bloeddruk te behouden. Dit enkelvoudig blind, gerandomiseerd, gekruist opgezet onderzoek werd overigens wel bij een selecte groep uitgevoerd, namelijk personen die reeds wijf jaar een anti-hypertensiekliniek bezochten ${ }^{204}$. De nul-waarden voor natriumexcretie in de 24-uurs urine waren dan ook reeds betrekkelijk laag: $153 \mathrm{mmol}$ bij adipeuze deelnemers, $131 \mathrm{mmol}$ bij personen met een normaal gewicht. Belangrijk is dat de hoogte van het kalium niet in de beoordeling van de resultaten is meegenomen, terwijl de interventie een voeding opleverde die niet alleen slechts 70 mmol natrium doch eveneens $100 \mathrm{mmol}$ kalium bevatte.

\subsubsection{Kalium}

Zoals uit paragraaf 2.3.1. blijkt, kan de rol van natrium in het kader van de pathofysiologie van de bloeddrukregulatie niet los worden gezien van die wan kalium. Het mag dan ook opmerkelijk heten, dat naar het verband tussen het kaliumgebruik en de hoogte van de bloeddruk betrekkelijk weinig onderzoek is verricht. Op populatieniveau is komen vast te staan dat wolkeren die veel natrium in hun voeding hebben, veelal weinig kalium gebruiken, terwijl volkeren die weinig natrium gebruiken daarentegen doorgaans kaliumrijk voedsel kennen. Het is, gezien het voorafgaande niet uitgesloten dat een hoog kaliumgehalte in de voeding een gunstige invloed op de tensie zal kunnen uitoefenen.

Evenmin als dat voor natrium het geval was, blijkt het voor kalium eenvoudig op individueel niveau met behulp van observationele studie relaties te leggen met de bloeddruk. Zo konden Fodor et al in een transwersaal onderzoek geen verband vinden tussen kaliuminneming en de hoogte van de bloeddruk ${ }^{205}$. Toch was de prevalentie van hypertensie hoog (20-30\%) en de kaliuminneming laag (37-44 mmol per dag). In dit onderzoek is geen gebruik gemaakt van de 24-uurs urine ter bepaling van de hoogte van de kaliuminneming maar van de dubbel-portie methode. Op de waarde hiervan is in paragraaf 2.2 . reeds ingegaan.

Ook Tuomilehto et al konden een dergelijke relatie niet aantonen ${ }^{159}$. $\mathrm{Zij}$ verrichtten dwarsdoorsnede-onderzoek onder hypertensiepatiënten en personen met een normale bloeddruk. Daarentegen vonden Staessen et al in een transversaal onderzoek een negatieve correlatie tussen de dagelijkse kaliumuitscheiding in de 24-uurs urine en de systolische bloeddruk bij mannelijke deelnemers ${ }^{189}$. Tanskanen kwam in Finland tot soortgelijke bevindingen ${ }^{78}$. Hij nam in een grootschalig dwarsdoorsnedeonderzoek bij de groep mannelijke deelnemers een negatieve correlatie waar tussen de kaliumuitscheiding in de 24 -uurs urine en het bloeddruk- 
niveau. Opmerkelijk was dat onder de vrouwelijke deelnemers juist een positief verband werd gevonden. De auteurs hebben hier.geen verklaring voor. In dit onderzoek werd de invloed van verstorende variabelen op de bloeddruk met variantie-analyse nagegaan en geëlimineerd.

Recent publiceerden Kromhout et al de resultaten van een prospectief cohort-onderzoek onder mannen van oorspronkelijk middelbare leeftijd uit Zutphen ${ }^{206}$. Zij vonden dat de gemiddelde kaliuminneming in 1960: \pm $130 \mathrm{mmol} / \mathrm{dag}$, in $1965: \pm 110 \mathrm{mmol} / \mathrm{dag}$ en in $1970: \pm 102 \mathrm{mmol} / \mathrm{dag}$ bedroeg. Na correctie voor calciuminneming, alcoholgebruik, energieopname, Quetelet-index en leeftijd bleek verandering in de kaliuminneming negatief te correleren met de systolische bloeddrukstijging. In dit onderzoek werd de kaliuminneming geschat via voor dit doel minder geschikt voedingsanamnestisch onderzoek en niet met behulp van de 24-uurs urine. Kesteloot vond in de eerder beschreven Koreaanse studie een negatieve correlatie tussen bloeddrukhoogte en kaliuminneming 163,190 .

De veronderstelling dat kalium een gunstige invloed uitoefent op de bloeddruk, heeft ertoe geleid dat er diverse experimentele interventie onderzoeken op dit terrein werden verricht. Khaw et al dienden in een dubbelblind, gerandomiseerd, gekruist opgezet onderzoek, aan twintig gezonde jonge mannen gedurende twee weken acht tabletten Slow Kalium (64 mmol kalium totaal) per dag toe ${ }^{207}$. Dit bracht een statistisch significante daling van de bloeddruk met zich mee. De 24-uurs urine werd in iedere onderzoeksfase twee maal verzameld. Burnstyn et al, die eveneens Slow Kalium tabletten toedienden aan gezonde proefpersonen, vonden daarentegen geen verlaging van de bloeddruk ${ }^{193}$. Holy et al melden op grond van een studie van gelijke opzet eveneens een dergelijke bevinding $208_{2} 2092_{2} 210,211$. Wel namen zij waar dat toediening van kalium aan hypertensiepatiënten een gunstig effect had op de bloeddruk. Overeenkomstige resulltaten vonden Skrabal et al, die onderzoek verrichtten bij proefpersonen met een familiaire belasting voor hypertensie. De auteurs vermelden vier aangrijpingspunten voor het kaliumeffect: een vermindering van het extra-cellulaire volume, een verbetering van de baroreceptorfunctie, een uitblijven van de stijging van de noradrenalinespiegel en tenslotte een goede acceptatie van een natriumbeperkt dieet na toevoeging van kalium. Het is de vraag of de in dit onderzoek gebruikte t-toets en Wilcoxon rangcorrelatie toets toereikend zijn om de mogelijke interacties tussen bovengenoemde effecten te onderkennen ${ }^{212}$.

MacGregor et al dienden 23 patiënten met lichte hypertensie gedurende vier weken acht Slow Kalium tabletten per dag toe ${ }^{140}$. Hoewel de patiënten geen natriumbeperkt dieet volgden, daalde de bloeddruk in dit dubbelblind, gerandomiseerd, gekruist onderzoek siginificant. Tijdens de toediening van kalium nam de natriumexcretie in de 24-uurs urine toe. 
Op dit laatste is in paragraaf 2.3 .1 . reeds gewezen als mogelijk verklarend voor kalium. Richards et al vonden in het eerder beschreven onderzoek, rekening houdend met verstorende variabelen, geen bloeddrukdaling tijdens de toediening van extra kalium ${ }^{196}$.

\subsubsection{Molaire natrium/kalium ratio}

Volgens sommige auteurs is het denkbaar, dat niet zozeer de absolute hoogte van de natrium- respectievelijk kaliuminneming van invloed op de bloeddruk is, als wel de kwantitatieve verhouding tussen beide mineralen ${ }^{36,37}$. Vandaar, dat een aantal onderzoekers deze waarde afzonderlijk in zijn studies heeft betrokken. Het verhoudingsgeta in landen waar frequent hypertensie voorkomt, is veel hoger dan in landen waar hypertensie zeldzaam is. Evenals bij het verband tussen natrium-dan wel kaliuminneming enerzijds en bloeddruk anderzijds geld took hier, dat de individuele correlatie met de bloeddruk niet eenvoudig is vast te stellen ${ }^{159,213}$. Vermelding verdient het al eerder genoemde experimenteel interventie onderzoek van Khaw et al. De bloeddruk van de gezonde proefpersonen, die een normaal westers voedingspatroon volgden, daalde door toevoeging van kalium. Aangezien de verandering van de molaire $\mathrm{Na} / \mathrm{K}$ ratio positief correleerde met de tensieverandering, zou niet alleen de directe invloed van kalium op de bloeddrukregulatie maar ook de indirecte werking via de $\mathrm{Na} / \mathrm{K}$ ratio zijn aangetoond ${ }^{20 \%}$.

Page et al bestudeerden in een observationeel, dwarsdoorsnede-onderzoek de voedingsgewoonten onder de Qash'qai nomaden in Iran ${ }^{213}$. Zij vonden een positieve correlatie tussen de $\mathrm{Na} / \mathrm{K}$ ratio en de systolische bloeddruk bij de vrouwelijke deelnemers. De onderzoekers gebruikten de ochtendurine voor de bepaling van de $\mathrm{Na} / \mathrm{K}$ ratio, hetgeen de betekenis van de uitkomsten reduceert. Kesteloot voerde een transversaal onderzoek onder mannen uit in het Belgische leger. Multivariate variantieanalyse leverde evenwel een negatieve correlatie op tussen de uit de 24uurs urine berekende molaire natrium/kalium ratio en de systolische en diastolische bloeddruk ${ }^{163}$. De auteur heeft geen afdoende verklaring voor deze bevinding.

\subsubsection{Andere mineralen}

Natrium en kalium zijn vermoedelijk niet de enige mineralen die van invloed zijn op bloeddrukregulatie. Dat ook andere ionen een rol zouden kunnen spelen is onder meer naar voren gekomen uit het bekende transversale Amerikaanse HANES onderzoek ${ }^{124,214}$. Hierbij werd gevonden dat hypertensiepatiënten $18 \%$ minder calcium innamen dan mensen met een normale bloeddruk. 
Kesteloot et al maakten in breed opgezet transversaal onderzoek daarentegen juist melding van een positieve correlatie tussen de 24-uurs calciumuitscheiding in de urine en de bloeddruk ${ }^{155,162}$. Deze bevindingen worden overigens niet bevestigd door de eerder beschreven onderzoekingen van Joossens et $\mathrm{a}^{81}$ en Fodor et $\mathrm{al}^{205}$. In beide laatstgenoemde studies is gebruik gemaakt van woedingsanamnestisch onderzoek, hetgeen in het algemeen een goede weerspiegeling geeft van het dagelijkse calciumgebruik (zie paragraaf 2.2.). Ook in het HANES onderzoek is gebruik gemaakt van voedingsanamnestische gegevens. Toch bestaan er - gezien het transversale karakter van deze studie - aanzienlijke bezwaren tegen gebruik van de gegevens uit dit onderzoek voor het onderhavige doel ${ }^{215}$.

Experimenteel, dubbelblind, gerandomiseerd, gekruist opgezet onderzoek werd door Johnson et al verricht ${ }^{216}$. Zij gaven aan 81 vrouwen met een normalle bloeddruk en 34 vrouwen met een medicamenteus behandelde hypertensie, $1,5 \mathrm{~g}$ calcium per dag. Aan het einde van de studie bleek de calciumsuppletie niet van invloed op de bloeddrukhoogte van de vrouwen met een normale tensie te zijn geweest. Bij de onder behandeling zijnde groep bleek de systolische bloeddruk significant met $13 \mathrm{~mm} \mathrm{Hg}$ afgenomen te zijn onder invloed van calciumtoevoeging. Bij degenen, die geen calciumsuppletie kregen, steeg de systolische bloeddruk met $7 \mathrm{~mm}$ $\mathrm{Hg}$.

Nog minder epidemiologisch onderzoek dan naar de rol van het calcium is naar de etiologische betekenis van magnesium inzake hypertensie verricht ${ }^{124}$. Alleen Kesteloot maakt in een transversale studie melding van een negatieve correlatie tussen de hoogte van het magnesiumgehalte in de 24-uurs urine en de diastolische bloeddruk, zulks na multivariate variantie-analyse ter eliminatie van verstorende variabelen ${ }^{163}$. Deze bevinding is vooral opmerkelijk omdat de opgenomen hoeveelheid magnesium slechts zeer gedeeltelijk via de urine wordt uitgescheiden. Dat geldt overigens eveneens voor calcium (zie paragraaf 2.2.).

2.4. Niveau van de consumptie van keukenzout en daarmee samenhangende mineralen

\subsubsection{Inleiding}

In het voorafgaande is aangetoond dat de voeding in de geïndustrialiseerde samenleving gekenmerkt wordt door een hoog natrium- en een laag kaliumgehalte. In dit opzicht steekt zij ongunstig af bij het voedingspatroon van natuurvolkeren ${ }^{217}$. In het navolgende worden in kort bestek enige gegevens gepresenteerd betreffende de hoogte van het natrium- en 
kaliumgehalte in de voeding van enkele wel en niet geïndustrialiseerde landen. Vervolgens zal nader worden ingegaan op de hoogte van het zoutgebruik in Nederland.

\subsubsection{Buitenlandse gegevens}

Tabel 2 geeft een overzicht van de resultaten van een aantal onderzoekingen op dit terrein. Deze zijn uitgedrukt in mmol natrium en kalium in de 24-uurs urine, hetgeen, zoals in paragraaf 2.2 . is vastgesteld, een goede maat is voor de hoeveelheid die met de voeding wordt opgenomen.

De natriuminneming ligt in een aantal niet-geïndustrialiseerde samenlevingen veel lager dan in de wel geindustrialiseerde landen. Prior vond op de Cook en de Tokelau eilanden waarden variërend van 40 tot 115 mmol per 24 uur ${ }^{180,218}$. Nog veel lagere waarden vond Page op enkele van de Solomons eilanden: 10 tot 30 mmol natrium per 24 uur $^{181}$. Extreem lage waarden vond Oliver bij de Yanomano indianen in Brazilië: 1 à 2 mmol per 24 uur $^{76}$. Oomen vond op Nieuw Guinea ook zulke lage waarden ${ }^{219.220}$.

De uitkomsten die in geïndustrialiseerde landen worden gevonden, vormen hiermee een schril contrast: zij schommelen doorgaans tussen de 100 en $200 \mathrm{mmol}$ natrium per 24 uur $^{221,222,223}$. In Finland liggen de waarden zelfs boven de $200 \mathrm{mmol}$ per 24 uur $^{188}$. Onderzoek uit Japan levert nog hogere waarden op. In bepaalde delen van Japan stijgen deze tot $400 \mathrm{mmol}$ per 24 uur $224: 24$ gram keukenzout ofwel 10 tot 20 maal de fysiologische behoefte 46,48 .

Ook naar de hoogte van het kaliumgebruik is onderzoek verricht. Zoals al eerder werd gemeld, ligt de kaliumexcretie in geindustrialiseerde landen in het algemeen lager dan in niet-geïndustrialiseerde landen. Bij de Yanomano indianen vond Oliver een gemiddelde van $200 \mathrm{mmol} \mathrm{kalium}$ per dag $^{96}$. Prior trof op de Cook- en Tokelau eilanden waarden aan

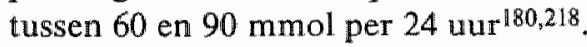

Daarentegen leveren onderzoekingen in de moderne Westerse landen zelden waarden hoger dan 40 tot $70 \mathrm{mmol}$ per 24 uur op. Een uitzondering vormt het Finse onderzoek van Tanskanen, die $82 \mathrm{mmol}$ kalium per dag vond ${ }^{78}$. Deze laatste waarde stemt overigens redelijk overeen met de fysiologische behoefte, die op 50 tot $100 \mathrm{mmol}$ per dag wordt geschat ${ }^{46,48}$.

\subsubsection{Nederlandse gegevens}

Ook in Nederland is, zoals uit tabel 3 blijkt, de laatste jaren onderzoek verricht naar de hoogte van het zoutgebruik. De Voedingsraad unventariseerde recent de resultaten hiervan ${ }^{52}$. Het beeld dat daaruit naar voren komt, wijkt nauwelijks af van dat van andere geïndustrialiseerde landen. 
Niettemin wordt hier wat nader ingegaan op de verschillende studies. Tot de eersten die onderzoek op dit terrein verrichtten, behoorde Ten Bergevan der Schaaf'192. Zij deed in de jaren ' $76-' 78$ onderzoek onder schoolkinderen van 10 tot 13 jaar. Ze bepaalde onder meer de natrium-en de kaliumuitscheiding in de 24-uurs urine. Een soortgelijk onderzoek werd door Hofman et al verricht onder schoolkinderen wan 8 tot 12 jaar. Er werd gezocht naar de relatie tussen de hoogte wan de bloeddruk en het natriumgehalte van het drinkwater ${ }^{225}$. Het natrium in thet drinkwater maakt in het algemeen slechts een klein deel van het totale natrium in de voeding uit. Toch vonden de auteurs verschillen in de 24-uurs uitscheiding van natrium afhankelijk van het gebied waar de kinderen woonden. Het kaliumgehalte in de 24-uurs urine werd eveneens onderzocht.

Een wat oudere leeftijdsgroep werd onderzocht door Breedveld. Hij bepaalde van 34 diëtistes in opleiding ( 20 tot 26 jaar) de gemiddelde natriumuitscheiding. De kaliumexcretie werd niet bepaald ${ }^{226}$. Evenmin deed Kool-Hulshof dat, die in Renkum een aantal jong-volwassen mannen en vrouwen onderzocht. Wat haar onderzoek in dit verband interessant makkt, is dat de auteur niet alleen natrium in de 24-uurs urine bepaalde, maar daarnaast ook trachtte de hoogte van de natriuminneming langs voedingsanamnestische weg vast te stellen ${ }^{227}$. Een van de uitkomsten van haar onderzoek is, dat de waarden die anamnestisch worden verkregen, gemiddeld $25 \%$ lager lagen dan die welke bij de natriumbepaling via de urine gevonden werden.

Egger et al bepaalden drie maal het natriumgehalte in de urine bij 22 mannen, zulks als nulmeting voorafgaande aan een dieet-interventie ${ }^{228}$. De auteurs vonden een inter-individuele variatiecoëfficiënt van $50 \%$. De intra-individuele wariatiecoëfficiënt varieerde van 3 tot $85 \%$.

De hier vermelde onderzoeken betreffen vooral kinderen en jongvolwassenen. De Waard onderzocht in Ede 250 vrouwen van 47 tot 58 jaar in het kader van een longitudinaal onderzoek naar de calciumstofwisseling. Daarbij werd tevens getracht een beeld te krijgen wan de natriuminneming. Het onderzoek leerde dat uit de voedingsanamnese natriumwaarden volgden die gemiddeld $35 \%$ lager waren dan die gemeten in de 24-uurs urine - dus nog weer $10 \%$ meer dan bij het onderzoek van Kool-Hulshof. Kalium werd in dit onderzoek niet bepaald ${ }^{229}$. Naar de natriumexcretie onder bejaarden werd tot op heden, voor zover bekend, slechts éénmaal onderzoek gedaan en dan nog op beperkte schaal. Daenen et al vonden bij negentien mannelijke bejaarden gemiddelde waarden van $137 \mathrm{mmol}$ en bij 14 vrouwelijke bejaarden 117 mmol per 24 uur $^{230}$.

Een bijzondere plaats neemt het onderzoek van Rookus et al in. In het 
kader van onderzoek naar verschillen in prestatievermogen wan lactoovo-vegetariërs en omnivoren werd ook een studie verricht naar het natrium- en kaliumgehalte in de 24-uurs urine. Daarbij bleek dat vegetarische vrouwen minder natrium uitscheidden dan de omnivoren en meer in het algemeen dat er een verschil in natriumuitscheiding tussen beide geslachten bestond ${ }^{231}$.

Volledigheidshalve wordt nog gewezen op een onderzoek van Erwte$\operatorname{man}^{232}$. Deze bepaalde bij 84 patienten, die om "uiteenlopende redenen" een algemeen-interne polikliniek bezochten, het natriumgehalte in de 24uurs urine in het kader van een patient-controle studie. Daarbij vond hij dat personen, die $1000 \mathrm{ml}$ of meer urine per etmaal produceerden, meer natrium ( $156 \mathrm{mmol}$ ) uitscheidden dan personen, die minder dan $1000 \mathrm{ml}$ urine produceerden $(78 \mathrm{mmol})$. Deze gegevens worden overigens niet naar leeftijd en geslacht gepresenteerd.

Recent zijn de resultaten van onderzoek door Vaessen et al gepubliceerd ${ }^{233}$. Op basis van de "dubbele portie" methode (waarop in paragraaf 2.3. is ingegaan) $\mathrm{k}$ wamen de auteurs tot een dagelijkse natriuminneming van gemiddeld $141 \mathrm{mmol}$ en een kaliuminneming van $76 \mathrm{mmol}$. Belangwekkend is de bevinding, dat tussen de zomer- en wintervoeding een verschil in natriumgehalte bestaat. Hetzelfde geldt voor kalium. De door deze auteurs geanalyseerde kaliumwaarden liggen aanzienlijk lager dan de door Kromhout et al berekende waarden ${ }^{206}$. Met behulp van de zogenaamde "dietary history" met kruisvraag-methode, komen zij tot waarden van $102-130 \mathrm{mmol}$ kalium per dag bij mannen van middelbare leeftijd.

Volledigheidshalve volgen tenslotte nog enige opmerkingen over de hoogte van de calcium-en magnesiuminneming door de bevolking. Naar geschat wordt, zouden $20 \mathrm{mmol}$ calcium en 8 tot $17 \mathrm{mmol}$ magnesium per dag toereikend zijn om de verliezen te compenseren. Deze hoeveelheden worden, naar uit de literatuur blijkt, over het algemeen ruimschoots gehaald $2,47,62,76,90,92,93,206$.

De hierboven gemelde onderzoekingen geven ook tezamen geen volledig beeld over het natrium- en kaliumgebruik in Nederland. Allereerst blijkt, dat sommige onderzoekers slechts een klein aantal personen onderzochten en dat de leeftijdscategorieèn nogal beperkt waren. Anderen makkten geen uitsplitsing naar leeftijd en geslacht. Voorts moet men zich realiseren dat kalium slechts in enkele gevallen en de molaire natrium/kalium ratio slechts in éen geval werd berekend. Als een tekortkoming kan vervolgens het feit worden beschouwd dat noch de natrium- noch de kaliumexcretie in relatie tot anthropometrische gegevens - lichaamslengte en -gewicht of de daaruit te berekenen 
Quetelet-index - werden onderzocht. Ook aan de binnenpersoonsvariatie werd door de onderzoekers onvoldoende aandacht geschonken.

De kennis over het gebruik van natrium en kalium door de bevolking vertoont bijgevolg nog duidelijke hiaten. 


\section{PROBLEEMSTELLING}

\subsection{Inleiding}

Op grond van het voorafgaande moge duidelijk zijn geworden dat er aanwijzingen zijn dat er een relatie bestaat tussen de hoogte van het zoutgebruik en het vóórkomen van hypertensie. Volledig duidelijk is dit verband echter niet. Epidemiologische studies laten zien, dat genoemde samenhang op populatieniveau wel, doch op individueel niveau niet overtuigend kan worden aangetoond. Kennis opgedaan in experimenteel (interventie) onderzoek verschaft ook geen volledige duidelijkheid in dezen.

De (patho)fysiologie levert evenwel sterke aanwijzingen als steun voor de zoutbloeddrukhypothese. Zo is aangetoond dat natrium en kalium en met name de molaire natrium/kalium ratio - van groot belang zijn bij de bloeddrukregulatie. Tevens blijkt steeds vaker dat ook andere ionen zoals calcium en magnesium van betekenis zijn. Het is duidelijk, dat epidemiologische en fysiologische gegevens ieder hun eigen bijdrage leveren aan de hypothesevorming inzake mineralen en bloeddrukregulatie. In de etiologische bewijsvoering zullen zij elkaar kunnen aanvullen doch nimmer vervangen. Uit het voorafgaande is gebleken dat de mogelijkheden om langs epidemiologisch, observationeel onderzoek aan een sluitende theorie voor bedoelde problematiek bij te dragen, echter beperkt $z i j n^{215}$. Het aantal (verstorende) variabelen in deze materie is niet alleen zeer groot, deze variabelen zijn veelal bovendien afhankelijk van elkaar. Dit brengt niet te onderschatten methodologische problemen met zich mee; met name omdat de etiologische bewijskracht uit lang lopend, longitudinaal onderzoek moet komen. Lang lopend interventieonderzoek is om dezelfde redenen niet goed haalbaar.

De sterke intra-individuele variatic in het consumptiepatroon van personen levend in de geïndustrialiseerde wereld bemoeilijkt voorts het vaststellen van de individuele hoogte van het natrium-en kaliumgebruik via de 24-uurs urine. De epidemiologische gegevens overziend, concluderen Elliot et al dan ook dat: "Many of the reports in the literature can be criticised on methodological grounds"154. Kesteloot gaat zelfs nog verder en stelt: "Epidemiologisch onderzoek is belangrijker om in bevolkingen de bloeddruk en de inname van natrium, kalium, calcium en magnesium te bepalen dan om eventuele causale verbanden tussen 
kationen en bloeddruk aan te tonen"155,163. Onze conclusie zou eerder zijn dat alleen epidemiologisch onderzoek in combinatie met interventieen fysiologisch onderzoek antwoord zal geven op de vraag naar causaliteit en mechanismen.

\subsection{Afbakening van de probleemstelling}

Los van de onduidelijkheid omtrent de complexe relaties tussen het zout - of liever de mineralen natrium, kalium, calcium en magnesium in de voeding en het ontstaan van hypertensie staat, dat omtrent de hoogte van de inneming van genoemde mineralen door de bevolking onvoldoende bekend is ${ }^{2,8,51}$. Deze gegevens zijn, zoals in hoofdstuk 1 is gesteld, niet alleen uitermate relevant in het kader van de discussie over primaire preventie van hypertensie als volksgezondheidsvraagstuk maar ook in het licht van de secundaire preventie.

Preventie, vroege opsporing en behandeling van hypertensie heeft immers hoge prioriteit in de gezondheidszorg $234,235,236$. In kwantitatief opzicht gaat het met name om personen met een lichte hypertensie. De behandeling bestaat dan allereerst uit een niet-farmacologische benaderingswijze. Hierbij zijn beperking van het lichaamsgewicht en reductie van het gebruik van keukenzout de belangrijkste vormen. Wil de huisarts zijn werk naar behoren vervullen, dan dient er ook in dit verband duidelijkheid te bestaan over de hoogte van het zoutgebruik door de populatie in kwestie alsmede over de mogelijkheden dit te beperken.

Met deze doelstelling voor ogen is in de stad Brielle een beschrijvend, explorerend onderzoek gedaan naar de hoogte van het gebruik van genoemde nutriënten en de voedingsmiddelen waarin zij vóórkomen. Op grond van de in het literatuuronderzoek aangegeven bezwaren is afgezien van het zoeken naar een verband tussen de mineraleninneming en de bloeddruk.

De vraagstellingen welke zijn onderzocht zijn in het navolgende meer in detail weergegeven.

\subsection{Specifieke onderzoeksvraagstellingen}

De volgende vraagstellingen zijn geformuleerd:

I. Hoe hoog is de uitscheiding van natrium, kalium, calculum en magnesium in de 24-uurs urine van de volwassen bevolking van Brielle?

II. Hoe hoog is de bloeddruk en de Quetelet-index van de onderzoekspopulatie?

III. Hoe groot is de intra-individuele ("van-dag-tot-dag") variatie van de excretie van genoemde mineralen in de urine?

IV. In hoeverre is de uitscheiding van natrium, kalium, calcium en 
magnesium afhankelijk van factoren als geslacht, leeftijd, urineverzameldag, welstandsklasse, burgerlijke staat, ziektegeschiedenis voor hart-en vaatziekten en hypertensie, bloeddrukverlagende medicatie, het gebruik van een natriumbeperkt dieet en de hoogte van de Quetelet-index?

V. Hoe hoog is in de onderzoekspopulatie de opname van natrium, kalium, calcium en magnesium via voedingsmiddelen waarvan bekend is dat zij een hoog gehalte aan de desbetreffende mineralen bevatten? In welke mate correspondeert deze berekende mineraalinneming met de uitscheiding ervan in de urine? 


\section{ONDERZOEKSMETHODE}

\subsection{Selectie van de onderzoekspopulatie}

\subsubsection{Het steekproefkader}

De basispopulatie voor het onderzoek bestond uit de volwassen bevolking van de Zuidhollandse stad Brielle. Het bevolkingsregister van de stad is niet geautomatiseerd. Het is derhalve niet mogelijk om op ieder willekeurig tijdstip over de actuele demografische gegevens te beschikken. De totaaltellingen geschieden eens per jaar, rond de eerste januari.

Op 19 december 1980 telde Brielle 11.355 inwoners. Van deze personen hadden 5410 het mannelijke en 5514 het vrouwelijke geslacht. Van 431 burgers was wel de leeftijd maar niet het geslacht en/of de huwelijkse staat bekend ("apart vermelden"). Tot deze groep behoorden de mensen die een vreemde of dubbele nationaliteit bezaten dan wel uitgesloten waren van kiesrecht. In totaal waren 8293 personen 18 jaar of ouder $(73 \%)$. Het aantal mannen van wie alle gegevens bekend waren, bedroeg 3942 , het aantal vrouwen 4044 .

Tabel 4 geeft een overzicht van de opbouw van de Brielse bevolking van 18 jaar en ouder naar onderscheiden leeftijdscategorieën, geslacht en huwelijkse staat. Volgens gegevens van het Centraal Bureau voor de Statistiek (CBS), is de bevolkingsopbouw van de gemeente Brielle naar leeftijd, geslacht en burgerlijke staat goed vergelijkbaar met de totale Nederlandse bevolking 237 .

\subsubsection{Het trekken van de steekproef}

Gekozen is voor een naar geslacht gestratificeerde steekproef. Om voldoende deelnemers per leeftijdscategorie te krijgen, is de totale grootte van de steekproef op 1500 personen gesteld, 750 mannen en 750 vrouwen. Voor een populatiestudie als de onderhavige wordt een aantal van ongeveer 500 deelnemers genoemd ${ }^{78}$. De benodigde steekproefomvang hangt onder andere af van de mate van variatie in de te meten kenmerken en van het aantal en de omvang van de strata warin men de totale populatie ten behoeve van subanalyses wil opsplitsen. Bij het bepalen van de grootte van de steekproef is tevens rekening gehouden met een nonrespons van $50 \%{ }^{78}$.

Op 18 juni 1981 is uit 3965 mannen en 4063 vrouwen een aselecte steekproef van 750 mannen en 750 vrouwen getrokken. Uit de op 
kiesdistrict en straatnaam gerangschikte persoonsgegevens in het bevolkingsregister, is steeds het wijfde ponsplaatje getrokken (firma Vermande). Vervolgens zijn uit de aldus verkregen steekproef 43 mannen en 63 vrouwen aselect verwijderd door bij de mannen afwisselend het $17^{\circ}$ en het $18^{\mathrm{e}}$ en bij de vrouwen het $12^{\mathrm{E}}$ ponsplaatje te trekken. De resterende aantallen zijn "blind" gelicht. De samenstelling van de bevolking was op 18 juni iets gewijzigd ten opzichte van de laatste totaaltelling.

Ter bepaling van de intra-individuele variabiliteit in ionenuitscheiding in de urine is aan een aantal personen gevraagd, om voor een tweede maal de 24-uurs urine te verzamelen. Uit de lijst van deelnemers zijn aan het einde van de onderzoeksperiode, aselect 140 personen (16\%) getrokken en telefonisch benaderd. Het betrof 70 mannen en 70 vrouwen.

\subsubsection{Vitsluitingscriteria}

Van deelneming aan het onderzoek zijn degenen die onvolledige gegevens leverden, uitgesloten. Hiertoe behoorden met name personen met foutief of slechts gedeeltelijk ingevulde onderzoeksformulieren. Vanzelfsprekend vielen de deelnemers, die de 24-uurs urine niet inleverden, ook af. Degenen die de urine onvolledig verzamelden, zijn eveneens uitgesloten. Ter controle hierop is allereerst aan de deelnemers gevraagd te melden of zij in de gelegenheid waren geweest de 24-uurs urineverzameling compleet uit te voeren. In dat geval kregen zij een nieuwe verzamelfles uitgereikt. Bij inlevering is navraag naar eventuele problemen gedaan. Tevens is aan de hand van de genoteerde verzameltijden nagegaan of de verzameling de gehele 24 uur bestreek. Zo niet, dan werd contact opgenomen met de betrokkene; lukte dit niet, dan werden de betreffende personen van verdere verwerking uitgesloten.

\subsection{De gegevenswerzameling}

\subsubsection{Anamnestische gegevens}

De anamnestische gegevens zijn op drie formulieren vastgelegd. Een formulier diende voor het vastleggen van gegevens over medicijn- en dieetgebruik en anamnestische gegevens betreffende hart- en vaatziekten en hypertensie. Het tweede formulier bevatte ragen over de opleiding en het beroep van de deelnemer en van de eventuele partner.

Het derde formulier was bedoeld gegevens vast te leggen over de hoogte van de consumptie van een aantal voedingsmiddelen: brood, kaas, vleeswaren, gevogelte, vis, vlees, melk en melkprodukten, ei, groente, fruit en aardappelen. De gebruikelijke consumptie van deze voedingsmiddelen is nagegaan door middel van een gestructureerde vragenlijst. 
Schriftelijk is gevraagd naar de frequentie van het gebruik en naar de gebruikte hoeveelheid (in huishoudelijke maten) per gebruiksdag ${ }^{74}$. De verkregen gegevens zijn omgerekend naar grammen dan wel milliliters geconsumeerde voeding per dag. Daarna is het gehalte aan natrium, kalium, calcium en magnesium in deze dagporties berekend. Een onderzoeksassistente nam alle formulieren met de deelnemers door op onduidelijkheden en volledigheid (zie bijlagen).

Uit de literaturur is bekend, dat de hoogte van het gebruik van de onderzochte ionen met tal van factoren samenhangt. In de anamnese is daarom aan deze factoren alsook aan een aantal verstorende variabelen aandacht besteed.

$==$ Leeftijd en geslacht.

In het algemeen blijkt het voedingspatroon niet alleen rechtstreeks afhankelijk van de leeftijd en het ges\acht te zijn, maar ook indirect via bijvoorbeeld leef- en werkomstandigheden alsook de economische situatie $^{62}$. Door de Nederlandse Voedingsraad worden aambevelingen voor een verantwoord voedungspatroon dan ook naar leeftijd en geslacht gege$v^{2}{ }^{76}$. Meer in het bijzonder blijkt uit literatuuronderzoek, dat de hoogte van de natrium-, kalium-, calcium-en magnesiumuitscheiding samen lijkt te hangen met de leeftijd en het geslacht ${ }^{78,81,186,205}$.

In het onderhavige geval is de onderzoekspopulatie in zeven leeftijdscategoriẻn ingedeeld:

$18 \%$ m 24 jaar

$25 \%$ m 34 jaar

$35 \mathrm{t} / \mathrm{m} 54$ jaar

$55 \mathrm{t} / \mathrm{m} 59$ jaar

$60 \%$ jaar

$65 \%$ maar

70 jaar en ouder

Deze indeling is verder gedifferentieerd dan die in de Nederlandse Voedingsmiddelentabel ${ }^{76}$.

$==$ Welstandsklasse.

Volgens sommige auteurs zouden de leden van de lagere sociaal-economische klassen een hogere natriumuitscheiding in de 24-uurs urine vertonen dan personen uit de hogere klassen ${ }^{81}$. Tevens werd gevonden, dat vrouwen uit de hogere wellstandsklassen een hogere kaliumuitscheiding in de 24-uurs urine laten zien in vergelijking met de laagste klassen ${ }^{81}$.

De sociaal-economische achtergrond van de deelnemers aan het hier beschreven onderzoek, is bepaald aan de hand van een combinatie van gegevens betreffende opleiding en functie, eventueel van beide partners. 
Kiesdistrict en straatnaam gerangschikte persoonsgegevens in het bevolkingsregister, is steeds het vijfde ponsplaatje getrokken (firma Vermande). Vervolgens zijo uit de aldus verkregen steekproef 43 mannen en 63 vrouwen aselect verwijderd door bij de mannen afwisselend het $17^{\mathrm{e}}$ en het $18^{\mathrm{c}}$ en bij de vrouwen het $12^{\circ}$ ponsplaatje te trekken. De resterende aantallen zijn "blind" gelicht. De samenstelling van de bevolking was op 18 juni iets gewijzigd ten opzichte van de laatste totaaltelling.

Ter bepaling van de intra-individuele variabiliteit in ionenuitscheiding in de urine is aan een aantal personen gevraagd, om voor een tweede maal de 24-uurs urine te verzamelen. Uit de lijst van deelnemers zijn aan het einde van de onderzoeksperiode, aselect 140 personen (16\%) getrokken en telefonisch benaderd. Het betrof 70 mannen en 70 vrouwen.

\section{1.3. Uits/uitingscriteria}

Van deelneming aan het onderzoek zijn degenen die onvolledige gegevens leverden, uitgesloten. Hiertoe behoorden met name personen met foutief of slechts gedeeltelijk ingevulde onderzoeksformulieren. Vanzelfsprekend vielen de deelnemers, die de 24-uurs urine niet inleverden, ook af. Degenen die de urine onvolledig verzamelden, zijn eveneens uitgesloten. Ter controle hierop is allereerst aan de deelnemers gevraagd te melden of zij in de gelegenheid waren geweest de 24-uurs urineverzameling compleet uit te voeren. In dat geval kregen zij een nieuwe verzamelfles uitgereikt. Bij inlevering is navraag naar eventuele problemen gedaan. Tevens is aan de hand van de genoteerde verzameltijden nagegaan of de verzameling de gehele 24 uur bestreek. Zo niet, dan werd contact opgenomen met de betrokkene; lukte dit niet, dan werden de betreffende personen van verdere verwerking uitgesloten.

\subsection{De gegevensverzameling}

\subsubsection{Anamnestische gegevens}

De anamnestische gegevens zijn op drie formulieren wastgelegd. Een formulier diende voor het vastleggen van gegevens over medicijn- en dieetgebruik en anamnestische gegevens betreffende hart- en vaatziekten en hypertensie. Het tweede formulier bevatte vragen over de opleiding en het beroep van de deelnemer en van de eventuele partner.

Het derde formulier was bedoeld gegevens vast te leggen over de hoogte van de consumptie van een aantal voedingsmiddelen: brood, kaas, vleeswaren, gevogelte, vis, vlees, melk en melkprodukten, ei, groente, fruit en aardappelen. De gebruikelijke consumptie van deze voedingsmiddelen is nagegaan door middel van een gestructureerde vragenlijst. 
Schriftelijk is gevraagd naar de frequentie van het gebruik en naar de gebruikte hoeveelheid (in huishoudelijke maten) per gebruiksdag ${ }^{74}$. De verkregen gegevens zijn omgerekend naar grammen dan wel milliliters geconsumeerde woeding per dag. Daarna is het gehalte aan natrium, kalium, calcium en magnesium in deze dagporties berekend. Een onderzoeksassistente nam alle formulieren met de deelnemers door op onduidelijkheden en volledigheid (zie bijlagen).

Uit de literatuur is bekend, dat de hoogte van het gebruik van de onderzochte ionen met tal van factoren samenhangt. In de anamnese is daarom aan deze factoren alsook aan een aantal verstorende variabelen aandacht besteed.

\section{$==$ Leeftijd en geslacht.}

In het algemeen blijkt het voedingspatroon niet alleen rechtstreeks afhankelijk van de leeftijd en het geslacht te zijn, maar ook indirect via bijwoorbeeld leef-en werkomstandigheden alsook de economische situa$4 e^{62}$. Door de Nederlandse Voedingsraad worden aanbevelingen voor een verantwoord voedingspatroon dan ook naar leeftijd en geslacht gegeven ${ }^{76}$. Meer in het bijzonder blijkt uit literatuuronderzoek, dat de hoogte van de natrium-, kalium-, calcium- en magnesiumuitscheiding samen lijkt te hangen met de leeftijd en het geslacht $78,81,186,205$.

In het onderhavige geval is de onderzoekspopulatie in zeven leeftijdscategoriën ingedeeld:

$18 \% / \mathrm{m} 24$ jaar

$25 \% / \mathrm{m} 34$ jaar

$35 \%$ m 54 jaar

$55 \%$ m 59 jaar

$60 \%$ m 64 jaar

$65 \%$

70 jaar en ouder

Deze indeling is verder gedifferentieerd dan die in de Nederlandse Voedingsmiddelentabel ${ }^{76}$.

\section{$==$ Welstandsklasse.}

Volgens sommige auteurs zouden de leden van de lagere sociaal-economische klassen een hogere natriumuitscheiding in de 24-uurs urine vertonen dan personen uit de hogere klassen ${ }^{81}$. Tevens werd gevonden, dat vrouwen uit de hogere welstandsklassen een hogere kaliumuitscheiding in de 24-uurs wrine laten zien in vergelijking met de laagste klassen ${ }^{81}$.

De sociaal-economische achtergrond van de deelnemers aan het hier beschreven onderzoek, is bepaald aan de hand van een combinatie van gegevens betreffende opleiding en functie ${ }_{*}$ eventueel van beide partners. 
In deze Attwood-schaal onderscheidt men vijf categorieèn: $A B$ als hoogste, $\mathrm{C} 1$ en $\mathrm{C} 2$ als gedifferentieerde middengroep en $\mathrm{D} 1$ en $\mathrm{D} 2$ als laagste categorien. De groep 0 is bestemd voor de categorie "onbekend"238. Gekozen is voor een reductie van het aantal klassen tot vier: $A B, C$ (was C1 en C2) D (was D1 en D2) en 0 .

$=$ Burgerlijke staat.

Uit Fins onderzoek van Tanskanen is naar voren gekomen, dat getrouwde wrouwen een hogere natrium- en kaliumexcretie in de 24-uurs urine hebben dan ongetrouwde deelneemsters ${ }^{78}$. Daarom zijn twee klassen onderscheiden: 1) alleenstaanden (ongehuwden, weduwen of weduwnaren) en 2) samenwonenden (gehuwden en ongehuwden).

De verschillende te onderzoeken factoren worden in tabel 5 gepresenteerd. Tevens zijn hier enige onafhankelijke variabelen in opgenomen, die een verstorende werking op de uitkomsten kunnen hebben. Door sommige auteurs wordt de mogelijkheid geopperd, dat personen met een belaste anamnese voor hart- en vaatziekten en hypertensie een ander voedingspatroon zouden hebben dan personen met een blanco anamnese ${ }^{78,157,205}$. Ook bij het gebruik van diuretica of andere bloeddrukverlagende middelen is beschreven, dat deze leiden tot een afwijkende natrium- en kaliumuitscheiding ${ }^{78}$. Dat tenslotte de factor "gebruik van een natriumbeperkt dieet" is ingevoerd, behoeft geen nadere motivering 230 .

\subsubsection{Anthropometrische gegevens, bloeddruk en polsfrequentie}

$==$ Lichaamsbouw.

Een aparte plaats verdient de relatie tussen lichaamsbouw en voedselconsumptie. De mening, dat obesen een grotere voedselconsumptie hebben dan personen met een lager lichaamsgewicht wint, ondanks vele tegenstrijdige gegevens, terrein ${ }^{169}$. Verschillende auteurs vonden een positieve relatie tussen de hoogte van de Quetelet-index en de hoogte van de natrium- en kaliumexcretie in de 24-uurs urine ${ }^{78,81,87,160,192}$. Daarom is in het hier beschreven onderzoek een onderscheid gemaakt tussen personen met een Quetelet-index $(\mathrm{QI}) \leqslant 22,22<\mathrm{QI}<28, \mathrm{QI} \geqslant 28$ alsmede hiervan de personen met een $\mathrm{QI} \geqslant 30$.

Het lichaamsgewicht is bepaald met behulp van een opstapweegschaal (SECA), veermodel. De personen thadden geen schoenen of dikke kleding aan. De aflezing geschiedde tot $0,1 \mathrm{~kg}$ nauwkeurig.

De lichaamslengte is bepaald terwijl de personen zonder schoenen, rechtop tegen een houten paneel stonden. Met behulp van een schuifmeetlat (Microtoise) is de lengte tot op $0,1 \mathrm{~cm}$ nauwkeurig bepaald. Uit 
de verkregen gegevens is de Quetelet-index berekend. Deze Queteletindex is het quotiënt van het lichaamsgewicht $(\mathrm{kg})$ en de lichaamslengte $(m)$ in het kwadraat $\left(G / L^{2}\right)$.

De kniebreedtemeting is verricht aan de linker en rechter knie, ter hoogte van de beide condylen. De meting geschiedde in zittende houding met de knie gebogen in een hoek van $90^{\circ}$. De met behulp van een breedbladige schuifpasser (CIVO-TNO) bepaalde waarden werden gesommeerd gemoteerd en bij de latere bewerking gemiddeld. De afleesnauwkeurigheid bedroeg $0,1 \mathrm{~cm}$.

De bloeddrukmeting geschiedde met behulp van een $\mathrm{kwik}$-manometer (S\&K). De afmeting van de luchtkamer van de bloeddrukkleefmanchet bedroeg $15 \times 42 \mathrm{~cm}$. Er zijn twee metingen verricht na een rustperiode (ca. $10 \mathrm{~min}$.), in zittende houding. De hoogte van de bloeddruk is bepaald in hele $\mathrm{mm} \mathrm{Hg}$. Tussen de beide metingen zat een tijdswerschil van minimaal twee minuten. Indien het verschil tussen de systolische waarden van de eerste en de tweede meting minder dan $10 \mathrm{~mm} \mathrm{Hg}$ bedroeg, zijn de resultaten van die beide metingen gemiddeld. Bedroeg het verschil $10 \mathrm{~mm}$ $\mathrm{Hg}$ of meer, dan werden opnieuw twee metingen verricht. De laatst gemeten systolische bloeddrukwaarden zijn gemiddeld en aangehouden, ook indien het verschil wederom 10 of meer $\mathrm{mm} \mathrm{Hg}$ bedroeg.

Als diastolische bloeddrukwaarde is fase $\mathrm{V}$, het moment waarop de Korotkofftonen geheel verdwijnen, aangehouden ${ }^{8}$. Wanneer het verschil tussen de diastolische waarden van de eerste en de tweede meting minder dan $8 \mathrm{~mm} \mathrm{Hg}$, bedroeg, zijn de resultaten van beide metingen gemiddeld. Bedroeg het verschil 8 of meer $\mathrm{mm} \mathrm{Hg}$, dan werden opnieuw twee metingen verricht. De laatst gemeten diastolische bloeddrukwaarden zijn gemiddeld en aangehouden, ook indien het verschil wederom 8 of meer $\mathrm{mm} \mathrm{Hg}$ bedroeg.

De Korotkofftonen zijn beluisterd met een stethoscoop (AKA) met korte slang.

De polsfrequentie is tenslotte gedurende éen hele minut geteld. Dit geschiedde met behulp van een stopwatch (Elka Watch $\mathrm{Cy}$ ).

Al deze handelingen zijn uitgevoerd door één ervaren doktersassistente na uitvoerige instructie ( ${ }^{239}$, Ravin-geluidsband).

\subsubsection{De urineverzameling}

\section{$=$ Urineverzameldag.}

De literatuur bevestigt dat het woedingspatroon van dag tot dag varieert ${ }^{240,241}$. Liu et al vonden bijwoorbeeld een 5-10\% lagere natriumuitscheiding in de 24 -uurs urine, wellke in het weekend was verzameld ${ }^{85}$. Anderen bevestigen dit overigens niet ${ }^{81}$. De zeven urineverzameldagen 
van de week zijn in het Brielse onderzoek aanvankelijk onderscheiden.

De urineverzamelflessen, trechters en deksels zijn vóór gebruik met gedemineraliseerd water gereinigd. Om bacteriegroei in de verzamelde urine tegen te gaan, is vervolgens aan iedere fles $5 \mathrm{cc}$ van een Thymoll/Isopropanol $10 \%$ oplossing toegevoegd ${ }^{81}$.

De deelnemers kregen een drie-literfles mee naar huis om de 24-uurs urine in te verzamelen. De vrouwelijke deelnemers kregen tevens een trechter mee. De flessen werden gecodeerd, op het etiket werden persoonsgegevens en verzameltijden genoteerd. De keuze van de verzameldag was vrij. Het verzoek was de gevulde fles op de dag na de verzameling te retourneren. Bij verzameling op vrijdag of zaterdag werd verzocht de fles op een koele plaats te bewaren alvorens deze maandagochtend in te leveren.

De teruggebrachte flessen zijn op een getarreerde balans gewogen (Sauter). Aldus is het volume van de verzamelde urine berekend. Met behulp van een Finn-pipet zijn vervolgens na homogeniseren van de urine vijf monsters van $5 \mathrm{cc}$ en één monster van $10 \mathrm{cc}$ genomen en overgebracht in monsterbuisjes. Deze werden gecodeerd en in rekjes bij $-22^{\circ} \mathrm{C}$ bewaard.

De pracedure rond de tweede urineverzameling was dezelfde als die tijdens de eerste.

Al deze handelingen werden door één ervaren medisch analiste uitgevoerd.

In het laboratorium van de vakgroep Humane Voeding van de Landbouwhogeschool te Wageningen (Prof. Dr. J.G.A.J. Hautvast, Prof. Dr. M.B. Katan) is van alle urinemonsters het gehalte aan natrium en kalium bepaald met behulp van een vlamfotometrische methode. Het laboratorium van het St. Rafaël ziekenhuis te Leuven (Prof. Dr. J.V. Joossens) bepaalde van alle urinemonsters de gehalten aan calcium, magnesium en creatinine met behulp van respectievelijk een EDTAtitratie methode, atomaire absorptie spectrofotometrie en een Technicon Autoanalyser ${ }^{81}$. De urinemonsters zijn in diepgevroren toestand naar de genoemde laboratoria gebracht. Alle onderzoeksresultaten van de urinemonsters zijn, evenals de onderzoeksformulieren, bij het Instituut CIVO Toxicologie en Voeding TNO te Zeist verzameld (Prof. Dr. Ir. R.J.J. Hermus). De statistische verwerking van alle onderzoeksresultaten vond hier plaats (Drs. R.J. Egger, Drs. M. Wedel, K. Hulshof).

\subsection{De gegevensverwerking}

Het gaat in dit onderzoek om een aantal onafhankelijke en afhankelijke variabelen. Derhalve zijn in eerste instantie - geclassificeerd door combinaties van onafhankelijke variabelen - kruistabellen met de 
diverse afhankelijke variabelen gemaakt. Tabellen zijn gevormd op grond van de volgende vijf combinaties:

leeftijd, geslacht, urineverzameldag

leeftijd, geslacht, welstandsklasse.

geslacht, burgerlijke staat.

geslacht, anamnese hart- en vaatziekten.

geslacht, medicijngebruik, gebruik natriumbeperkt dieet, anamnese hypertensie.

Per afhankelijke variabele (anthropometrische gegevens, polsfrequentie en bloeddrukwaarden alsmede de bepalingen in de 24-uurs urine) zijn zo steeds vijf tabellen gevormd. Het aantal waarnemingen per cel, het gemiddelde, de standaarddeviatie en de standaardafwijking van het gemiddelde zijn opgenomen. Deze frequentie tabellen zijn bedoeld als beschrijving van de waarden van de gemeten variabelen. Hieruit kunnen nog geen conclusies worden getrokken over de effecten van de onafhankelijke variabelen op de getabelleerde variabelen. De mogelijkheid bestaat immers dat zich verstrengeling met andere onafhankelijke variabelen voordoet, die eveneens een effect op de gemeten afhankelijke variabele hebben. Met andere woorden: de ingevoerde onafhankelijke variabelen zijn onderling niet onafhankelijk. De gegevens (nominale meetniveaus) werden daarom met behulp van een inorthogonale variantie-analyse met een additief model verder geanalyseerd. Daarbij wordt het effect van iedere factor gecorrigeerd voor de hoofdeffecten van de andere factoren $242,243,244$. Met de uit inorthogonale variantie-analyse gevonden $F$-waarde (variance ratio) is berekend of het betreffende effect van de factor (onafhankelijk variabele) op de afhankelijke variabele, statistisch significant is. Vervolgens is iedere variabele getabelleerd op grond van de factoren, die volgens de analyse een significant effect bleken te hebben $(P<0,05)$. Met behulp van deze tabellen kunnen wel verschillen tussen alle combinaties van factorniveaus worden nagegaan. Uit deze tabellen kunnen verschillen tussen celgemiddelden worden getoetst met behulp van een $\mathrm{t}$-toets. De t-waarden worden getoetst bij de gewenste overschrijdingskans met het aantal vrijheidsgraden van het residu in de anallyse 245 .

Gezien de aanwezigheid van significante effecten, mogen eigenlijk geen marginale gemiddelden over deze tabellen worden berekend. Slechts over gewogen gemiddelden van niet significant verschillende klassen binnen afhankelijke variabelen, kunnen binnen de betreffende tabel uitspraken worden gedaan. Uiteindelijk worden tabellen naar leeftijd en geslacht opgenomen. Het lage percentage verklaarde variantie rechtvaardigt dit. 
Per afhankelijke variabele is ook berekend welk percentage wan de totale variantie door elk van de factoren, onafhankelijk van de overige factoren, wordt verklaard. In paragraaf 5.4. wordt hierop, aan de hand van de gevonden resultaten, nader in gegaan.

Tenslotte is de gezamenlijke invloed van alle factoren op ieder van de afhankelijke variabelen nagegaan. Deze is weergegeven als percentage totaal verklaarde variantie van de afhankelijke variabele door de combinatie van deze factoren. Aangezien de factoren onderling niet onafhankelijk zijn, is de som van de door deze factoren afzonderlijk verklaarde percentages variantie, niet noodzakelijkerwijs gelijk aan de totaal verklaarde variantie.

De mogelijke samenhang tussen de hoogte van de Quetelet-index en de natrium-en kaliumuitscheiding in de 24-uurs urine alsmede de systolische en diastolische bloeddruk is apart bestudeerd. Gezien de aard van het meetniveau is gebruik gemaakt van stapgewijze regressie-analyse. Ook hier is multivariate variantie-analyse vereist. Een rang-correlatie of product-moment correlatie toets zou immers een gestrengelde invloed van een of meer onafhankelijke variabelen op de afhankelijke variabele niet meer kunnen onderscheiden ${ }^{242}$.

Voor het bepalen van de intra-individuele variabiliteit van de afhankelijke variabelen uit de 24-uurs urine is gebruik gemaakt van een tweede urineverzameling door een aantal, aselect getrokken deelnemers.

De eerste en de tweede bepaling zijn steeds per persoon met elkaar vergeleken. Deze uitkomsten zijn getoetst met een t-toets van Student voor het verschil tussen gepaarde waarnemingen ${ }^{246}$. Tevens is Pearson's correlatiecoëfficiënt, ( $r$ ) van de eerste en tweede uitscheidingswaarde berekend. De mate van significantie van de correlatiecoëfficiënt is bepaald ${ }^{246}$.

Op grond van de twee aan één individu verrichte urinemetingen, is tevens de gepoolde binnenpersoonsvariantie berekend. De totale variantie is opgesplitst in een variantie tussen en binnen personen ${ }^{245}$. De variatiecoëfficiènt is bepaald als het quotiënt van de standaarddeviatie binnen personen en de gemiddelde waarde van de betreffende parameter. Deze variatiecoefficient is berekend voor alle personen, ongeacht leeftijd en geslacht.

Berekend kan nu ook worden hoe groot het aantal waarnemingen aan één individu zou moeten zijn om de standaardafwijking van het gemiddelde binnen nawwe grenzen - 10\% - van dat gemiddelde te houden. Deze standaardafwijking van het gemiddelde neemt immers af met het toenemen van het aantal waarnemingen. De betrouwbaarheid van de uitspraak dat het gevonden gemiddelde, de werkelijke - individuele waarde is, neemt bij een groter aantal metingen toe. 


\section{RESULTATEN}

\subsection{Kenmerken van de onderzoekspopulatie}

\subsubsection{De steekproef}

De 1500 mannen en vrouwen uit de steekproef zijn na selectie in zeven leeftijdscategorieën ingedeeld. Tabel 6 geeft een overzicht van de totale steekproef naar leeftijd en geslacht. In de bijlage is tabel a opgenomen, die tevens de verdeling naar burgelijke staat laat zien.

Van de 309 personen die in het bevolkingsregister onder "apart vermelden" stonden, zijn er 54 in de steekproef terecht gekomen. Het betreft steeds personen met een vreemde of dubbele nationaliteit. Deze groep bestaat uit mensen, die hier enige jaren veelal met hun gezinnen verblijven. Aangezien de persoonsgegevens nu wel bekend zijn, is deze groep bij de anderen onder gebracht.

Het aantal personen in de onderzoekspopulatie is, zoals te verwachten valt bij een niet voor leeftijd gestratificeerde steekproef, ongelijk over de verschillende leeftijdscategorieën verdeeld. De leeftijdsverdeling van de onderzoekspopulatie komt redelijk overeen met die van de totale populatie. De grootste groep wordt gevormd door personen uit de leeftijdscategorie 35-54 jaar: 38\%. De 60-64 jarigen zijn met 4\% het minst in getal.

De procentuele verdeling van de steekproef naar burgelijke staat komt eveneens goed overeen met die van de totale Brielse bevolking.

\subsubsection{De opkomst, deelnemers en niet-deelnemers}

In de eerste 3 weken na het bezorgen van de uitnodigingsbrief op 17 augustus 1981 , maakten circa 600 personen een afspraak. Daarna nam het aantal aanmeldingen af.

Half september werd een advertentie in de locale weekbladen geplaatst (bijlage). Begin oktober hadden zo'n 450 mensen de 24-uurs urine verzameld en ingeleverd. Ongeveer 250 personen hadden een afspraak gemaakt of waren met de urineverzameling bezig. Slechts 28 personen lieten weten niet mee te zullen doen. Aan $395(53 \%)$ mannen en aan $321(43 \%)$ vrouwen werd een herhalingsoproep gestuurd (bijlage). Hierop steeg het aantal reacties snel. Ruim 200 mensen reageerden positief, 112 gaven te kennen van deelname af te zien.

Van de 1500 aangeschreven personen (750 mannen en 750 vrouwen) 
liet $72,3 \%$ iets van zich horen ( 505 mannen en 579 vrouwen). $59,2 \%$ leverde verwerkbare urines in (411 mannen en 477 vrouwen).

Van $3,7 \%$ waren de gegevens niet bruikbaar ( 23 mannen en 32 vrouwen) terwij1 $9,4 \%$ liet weten niet mee te zullen doen ( 71 mannen en 70 vrouwen). Deze laatste twee groepen vormen samen met de $27,7 \%$ nonresponders ( 245 mannen en 171 wrouwen) de groep van $40,8 \%$ "nietdeelnemers" (339 mannen en 273 wrouwen). Samenvattend is de groep van 1500 aangeschreven personen te verdelen in $888(59,2 \%)$ deelnemers en $612(40,8 \%)$ niet-deelnemers. Schema 3, tabel 7 en tabel 8 geven een overzicht.

In de bijlage is tabel b opgenomen met de verdeling in welstandsklassen, naar leeftijdscategorie en geslacht. De categorie "onbekend" omvatte $7 \%$ van de deelnemers.

Tabel 9 geeft een overzicht van de verdeling naar onderscheiden leeftijdscategorieën en geslacht van de landelijke bevolking, de volwassen Brielse populatie, de steekproef en de uiteindelijke deelnemers. De 18-24 jarigen zijn onder de deelnemers enigszins ondervertegenwoordigd, de 35-54 jarigen licht oververtegenwoordigd.

Tot de niet-deelnemers behoren in de eerste plaats de non-respondenten, een groep van 416 personen te weten 245 mannen en 171 vrouwen. Over de redenen van het niet-reageren bestaat geen informatie. Leeftijd en geslacht van de personen uit deze groep zijn wel bekend. Tabel $\mathrm{c}$ geeft hiervan een overzicht. In de meeste leeftijdscategorieén blijken de mannen in de meerderheid. Voorts vallen onder de niet-deelnemers de personen die niet-verwerkbare gegevens leverden. Tabel c geeft van deze 55 personen een indeling naar leeftijd en geslacht. Nu blijken de vrouwen wat sterker vertegenwoordigd dan de mannen. Deze groep omvat 43 personen die volledig aan het onderzoek hadden deelgenomen doch wier gegevens om administratieve redenen niet klopten. Ook de 4 personen, die onvolledig urine verzamelden, behoren tot deze groep van 43 . De overige 12 verschaften wel alle gegevens maar leverden de 24 -uurs urine niet in.

Tot slot werden onder de niet-deelnemers de "weigeraars" gerekend, de 141 personen die actief lieten weten niet mee te zullen doen. In tabel c is ook van deze groep een overzicht gegeven naar leeftijd en geslacht. In de leeftijdsgroepen tot 60 jaar zijn het voornamelijk mannen, die afzegden, daar boven vooral vrouwen. In totaal zag een gelijk aantal mannen en vrouwen bewust van deelname af. De argumenten voor weigering waren uiteenlopend. Velen gaven op al regelmatig onder medische controle te staan. Anderen waren niet mobiel genoeg of zagen tegen de urineverzameling op. Een aantal personen deelde mee, dat zij gedurende de onderzoeksperiode niet aanwezig zouden zijn (bijvoorbeeld in 
verband met militaire dienst). Anderen bleken de envelop terug te sturen in verband met verhuizing. De overige afzeggingen zijn samen te vatten onder wat men "persoonlijke redenen" zou kunnen noemen.

In afbeelding 1 zijn de deelnemers en uiteindelijke niet-deelnemers, uitgesplitst naar leeftijd en geslacht weergegeven. Uit de leeftijdscategorie 60-64 jaar is door zowel mannen als door de vrouwen het beste meegedaan: $75 \%$. Het slechtst deden de $18-24$ jarigen mee en van dezen met name de mannen: $41 \%$. Over het totaal bezien deden vrouwen vaker mee dan mannen, respectievelijk 64 en $55 \%$.

Een respons van $72,3 \%$ mag bij een grootschalig bevolkingsonderzoek vanuit de huisartspraktijk bevredigend worden genoemd. Prins et al melden een zelfde opkomstpercentage ${ }^{247}$. Valkenburg et al rapporteren $78 \%$, Bekker geeft $66 \%$ op, Van Ree $65 \% 29,27,166$. De verdeling van de uiteindelijke deelnemers naar leeftijd en geslacht vertoont een redelijke gelijkenis met die van de Brielse bevolking. De groep 18-24 jarigen is evenwel iets onder-, die van 35-54 jarigen wat oververtegenwoordigd. De verdeling van de deelnemers naar burgelijke staat en welstandsklasse stemt overeen met die van de bevolking van Nederland.

Opmerkelijk is dat de mannen een slechtere opkomst realiseerden dan de vrouwen. Tanskanen en Bekker melden dezelfde bevinding ${ }^{78,29}$. Werkomstandigheden, maar ook eveneens regelmatige geneeskundige controles of keuringen door bedrijfsgeneeskundige diensten kunnen hieraan ten grondslag liggen.

\subsubsection{De urineverzameldag}

Van de 888 deelnemers verzamelden de meesten de urine op zondag: $37,3 \%$. Slechts weinigen deden dat op vrijdag en zaterdag, respectievelijk 1,5 en $3,4 \%$. Op maandag werd door $15,0 \%$ van de deelnemers verzameld, op dinsdag door $15,5 \%$, op woensdag door $12,7 \%$ en op donderdag door $14,6 \%$. Afbeelding 2 toont de verdeling van de verzameldagen naar geslacht. Tabel d geeft de verzameldagen naar leeftijdscategorie en geslacht weer. Beschouwt men de dagen maandag tot en met donderdag als "door de weekse" dagen en vrijdag tot en met zondag als "weekend" dagen, dan blijkt bij de mannen onder de 65 jaar een voorkeur voor de verzameling in het weekend $59,1 \%$ tegenover $40,9 \%$ door de week. Bij de vrouwelijke deelnemers uit die leeftijdscategorie ligt dat juist andersom: in thet weekend verzamelde $33,3 \%$ en op de dagen in de week $66,7 \%$. De mannelijke en vrouwelijke deelnemers boven de 65 jaar hadden een uitgesproken voorkeur voor de verzameling van de 24-uurs urine op maandag tot en met donderdag, respectievelijk 71,2 en $82,5 \%$ ten opzichte van het weekend: mannen $28,8 \%$ en vrouwen $17,5 \%$. In afbeelding 3 is een overzicht van deze gegevens weergegeven. 
Werkomstandigheden spelen kennelijk een rol bij de keuze van de urineverzameldag. Joossens et al adviseren dan ook de urine gedurende het weekend te laten verzamelen ${ }^{81}$. In het eerder aangehaalde Finse onderzoek werd altijd op zondag verzameld ${ }^{78}$.

\subsubsection{De anamnese}

Een groot aantal deelnemers geeft op een positieve anamnese voor hart - en vaatziekten te hebben, al dan niet gecombineerd met een familiaire belasting. Het gaat om $50,6 \%$ van het totaal aantal deelnemers ( $45 \%$ van de mannen en $56 \%$ van de vrouwen).

Overigens blijkt slechts $3,2 \%$ van alle deelnemers tot de groep te behoren, die zelf een hartinfarct of cerebro-vasculair accident heeft doorgemaakt. De overigen vermelden wel eens een irregulaire hartactie, dyspnoe of pijn op de borst te hebben. Van de 888 deelnemers heeft $49,4 \%$ geen eigen anamnese voor hart- en vaatziekten ( $55 \%$ mannen en $44 \%$ vrouwen). Van hen heeft 19,4\% wel een belaste familieanamnese. Tabel 10 laat dit zien. Uit het onderzoek van Van Ree bleek een belaste familieanamnese bij $25 \%$ van de deelnemers ${ }^{27}$.

Van de deelnemers vermeldde $31,6 \%$ zelf aan hypertensie te lijden of er in het verleden voor behandeld te zijn geweest, al dan niet in combinatie met een familiaire belasting. Het percentage vrouwen uit deze groep ligt duidelijk hoger dan het percentage mannen: respectievelijk 39 en $23 \%$.

De overige personen $(68,4 \%)$ hebben geen belaste anamnese $(77 \%$ van de mannen en $61 \%$ van de vrouwen). Van hen heeft $23,1 \%$ wel een belaste familieanamnese. Tabel 11 geeft dit naar geslacht weer. Fins onderzoek liet zien dat daar $58 \%$ van de onderzoekspopulatie een belaste eigen of familieanamnese voor hypertensie opgaf $\mathrm{f}^{78}$.

Van de 888 deelnemers gebruikt $7,2 \%$ diuretica, 3,6\% andere bloeddrukverlagende middelen en $4,3 \%$ een natriumbeperkt dieet. Van de mannelijke deelnemers die diuretica of andere bloeddrukverlagende middelen gebruiken, volgt $67,6 \%$ geen en $32,4 \%$ wel een natriumbeperkt dieet. In tabel 12 is, uitgesplitst naar géén en wèl dieetgebruik, het al dan niet gebruik van medicatie weergegeven. Hieruit blijkt, dat van de wrouwelijke deelnemers $78,0 \%$ naast genoemde medicatie geen en $22,0 \%$ wel een natriumbeperkt dieet volgt.

Het gebruik van diuretica of andere bloeddrukverlagende middelen alsmede het gebruik van een natriumbeperkt dieet, is in relatie tot de anamnestische gegevens laag. Hoewel het hier om anamnestische gegevens gaat, lijken er toch aanwijzingen te zijn dat de behandelingsstatus te wensen overlaat; een bevinding die aansluit bij ander onderzoek. Van Ree vond in het Nijmeegs Interventie Project (na bloeddrukmeting) eveneens 
dat tweederde van de hypertensiepatienten niet of onvoldoende werd behandeld ${ }^{27}$.

\subsection{Anthropometrie, polsfrequentie en bloeddruk}

5.2.1. Anthropometrie: het lichaamsgewicht, de lichaamslengte, de kniebreedte en de Quetelet-index

In totaal zijn van 886 deelnemers gegevens voorhanden betreffende het lichaamsgewicht, de lichaamslengte en de kniebreedte (411 mannen en 475 vrouwen). Van twee vrouwen zijn deze gegevens verloren gegaan.

Het gemiddelde gewicht wan de mannen bedraagt $77,2 \pm 9,8 \mathrm{~kg}$ en van de vrouwen $67,1 \pm 10,0 \mathrm{~kg}$. De lichaamsgewichten uitgesplitst naar leeftijd en geslacht zijn in tabel 13 weergegeven. Het verschil in lichaamsgewicht tussen mannen en vrouwen geldt voor alle vergelüjkbare leeftijdscategorieën, hoewel het bij de $65-69$ jarigen minimaal is: respectievelijk $71,9 \pm 10,1$ en $70,3 \pm 9,5 \mathrm{~kg}$.

Met de leeftijd stijgt het gemiddelde gewicht van de mannelijke deelnemers tot en met de leeftijdsgroep van 55-59 jaar. $\mathrm{Bij}$ de deelneemsters wordt een zelfde trend waargenomen, met dien verstande dat de stijging van het gemiddelde lichaamsgewicht met de leeftijd tot het 65 e jaar doorgaat.

Bij de mannen bedraagt de gemiddelde lengte $176,8 \pm 6,8 \mathrm{~cm}$ en bij de vrouwelijke deelnemers $164,8 \pm 7,0 \mathrm{~cm}$ (Tabel 13). De mannelijke deelnemers zijn in alle vergelijkbare leeftijdscategorieën langer dan de vrouwen die aan het onderzoek deelnamen. Tevens blijkt dat de mannen uit de jongste leeftijdscategorie (18-24 jaar) langer zijn dan de overige deelnemers. Dat zelfde geldt voor de vrouwen uit die leeftijdsgroep. De waarden bedragen respectievelijk $180,7 \pm 5,3$ en $168,1 \pm 6,9 \mathrm{~cm}$.

De gemiddelde (gesommeerde) waarde van de kniebreedten bedraagt bij de mannen $20,1 \pm 1,1 \mathrm{~cm}$ en bij de vrouwen $19,0 \pm 1,3 \mathrm{~cm}$ (Tabel 13). Het verschil tussen mannen en vrouwen in kniebreedte is significant. Tussen de onderscheiden leeftijdscategorieẻn bestaan echter géén significarite verschillen.

Het verschil tussen beide geslachten wordt door een verschil in lichaamsbouw verklaard.

De Quetelet-index (QI) kon bij 886 deelnemers worden berekend, 411 mannen en 475 vrouwen. Gemiddeld bedraagt deze bij de mannen $24,7 \pm 2,8$ en bij de vrouwen $24,7 \pm 3,8$ (Tabel 13). Bij de mannelijke deelnemers verschillen de QI van de eerste twee leeftijdsgroepen onderling niet significant van elkaar. Wel significant is het verschil tussen de gemiddelde $\mathrm{QI}$ van degenen jonger dan 35 jaar en die daarboven. De hoogste gemiddelde QI wordt gezien bij de 60-64 jarigen: $26,4 \pm 2,3$. Bij de 
vrouwelijke deelnemers bliken de QI waarden van de eerste twee leeftijdsgroepen onderling niet significant te verschillen. Wel verschillen deze met de QI waarden wan de daaropvolgende leeftijdscategorieën. De hoogste gemiddelde QI wordt aangetroffen bij de 60-64 jarige vrouwen: $28,7 \pm 5,2$.

Wordt een QI-score in categorieên gemaakt met waarden van: QI $\leqslant 22$, $22<\mathrm{QK}<28$ en $\mathrm{Q} \mathbb{1} \geqslant 28$ dan blijkt dat $21 \%$ van de mannelijke deelnemers in de laagste, $63 \%$ in de middelste en $16 \%$ in de hoogste categorie valt. Bij de vrouwelijke deelnemers bedragen deze percentages respectievelijk: 29,49 en $22 \%$. Binnen de categorie met een $\mathrm{QI} \geqslant 28$ blijkt $14 \%$ van de mannen en $43 \%$ van de vrouwen een $Q \mathbb{Q} \geqslant 30$ te hebben en dus duidelijk obees te zijn.

De jongste deelnemers blijken het langst. Het is bekend dat de gemiddelde lengte van jonge mannen, zoals waargenomen tijdens de keuring voor de militaire dienstplicht, nog steeds toeneemt ${ }^{248,249}$. De QI - te berekenen vanaf 1962 - is echter constant. Tabel e geeft hiervan een overzicht. Een Quetelet-index boven een bepaalde normwaarde wordt in bevolkingsonderzoek als een goede indicator voor obesitas beschouwd ${ }^{169,170,240,250,251,252}$ " De in dit onderzoek gevonden waarden komen overeen met de in de "The Milton Survey" berekende Quetelet-indices ${ }^{186}$. In het Finse onderzoek van Tanskanen werden overeenkomstige waarden gevonden ${ }^{78}$. Tevens bleek in beide studies de gemiddelde QI van de mannen en vrouwen - precies als in de onderhavige studie - overeen te komen.

Nederlands onderzoek naar de hoogte van de Quetelet-index is zowel onder kinderen als onder volwassenen uitgevoerd $169,170,240,253$. Hoewel de leeftijdscategorieën niet geheel overeenstemmen, tonen de waarden van de Quetelet-index goede overeenkomst met die uit de studies van Baecke en Deurenberg et al. Beschouwt men, zoals door Kok et al aanbevolen, een $Q I \geqslant 27$ bij mannen en een $Q I \geqslant 26$ bij vrouwen als grenswaarde voor obesitas, dan komen de Brielse prevalentiepercentages redelijk overeen met het onderzoek van genoemde auteurs ${ }^{252}$. Ook van de cijfers van Vandenbroucke verschillen de hier gevonden uitkomsten nauwelijks ${ }^{250}$. De Gezondheidsraad gaat uit van de volgende prevalentiecijfers van adipositas bij volwassenen ${ }^{170}-Q \Gamma \geqslant 30$ :

mannen $<30$ jaar: $0-8 \%, 30-50$ jaar: $2-9 \%,>50$ jaar: $3-10 \%$ vrouwen $<30$ jaar: $2-3 \%, 30-50$ jaar: $4-8 \%,>50$ jaar: $10-25 \%$.

De Brielse gegevens van de vrouwen komen hier redelijk mee overeen, die van de mannen vallen duidelijk lager uit:

mannen $<35$ jaar $1,6 \%, 35-54$ jaar: $2,3 \%,>54$ jaar: $2,7 \%$ vrouwen $<35$ jaar: $3,3 \%, 35-54$ jaar: $6,9 \%,>54$ jaar: $20,1 \%$.

Kromhout en recentelijk de Voedingsraad adviseren de Quetelet-index te handhaven op $20-25 \mathrm{~kg} / \mathrm{m}^{2254,39}$. In dat geval blijkt in dit onderzoek $39 \%$ van de mannen en $37 \%$ van de vrouwen een te hoge QI te hebben. 


\subsubsection{Polsfrequentie, systolische en diastolische bloeddruk}

Van 892 personen zijn waarden verkregen betreffende de polsfrequentie, de systolische en de diastolische bloeddruk. De vier deelnemers die de urine onvolledig verzamelden, zijn meegerekend. De gemiddelde polsfrequentie bedraagt bij de mannen $72 \pm 10,9$ en bij de vrouwen $74 \pm 10,3$ slagen per minuut $(0,001<\mathrm{P}<0,01)$. Tabel 14 geeft een overzicht van de polsfrequentie nar leeftijd en geslacht. De vrouwelijke deelnemers hebben over het algemeen een snellere pols dan de mannen. Het duidelijkst is dit bij de 18-24 jarigen. Een bevinding die ook in andere onderzoekingen is gedaan 78,186 .

De gemiddelde systolische bloeddruk bedraagt bij de mannen $132 \pm 17,2$ en bij de vrouwen $127 \pm 19,6 \mathrm{~mm} \mathrm{Hg}(\mathrm{P}<0,001)$. Tabel 14 geeft een overzicht wan de systolische bloeddruk naar leeftijd en geslacht.

De vrouwelijke deelnemers hebben in de eerste drie leeftijdscategorieën een significant lagere systolische bloeddruk dan de mannen uit die leeftijdsgroepen.

In de leeftijdscategorieën 55-59, 60-64 en 65-69 jaar verschillen de systolische bloeddrukken van mannen en vrouwen niet significant van elkaar. De vrouwen boven de 70 jaar hebben daarentegen juist een significant hoger bloeddruk dan de mannen uit die leeftijdsgroep. Bij de mannelijke deelnemers treft men in dit transversale onderzoek hogere waarden voor de bloeddruk aan met het vorderen van de leeftijd. Bij vrouwen zien wij in grote lijnen eveneens hogere systolische bloeddrukwaarden met het oplopen van de leeftijd.

Afbeelding 4 toont de procentuele verdeling van de hoogte van diverse systolische bloeddrukniveaus naar geslacht. Een procentuele verdeling van de systolische bloeddrukwaarden groter of gellik aan $\mathbb{4 0}$, 150 en 160 $\mathrm{mm} \mathrm{Hg}$ naar leeftijd en geslacht is in tabel $\mathrm{f}$ weergegeven. Over alle leeftijdscategorieën is het percentage mannen met een systolische bloeddruk van $\geqslant 140$ resp. $\geqslant 150 \mathrm{~mm} \mathrm{Hg}$ groter dan het percentage vrouwen in die bloeddrukklassen, te weten 34 versus 25 en 19 versus $14 \%$. In de klasse met een systolische bloeddruk $\geqslant 160 \mathrm{~mm} \mathrm{Hg}$ is het percentage mannen en vrouwen gelijk en wel 8.

De gemiddelde diastolische bloeddrukwaarde bedraagt bij de mannen $81 \pm 10,5$ en bij de vrouwen $80 \pm 11,0 \mathrm{~mm} \mathrm{Hg}$ (n.s.). Tabel 14 geeft een owerzicht van de diastolische bloeddrukwaarden naar leeftijd en geslacht. De mannelijke en vrouwelijke deelnemers vertonen binnen de meeste, vergelijkbare leeftijdscategorieën geen significante verschillen in de hoogte van de diastolische druk. Een uitzondering hierop vormt de groep mannelijke deelnemers van 35-54 jaar: zij hebben een significant hogere diastolische bloeddruk dan de vrouwen uit die leeftijdsgroep. De diastolische bloeddruk van de vrouwen van 70 jaar en ouder is significant hoger dan 
die van de mannen van die leeftijd. Het oplopen van de diastolische bloeddruk met de leeftijd wordt bij de mannelijke deelnemers uit dit transversale onderzoek duidelijk indien men de jongere leeftijdsgroepen vergelijkt met de 60-69 jarigen. De mannen van 70 jaar en ouder hebben daarentegen weer een iets lagere bloeddruk. Bij de vrouwelijke deelnemers zien wij eveneens een oplopen van de diastolische bloeddruk met het ouder worden.

Afbeelding 5 toont de procentuele verdeling van de hoogte van diverse diastolische bloeddrukniveaus naar geslacht. Tabel g geeft de procentuele verdeling van de diastolische bloeddruk boven het niveau van 90,100 en $110 \mathrm{~mm} \mathrm{Hg}$. Over alle leeftijden gezamenlijk is het percentage mannen met een diastolische bloeddrukwaarde $\geqslant 90 \mathrm{~mm} \mathrm{Hg}$ en $\geqslant 100 \mathrm{~mm} \mathrm{Hg}$ iets groter dan het percentage vrouwen in die bloeddrukklassen: 24 versus 22 en 6 versus $4 \%$. In de klasse van de diastolische bloeddruk $\geqslant 110 \mathrm{~mm} \mathrm{Hg}$ is het percentage mannen iets kleiner dan het percentage vrouwen, 1 versus 2 . Vergelijking met het Zoetermeerse-EPOZ-onderzoek laat een grote overeenkomst zien wat betreft de gevonden bloeddrukwaarden ${ }^{166}$. Omgerekend voor mannen en vrouwen samen van 20 jaar en ouder blijkt in het EPOZ-onderzoek dat $32,1 \%(\mathrm{n}=6431)$ van de onderzochte personen een bloeddruk heeft van systolisch $\geqslant 140 \mathrm{~mm} \mathrm{Hg} \mathrm{en/of} \mathrm{diastolisch}$ $\geqslant 90 \mathrm{~mm} \mathrm{Hg}$. In het Brielse onderzoek werd een percentage van 35,8 $(n=319)$ gevonden bij een populatie van 18 jaar en ouder.

Een bloeddruk van systolisch $\geqslant 160 \mathrm{~mm} \mathrm{Hg}$ en/of diastolisch $\geqslant 95 \mathrm{~mm}$ $\mathrm{Hg}$ werd in het Zoetermeerse onderzoek bij 13,1\% van de onderzochten en in Brielle bij 10,0\% aangetroffen. Bekker vond in Krimpen aan den IJssel bij 12\% van de deelnemers aan een hypertensie interventieonderzoek een dergelijk bloeddrukniveau $72^{29}$. In een experimenteel bloeddruk opsporingsonderzoek in Tilburg was dit aandeel zelfs $16,7 \%$ van de onderzoekspopulatie ${ }^{255}$.

Beschouwt men de onderhavige bloeddrukgegevens tegen de achtergrond van de criteria van de Gezondheidsraad ${ }^{8}$ dan blijkt voor alle deelnemers, mannen en vrouwen gezamenlijk, inclusief 122 personen van 65 jaar en ouder, de prevalentie van de diastolische waarde $\mathrm{P}$ als volgt te zijn:

$90 \mathrm{~mm} \mathrm{Hg} \leqslant \mathrm{P}<100 \mathrm{~mm} \mathrm{Hg:} \mathrm{17,6 \%}$

$100 \mathrm{~mm} \mathrm{Hg} \leqslant \mathrm{P}<115 \mathrm{~mm} \mathrm{Hg:} \mathrm{4,6 \%}$

$P \geqslant 115 \mathrm{~mm} \mathrm{Hg}: \quad 0,3 \%$

Rekent men, zoals aanbevolen in dit "Advies inzake Hypertensie" de ouderen van 65 jaar en ouder niet mee dan wordt de prevalentie:

$90 \mathrm{~mm} \mathrm{Hg} \leqslant \mathrm{P}<100 \mathrm{~mm} \mathrm{Hg:} \mathrm{14,1 \%}$

De Gezondheidsraad schat het percentage mannen en vrouwen tussen 35-65 jaar met een diastolische bloeddruk van $\geqslant 90 \mathrm{~mm} \mathrm{Hg}$, op respectie- 
velijk 38 en $35^{\circ}$. Deze percentages zijn beduidend hoger dan het in het hier beschreven onderzoek gevonden percentage.

De normen van de WHO, volgens welke van hypertensie gesproken wordt indien een systolische waarde van $\geqslant 160 \mathrm{~mm} \mathrm{Hg} \mathrm{en/of} \mathrm{een} \mathrm{diasto-}$ lische waarde van $\geqslant 95 \mathrm{~mm} \mathrm{Hg}$ wordt waargenomen, levert voor de bloeddruk $\mathrm{P}$, een vóórkomen van ${ }^{3}$ :

$\begin{array}{ll}\text { P systolisch } \geqslant 160 \mathrm{~mm} \mathrm{Hg}: & 8,0 \% \\ \text { P diastolisch } \geqslant 95 \mathrm{~mm} \mathrm{Hg}: & 8,3 \% \\ \text { P systolisch } \geqslant 160 & \\ \quad \text { en } / \text { of } & 10,0 \% \text { waarvan: } \\ \text { P diastolisch } \geqslant 95 \mathrm{~mm} \mathrm{Hg:} & \\ \text { P diastolisch } \geqslant 95 \mathrm{~mm} \mathrm{Hg} \text { en } & \\ \text { P systolisch } \geqslant 160 \mathrm{~mm} \mathrm{Hg:} & 3,1 \%\end{array}$

De WHO schat het percentage volwassenen in grote delen van de wereld met een systolische bloeddruk van $\geqslant 160 \mathrm{~mm} \mathrm{Hg}$ en/of een diastolische waarde van $\geqslant 95 \mathrm{~mm} \mathrm{Hg}$, op 8-18\% . De uitkomsten van het Brielse onderzoek stemmen hiermee overeen. Overigens zij met nadruk vermeld, dat het hier gaat om waarden welke tijdens één bezoek zijn gemeten. Herhaling van de bloeddrukmeting op andere momenten zal naar alle waarschijnlijkheid lagere systolische en diastolische uitkomsten opleveren door een regressie naar het gemiddelde effect ${ }^{8,38,247,255,256}$.

\subsection{De bepalingen in de 24-uurs urine}

\subsubsection{Volume}

Het gemiddelde volume van de verzamelde urine bedraagt bij de 411 mannen 1,5 $\pm 0,5$ liter. Bij de 477 vrouwen $1,4 \pm 0,5$ liter $(0,001<\mathrm{P}<0,01)$. Tabel 15 geeft een overzicht van de volumina uitgesplitst naar de onderscheiden leeftijdscategorieën en het geslacht. De mannelijke deelnemers uit de leeftijdsgroep 18-24 jaar hebben gemiddeld een iets kleiner urinevolume dan de daaropvolgende leeftijdscategorieèn. De oudere deelnemers, $\operatorname{van}$ 65-69 en 70 jaar en ouder, hebben weer een urinewolume vergelijkbaar met de jongere groep. Bij de vrouwelijke deelnemers vertonen de leeftijdsgroepen tot 54 jaar onderling geen significante verschillen in de omvang van het urinevolume. Ook de 55-69 jarigen hebben onderling geen significant verschil in urinevolume. De vrouwen van 70 jaar en ouder hebben een volume van de verzamelde 24 -uurs urine vergelijkbaar met de jongere leeftijdsgroepen. De gemiddelde waarden komen overeen met uitkomsten uit andere Nederlandse onderzoekingen ${ }^{257}$. 


\subsubsection{Natrium}

De gemiddelde natriumuitscheiding in de 24-uurs urine is voor de 411 deelnemende mannen $167 \pm 65,7$ en voor de 477 vrouwen $137 \pm 57,0 \mathrm{mmol}$ $(\mathrm{P}<0,001)$. Tabel 15 geeft een overzicht van de natriumexcreties naan leeftijd en geslacht.

De mannelijke deelnemers hebben een hogere natriumuitscheiding dan de vrouwen. De hoogste uitscheiding wordt gevonden bij de 60-64 jarige mannen: $185 \pm 90,0 \mathrm{mmol}$; de laagste bij de mannen van 70 jaar en ouder, $124 \pm 46,2 \mathrm{mmol}$. De groep 65-69 jarigen heeft een natriumuitscheiding van $142 \pm 51,3 \mathrm{mmol}$. Deze verschilt statistisch niet significant van die van de oudere mannen. De natriumuitscheiding in de 24-uurs urine van de eerste vier leeftijdsgroepen verschilt onderling niet significant van. De gewonden waarden kunnen worden samengevoegd tot een gewogen gemiddelde over de leeftijdscategorie van 18-64 jaar van 174 $165,7 \mathrm{mmol}$ natrium $(\mathrm{n}=352)$. Voor de oudere mannen van boven de 65 jaar vindt men $129 \pm 47,8 \mathrm{mmol}$ natrium per 24 uur $(n=59)$. Dit verschil is significant (afbeelding 6).

De vrouwelijke deelnemers uit de leeftijdscategorie 25-34 jaar blijken de hoogste natriumuitscheiding te bezitten: $145 \pm 64,0 \mathrm{mmol}$. De vrouwen van 70 jaar en ouder vertonen de laagste waarde: $108 \pm 54,2 \mathrm{mmol}$ natrium per 24 uur. De gevonden waarden bij de eerste drie leeftijdscategoriën en de vijfde leeftijdscategorie blijken overeen te komen. Deze groepen verschillen onderling statistisch niet significant. Tevens blijkt dat de groepen oudere vrouwelijke deelnemers van 55-59 jaar, 65-69 jaar en van 70 jaar en ouder onderling evenmin significante verschillen vertonen in natriumuitscheiding. Voegt men de verschillende uitkomsten van de niet-significante verschillende waarden samen, dan ontstaat voor de leeftijdsgroep 18-54 en 60-64 jaar een gewogen gemiddelde van 143 557,6 mmol natrium per 24 uur $(n=378)$. Voor de 55-59 en $65-70+$ jarigen bedraagt dit $114 \pm 48,7 \mathrm{mmol}$ natrium $(n=99)$. Dit verschil is significant (afbeelding 6).

De frequentieverdeling van de natriumuitscheiding in de 24-uurs urine naar geslacht is in afbeelding 7 weergegeven. Hieruit valt te berekenen, dat $87 \%$ van de mannen en $75 \%$ van de vrouwen meer dan $100 \mathrm{mmol}$ natrium per 24 uur uitscheøden. Boven de $200 \mathrm{mmol}$ natrium zijn deze percentages respectievelijk 26 en 13, terwijl $4 \%$ van de mannen en $1 \%$ van de vrouwen een natriumuitscheiding heeft van meer dan $300 \mathrm{mmol}$ per 24 uur (afbeelding 8).

De procentuele distributie naar leeftijd en geslacht van diverse natriumuitscheidingsniveaus wordt in afbeelding 9 getoond.

De gemiddelde natriumuitscheiding in de 24-uurs urine is bij de mannelijke deelnemers $167 \pm 65,7$ en bij de vrouwelijke deelnemers $137 \pm 57,0 \mathrm{mmol}$. 
Deze gemiddelden zijnaanzienlijk lager dan die in het eerder vermelde Finse onderzoek van Tanskanen ${ }^{78}$. Deze vond gemiddelden van respectievelijk $215 \pm 83$ en $173 \pm 68 \mathrm{mmol}$ per 24 uur. In de "Heidelberg Study" bedroeg de natriumexcretie van de deelnemende mannen $194 \mathrm{mmol}$, met een spreiding van $24-643 \mathrm{mmol}^{\mathrm{J} 60}$.

Goede overeenkomst tonen de Brielse waarden met die van Simpson et all uit Nieuw Zeeland ${ }^{186}$, Joossens et $a^{81}$ en Kesteloot et $a^{258}$ beiden uit België, Armstrong et al uit Australië ${ }^{259}$ en Bing et al ${ }^{198}$ en Dauncey et a ${ }^{83}$ beiden uit Engeland.

Aangezien de verschillende gekozen leeftijdsgroepen niet steeds precies gelijk zijn, geeft vergelijking met ander Nederlands onderzoek niet meer dan een indruk. Daenen et al ${ }^{230}$ vonden bij bejaarden en Breedveld ${ }^{226}$ bij jonge volwassen vrouwen overeenkomstige waarden. Iets hoger vallen de waarden uit in vergelijking met het onderzoek van Egger ${ }^{228}$. Gezien de verschillen tussen de onderscheiden leeftijdscategorieën, is vergelijking met het onderzoek van De Waard ${ }^{229}$ moeilijk, hoewel in grote lijnen de uitkomsten corresponderen.

De gevonden natriumgehalten in de 24-uurs urine vertonen noch bij de mannelijke, noch bij de vrouwelijke deelnemers die extreme waarden zoals die bijvoorbeeld uit Japans onderzoek blijken ${ }^{224}$. Toch is het opmerkelijk dat $87 \%$ van de mannen en $75 \%$ van de vrouwen een natriumuitscheiding in de 24-uurs urine hebben groter dan $100 \mathrm{mmol}$. Deze 100 mmol natrium, overeenkomend met 5,8 gram keukenzout, wordt door de Wereldgezondheidsorganisatie als de maximaal toelaatbare inname per dag gezien ${ }^{3,9}$. Uitgaande van een bovengrens van ongeveer $150 \mathrm{mmol}-$ zoals door de Voedingsraad wordt voorgesteld - zit $57 \%$ van de mannen en $35 \%$ van de vrouwen te hoog ${ }^{39}$.

De uitkomsten zijn, zoals te verwachten was, aanzienlijk hoger dan de natriumwaarden gevonden bij onderzoek in de niet-geindustrialiseerde landen zoals door Page op de Solomon- en Prior op de Polynesische eilanden ${ }^{180,181}$.

\subsubsection{Kalium}

De gemiddelde kaliumuitscheiding in de 24-uurs urine is bij de 411 deelnemende mannen $80 \pm 24,6$ en bij de 477 vrouwen $66 \pm 19,7$ mmol $(P<0,001)$. Tabel 15 geeft een overzicht van de kaliumuitscheiding naar leeftijd en geslacht. Het blijkt, dat de mannelijke deelnemers meer kallium uitscheiden dan de vrouwelijke.

De mannen van 60-64 jaar vertonen de hoogste kaliumuitscheiding: $96 \pm 26,9 \mathrm{mmol}$, een significant hogere waarde dan de overige uitkomsten. De mannen van 70 jaar en ouder laten de laagste uitscheiding zien: $65 \pm 19,2 \mathrm{mmol}$, deze uitkomst is significant lager dan de overige waarden 
bij de mannelijke deelnemers. De hoogten van de kaliumuitscheiding van de mannen uit de eerste vier leeftijdscategorieën komen sterk met elkaar overeen. Deze waarden blijken onderling statistisch niet significant te verschillen. De kaliumuitscheiding van de 65-69 jarige mannen wijkt hier niet vanaf. Voegt men de gevonden waarden weer samen, dan ontstaat een gewogen gemiddelde over de leeftijdscategorieën 18-59 en 65-69 jaar van $80 \pm 24,1 \mathrm{mmol}$ kalium per 24 uur $(\mathrm{n}=351)$. Dit gemiddelde is significant hoger dan het gemiddelde van de mannen van 70 jaar en ouder $65 \pm 19,2 \mathrm{mmol}(\mathrm{n}=41)$ en significant lager dan de kaliumuitscheiding van de 60-64 jarige mannen $96 \pm 26,9 \mathrm{mmol}(\mathrm{n}=19)$ (afbeelding 10).

Bij de vrouwelijke deelnemers blijken degenen, die behoren tot de leeftijdscategorie 65-69 jaar de hoogste kaliumuitscheiding te hebben: $71 \pm 17,2 \mathrm{mmol}$ per 24 uur. Overigens verschilt de hoogte van deze uitscheiding niet significant van de gevonden waarden bij de jongere deelnemers. Wel verschillen deze uitkomsten van de laagst gevonden waarde voor de kaliumuitscheiding, te weten $57 \pm 17,8 \mathrm{mmol}$ per 24 uur bij de wrouwen van 70 jaar en ouder. Voegt men de niet significant verschillende uitkomsten samen, dan ontstaat voor de leeftijdsgroep 18-69 jaar een gewogen gemiddelde van $67 \pm 19,7 \mathrm{mmol}$ kalium per 24 uur $(\mathrm{n}=434)$. Deze waarde verschilt significant van de (laagst gevonden) uitkomst bij de 70 jaar en oudere vrouwen $57 \pm 17,8 \mathrm{mmol}(\mathrm{n}=43$ ) (afbeelding 10). De procentuele verdeling van de kaliumuitscheiding in de 24-uurs urine naar geslacht is in afbeelding 11 weergegeven. Hieruit valt te berekenen, dat $81 \%$ van de mannen en $95 \%$ van de vrouwen een kaliumuitscheiding van minder dan $100 \mathrm{mmol}$ hebben. De procentuele distributie naar leeftijd en geslacht van de diverse kaliumuitscheidingsniveaus, wordt in afbeelding 12 getoond.

De gemiddelde kaliumuitscheiding in de 24-uurs urine bedraagt voor de mannelijke deelnemers $80 \pm 24,6$ en voor de vrouwellike $66 \pm 19,7$ $\mathrm{mmol}$. Globaal liggen deze waarden iets hoger dan in soortgelijk onderzoek in de geîndustria liseerde wereld. Veelal ligt de hoogte van de kaliumuitscheiding tussen de 60-70 mmol per etmaal voor mannen en 50-60 mmol voor vrouwen $81,84,186,258,259$. In Newfoundland werden kaliumwaarden gevonden tussen $37-44 \mathrm{mmol}$. Hier werd de schatting gebaseerd op chemische analyse van voedingsmiddelen ${ }^{205}$. Overigens blijkt dat de kaliumuitscheiding in de 24-uurs urine bij de mannelijke deelnemers in $81 \%$ van de gevallen en bij de vrouwelijke deelnemers zelfs in $95 \%$ van de gevallen onder de $100 \mathrm{mmol}$ ligt. De fysiologische behoefte aan kalium bedraagt 50-100 mmol per dag $46,47,48,62,260$.

De kaliumuitscheiding in het Finse onderzoek daarentegen was iets hoger: bij de mannen $91 \pm 29$ en bij de vrouwen $73 \pm 22$ mmol per 24 uur $^{78}$. Vergelijking met Nederlands onderzoek van Rookus et al laat zien, dat de 
mannelijke deelnemers in dat onderzoek een wat hogere en de vrouwen een iets lagere kaliumuitscheiding in de 24-uurs urine hadden dan in het Brielse onderzoek ${ }^{231}$.

\subsubsection{Molaire natrium/kalium ratio}

De gemiddelde molaire natrium/kalium ratio, berekend uit de natriumen kalimuitscheiding in de 24-uurs urine, is bij de mannelijke deelnemers $2,2 \pm 0,84$ en bij de vrouwelijke deelnemers $2,2 \pm 0,93$ (n.s.). Tabel 15 geeft een overzicht van de natrium/kalium ratio's naar leeftijd en geslacht.

Bij de mannelijke deelnemers hebben degenen uit de eerste en de derde leeftijdscategorie de hoogste natrium/kalium ratio, respectievelijk $2,3 \pm 0,94$ en $2,3 \pm 0,86$. De laagste ratio wordt gevonden bij de mannen in de leeftijdscategorie $65-69$ jaar en wel $1,9 \pm 0,64$. De molaire natrium $/ \mathrm{ka}-$ lium ratio van de mannelijke deelnemers uit de leeftijdsgroep 25-34 jaar komt overeen met die van de 55-59 jarigen. De oudere groepen hebben alle een wat lagere natrium/kalium ratio. Onderling verschillen deze ratio's van géén van de onderscheidlen leeftijdscategorieèn significant (afbeelding 13).

Bij de vrouwelijke deelnemers blijkt de leeftijdsgroep 25-34 jaar de hoogste natrium/kalium ratio te bezitten: 2,3 40.97 . De laagste ratio wordt gezien bij de 55-59 en 65-69 jarige vrouwen, respectievelijk $1,8 \pm 0,63$ en $1,8 \pm 0,81$. De molaire natrium/Kalium ratio's van de deelnemers uit de leeftijdscategorie 18-24 en 35-54 jaar komen met elkaar overeen. De 60-64 jarige vrouwen en degenen van 70 jaar en ouder hebben een iets lagere ratio dan de laatstgenoemden. De verschillen tussen de ratio's van de eerste drie leeftijdscategorieën blijken niet significant, evenmin als de verschillen tussen de vier laatste leeftijdsgroepen. Voegt men de niet significante waarden bijeen, dan ontstaat voor de vrouwen uit de leeftijdsgroep 18-54 jaar een gewogen gemiddelde van $2,3 \pm 0,95(n=354)$. Voor de 55-70+ jarigen bedraagt de gewogen natrium/ kalium ratio $1,9 \pm 0,79(n=123)$. Dit verschil is significant. Afbeelding 13 geeft het weer.

De procentuele verdeling van de molaire natrium/kalium ratio leert, dat $99,4 \%$ van de deelnemers een ratio heeft die groter of gelijk is an 1 , $81,6 \%$ groter of gelijk aan 2,32,3\% groter of gelijk aan 3 terwijl $8,7 \%$ zelfs een natrium/kalium ratio laat zien van groter of gelijk aan 4 . Afbeelding 14 toont een overzicht van de natrium $/ \mathrm{kalium}$ ratio van deze laatste twee groepen naar leeftijd en geslacht. Gemiddeld bedraagt de natrium/kalium ratio hier respectievelijk $3,2 \pm 0,73$ en 4,2 $\pm 0,73$. Van de $35-54$ jarige mannen heeft $40 \%$ een ratio $\geqslant 3$. Bij de $65-69$ jarigen bedraagt dit percentage 22 .

Bij de vrouwelijke deelnemers van $25-34$ jaar heeft $38 \%$ een natrium/ 
kalium ratio van $\geqslant 3$. Onder de 65-69 jarigen deelneemsters $10 \%$. Voorts blijkt hieruit dat van de 18-24 jarige mannen $12 \%$ een ratio van $\geqslant 4$ heeft. Bij de 65-69 jarige mannen komt geen natrium/kalium ratio van $\geqslant 4$ voor. Bij de vrouwelijke deelnemers van $25-34$ jaar wordt in $15 \%$, bij de oudste deelneemsters in $2 \%$ wan de gevallen een ratio van $\geqslant 4$ gevonden.

Tabel 16 geeft inzicht in de absolute hoogte van de natrium- en kaliumuitscheiding in de 24-uurs urine van de deelnemers met de laagste, hoogste en gemiddelde natrium/kalium ratio's. Hiertoe zijn uit de groep personen met een natrium/kalium ratio van $\geqslant 1$ doch $<1,5,25$ mannelijke en 25 vrouwelijke deelnemers aselect getrokken. Ook uit de deelnemers met een natrim/kalium ratio van $\geqslant 2,5 \mathrm{doch}<3$ en van degenen, met een genoemde ratio van $\geqslant 4$ zijn 25 mannen en 25 vrouwen aselect getrokken.

De gemiddelde natrium- en kaliumuitscheiding van de mannelijke deelnemers uit de laagste natrium $/ \mathrm{kalium}$ ratio categorie bedraagt respectievelijk $103 \pm 34,3$ en $89 \pm 24,9 \mathrm{mmol}$ per 24 uur. Mannelijke deelnemers uit de natrium $/$ kalium ratio categorie $\geqslant 2,5$ doch $<3$, vertonen een gemiddelde natriumuitscheiding in de 24 -uurs urine van $195 \pm 55,4$ en een kaliumexcretie van $72 \pm 22,0 \mathrm{mmol}$. De hoogste natrium/kalium ratio categorie, $\geqslant 4$ geeft absolute uitscheidingswaarden van $242 \pm 89,7 \mathrm{mmol}$ natrium en $61 \pm 21,2 \mathrm{mmol}$ kalium per 24 uur te zien.

Bij de vrouwelijke deelnemers met een natrium/kalium ratio van $\geqslant 1$ doch $<1,5$ is de gemiddelde natriumuitscheiding $84 \pm 25,6$ en de kaliumexcretie $74 \pm 16,7 \mathrm{mmol}$ per 24 uur. De vrouwelijke deelnemers uit de middelste natrium/kalium ratio groep $\geqslant 2,5$ doch $<3$, laten een gemiddelde natriumexcretie van $171 \pm 36,0$ mmol en een kaliumuitscheiding van $65 \pm 14,4 \mathrm{mmol}$ per 24 uur zien. Vrouwen met een natrium $/ \mathrm{kalium}$ ratio $\geqslant 4$, hebben gemiddeld een natriumuitscheiding van $205 \pm 74,0 \mathrm{mmol}$ en een kaliumexcretie van $50 \pm 19,1 \mathrm{mmol}$ in de 24-uurs urine. Met het eerder genoemde, geringe leeftijdseffect op de hoogte van de natrium/kalium ratio onder de vrouwelijke deelnemers, is geen rekening gehouden. Aangezien er geen significant verschil bestaat tussen de hoogten van de natrium/kalium ratio's van de mannelijke en vrouwelijke deelnemers, zijn in tabel 16 tevens de gecombineerde gegevens opgenomen. Hieruit blijkt, dat bij de personen met een hoge natrium/kalium ratio het absolute natriumgehalte in de 24-uurs urine significant hoger is dan bij de deelnemers met een lage ratio. Het kaliumgehalte in de 24-uurs urine is bij de deelnemers met een hoge natrium/kalium ratio juist significant lager dan bij degenen met een lage ratio. Afbeelding 15 geeft het weer.

De molaire natrium/kalium ratio, berekend uit de gevonden waarden van de natrium-en kaliumuitscheiding in de 24-uurs urine bedraagt zowel bij de mannen als bij de vrouwen $2,2 \pm 0,89$. Deze waarde vertoont overeenkomst met die uit de meeste andere studies in de geïndustrialiseerde 
wereld ${ }^{78,186,258}$. Hoewel onderzoek uit Newfoundland ${ }^{205}$, Korea ${ }^{68}$ en Noord-Japan ${ }^{67}$ waarden van 3,2 tot 6,5 laat zien. Een hoog percentage deelnemers (32\%) aan het Brielse onderzoek laat echter eveneens een natrium/kalium ratio zien van groter of gelijk aan 3 .

\subsubsection{Calcium}

De gemiddelde calciumuitscheiding in de 24-uurs urine bedraagt bij de 410 mannelijke deelnemers, bij wie betrouwbare bepalingen konden worden gedaan, $5,0 \pm 2,30 \mathrm{mmol}$ en bij de 476 vrouwelijke deelnemers $4,2 \pm 2,19 \mathrm{mmol}(\mathrm{P}<0,001)$. Tabel 17 geeft een overzicht van de calciumuitscheiding in de 24-uurs urine naar leeftijd en geslacht. Bij één man en één vrouw zijn de gegevens verloren gegaan.

$\mathrm{Bij}$ de mannen is de calciumuitscheiding het hoogst bij de deelnemers uit de leeftijdsgroep $35-54$ jaar: 5,5 2,27 mmol. De laagste waarde wordt gezien bij de mannen van 70 jaar en ouder: $3,3 \pm 2,06 \mathrm{mmol}$ calcium per 24 uur. Bij de jongere deelnemers tot 35 jaar komen de calciumwaarden met elkaar overeen. De verschillen zijn niet significant. De calciumuitscheiding van de mannen uit de daarop volgende leeftijdscategorieën liggen iets hoger. Deze verschillen zijn onderling evenmin significant. De oudste deelnemers - 65-69 en $70+$ jaar - hebbem de laagste calciumuitscheiding en verschillen onderling ook al niet. Voegt men de verschillende groepen samen dan ontstaan gewogen gemiddelden, welke onderling wel significant verschillen: $18-34$ jaar $4,8 \pm 2,12 \mathrm{mmol}$ calcium $(\mathrm{n}=121), 35-64$ jaar $5,4 \pm 2,30 \mathrm{mmol}$ calcium $(n=230)$ en $65-70+$ jaar $3,6 \pm 2,07 \mathrm{mmol}$ calcium $(\mathrm{n}=59)$ per 24 uur. Afbeelding 16 geeft het weer.

Bij de vrouwelijke deelnemers vertonen degenen uit de leeftijdscategorie 60-64 jaar de hoogste calciumuitscheiding: 4,5 22,36 mmol per 24 uur. De laagste waarden worden gevonden bij de vrouwen van 70 jaaren ouder: $3,0 \pm$ $1,86 \mathrm{mmol}$. Ook de 65-69 jarigen vertonen een lage calciumuitscheiding, statistisch niet verschillend van de oudste deelneemsters. De calciumuitscheidingen van de deelneemsters uit de eerste vijf leeftijdscategorieën vertonen onderling geen significante verschillen. Voegt men deze verschillende groepen samen, dan ontstaat voor de vrouwelijke deelnemers uit de leeftijdsgroep 18-64 jaar een gewogen gemiddelde van 4,3 $\pm 2,17 \mathrm{mmol}$ calcium per 24 uur $(n=413)$. Voor de ouderen, $65-70+$ jaar $3,2 \pm 1,85$ $\mathrm{mmol}$ calcium per 24 uur $(\mathrm{n}=63)$. Dit verschil is statistisch significant (afbeelding $\llbracket 6$ ).

Het aantal studies naar de hoogte van de calciumuitscheiding is beperkt. In het Nieuwzeelandse onderzoek ${ }^{186}$ werden gemiddelde calciumwaarden in de 24-uurs urine gevonden, die een goede overeenkomst vertonen met de Brielse gegevens. De calciumuitscheiding bedroeg bij de mannen $4,7 \pm 2,5$ en bij de vrouwen $3,6 \pm 1,9 \mathrm{mmol}$ per 24 uur. Ook deze 
auteurs namen een variatie naar leeftijd en geslacht waar. Joossens et al wonden in Belgie hogere calciumwaarden, bij de mannen gemiddeld

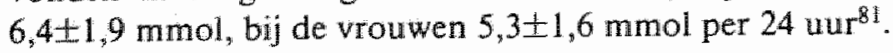

\subsubsection{Magnesium}

De magnesiumuitscheiding in de 24-uurs urine is bij 410 mannen en 476 wrouwen bepaald (twee waarden gingen verloren) en bedraagt gemiddeld respectievelijk $4,9 \pm 1,68$ en $4,1 \pm 1,43 \mathrm{mmol}(\mathrm{P}<0,001)$. Tabel 17 geeft een overzicht van de magnesiumuitscheiding in de 24-uurs urine naar leeftijd en geslacht.

Bij de mannelijke deelnemers laten degenen uit de leeftijdscategorie 55-59 jaar de hoogste uitscheiding van magnesium zien: $5,3 \pm 1,43 \mathrm{mmol}$. De laagste uitscheiding wordt gevonden onder de mannen uit de leeftijdsgroep 70 jaar en ouder: 4,0土1,21 mmol magnesium per 24 uur. Het verschil tussen deze twee uiterste waarden is significant. Hoewel de waarde bij de 65-69 jarigen duidelijk lager is dan bij de daaraanvoorafgaande leeftijdscategorieën, verschillen al deze uitkomsten onderling niet significant. Voegt men deze waarden samen, dan ontstaat voor de mannen uit de leeftijdscategorie 18-69 jaar een gewogen gemiddelde van $5,0 \pm 1,69 \mathrm{mmol}$ magnesium per 24 uur $(n=369)$. Deze waarde is significant hoger dan de magnesiumuitscheiding bij de mannen van 70 jaar en ouder, $4,0 \pm 1,21 \mathrm{mmol}$ per 24 uur ( $n=41$ ) (afbeelding 17).

De vrouwelijke deelnemers uit de leeftijdsgroep 65-69 jaar vertonen de hoogste magnesiumuitscheiding: 4,3 1 1,39 mmol per 24 uur. De laagste waarde wordt gevonden bij de groep, die daar direct op volgt, de vrouwen van 70 jaar en ouder: $3,3 \pm 1,31$ mmol. Dit verschil is significant. De overige waarden van de magnesiumuitscheiding komen grotendeels overeen en verschillen niet significant van de hoogst gevonden waarde. Samenvoeging van deze uitkomsten levert een gewogen gemiddelde op voor de leeftijdsgroep van 18-69 jaar van 4,1土1,41 mmol magnesium per 24. uur $(n=433)$. Het verschil met de laagst gevonden magnesiumuitscheidingswaarde bij de vrouwen van 70 jaar en ouder, $3,3 \pm 1,31 \mathrm{mmol}$ $(\mathrm{n}=43$ ), is significaint (afbeelding 17).

De magnesiumuitscheidingswaarden in het eerder vermelde Nieuwzeelandse onderzoek vertonen goede overeenkomst met de Brielse waarden - mannen: $4,9 \pm 1,9$ en vrouwen: $3,9 \pm 1,4 \mathrm{mmol}^{186}$. In het Belgische onderzoek bedroegen deze waarden achtereenvolgens $4,4 \pm 0,87$ en $3,8 \pm 0,74 \mathrm{mmol}_{\text {, vergelijkbaar met die in de onderhavige studie }}^{8.1}$. Overigens zijn de magnesiumuitscheidingswaarden, net als die van calcium slechts in beperkte mate een afspiegeling van de dagelijkse inneming, zoals reeds in paragraaf 2.3 . is gesteld. 


\subsubsection{Creatinine}

De gemiddelde creatinineuitscheiding in de 24-uurs urine bedraagt bij de 410 mannelijke deelnemers $15,6 \pm 3,44 \mathrm{mmol}$ en bij de 476 vrouwelijke deelnemers $11,6 \pm 2,48 \mathrm{mmol}(\mathrm{P}<0,001)$. Tabel 18 geeft een overzicht van de creatinineuitscheiding naar leeftijd en geslacht (twee waarden ontbreken).

De hoogste uitscheiding bij de mannen wordt gevonden in de groep van 18-24 jarigen: $16,6 \pm 4,24 \mathrm{mmol}$ per 24 uur. De laagste bij de oudste deelnemers van 70 jaar en ouder: $11,5 \pm 2,47 \mathrm{mmol}$ creatinine per 24 uur. Ook de deelnemers uit de leeftijdsgroep 65-69 jaar $(13,5 \pm 1,03 \mathrm{mmol})$ tonen een lagere uitkomst dan de jongere deelnemers. De creatinineuitscheiding in de 24-uurs urine van de deelnemers tot 65 jaar ziet er betrekkelijk constant uit; de waarden verschillen onderling niet significant van elkaar. Voegt men deze uitkomsten samen, dan ontstaat voor de leeftijdscategorie 18-64 jaar een gewogen gemiddelde van $16,2 \pm 3,18 \mathrm{mmol}$ creatinine $(n=351)$. Deze waarde is significant hoger dan de creatinineuitscheiding van de mannen van 65-69 jaar $(13,5 \pm 2,03$ mmol $(n=18)$ ) en vanzelfsprekend eveneens hoger dan de creatinineuitscheiding van de oudste deelnemers $(11,5 \pm 2,47 \mathrm{mmol}(\mathrm{n}=41)$ ) (afbeelding 18).

Bij de vrouwelijke deelnemers wordt de hoogste creatininewaarde in de 24-uurs urine eveneens gevonden bij de 18-24 jarigen $(12,2 \pm 2,42 \mathrm{mmol})$ en bij de 25-34 jarige vrouwen (12,2 $2,45 \mathrm{mmol}$ per 24 uur). De laagste waarde wordt gezien bij de oudste vrouwen van 70 jaar en ouder $(9,0 \pm 2,93 \mathrm{mmol})$. Met de leeftijd lijkt bij de vrouwen de hoogte van de creatinineuitscheiding geleidelijk te dalen. De verschillen zijn onderling echter niet significant. De eerste twee leeftijdsgroepen verschillen wel met de 65-69 jarigen. Voegt men de waarden samen, dan ontstaat er voor de 18-64 jarige vrouwen een gewogen gemiddelde van $11,9 \pm 2,26 \mathrm{mmol}$ creatinine per 24 uur $(n=413)$. Deze waarde verschilt significant van de creatinineuitscheiding van de oudste deelneemsters, $9,0 \pm 2,93 \mathrm{mmol}(\mathrm{n}=43)$ doch niet van de gemiddelde uitscheiding van de 65-69 jarigen. Deze laatste uitkomst, $10,8 \pm 1,71 \mathrm{mmol}(\mathrm{n}=20)$ verschilt significant van die van vrouwen van 70 jaar en ouder (afbeelding 18).

De gemiddelde creatinineuitscheiding vertoont zowel bij de mannen als bij de vrouwen een grote overeenkomst met het onderzoek in NieuwZeeland ${ }^{186}$. In die studie bedroegen deze waarden respectievelijk $16,1 \pm 5,40$ en $11,3 \pm 3,16$ mmol creatinine per 24 uur. Ook het Belgische onderzoek laat creatininegemiddelden zien, die goed overeenkomen met de resultaten van het Brielse onderzoek; bij mannen: 16,2 en bij vrouwen $11,3 \mathrm{mmol}$ per 24 uur $^{81}$. Ander Belgisch onderzoek gaf soortgelijke uitkomsten te zien: $15,9 \mathrm{mmol}$ bij mannen en 11,6 bij vrouwen ${ }^{189}$. Het Finse 
onderzoek laat enigszins lagere waarden zien. Bij de mannen gemiddeld $13,2 \pm 3,9$ en bij de vrouwen $9,2 \pm 2,7$ mmol creatinine per 24 uur $^{78}$.

\subsubsection{Molaire natrium/creatinine ratio}

De molaire natrium/creatinine ratio, berekend uit de natrium- en creatinineuitscheiding in de 24-uurs urine bedraagt gemiddeld bij de mannen $10,9 \pm 3,89$ en bij de vrouwelijke deelnemers $11,9 \pm 4,38(\mathrm{P}<0.001)$. Tabel 18 geeft een overzicht van de gemiddelde natrium/creatinine ratio's naar leeftijd en geslacht.

Bij de mannelijke deelnemers wordt de hoogste waarde gevonden bij personen van 60-64 jaar: 11,5 $\pm 5,61$. De laagste waarde wordt gevonden bij de mannen uit de leeftijdsgroep $25-34$ jaar: $10,2 \pm 3,17$. Overigens stemmen de uitkomsten van alle leeftijdscategorieën zowel voor mannen als vrouwen goed met elkaar overeen. Het blijkt, dat de verschillen bij de onderscheiden leeftijdsgroepen niet significant zijn. Afbeelding 19 illustreert dit voor mannen en vrouwen.

De hoogste waarde wordt bij de vrouwellijke deelnemers gezien bij de 60-64 jarigen: $12,7 \pm 4,09$. De laagste uitkomst wordt gezien bij de $65-69$ jarigen: $11,3 \pm 5,20$.

Het verschil tussen de gemiddelde waarden van mannen en vrouwen, is wel significant. De gemiddelde ratio vertoont overeenkomst met de door Staessen et al gevonden uitkomsten ${ }^{189}$.

\subsubsection{Molaire kalium/creatinine ratio}

De gemiddelde molaire kalium/creatinine ratio bedraagt bij de 410 mannelijke deelnemers $5,2 \pm 1,66$ en bij de 476 vrouwelijke deelnemers $5,8 \pm 1,55(P<0,001)$. Tabel 18 geeft een overzicht van de gemiddelde molaire kalium/creatinine ratio's naar leeftijd en geslacht.

Bij de mannelijke deelnemers worden de hoogste waarden gevonden bij degenen uit de leeftijdsgroepen 60-64 en 65-69 jaar, respectievelijk $6,0 \pm 1,74$ en $6,0 \pm 2,92$. De laagste waarden worden waargenomen bij de 18-24 jarigen: $4,9 \pm 1,48$ en bij de $25-34$ jarigen: $4,9 \pm 1,36$. De uitkomsten van de overige ratio's verschillen niet significant van de hoogst gevonden waarden. Voegt men vervolgens de eerste twee leeftijdscategorieèn samen, dan ontstaat voor de 18-34 jarige mannen een gewogen gemiddelde voor de molaire $\mathrm{kalium} / \mathrm{creatinine}$ ratio van $4,9 \pm 1,41 \quad(\mathrm{n}=121)$. Combineert men de overige vijf leeftijdsgroepen, dan ontstaat voor de mannen van 35-70+ jaar een gewogen gemiddelde voor de kalium/creatinine ratio van $5,3 \pm 1,65(\mathrm{n}=289)$. Het verschil tussen genoemde ratio's is significant (afbeelding 20).

Bij de vrouwelijke deelnemers worden de hoogste waarden gevonden 
bij degenen uit de leeftijdsgroep van $65-69$ jaar: $6,7 \pm 1,50$ en de laagste bij de 25-34 jarige vrouwen: $5,4 \pm 1,52$. De molaire kalum/creatinine ratio's van de eerste drie leeftijdsgroepen komen sterk overeen. Ook de gevonden waarden bij de oudere deelneemsters vertonen overeenkomst met elkaar en verschillen onderling evenmin significant. Samenvoeging levert voor de 18-54 jarigen een gewogen gemiddelde van $5,5 \pm 1,49(n=353)$ op voor de molaire kalium/creatinine ratio. Combinatie van de uitkomsten van de oudere deelneemsters laat voor de vrouwen van 55 jaar en ouder een gewogen gemiddelde zien van $6,5 \pm 1,55(n=123)$. Het werschil tussen beide gemiddelden is significant (afbeelding 20 ).

\subsubsection{Natrium per kilogram lichaamsgewicht}

De gemiddelde natriumuitscheiding per kilogram lichaamsgewicht per 24 uur, bedraagt bij de 408 mannelijke deelnemers $2,2 \pm 0,80$ en bij de 474 vrouwelijke deelnemers $2,1 \pm 0,86$. Dit verschil blijkt niet significant. Tabel 19 geeft een overzicht.

De mannelijke deelnemers uit de leeftijdsgroep 60-64 jaar blijken de hoogste natriumuitscheiding per $\mathrm{kg}$ lichaamsgewicht (l.g.) te hebben: $2,3 \pm 1,02$. De mannen van 70 jaar en ouder, de laagste: $1,7 \pm 0,62 \mathrm{mmol}$ natrium per $\mathrm{kg} \mathrm{l.g.} \mathrm{De} \mathrm{waarden} \mathrm{uit} \mathrm{de} \mathrm{eerste} \mathrm{zes} \mathrm{leeftijdscategorieën}$ komen goed overeen en verschillen onderling niet significant. Voegt men deze samen, dan ontstaat voor de leeftijds groep 18-69 jaar een gewogen gemiddelde van $2,2 \pm 0,80 \mathrm{mmol}$ natrium per $\mathrm{kg} \mathrm{l}_{\mathrm{gg}}(\mathrm{n}=370)$. Het verschil tussen deze waarde en de gevonden uitkomst bij de mannen van 70 jaar en ouder, $1,7 \pm 0,62(n=38)$ is significant (afbeelding 21).

Bij de vrouwelijke deelnemers blijken degenen uit de leeftijdsgroep 18-24 jaar de hoogste en de 70 jaar en ouderen de laagste natriumuitscheiding per $\mathrm{kg} \mathrm{l.g.} \mathrm{te} \mathrm{hebben,} \mathrm{respectievelijk} 2,3 \pm 0,81$ en $1,6 \pm 0,73$ mmol natrium per $\mathrm{kg} \mathrm{l.g.} \mathrm{De} \mathrm{waarden} \mathrm{uit} \mathrm{de} \mathrm{eerste} \mathrm{drie} \mathrm{leeftijdscate-}$ gorieën komen goed met elkaar overeen en verschillen niet significant. Evenmin zijn de verschillen tussen de natriumuitscheidingen per $\mathrm{kg} \mathrm{l} . \mathrm{g}$. van de overige leeftijdscategorieën significant. Het gewogen gemiddelde van de jongere leeftijdsgroepen, 18-54 jaar bedraagt 2,2 $\pm 0,87 \mathrm{mmol}$ natrium per $\mathrm{kg} \mathrm{l.g.}(\mathrm{n}=354)$. Voor de $55-70+$ jarigen ontstaat een gewogen gemiddelde van $1,7 \pm 0,69$ mmol natrium per $\mathrm{kg} \mathrm{l.g.}(\mathrm{n}=120)$. Het verschil tussen beide gemiddelden is sterk significant (afbeelding 21).

\subsubsection{Kalium per kilogram lichaamsgewicht}

De gemiddelde kaliumuitscheiding per kilogram lichaamsgewicht bedraagt bij de 408 mannelijke deelnemers $1,0 \pm 0,33$ en bij de 474 vrouwelijke deelnemers $1,0 \pm 0,31 \mathrm{mmol}$ kalium per $\mathrm{kg} \mathrm{l.g}$. (n.s.). Tabel 19 geeft 
een overzicht van de kaliumuitscheiding per $\mathrm{kg}$ l.g. naar leeftijd en geslacht.

De mannelijke deelnemers uit de leeftijdsgroep 60-64 jaar blijken de hoogste kaliumwaarde per $\mathrm{kg}$ l.g. te hebben: $1,2 \pm 0,31$ en de mannen van 70 jaar en ouder de laagste: $0,9 \pm \mathrm{mmol}$ kalium per $\mathrm{kg}$ l.g. De waarden uit de wier eerste leeftijdscategorieën komen met elkaar overeen en verschillen onderling niet significant. Voegt men deze samen, dan ontstaat voor de leeftijdsgroep 18-59 jaar een gewogen gemiddelde van $1,0 \pm 0,30$ mmol kalium per $\mathrm{kg} \mathrm{l.g.}(n=333)$. Ook de leeftijdsgroepen 60-64 en 65-69 verschillen niet significant in hoogte van de kaliumuitscheiding per $\mathrm{kg}$ l.g. Voegt men deze samen, dan ontstaat voor de 60-69 jarigen een gewogen gemiddelde van $1,2 \pm 0,47 \mathrm{mmol}$ kalium per $\mathrm{kg} \mathrm{1.g.}(n=37)$. De twee gemiddelden verschillen significant van elkaar. Tevens verschillen de gevonden waarden ieder afzonderlijk significant van de laagst gevonden waarde bij de mannen van 70 jaar en ouder, $0,9 \pm 0,24 \mathrm{mmol}$ per $\mathrm{kg} \mathrm{l.g}$. $(\mathrm{n}=38)$ (afbeelding 22).

Bij de vrouwelijke deelnemers blijkt de leeftijdsgroep 18-24 jaar de hoogste kaliumuitscheiding per $\mathrm{kg} . \mathrm{l} . \mathrm{g}$. te hebben: $1,1 \pm 0,34 \mathrm{mmol} \mathrm{kalium}$ per kg l.g. De laagste waarde wordt gevonden bij de oudste deelnemers, $0,8 \pm 0,24 \mathrm{mmol}$ kalium per $\mathrm{kg} \mathrm{l.g.} \mathrm{De} \mathrm{waarden} \mathrm{uit} \mathrm{de} \mathrm{leeftijdsgroepen} \mathrm{tot}$ 60 jaar en de 65-69 jarigen komen overeen en verschillen niet significant. Ook de vrouwen uit de leeftijdsgroepen 60-64 en 70 jaar en ouder verschillen onderling niet significant van elkaar. Het gewogen gemiddelde bij de leeftijdsgroepen $18-59$ en $65-69$ jaar bedraagt 1,0 $00,31 \mathrm{mmol}$ kalium per kg l.g. $(n=410)$. Bij de tweede groep, 60-64 en $70+$ jaar, $0,9 \pm 0,26 \mathrm{mmol}$ kalium per $\mathrm{kg} \mathrm{l.g} .(\mathrm{n}=64)$. Het verschil tussen beide gemiddelden is sterk significant (afbeelding 22).

\subsection{Invloed van de onafhankelijke op de afhankelijke variabelen}

Zoals in paragraaf 4.3. is uiteengezet, zijn de factoren: geslacht, leeftijd, urineverzameldag, welstandsklasse, burgerlijke staat, anamnese voor hart- en vaatziekten, gebruik van een natriumbeperkt dieet, gebruik van diuretica en andere antihypertensiva en anamnese voor hoge bloeddruk, als onafhankelijke variabelen in thet onderhavige onderzoek ingevoerd.

Naast de diverse 24-uurs urine parameters werden het lichaamsgewicht, de lichaamslengte, de som der knie-breedten, de Quetelet-index, de polsfrequentie, de systolische en diastolische bloeddruk als afhankelijke variabelen aangemerkt.

Tabel 20 geeft de invloed van de diverse onafhankelijke variabelen op de hoogte van de afhankelijke variabelen weer. Van de onafhankelijke variabelen met een significante invloed zijn de percentages verklaarde variantie weergegeven. Het blijkt allereerst dat de genoemde percentages, 
over het algemeen bijzonder laag zijn. Voorts is duidelijk, zoals reeds uit de woorafgaande paragrafen is gebleken, dat de leeftijd en het geslacht in nagenoeg alle gevallen hun invloed doen gelden. De praktische relevantie van de gevonden significante invloeden is overigens niet altijd duidelijk. Zo ontbreekt ogenschijnlijk de logica van de invloed van het hebben van een belaste anamnese voor hypertensie op de kniebreedte. Van de andere kant is het van belang dat men zich realiseert, dat bijvoorbeeld bij de presentatie van de bloeddrukgegevens (in paragraaf 5.2.2.) degenen met het gebruik van een natriumbeperkt dieet en met een belaste anamnese voor hart- en vaatziekten en hypertensie (onafhankelijke variabelen met een significante invloed op de systolische bloeddruk) zijn inbegrepen. In dit verband is het tevens van belang te zien dat het gebruik van antihypertensieve medicatie geen significante invloed heeft op de hoogte van de bloeddruk in vergelijking met de overige waarnemingen. Met andere woorden: degenen, die genoemde medicatie gebruiken, hebben geen ander bloeddrukwaarden dan de deelnemers zonder medicijnen. Dit kan op een goed behandelingsresultaat duiden. In het geval van de natriumuitscheiding onderscheiden degenen met een natriumbeperkt dieet zich niet van de overige deelnemers, hetgeen op een slechte compliantie wijst.

Uit tabel 20 blijkt voorts, zoals al in de desbetreffende paragrafen is besproken, dat de onafhankelijke variabele geslacht geen invloed heeft op de hoogte van de Quetelet-index, op de natriumuitscheiding per $\mathrm{kg}$ lichaamsgewicht en op de molaire natrium $/ \mathrm{kalium}$ ratio. De variabele leeftijd heeft geen invloed op de polsfrequentie en op de molaire natrium/creatinine ratio. De invloed van de dag waarop de urine is verzameld is gering.

De overige onafhankelijke variabelen blijken geen invloed uit te oefenen op de urine-excretiewaarden - dit in tegenstelling tot andere onderzoekingen (paragraaf $4.3 .23,26$ ).

Uit het bovenstaande wordt duidelijk hoe gecompliceerd de interpretatie van onderzoeksgegevens als deze is. Strikt genomen mogen immers slechts uit één tabel, samengesteld op grond van alle "significante" onafhankelijke variabelen, conclusies worden getrokken ten aanzien van hun invloed op de afhankelijke variabele in kwestie. Zulks om - zoals in paragraaf 4.3. is uiteengezet - verstrengeling van significante invloeden te voorkómen. Zo zou - om een woorbeeld te noemen - in het geval van de systolische bloeddruk én tabel moeten worden gevormd naar die onafhankelijke variabelen, die een significante invloed blijken te hebben op deze afhankelijke variabele: geslacht, leeftijd, welstandsklasse, anamnese voor hart- en vaatziekten, gebruik natriumbeperkt dieet en anamnese voor hypertensie. Tevens dienen al 
deze onafhankelijke variabelen nog in de - in tabel 5 - onderscheiden categorieën te worden verdeeld. Slechts binnen zo'n tabel mag met behulp van een $t$-toets berekend worden waar zich de significante verschillen in systolische bloeddrukhoogte bevinden.

Van deze opzet is afgezien op grond van de volgende overwegingen:

a. het aantal waarnemingen per cel zullen bij een dergelijke uitsplitsing van gegewens te klein worden om gegronde uitspraken te kunnen doen; veel cellen zullen geheel leeg blijven,

b. de presentatie van een dergelijke tabel met zoveel onafhankelijke variabelen, is buitengewoon onoverzichtelijk,

c. de percentages verklaarde variantie zijn zo klein dat zij verwaarlozing van een aantal factoren (hoewel van significante invloed) rechtvaardigen.

Op grond van de aanname dat leeftijd en geslacht belangrijke verklarende factoren zijn voor de afhankelijke variabelen in kwestie, zijn de parameters dan ook steeds naar deze twee factoren getabelleerd. Binnen de aldus gepresenteerde gegevens zijn evenwel nog significante leeftijdsinvloeden aanwezig. Formeel gezien mogen dan ook geen marginale gemiddelden worden berekend. In paragraaf 4.3. is hierop reeds gewezen. Aan dit bezwaar is tegemoet gekomen door, althans bij de afhankelijke variabelen uit de 24-uurs urine, gewogen gemiddelden te bepalen op grond van leeftijdscategorieën die onderling niet significant van elkaar verschillen. Deze waarden zijn, tevens uitgesplitst naar geslacht, grafisch weergegeven. Zoals reeds uiteengezet, zouden deze - in het geval wan de natriumuitscheiding - eigenlijk ook nog voor de verzameldag moeten worden gecorrigeerd, met genoemde bezwaren van dien.

\subsection{Samenhang Quetelet-index met de natrium-en kaliumuitscheiding, de molaire natrium/kalium ratio en de bloeddruk}

De samenhang tussen de hoogte van de Quetelet-index en de natriumen kaliumuitscheiding in de 24-uurs urine en de systolische en diastolische bloeddruk is eveneens door middel van inorthogonale variantie-analyse nagegaan. Hieruit blijkt, dat een stijging van de QI met één eenheid samengaat met een hogere natriumuitscheiding van gemiddeld $5 \mathrm{mmol}$ per 24 uur en kaliumuitscheiding van 0,77 mmol per 24 uur in de urine. Deze significante samenhang is onafhankelijk van de leeftijd en het geslacht. Evenzo laat een stijging van de QI met één eenheid, een toename van de systolische bloeddruk met $1,37 \mathrm{~mm} \mathrm{Hg}$ en van de diastolische bloeddruk met $0,81 \mathrm{~mm} \mathrm{Hg}$ zien.

Ter nadere precisering van de invloed van de QI op de hoogte van de genoemde parameters, alsmede op de molaire natrium/kalium ratio, is een $\mathrm{QI}$ indeling in drie categorieën gemaakt. Te weten $\mathrm{I}: \mathrm{QI} \leqslant 22$, II: 
$22<\mathrm{QI}<28$ en III: $\mathrm{QI} \geqslant 28$. Bij de mannelijke deelnemers waren de groepen als volgt verdeeld:
I: Quetelet-index
$20,8 \pm 1,3 \quad(\mathrm{n}=86)$
II: Quetelet-index
$24,9 \pm 1,3 \quad(n=256)$
III: Quetelet-index
$29,0 \pm 1,5 \quad(\mathrm{n}=66)$
Bij de vrouwelijke deelnemers:
I: $\quad$ Quetelet-index
$20,8 \pm 1,2 \quad(\mathrm{n}=136)$
II: Quetelet-index
$24,6 \pm 1,4 \quad(n=232)$
III: Quetelet-index
$30,4 \pm 2,8 \quad(n=103)$

Per Ql categorie is gekeken naar de hoogte van de natriumuitscheiding. De gemiddelde natriumuitscheiding in de 24-uurs urine van de mannelijke deelnemers uit de categorie I bedraagt $134 \pm 47,4 \mathrm{mmol}$. Uit de categorie II, $171 \pm 63,7 \mathrm{mmol}$ terwijl de natriumexcretie bij de mannen uit QI groep III, $197 \pm 76,5 \mathrm{mmol}$ bedraagt. Men ziet een hogere natriumuitscheiding in de 24-uurs urine bij een hogere QI. Bij de vrouwelijke deelnemers blijkt dit eveneens. Zo bedraagt de gemiddelde natriumuitscheiding $132 \pm 47,3 \mathrm{mmol}$ per 24 uur bij de vrouwen met een QI uit groep I. Voor groep II is deze $135 \pm 58,8 \mathrm{mmol}$ en voor groep III, $149 \pm 63,8$ mmol natrium per 24 uur. Tabel 21 geeft hiervan een overzicht.

Per QI categorie is eveneens gekeken naar de hoogte van de kaliumuitscheiding in de 24-uurs urine. De gemiddelde kaliumuitscheiding bedraagt bij de mannelijke deelnemers uit categorie I $72 \pm 26,9 \mathrm{mmol}$, uit categorie II, $81 \pm 23,9 \mathrm{mmol}$ terwijl de kaliumuitscheiding bij de mannen uit de categorie III $85 \pm 22,5 \mathrm{mmol}$ bedraagt. Men ziet een verschil in kaliumuitscheiding in de 24-uurs urine tussen enerzijds de lagste en anderzijds de beide hogere categorieën.

Ook bij de vrouwelijke deelnemers blijkt een dergelijk verband te bestaan, zij het alleen bij de laagste en de middelste categorie. De vrouwelijke deelnemers uit de QI categorie III verschillen niet in de hoogte van de kaliumuitscheiding ten opzichte van categorie II. De kaliumwaarden bedragen bij de vrouwen uit categorie I $65 \pm 19,1 \mathrm{mmol}$, uit categorie II $67 \pm 20,3 \mathrm{mmol}$ en uit categorie III eveneens $67 \pm 19,2 \mathrm{mmol}$. Tabel 21 geeft hiervan een overzicht.

Ook de hoogte van de natrium $/ \mathrm{kalium}$ ratio is per QI categorie berekend. Bij de mannelijke deelnemers bedraagt deze ratio $2,0 \pm 0,83$ bij degenen, uit categorie I. De mannen uit de QI categorie II hebben een natrium/kalium ratio van $2,2 \pm 0,80$ terwijl degenen uit categorie III een ratio van $2,4 \pm 0,96$ laten zien. Met het oplopen van de QI wordt de molaire natrium/kalium ratio iets ongunstiger. Bij de vrouwelijke deelnemers is dat eveneens het geval, zij het slechts bij de derde categorie. De molaire natrium/kalium ratio bedraagt bij de vrouwen uit categorie I $2,2 \pm 0,88$, categorie II $2,1 \pm 0,96$ en bij de categorie III $2,3 \pm 0,95$ (tabel 21). 
Bij de eerste en de derde categorie van de QI (I en III) is berekend hoe hoog de systolische en de diastolische bloeddrukken zijn van de deelnemende mannen en vrouwen.

De mannen met een QI uit de categorie I hebben een gemiddelde systolische bloeddruk van $126 \pm 15,2 \mathrm{~mm} \mathrm{Hg}$, de mannen uit de categorie III, $140 \pm 16,4 \mathrm{~mm} \mathrm{Hg}$. De diastolische waarden bedragen respectievelijk $76 \pm 10,4 \mathrm{~mm} \mathrm{Hg}$ en $87 \pm 10,9 \mathrm{~mm} \mathrm{Hg}$.

Bij de vrouwelijke deelnemers uit de QI categorie I bedraagt de gemiddelde systolische bloeddruk $117 \pm 12,2 \mathrm{~mm} \mathrm{Hg}$, uit de categorie III, $139 \pm 19,3 \mathrm{~mm} \mathrm{Hg}$. De diastolische waarden bedragen respectievelijk $74 \pm 9,0 \mathrm{~mm} \mathrm{Hg}$ en $86 \pm 11,2 \mathrm{~mm} \mathrm{Hg}$. Zowel bij de mannelijke als bij de vrouwelijke deelnemers wordt een hogere systolische. en diastolische bloeddruk waargenomen bij een $Q I \geqslant 28$ in vergelijking met een $Q I \leqslant 22$ (tabel 21).

Onder ernstig overgewicht wordt een QI van $\geqslant 28$ of 30 verstaan $39,169,170$. Beziet men nu de groep mannen en vrouwen met een $Q 1 \geqslant 28$, dan blijken daar 9 mannen en 44 vrouwen een $Q I \geqslant 30$ te hebben.

Gemiddeld bedraagt de QI van deze personen respectievelijk $31,8 \pm 1,4$ $(n=9)$ en $32,7 \pm 3,0(n=44)$. Bij deze personen is eveneens gekeken naar de hoogte van de natrium- en kaliumuitscheiding in de 24-uurs urine, de molaire natrium $/ \mathrm{kalium}$ ratio alsmede de bloeddrukwaarden. Bij de mannelijke deelnemers is de gemiddelde natriumuitscheiding $207 \pm 57,2$ mmol, de kaliumuitscheiding $92 \pm 22,2 \mathrm{mmol}$ en de molaire natrium $/ \mathrm{ka}-$ lium ratio $2,4 \pm 0,81$. De gemiddelde systolische bloeddruk bedraagt $150 \pm 17,2 \mathrm{~mm} \mathrm{Hg}$, de diastolische bloeddruk $91 \pm 8,5 \mathrm{~mm} \mathrm{Hg}$. De gevonden waarden bij de mannelijke deelnemers met een $Q \mathrm{P} \geqslant 30$ zijn dus meestal hoger dan de gemiddelde waarden bij de groep met een lagere QI. De natrium/kalium ratio is echter in beide gevallen gelijk.

Bij de vrouwelijke deelnemers is de gemiddelde natriumuitscheiding $155 \pm 61,8 \mathrm{mmol}$, de kaliumuitscheiding $69 \pm 21,2 \mathrm{mmol}$ en de molaire natrium/kalium ratio $2,4 \pm 1,05$. De gemiddelde systolische bloeddruk bedraagt $138 \pm 18,2 \mathrm{~mm} \mathrm{Hg}$, de diastolische bloeddruk $85 \pm 10,1 \mathrm{~mm} \mathrm{Hg}$. Behoudens de bloeddrukwaarden, laten de uitkomsten bij de vrouwelijke deelnemers met een $\mathrm{QI} \geqslant 30$, hogere waarden zien dan bij de lagere $\mathrm{QI}$ (tabel 21)

Deze bevindingen sluiten geheel aan bij hetgeen door Tanskanen beschreven is: ook deze auteur vond een toename van de natrium- en kaliumuitscheiding alsmede van de molaire natrium/kalium ratio bij een hoger wordende Quetelet-index ${ }^{78}$. Joossens et al bevestigen deze bevindingen slechts ten dele. $\mathrm{Zij}$ vonden onder mannelijke deelnemers een $z$ wak ${ }_{\text {s. }}$ onder vrouwelijke deelnemers geen verband tussen het lichaamsgewicht en de hoogte van de natriumuitscheiding ${ }^{81}$. Niet in de laatste 
plaats dient vermeld te worden, dat Ten Berge- $v$.d. Schaaf een duidelijke positieve relatie vond tussen de hoogte van de natrium- en kaliumuitscheiding en de Quetelet-index bij 10 to 13 jarige kinderen. Het verband met het lichaamsgewicht alleen is voor de jongens en meisjes "zo mogelijke nog sterker". Ook vond genoemde auteur een verband tussen de hoogte van de QI en de hoogte van de bloeddruk ${ }^{192}$.

Sanchez-Catillo et al vonden, dat mannen een hogere natriuminneming hadden dan vrouwen. Dit verschil bleef - in tegenstelling tot het Brielse onderzoek - ook na correctie voor het lichaamsgewicht bestaan ${ }^{87}$.

\subsection{De voedingsenquêtegegevens en de 24-uurs urinewaarden}

5.6.1. Vergelijking van de natrium-, kalium-, calcium- en magnesiumconsumptiegegevens met de urineanalyses

Van 876 personen ( 407 mannen en 469 vrouwen) zijn voedinsenquêtegegevens verkregen. (zie paragraaf 4.2.1.). Bij 4 mannen en 8 vrouwen zijn enkele waarden verloren gegaan. De resultaten van de consumptiegegevens van de 10 nagevraagde voedingsmiddelen zijn in de tabellen $h \mathrm{t} / \mathrm{m} \mathrm{q}$ weergegeven. De inter-individuele spreiding is aanzienlijk. Met behulp van de U.V.C.-tabel is een berekening gemaakt van de hoeveelheid natrium, kalium en calcium, die de opgegeven voedingsmiddelen gezamenlijk leveren ${ }^{216}$. Aan de hand van beschikbare, gestandaardiseerde analysegegevens is dezelfde berekening gemaakt van het gehalte aan magnesinum. Tabel 22 geeft een overzicht van de resultaten naar leeftijd en geslacht, omgerekend naar mmol per dag.

Het gemiddelde natriumgehalte in de gezamenlijke voedingsmiddelen waarvan de consumptie is nagevraagd, bedraagt bij de mannelijke deelnemers $96 \mathrm{mmol}$ en bij de vrouwelijke deelnemers $68 \mathrm{mmol}$ per dag. Bij de mannelijke deelnemers vertonen de 18-24 jarigen de hoogste, berekende natriuminneming, $114 \mathrm{mmol}$ en de personen van 70 jaar en ouder de laagste, $74 \mathrm{mmol}$ per dag. Ook onder de vrouwen zijn het de 18-24 jarigen die de hoogste natriumconsumptie hebben zoals die berekend kon worden via de voedingsenquête. Het betreft $77 \mathrm{mmol}$ per dag terwijl de 65-69 jarige vrouwen de laagste natriuminneming laten zien, $55 \mathrm{mmol}$ per dag. Zowel bij de mannen als de vrouwen kan men zien dat de natriuminneming via de nagevraagde voedingsmiddelen bij de jongere deelnemers hoger is dan bij de ouderen.

Het gemiddelde kaliumgehalte van de door de mannelijke deelnemers geconsumeerde voeding, berekend uit de enquête, bedraagt $92 \mathrm{mmol}$ per dag. Bij de vrouwen is dit iets lager, $75 \mathrm{mmol}$ per dag. De groep jongste mannelijke deelnemers, $18-24$ jaar, vertoont de hoogste kalliuminneming, $98 \mathrm{mmol}$ per dag. De 65-69 jarigen onder de mannelijke deeinemers de 
laagste, $83 \mathrm{mmol}$ per dag. Bij de vrouwen zijn het de $55-59$ jarigen met de hoogste en de 65-69 jaar oude deelneemsters met de laagste kaliuminneming, respectievelijk 82 en 72 mmol per dag. Zowel bij de mannen als bij de vrouwen ziet men dat de hoogte van de kaliuminneming via de nagevraagde voedingsmiddelen tussen de leeftijdscategorieën betrekkelijk constant is.

Het gemiddelde calciumgehalte van de geconsumeerde, nagevraagde voedingsmiddelen bedraagt bij de mannen 28 en bij de vrouwen $24 \mathrm{mmol}$ per dag. Onder de mannelijke deelnemers zijn het de 18-24 jarigen met het hoogste (34 mmol) en de 65-69 jarigen met het laagste calciumgebruik (24 mmol per dag). Bij de vrouwen zijn het eveneens de 18 -24 jarigen die de hoogste calciumwaarden melden $(28 \mathrm{mmol})$ en de 65-69 jarigen die de laagste uitkomsten opgeven (21 mmol per dag). Bij de mannelijke en vrouwelijke deelnemers is de hoogte van de calciuminneming met name vanaf het $25^{\mathrm{e}}$ levensjaar redelijk constant.

De gemiddelde magnesiumopneming uit de voedingsmiddelen, zoals die in de voedingsmiddelenenquête zijn nagevraagd, bedraagt bij de mannelijke deelnemers $10 \mathrm{mmol}$ en bij de vrouwen $8 \mathrm{mmol}$ per dag. Bij de mannelijke deelnemers laten de 18-24 jarigen de hoogste en de 65-69 jarigen de laagste magnesiuminneming zien: respectievelijk 11 en $9 \mathrm{mmol}$ per dag. Bij de vrowwen zijn het eveneens de 18-24 jarigen met de hoogste en de 65-69 jarigen met de laagste magenesiumwaarden: respectievelijk 9 en $8 \mathrm{mmol}$ per dag. Zowel onder de mannelijke als onder de vrouwelijke deelnemers is de hoogte van de magnesiuminneming voor de diverse leeftijdscategorieën redelijk constant.

Tabel 22 geeft naast de natrium-, kalium-, calcium- en magnesiumuitkomsten, berekend uit de voedingsenquête, tevens de electrolytenwaarden in de 24-uurs urine weer. Te berekenen valt dat het totale natriumgehalte opgrond van de voedingsenquête bij de mannen gemiddeld $58 \%$ en bijdevrouwelijke deelnemers gemiddeld $50 \%$ van de totale natriumuitscheiding in de 24-uurs urine verklaart. Dit percentage varieert overigens met de leeftijd. Zo bedraagt het bij de mannelijke deelnemers van $18-24$ jaar $68 \%$ en bij de $60-64$ jarigen $46 \%$. Bij de vrouwelijke deelnemers bedragen deze hoogste en laagste percentages respectievelijk 59 en 44 bij de leeftijdscategorieën 60-64 en $70+$ jaar.

Hoewel de kaliumuitscheiding in de 24-uurs urine als de belangrijkste weergave van de dagelijkse inneming kan worden gezien, blijken de waarden uit deze voedingsenquête toch nog hoger uit te vallen. Het verschil tussen de in de voedingsenquête verkregen kaliumwaarden en die uit de 24-uurs urine, geeft een indruk van de mate van "overwaardering" bij een voedingsanamnestisch onderzoek als het onderhavige. Het valt op, dat deze bij het totaal der mannen en vrouwen nagenoeg gelijk is, te weten respectievelijk 15 en $14 \%$. 
Indien de berekende hoeveelheden calcium de totale daginneming weerspiegelen, zal de urinaire calciumexcretie $10-35 \%$ van deze waarde te bedragen ${ }^{47}$. Te berekenen valt, dat de gemiddelde calciumuitscheiding in de 24 -uurs urine bij de mannen, $18 \%$ en bij de vrouwen $17 \%$ van de via de voedingsenquête verkregen gegevens bedraagt. Tussen de leeftijdscategorieën bestaat wel enig verschil. Zo varieert het percentage bij de mannen van 12 tot 20 en bij de vrouwelijke deelnemers van 13 tot 20 . De waargenomen uitscheiding valt dus in het verwachte traject.

Van de totaal opgenomen hoeveelheid magnesium zou ongeveer een derde deel via de nieren worden uitgescheiden ${ }^{62}$. Het blijkt echter, dat gemiddeld het magnesiumgehalte in de 24-uurs urine, de helft van de waarde, verkregen uit de voedingsenquête bedraagt. Bij de mannelijke deelnemers $49 \%$, bij de vrouwen $50 \%$. Evenals bij calcium, ziet men hier verschillen tussen de onderscheiden leeftijdsgroepen. Bij de mannelijke deelnemers varieert dit percentage van 43 tot 54 en bij de vrouwen van 42 tot 57 .

\subsubsection{Bijdrage van de onderscheiden voedingsmiddelen aan de natriumin- neming}

In afbeelding 23 is een overzicht gegeven van het gemiddelde natriumgehalte van de onderscheiden voedingsprodukten per 100 gram of $100 \mathrm{milli}$ liter ${ }^{261}$. Het blijkt, dat de vleeswaren gemiddeld een aanzienlijk hoger natriumgehalte $(1986 \mathrm{mg} / 100 \mathrm{~g})$ hebben dan bijwoorbeeld vlees en vis $(100 \mathrm{mg} / 100 \mathrm{~g})$. Brood en kaas zijn eveneens natriumrijk, respectievelijk 500 en $860 \mathrm{mg}$ per $100 \mathrm{~g}$. Eileren bevatten $150 \mathrm{mg}$ natrium per $100 \mathrm{~g}$, groenten (vers en bedrijfsmatig bewerkt gecombineerd) $74 \mathrm{mg}$, melk en melkprodukten $35 \mathrm{mg}$, fruit en aardappelen respectievelijk 4 en $2 \mathrm{mg}$. Opgemerkt zij, dat het in dit onderzoek gehanteerde natriumgehalte voor vleeswaren iets hoger ligt dan dat in het Voedingsraadrapport Vermindering gebruik keukenzout: $1130 \mathrm{mg} / 100 \mathrm{~g}^{52}$.

Tevens zijn in deze afbeelding de hoeveelheden kalium en de berekende molaire natrium/kalium ratio aangegeven. Duidelijk blijkt dat de voedingsprodukten brood, vleeswaren en kaas een hoge ratio hebben.

In tabel $r$ wordt een overzicht gegeven van de procentuele bijdrage welke de tien nagevraagde voedingsmiddelen leveren aan de totale (berekende) natriuminneming naar leeftijd en geslacht. Zoals te verwachten, waren brood, vleeswaren en kaas de belangrijkste natriumbronnen. Opvallend is, dat dit niet alleen opgaat voor de mannelijke en vrouwelijke deelnemers maar ook voor de onderscheiden leeftijdscategorieën. Tevens zijn de percentages per leeftijdsgroep en per voedingsmiddel redelijk constant. Hetgeen de betekenis van deze voedingsprodukten bij de natriuminneming onderstreept. Zo blijkt de broodconsumptie van de man- 
nelijke deelnemers gemiddeld voor $37 \%$ aan de berekende natriuminneming bij te dragen. Bij de vrouwelijke deelnemers bedraagt dit percentage 36. Van de 10 nagevraagde voedingsmiddelen draagt de vleeswarenconsumptie van de mannen voor $26 \%$ en wan de vrouwen voor $20 \%$ bij aan de natriuminneming. Voor het kaasgebruik bedragen deze percentages respectievelijk 13 en 16. De gezamenlijke bijdrage van de drie genoemde voedingsprodukten is bij de mannen 76 en bij de vrouwen $72 \%$. De procentuele bijdrage van de overige, minder natriumrijke produkten aan de totale, uit de 10 nagevraagde voedingsmiddelen berekende natriuminneming, is veel geringer. Hoewel deze woor de melk- en melkproduktenconsumptie bij de mannen 9 en bij de vrouwen $10 \%$ bedraagt. Bij de groentenconsumptie zijn deze percentages achtereenvolgens 8 en 10 . Afbeelding 24 beeldt een en ander uit.

Tenslotte is de relatie berekend tussen het natriumgethalte, verkregen uit de voedingsenquête en de hoogte van de natriumuitscheiding un de 24-uurs urine. Ditmaal uitgesplitst naar de bellangrijkste natriumbronnen: brood, vleeswaren, kaas, melk en melkprodukten alsmede hun gezamenlijke bijdrage.

Bij de mannelijke deelnemers varieert, afhankelijk van de leeftijd, de bijdrage van brood tussen de 17 en $25 \%$. Vleeswaren leveren 10 en $21 \%$, kaas $7-8 \%$ en melk en melkprodukten $4-6 \%$. Die gezamenlijke bijdrage van genoemde voedingsmiddelen aan de totale 24 -uurs natriumuitscheiding in de urine bedraagt gemiddeld $48 \%$.

Bij de vrouwelijke deelmemers is deze gezamenlijke bijdrage gemiddeld $40 \%$. Het natriumgehalte, berekend uit de broodconsumptie bedraagt afhankelijk van de leeftijd, 14 tot $21 \%$ van de totale urine-excretie. Voor de vleeswarenconsumptie is dit 7 tot $12 \%$, voor de kaasconsumptie 6 tot $10 \%$, terwijl het natriumgehalte van de geconsumeerde hoeveelheid melk en melkprodukten, 4 tot $6 \%$ aan de 24 -uurs natriumuitscheiding bijdraagt. Voor mannen en vrouwen gezamenlijk bedragen deze waarden gemiddeld: brood-19\%, vleeswaren- $13 \%$, kaas- $8 \%$ en melk en melkprodukten-5\%.

Met nadruk zij vermeld, dat het hier gaat om een vergelijking van de habituele natriuminneming berekend uit de gemiddelde consumptie van een aantal hoog-natriumhoudende voedingsmiddelen met de gemiddelde natriumuitscheiding in de 24-uurs urine. Het een en ander geeft dan ook niet meer dan een indicatie. $E r$ is derhalve geen individueel verband te verwachten tussen de berekende natriuminneming en de totale uitscheiding in de 24-uurs urine.

Het mag opmerkelijk worden genoemd, dat de gezamenlijke procentuele natriumbijdrage van de nagevraagde voedingsmiddelen brood, vleeswaren en kaas onder de mannen met de hoogste natriumuitschei- 
ding, $80 \%$ en onder de mannen met de laagste natriumuitscheiding $75 \%$ van de berekende inneming is. Dit komt overeen met respectievelijk 92 en $70 \mathrm{mmol}$ natrium. Bij de vrouwelijke deelnemers bedragen deze percentages respectievelijk 78 en 72 ofwel 58 en $49 \mathrm{mmol}$ natrium. Tussen de onderscheiden voedingsmiddelen vindt enige verschuiving plaats. Zo draagt de vleeswarenconsumptie onder de groep mannen met de hoogste natriumuitscheiding voor $40 \%$ bij aan de totale, berekende natriuminneming. Bij de mannen met de laagste natriumurinewaarden, voor 32\%. De brood- en kaasconsumptiebijdragen blijven in beide gevallen nagenoeg gelijk, respectievelijk $32 \%$ versus $33 \%$ en $8 \%$ versus $10 \%$. De procentuele bijdrage van de vleeswarenconsumptie aan de berekende natriuminneming is bij de vrouwelijke deelnemers met de hoogste natriumuitscheiding eveneens hoger dan bij de vrouwen met de laagste urinewaarde, $26 \%$ versus $19 \%$. De bijdrage via de broodconsumptie is bij de eerstgenoemde groep vrouwen evenwel iets lager dan bij de laatstgenoemde categorie, $33 \%$ versus $36 \%$. De bijdrage van de kaasconsumptie is iets hoger, $19 \%$ versus $17 \%$.

Concluderend kan worden gesteld dat alleen al de gangbare voedingsmiddelen brood, vleeswaren en kaas bij de mannen met gemiddeld 73 mmol en bij de vrouwen met $49 \mathrm{mmol}$ aan de dagelijkse natriuminneming bijdragen. Tevens blijkt, dat personen met de hoogste natriumuitscheidingswaarden in de 24-uurs urine een grotere consumptie van deze voedingsmiddelen laten zien, dan degenen met de laagste excretie-uitkomsten.

Tenslotte kan met de in dit onderzoek gehanteerde korte voedingsenquête bij de mannen $58 \%$ van de natriumuitscheiding en bij de vrouwelijke deelnemers gemiddeld $50 \%$ van de in de urine aangetroffen hoeveelheden worden verklaard. De praktische relevantie van het bovenstaande is, dat een groot deel van de dagelijkse natriuminneming afkomstig is uit "alledaagse" voedingsmiddelen. Beinvloeding van de zoutconsumptie zal derhalve geen eenvoudige opgave zijn. Op deze problematiek wordt in de hoofdstukken 6 en 7 nader ingegaan.

\subsection{De tweede urineverameling - intra-individuele variabiliteit}

Van de 140 personen ( 70 mannen en 70 wrouwen), die zijn benaderd met de vraag of zij bereid waren voor een tweede maal de 24-uurs urine te verzamelen, bleken 55 mannen en 57 vrouwen in de gelegenheid hieraan te voldoen. Uiteindelijk leverden van hen 108 personen ( 52 mannen en 56 vrouwen) bruikbare 24-uurs urine in. Dit is $12 \%$ van het total aantal deelnemers. 


\subsubsection{Natrium}

Voor de natriumwaarden geldt dat het verschil tussen de eerste en de tweede waarneming zowel bij de mannelijke als de vrouwelijke deelnemers significant is. De correlatiecoëfficiënt $r$, tussen de eerste en tweede meting is berekend. Voor de mannelijke deelnemers bedraagt deze 0,278, woor de vrouwelijke deelnemers 0,285. Afbeelding 25 toont het spreidingsdiagram van de eerste en tweede natriumuitscheidingswaarden voor beide geslachten.

In tabel 23 is naar categorie van de natriumuitscheiding $(<100,100-$ $149,150-199,200-249 \mathrm{en} \geqslant 250 \mathrm{mmol}$ ) het percentage mannen en vrouwen weergegeven dat binnen de onderscheiden klasse walt. Bij de mannen blijken zowel bij de eerste als bij de tweede urineverzameling de meesten in de klasse van 100-149 mmol natrium per 24 uur te vallen, respectievelijk 35 en $39 \%$. Een algemene verschuiving van een hogere klasse naar een lagere blijkt uit het feit, dat bij de tweede urinemeting twee maal zoweel mannen een natriumuitscheiding van $<100$ mmol per 24 uur hebben dan bij de eerste bepaling - van 14 naar $29 \%$. Tevens heeft geen van de deelnemers meer een uitscheiding van $\geqslant 250 \mathrm{mmol}$; bij de eerste urinemeting bedroeg dit percentage nog 10 .

Onder de vrouwelijke deelnemers is het percentage met een natriumuitscheiding $<100 \mathrm{mmol}$ per 24 uur zelfs drie maal groter dan bij de tweede urinemeting in vergelijking tot de eerste - van 14 naar $43 \%$. Geen van de deelneemsters laat een uitscheiding zien van $\geqslant 200 \mathrm{mmol}$ terwijl dit bij de eerste meting nog $14 \%$ bedroeg.

Bij nadere uitwerking blijkt, dat $27 \%$ van de mannelijke deelnemers en $32 \%$ van de vrouwen in dezelfde klasse blijven, terwijl $58 \%$ van de mannen en $54 \%$ van de vrouwen bij de tweede urineverzameling natriumuitscheidingswaarden laten zien, die één of meer klassen lager uitvallen. Daarentegen laat de tweede 24-uurs urine bij $15 \%$ van de mannen en $14 \%$ van de vrouwen een natriumwaarde zien, die één of meer klassen hoger ligt. Tabel 24 geeft hiervan een overzicht.

De gemiddelde waarde van de natriumuitscheiding bedraagt voor alle deelnemers 151 mmol. De standarddeviatie binnen personen is 48,81 mmol. De variatiecoefficiënt is derhalve $32,3 \%$. Wul men de standaardafwijking wan het gemiddelde terugbrengen naat ongeveer $10 \%$ van die gemiddelde natriumuitscheiding (15,1 mmol) dan is het aantal noodzakelijke waarnemingen aan één persoon ongeveer 11 .

\subsubsection{Kalium}

Voor de kaliumwaarden geldt dat het verschil tussen de eerste en tweede warneming zowel bij de mannelijke als bij de vrouwelijke deelnemers eveneens significant is. 
Ook voor kalium is de correlatiecoëffieciënt $r$ tussen de eerste en tweede urinemeting berekend. Bij de mannelijke deelnemers bedraagt deze 0,258. Bij de vrouwelijke deelnemers 0,057. Afbeelding 26 toont het spreidingsdiagram voor beide geslachten.

In tabel 23 is naar categorie van de kaliumuitscheiding $(<40,40-59$, $60-79,80-99$ en $\geqslant 100 \mathrm{mmol}$ ) het percentage mannen en vrouwen weergegeven, dat binnen de onderscheiden klasse valt. Komt bij de eerste urinemeting 33\% van de mannelijke deelnemers in de klasse $80-99 \mathrm{mmol}$ kalium terecht, bij de tweede meting valt het hoogste percentage in de klasse 40-59 mmol, 42\%. Het percentage mannen met een kaliumuitscheiding van $<40 \mathrm{mmol}$ stijgt van $2 \%$ in de eerste meting naar $12 \%$ in de tweede.

Ook onder de vrouwelijke deelnemers valt een verschuiving van hogere naar lagere klassen waar te nemen. Heeft in de eerste meting nog $18 \%$ een kaliumuitscheiding van $\geqslant 80 \mathrm{mmol}$, in de tweede meting is dit slechts $5 \%$. Het percentage vrouwen met een kaliumuitscheiding van $<40 \mathrm{mmol}$ stijgt van $13 \%$ in de eerste naar $16 \%$ in de tweede meting.

Bij nadere uitwerking blijkt, dat $15 \%$ van de mannelijke deelnemers en $20 \%$ van de vrouwen in dezelfde klasse blijven terwijl $67 \%$ van de mannen en $63 \%$ van de vrouwen bij de tweede urineverzameling een kaliumuitscheiding laten zien, die één of meer klassen lager uitvalt. Daarentegen laat de tweede 24 -uurs urine bij $17 \%$ van de mannen en $18 \%$ van de vrouwen een kaliumuitscheiding zien, die één of meer klassen hoger ligt. Tabel 24 geeft hiervan een overzicht.

De gemiddelde waarde van de kaliumuitscheiding voor alle deelnemers bedraagt $72 \mathrm{mmol}$. De standaarddeviatie binnen personen is $14,32 \mathrm{mmol}$. De variatiecoëfficiënt is derhalve $19,9 \%$. Wil men de standaardafwijking van het gemiddelde terugbrengen naar ongeveer $10 \%$ van die gemiddelde kaliumuitscheiding $(7,2 \mathrm{mmol})$ dan is het aantal noodzakelijke waarnemingen aan één persoon ongeveer 4 .

\subsubsection{Calcium en magnesium}

De gemiddelde waarde van de calciumuitscheiding voor alle deelnemers bedraagt 4,6 mmol. Destandaarddeviatie binnen personen is $1,23 \mathrm{mmol}$. De variatiecoëfficiënt is derhalve $26,8 \%$. Wil mende standaardafwijking van het gemiddelde terugbrengen naar ongeveer $10 \%$ van die gemiddelde calciumuitscheiding $(0,46 \mathrm{mmol})$ dan is het aantal noodzakelijke waarnemingen aan éến persoon ongeveer 7 . De gemiddelde waarde van de magnesiumuitscheiding over alle deelnemers bedraagt $4,4 \mathrm{mmol}$. De standaarddeviatie binnen personen is $0,99 \mathrm{mmol}$. De variatiecoëfficiënt is derhalve $22,5 \%$. Wil men de standaardafwijking van het gemiddelde terugbrengen naar ongeveer $10 \%$ van die gemiddelde magnesiumuit- 
scheiding $(0,44$ mmol) dan is het aantal noodzakelijke waarnemingen aan één persoon ongeveer 5 . Op de betekenis van deze uitkomsten wordt in hoof dstuk 6 nader ingegaan.

\subsubsection{Nadere analyse van de natrium-en kaliumresultaten}

Zoals verwacht, verschillen de individuele waarden van de eerste en tweede urinemeting voor zowel de natrium- als de kaliumuitscheiding significant. Ook uit dit onderzoek blijkt een sterke intra-individuele variabiliteit met variatiecoëfficiënten van respectievelijk 32 en $20 \%$. Allereerst dient te worden vermeld, dat zelfs onder, wat de voeding betreft, strikt constante en gecontroleerde omstandigheden enige spreiding in de excretiewaarden blijft bestaan ${ }^{90}$. Daarenboven zal met name een wisselend voedingspatroon met verschillende hoeveelheden natrium en kalium van dag tot dag belangrijk hicraan bijdragen. Het is opmerkelijk dat de gemiddelde natrium- en kaliumuitscheidingswaarden de tweede maal significant lager uitvielen dan tijdens de eerste onderzoeksperiode. Verstorende factoren kunnen het groepsresultaat beïnloed hebben.

Zo bestaat de mogelijkheid, dat de proefpersonen de tweede keer de urine onzorgvildiger hebben verzameld dan de eerste maal. Teneinde inzicht te verkrijgen in de betrou wbaarheid van de tweede urineverzameling zijn dezelfde criteria gehanteerd als tijdens de eerste ronde. Bovendien is nagegaan of de creatinineuitscheidingswaarden van de tweede urinemeting verschillen van de eerste. Noch bij de mannelijke, noch bij de vrouwelijke deelnemers blijkt er evenwel een significant verschil. De intra-individuele variatiecoëfficiënt bedraagt voor creatinine $14,8 \%$. Liu et al stellen, dat de meeste studies een variatiecoëfficiënt van $<25 \%$ laten zien. Een waarde $>40 \%$ wordt door hen beschouwd als een teken dat er incompleet is verzameld ${ }^{86}$. In hoofdstuk 6 zal hierop nader worden ingegaan. De correlatiecoëfficiënt $r$ tussen de eerste en tweede creatinineuitscheiding bedraagt bij de mannelijke deelnemers $0,373(0,001<P<0,01)$. Bij de vrouwelijke deelnemers bedraagt deze $0,459(\mathrm{P}<0,001)$. Het aanta noodzakelijke waarnemingen aan eén persoon om de standaardafwijking van de gemiddelde creatinineuitscheidingswaarden binnen $10 \%$ van dat gemiddelde te brengen, is berekend op 2. Op grond van het voorafgaande, kan worden gesteld, dat de eerste en tweede urineverzameling redelijk analoog is geschied.

Ook kan het een en ander het gevolg zijn van bekendheid met het doel van het onderzoek zodat de deelnemers bewust de hoogte van de natriumconsumptie verlaagden. Hiertegen pleit echter het feit, dat het kaliumgehalte in de dagelijkse voeding moeilijk is te beïnvloeden; deze was de tweede keer eveneens lager.

Tenslotte bestaat de mogelijkheid, dat het eerder beschreven verzameldag- 
effect de resultaten wan de eerste en tweede urine-uitkomsten verstoort. Het aantal deelnemers is evenwel te gering om een opslitsing naar leeftijd, geslacht en urineverzame॥dag zinvol te kunnen maken. Wel blijkt dat bij de mannelijke deelnemers die de eerste en de tweede urine in dezelfde periode van de week verzamelden, de gevonden gemiddelde natriumwaarden niet meer van elkaar verschillen. Bij de vrouwelijke deelnemers blijkt het significante verschil te verdwijnen indien men uitsluitend personen, die beide keren in het weekend verzamelden met elkaar vergelijkt. Constant houden van de verzamelperiode (weekdagen, weekend) lijkt te resulteren in een afname van de intra-individuele variabiliteit. Ook is een invloed van de verzameldag op de kaliumwaarden in dit verband zowel bij de mannelijke als bij de vrouwelijke deelnemers enigszins aanwezig. Geconcludeerd moet worden dat een verzameldageffect mede debet is aan het verschil tussen de beide gemiddelde urine-uitkomsten.

Gezien het eerder gevonden verband tussen de hoogte van de Queteletindex en de hoogte van de natrium- en kaliumuitscheiding in de 24-uurs urine, zijn de deelnemers van de eerste en tweede urineverzameling ingedeeld naar een QI-categorie van: $Q I \leqslant 22,22<\mathrm{QI}<25,25 \leqslant \mathrm{QI}<28$ en $\mathrm{QI} \geqslant 28$. Gekeken is bij welke QI-categorie het verschil tussen de gepaarde waarnemingen significant wordt dan wel verdwijnt. Bij de mannelijke deelnemers blijkt dit verschil voor zowel natrium als kalium met name bij degenen met een $25 \leqslant \mathrm{QI}<28$ significant. De correlatiecoëfficiënt $r$ bedraagt bij degenen met een $Q I \geqslant 25 \quad(n=25)$ voor natrium 0,410 $(0,01<\mathrm{P}<0,02)$ en voor kalium $0,323(\mathrm{P}>0,1)$. Het mag opmerkelijk worden genoemd dat deze waarden respectievelijk $0,929(\mathrm{P}<0,001)$ en $0,705(P>0,1)$ bedragen indien men personen met een $Q I \geqslant 28(n=5)$ onderscheidt. Het een en ander duidt aan, dat hoewel het slechts om een klein aantal deelnemers gaat, de intra-individuele variabiliteit bij adipeuse mannen geringer is dan bij degenen met een lagere QI. Bij de vrouwelijke deelnemers zijn het degenen met een $22<Q \mathrm{Q}<25$, waarbij de hoogte van de eerste natriumuitscheiding significant van die van de tweede verschilt. Voor de kaliumwaarden treedt dit verschil bij de deelnemers met een $25 \leqslant \mathrm{QI}<28$ op. Bij de overige categorieën verdwijnen de significante verschillen grotendeels. De correlatiecoëfficiënt $r$ bedraagt bij de groep vrouwelijke deelnemers met een $22<\mathrm{QI}<28 \quad(\mathrm{n}=27)$ voor natrium $0,478(0,01<\mathrm{P}<0,02)$ en voor kalium $0,301(\mathrm{P}>0,1)$. Bij de vrouwen met een $Q 1 \geqslant 28(n=18)$ wordt voor zowel natrium als kalium een negatieve correlatie gevonden, respectievelijk $-0,200 \quad(P>0,1)$ en $-0,558$ $(0,01<\mathrm{P}<0,02)$. Ook bij de vrouwelijke deelnemers met een $\mathrm{Q} \geqslant 28$ lijkt de binnenpersoonsvariantie voor natrium en kalium geringer dan bij de minder adipeusen. Aangenomen is dat de Quetellet-index in de periode liggend tussen de eerste en tweede verzameling niet is veranderd. Tevens 
is, gezien de kleine aantallen geen correctie woor de verzameldag toegepast.

Tenslotte is nog gekeken naar de hoogte van de molaire natrium/kalium ratio's, berekend uit de urine-uitscheidingswaarden van de eerste en tweede meting. Noch bij de mannelijke noch bij de vrouwelijke deelnemers is het verschil tussen deze gepaarde waarnemingen significant $(\mathrm{P}>0,1)$. De variatiecoëfficiênt bedraagt $7,7 \%$.

De correlatiecoëfficiënt $r$ bedraagt voor de mannelijke deelnemers $0,123(\mathrm{P}>0,1)$, bij de vrouwen $0,555(\mathrm{P}<0,001)$. Gezien de geringe correlatie bij de mannelijke deelnemers is tevens gecorrigeerd voor de eerder genoemde QI-categorieën. Mannen met een $\mathrm{QI}<25(\mathrm{n}=27)$ laten een correlatiecoëfficiënt van $0,297(P>0,1)$ zien. Bij een $Q P \geqslant 25(n=25)$ bedraagt deze $0,471(0,001<\mathrm{P}<0,01)$. Onderscheidt men degenen met een $\mathrm{Q} I \geqslant 28$ dan bedraagt deze zelfs $0,965(0,001<\mathrm{P}<0,01)$.

Wellicht speelt een abnormale verdeling van de gevonden waarden eveneens een rol bij de zwakke correlatie onder de mannelijke deelnemers. Derhalve is tevens de rang-correlatiecoëfficiënt (Spearman) berekend ${ }^{245}$. Deze bedraagt 0,997 - bij de vrouwelijke deelnemers: 0.998 .

Concluderend kan men stellen, dat de intra-individuele variabiliteit van de molaire natrium/kalium ratio veel geringer is dan die van natrium en kalium afzonderlijk. Op het praktische belang hiervan wordt in de hoofdstukken 6 en 7 nader ingegaan. 


\section{BESCHOUWING VAN DE URINEBEPALINGEN EN DE VOEDINGSENQUETE}

De waarde van de uitkomsten van het urineonderzoek hangt volledig af van de nauwkeurigheid waarmee de urine is verzameld. Een betrouwbare methode ter bepaling van de volledigheid van de 24-uurs urineverzameling is niet beschikbaar ${ }^{86,89,155,262}$. De betrouwbaarheid van de hiervoor dikwijls aanbevolen en toegepaste creatinine-uitscheiding is in dezen onvoldoende vanwege de sterke inter-en intra-individuele variabiliteit. Niet alleen blijkt deze parameter afhankelijk van leeftijd en geslacht doch eveneens van de gebruikte voeding en de lichaamsbeweging ${ }^{76,85,88}$. $90,186,262$. Uitgevoerde variantie-analyse resulteerde dan ook in een percentage verklaarde variantie van 8 door leeftijd, 28 door het geslacht en 1 door de urineverzameldag. Wat betreft de binnenpersoonsvariatie stellen Liu et al, dat deze meestal onder de $25 \%$ valt. Een variatiecoëfficiënt boven $40 \%$ zou volgens deze auteurs pas als een teken van incomplete urineverzameling mogen worden gezien. Hoewel meer onderzoek hiernaar wordt aanbevolen ${ }^{86}$. Webster et al stellen echter dat creatininewaarden geen goede indicator in dezen vormen. In onderzoek onder adipeuse vrouwen nemen zij een intra-individuele variatiecoëfficiënt van $8,7-34,4 \%$ waar $^{89}$. Van Dokkum komt tot een soortgelijke bevindingen met een intra-individuele variatiecoëfficiênt van 5-27\%. Zelfs onder strikt gecontroleerde omstandigheden bij een constante voeding blijkt deze nog $5-8 \%^{90}$. Dit is dus waarschijnlijk een soort fysiologisch minimum voor de intra-individuele variatie in de creatinine-uitscheiding.

Ook Kesteloot stelt dat de 24-uurs creatinine-excretie hoewel dikwijls aanbevolen toch van beperkte waarde is na invoering van deze uitkomsten als onafhankelijke variabele in multipele regressie-analyse ${ }^{155}$. Dit laatste wordt door de WHO bepleit ${ }^{262}$.

Samenvattend is de hoogte van de creatinine-uitscheiding in de 24-uurs urine geen voldoende betrouwbare maat voor het vaststellen van de compleetheid van de urineverzameling. Gezien het aantal verstorende variabelen ook niet wanneer deze wordt uitgedrukt per kilogram lichaamsgewicht.

Recent is door de WHO de mogelijkheid geopperd, para-aminobenzoëzuur als indicator voor de compleetheid van de 24-uurs urine te gebruiken $^{262}$. In paragraaf 2.2 .1 , is hierop gewezen. Onlangs gepubliceerd onderzoek waarbij $240 \mathrm{mg}$ van deze stof (in 3 capsules, verdeeld over de 
urineverzameldag) werd ingenomen liet in $17 \%$ van de gevallen een incomplete urineverzameling zien ${ }^{91}$. Slechts $14 \%$ van deze gevallen zou volgens de auteurs via het gebruik van creatinine als parameter en $29 \%$ via eigen melding gevonden zijn. Deze methode lijkt dan ook een belangrijke bijdrage te kunnen geven aan de oplossing van de problematiek rond de urineverzameling. Het is evenwel de vraag of - met name in grootschalig populatie-onderzoek - het verzoek capsules in te nemen, niet tot de introductie wan een nieuwe foutenbron aanleiding zal geven. Het is nog onduidelijk of proefpersonen in een dergelijke studie-opzet hiertoe bereid zijn en of de capsules daadwerkelijk alle drie worden ingenomen. Daar komt nog bij dat het gebruik van vitamine-B preparaten en paracetamolhoudende geneesmiddelen vermeden moeten worden in verband met hun, op para-aminobenzoëzuur gelijkende, chemische structuur $^{\text {i1 }}$. De schrijvers stellen dat het niet ontdekken van verkeerd verzamelde 24- uurs urine aanleiding geeft tot een systematische onderwaardering van de werkelijke hoogte van de natrium- en kaliumuitscheiding.

Terzijde zij opgemerkt dat de exacte volledigheid van de 24-uurs urine, inzake de bepaling van de molaire natrium/kalium ratio van minder stringent belang is. In paragraaf 7.1.2. wordt op de praktische betekenis hiervan nader ingegaan.

Teneinde in het onderhavige onderzoek toch verzekerd te zijn van betrouwbare, goed verzamelde 24-uurs urines, is dan ook in sterke mate vertrouwd op de goede relatie van de huisarts en zijn assistente met de onderzoekspopulatie. Allereerst is een zeer uitwoerige mondelinge en schriftelijke uitleg over de wijze van verzamelen gegeven. Achteraf is navraag gedaan naar eventuele problemen tijdens het verzamelen en zijn de genoteerde verzameltijden gecontroleerd ${ }^{262}$. Indien onnauwkeurigheden bleken, is de betrokkene gevraagd de urineverzameling nog een keer te herhalen. Tanskanen sloot, alleen afgaande op anamnestische gegevens inzake de verzameling, $7,7 \%$ van de deelnemers uit. Op basis van gemeten creatininewaarden behoefde door hem niemand te worden uitgesloten ${ }^{78}$.

Tenslotte is aan de hand van de tweede urineverzameling een grove controle op de eerste 24-uurs urine uitgevoerd. Het blijkt dat de binnenpersoonsvariatie voor creatinine ruim binnen de door Liu et al gestelde $40 \%$ blijft, namelijk 14,8\%. Er zijn dus 2 verzamelingen nodig teneinde de betrokkene naar creatinine-uitscheiding te kunnen karakteriseren. Deze waarde komt overeen met de variantiecoëfficiënt, die door Van Dokkum is gevonden in balansstudies ${ }^{90}$. Het verschil tussen de eerste en tweede creatinine-uitscheiding blijkt niet significant. Hierwit mag worden geconcludeerd, dat de verzamelingen redelijk analoog zijn geschied.

Volgens de algemeen geldende criteria is aldus getracht de urineverza- 
meling zo nauwkeurig mogelijk te laten verlopen.

Gemiddeld ligt de hoogte van de natriumuitscheiding in de 24-uurs urine boven de aanvaardbaar geachte hoeveelheid. De kaliumuitscheiding ligt daar echter onder. Beiden blijken afhankelijk van de leeftijd, het geslacht en de dag waarop de urine is verzameld. In eerste instantie zijn de gevonden waarden reeds naar leeftijd en geslacht getabelleerd. De invloed van deze twee factoren, hoewel significant, blijkt slechts een zeer gering deel van de variantie in de waarnemingen te kunnen ver"klaren, schommelend tussen 1 en $9 \%$. De onafhankelijke variabele: dag van urineverzameling, verklaart een nog kleiner percentage van de variantie - 1 à $2 \%$. De verklaring voor dit gevonden verzameldageffect moet voor een deel worden gezocht in een wisselend consumptiepatroon. Zo is bekend, dat er met name een verschil in energieopname bestaat tussen het voedingspatroon gedurende het weekend en op de door de weekse dagen. Baecke et al stellen overigens dat deze, althans bij jonge mannen, met name aan de duidelijk hogere alcoholconsumptie moet worden toegeschreven $^{240}$. Voorts kan men zich voorstellen, dat het gebruik van etenswaren tussen de maaltijden door - waarvan bekend is, dat deze een belangrijke bijdrage kunnen leveren aan de dagelijkse energetische opname - in het weekend frequenter geschiedt ${ }^{240,241}$. De slechts zwak significante invloed en het uiterst lage percentage verklaarde variantie, minimaliseren de praktische betekenis van de dag waarop de urime wordt verzameld. Hoewel de van dag-tot-dag variatie wel een deel van de waargenomen binnenpersoonsvariabiliteit verklaart. Tevens blijft het in dit verband de vraag, hoe snel en hoe lang de invloed van een "afwijkend" consumptiepatroon zich in de 24-uurs urine weerspiegelt. De schattingen lopen uiteen van drie tot zes dagen ${ }^{87,262}$. De voor leeftijd en geslacht gecorrigeerde natriumexcretiewaarden op de verzameldagen zondag en maandag, vallen bij de mannelijke deelnemers over het algemeen hoger uit dan op de overige dagen. Dit verschil is evenwel niet significant. Onder de vrouwelijke deelnemers wordt zo'n verschil niet waargenomen. Joossens et al zien geen significante verschillen in de hoogte van de electrolytenuitscheiding gedurende de werkdagen en het weekend ${ }^{81}$. Liu et al vinden daarentegen juist een 5-10\% lagere natriumuitscheiding in het weekend ${ }^{85}$. Gelet op het voorafgaande dient te worden geadviseerd, in grootschalig populatieonderzoek de urineverzameldag naar vrije keus te laten. Daar komt nog bij, dat voor personen die buiten de deur of in continudienst werken, de urineverzameling op een voorgeschreven dag moeilijk kan zijn. Herhaalde metingen dienen zoveel mogelijk op overeenkomstige dagen van de week te worden uitgevoerd.

Concluderend wordt gesteld dat andere dan de hier gehanteerde variabelen van invloed zijn op de hoogte van de natrium- en kaliumuit- 
scheiding in de 24-uurs urine. Zelfs personen die opgaven een natriumbeperkt dieet te volgen, hebben geen significant lagere natriumuitscheiding in de 24-uurs urine dan de overige deelnemers. Deze bevinding wordt door het onderzoek van Daenen et al onder mannelijke bejaarden bevestigd $^{230}$. Een en ander werpt een somber licht op de effectiviteit van dieetvoorschriften.

De sterke intra-individuele variabiliteit in de natrium- en kaliumuitscheiding in de 24-uurs urine, bemoeilijkt het vaststellen van de habituele inneming. Niettemin zou men voor het instellen op een dieet dan wel voor het aantonen van de relatie tussen zoutgebruik en bloeddruk, wel inzicht willen hebben in dit habituele zoutgebruik. Voor het vaststellen van de individuele natriuminneming binnen nauwe grenzen zijn echter zoals uit dit onderzoek is gebleken circa elf 24-uurs urineverzamelingen vereist; voor kalium vier. De gevonden waarden voor de intra-individuele variabiliteit sluiten goed aan bij de gegevens uit de literatuur ${ }^{81,85,262}$. Overigens toonde Van Dokkum aan, dat zelfs onder sterk gecontroleerde omstandigheden, bij een constante natriuminneming gedurende 60 dagen, de variatiecoëfficiënt nog altijd $\pm 15 \%$ bedraagt ${ }^{90}$. De molaire natrium/creatinine ratio veranderde hieraan nauwelijks iets, hetgeen door Liu et al wordt bevestigd ${ }^{86,90}$. Van verdere verwerking van de natrium/creatinine en kalium/creatinine ratio is dan ook afgezien. Hoewel het opmerkelijk is, dat de eerstgenoemde waarde nagenoeg onafhankelijk is van de leeftijd en geslacht.

Er blijkt een samenhang te bestaan tussen het lichaamsgewicht en de natrium- en kaliumuitscheiding in de 24-uurs urine. De natrium- en kaliumwaarden per kilogram lichaamsgewicht zijn voor het merendeel van de participanten constant. Dit geldt overigens niet voor het verband tussen waarden van Quetelet-index en de natrium-en kaliumuitscheiding in de 24-uurs urine. Het voorafgaande geeft steun aan de veronderstelling dat obesen een grotere voedselconsumptie hebben dan personen met een lager lichaamsgewicht ervan uitgaande dat het natriumgehalte van de dagelijkse voeding per energie-eenheid betrekkelijk constant is $31,52,169$. Aan de hand van de tweede urinemeting is bovendien berekend, dat de intra-individuele variabiliteit in natrium- en kaliumuitscheiding bij degenen met een $Q I \geqslant 28$ geringer is dan bij personen met een lagere $\mathrm{QI}$. Hetgeen betekent dat deze groep personen met overgewicht niet alleen een relatief hoge natriumuitscheiding laat zien doch eveneens dat deze stabiel is.

De uit de 24-uurs urine berekende molaire natrium/kalium ratio is bij de deelnemers aan het onderzoek nagenoeg onafhankelijk van de leeftijd en het geslacht. $82 \%$ van de deelnemers heeft een ratio van $\geqslant 2$ en $32 \%$ $\geqslant 3$. 
Het verschil tussen de twee gepaarde waarnemingen - wan de eerste en de tweede urineverzameling - is niet significant. Dit, gevoegd bij de geringe intra-individuele variantiecoëfficiènt voor deze ratio betekent dat een éénmalige 24-uurs urine voldoende is om iemand qua molaire natrium/kalium ratio te karakteriseren. De praktische relevantie van deze bevinding is, dat de molaire natrium/kalium ratio van de totale dagelijkse voeding redelijk constant is.

Voorts is het belangwekkend te zien, dat met het hoger worden van de molaire natrium/kalium ratio de bijdrage van natrium aan de hoogte van het quotiënt toeneemt, terwijl die van kalium kleiner wordt. In hoofdstuk 7 wordt op de praktische betekenis van de natrium/kalium-verhouding ingegaan.

Evenals in het geval van natrium en kalium zijn het alleen de onafhankelijke variabelen leeftijd, geslacht en urineverzameling, die een weliswaar significant doch geringe invloed uitoefenen op de variantie in de calciumuitscheiding. Bij de magnesiumuitscheiding ontbreekt het urineverzameldageffect echter. De overige ingevoerde onalhankelijke variabelen blijken van niet-significant belang. De praktische betekenis van de waarde van de calcium- en magnesiumuitscheiding in de 24-uurs urine wordt echter in hoge mate beperkt door het feit, dat deze slechts een zeer gedeeltelijke afspiegeling van de dagelijkse inneming zijn - respectievelijk $10-35 \%$ en ongeveer $33 \% 47,62,92,93$. Daar komt nog bij, dat uit de intra-individuele variabiliteit blijkt, dat voor calcium zeven en voor magnesium vijf 24-uurs urineverzamelingen noodzakelijk zullen zijn will men een schatting kunnen maken, die ongeveer binnen $10 \%$ van de werkelijke gemiddelde waarde ligt. Een en ander betekent, dat deze beide urineparameters slechts een zeer betrekkelijke waarde hebben in epidemiologisch onderzoek.

De gegevens uit de voedingsenquête tonen, zoals te verwachten was, geen direct verband met de natrium- en kaliumuitscheiding in de 24-uurs urine. Niet alleen de beperkte hoeveelheid nagevraagde voedingsmiddelen en de gebruikte standaardmaten en consumptiefrequentie en de berekeningswijze zijn hier debet aan. Ook is de gevonden intra-individuele variabiliteit in de natrium- en kaliumuitscheiding in de 24-uurs urine van belang. Wel lijken de voedingsmiddelen brood, vleeswaren en kaas een belangrijke en constante bijdrage te leveren aan de dagelijkse natriuminneming. Hetgeen geheel aansluit bij de gegevens van de Voedingsraad hoewel de hier gevonden uitkomsten enigszins hoger liggen ${ }^{52}$. De Voedingsraad schat dat (omgerekend en niet voor leeftijd en geslacht gecorrigeerd) circa $12 \%$ van de totale natriuminneming afkomstig is uit de geconsumeerde hoeveelheid brood, $6 \%$ uit vleeswaren en $5 \%$ uit kaas. In de onderhavige studie bedragen deze percentages respectievelijk: 19, 13 
en 8. De aanzienlijke spreiding in de voedselconsumptie en her verschil in wijze van bepalen zijn mede de oorzaak van dit verschil. De gevonden gemiddelde natriumwaarde komt bij de mannelijke deelnemers goed overeen met het natriumgehalte berekend op grond van een hypothetisch opgesteld huidig Nederlands voedingspatroon van $2700 \mathrm{Kcal}$ (11MJ) per dag. Omgerekend bedroeg het natriumgehalte in dit voorbeeld 101 $\mathrm{mmol}^{254}$. In de Brielse studie $96 \mathrm{mmol}$ bij de mannen en $68 \mathrm{mmol}$ bij de vrouwen. Opgemerkt zij, dat het in het eerste geval om de totale daghoeveelheid gaat overigens zonder de bij de huishoudelijke bewerking toegevoegde hoeveelheid zout. De berekende natriuminneming is dan ook aan de lage kant. Het onderzoek onderstreept de keuze van de nagevraagde voedingsmiddelen in de Brielse studie. De praktische relevantie van de natriumuitkomsten van de voedingsenquête is dat, aangezien zeer gangbare voedingsmiddelen verantwoordelijk zijn voor een groot deel van de totale natriuminneming, interventie uitermate moeilijk zal zijn. Temeer als de veronderstelling juist is, dat de natriumdichtheid van de voeding (per energie-eenheid) redelijk constant is. Ondeskundige vermindering van de natriuminneming kan aldus tot tekorten van met name calcium en magnesium leiden ${ }^{61}$.

De berekende kaliumwaarden tonen een gunstig innameniveau. Wel zijn de gevonden waarden aanzienlijk lager dan de berekende uitkomsten uit de Zutphen Studie. Kromhout et al beschrijven een onderzoek onder mannen van 40-59 jaar met een kaliuminneming van (omgerekend) \pm 130 $\mathrm{mmol} / \mathrm{dag}$ in 1960 . In 1965 bedroeg deze $\pm 110 \mathrm{mmol}$ en in $1970 \pm 102$

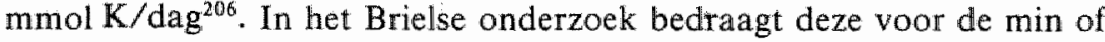
meer vergelijkbare leeftijdsklasse, $94 \mathrm{mmol}$. Ander onderzoek van genoemde auteur laat zien, dat bif een hypothetisch voedingspatroon, 91 mmol $\mathrm{K}$ wordt ingenomen ${ }^{254}$. De Brielse gegevens sluiten hierop aan: mannen $92 \mathrm{mmol}$, vrouwen $75 \mathrm{mmol}$. Hoewel de kaliumuitscheiding in de 24-uurs urine als belangrijkste weergave van deze dagelijkse inneming moet worden gezien, blijken de waarden uit de voedingsenquête toch nog hoger uit te vallen. Deze discrepantie kan mogelijk worden toegeschreven aan kaliumverliezen tijdens de bedrijfsmatige en huishoudelijke bewerking, alsmede aan de sterke variatie in het kaliumgehalte van deze produkten ${ }^{52,263}$. Deze factoren beperken de waarde van voedingsanamnestisch onderzoek inzake kalium enigszins.

Het is opmerkelijk dat de drie genoemde, gangbare voedingsmiddelen brood, veeswaten en kaas tesamen voor een buitengewoon ongunstige molaire natrium/kalium ratio zorg dragen: bij de mannen 6,6 en bij de vrouwen 7,0. Door de andere - meer kaliumhoudende - nagevraagde voedingsmiddelen wordt dit overigens weer grotendeels gecompenseerd. De totale berekende, gemiddelde ratio bedraagt bij de mannen 1,0 en bij 
de vrouwen 0,9 . In hoofdstuk 7 zal hierop nader worden ingegaan.

De gegevens uit de verkorte voedingsenquête laten zien, dat de aanbevolen hoeveellheid van $800 \mathrm{mg}$ calcium per dag $(20 \mathrm{mmol})$, althans door de hier onderscheiden groepen, rumschoots wordt gehaald ${ }^{62,90}$. De gevonden calciumuitscheidingswaarden staan in redelijk constante verhouding tot de berekende inneming en vallen binnen de genoemde 10$35 \%$. De fysiologische spreiding in de uitscheiding via de urine is, zoals gesteld, evenwel te groot om de 24-uurs waarde als maat voor de calciuminneming te hanteren. Anamnestische gegevens lijken daartoe beter geschikt. De gevonden calciumwaarden komen overeen met het eerder beschreven Zutphen onderzoek ${ }^{206}$. Uitgaande van genoemd hypothetisch voedingspatroon, berekende Kromhout dat dagelijks $26 \mathrm{mmol}$ calcium zou worden geconsumeerd ${ }^{254}$. In de onderhavige studie bedraagt dit bij mannen 28 en vrouwen $24 \mathrm{mmol}$.

De aanbevolen hoeveelheid van 200-400 mg magnesium per dag (8-17 mmol) wordt daarentegen krap bereikt $\mathrm{t}^{47,62}$. Doorgaans bevat de gangbare voeding in de westerse wereld echter voldoende magnesium om de behoefte te dekken ${ }^{47,62}$. Het ligt dan ook voor de hand te veronderstellen, dat de berekende magnesiuminneming is "ondergewaardeerd", zulks enerzijds tengevolge van het deels ontbreken van gegevens over de magnesiumgehalten in voedingsmiddelen ${ }^{261}$. Anderzijds heeft een onderschatting plaatsgevonden, doordat magnesium aanwezig is in een grote verscheidenheid aan voedingsmiddelen die niet alle in de voedingsenquête waren opgenomen. Het blijkt dientengevolge dat het percentage magnesium, dat via de urine wordt uitgescheiden hoger ligt dan de op de fysiologische gronden bepaalde $33 \%$. Een eenvoudige en betrouwbare methode ter bepaling van de dagelijkse magnesiuminneming is derhalve niet beschikbaar.

Concluderend wordt gesteld, dat de hier gehanteerde voedingsenquête bruikbaar is om de relatieve bijdrage van een aantal hoog-natriumhoudende voedingsmiddelen aan de dagelijkse natriuminneming vast te stellen. Ook voor het bepalen van de dagelijkse kaliuminneming is deze enquête geschikt hoewel met enige overwaardering rekening moet worden gehouden. Voor het vaststellen van de calciuminneming lijkt de enquête uiterst bruikbaar, voor magnesium in het geheel niet. 


\section{PRAKTISCHE CONSEQUENTIES: PRIMAIRE EN SECUNDAIRE PREVENTIE VAN HYPERTENSIE}

\subsection{Maatregelen op individueel niveau}

\section{1. 1. Primaire preventie bij risicodragers}

De vraag of "leefregels" bij personen met een familiair belaste anamnese voor hypertensie preventief werken op het zich ontwikkelen van hoge bloeddruk, is onbeantwoord. Toch is het verdedigbaar deze risicodragers - in het kader wan de aambevolen voorlichting over een "verstandige leefwijze" - te wijzen op de noodzaak de hoogte van de natriuminneming tot $100 \mathrm{mmol}$ per dag te beperken en te adviseren een Quetelet-index tussen 20 en $25 \mathrm{~kg} / \mathrm{m}^{2}$ te handhaven ${ }^{39,254}$. Voorwaarde is wel dat zij op de hoogte zijn van het feit dat zij extra risico lopen op grond van hun familiaire belasting ${ }^{264}$. De huisarts heeft in dezen een belangrijke voorlichtende taak.

Het gaat hierbij om een groot aantal personen. Zo heeft $19 \%$ van de deelnemers aan dit onderzoek een familiair belaste anamnese voor harten vaatziekten en $23 \%$ voor hypertensie. Opsporing van deze risicodragers binnen de huisartspraktijk is een moeilijke opgave; een goed registratiesysteem is een vereiste. Een actieve benadering van alle patiënten draagt ertoe bij, dat in 3 jaar $90 \%$ van de relevante gegevens beschikbaar kan zijn ${ }^{43}$.

In de onderhavige studie blijken degenen met zo'n belaste anamnese zich quat electrolytenuitscheiding niet van de overige deeinemers te onderscheiden, hetgeen de noodzaak van voedingsmaatregelen onderstreept. Ter vermindering van de natriuminneming is het vermijden van het gebruik van keukenzout en van sterk natriumhoudende produkten in eerste instantie aangewezen ${ }^{265}$.

In veel gevallen zullen deze maatregelen evenwel onvoldoende zijn. Alleen al gezien hiet gevonden belang van de alledaagse voedingsmiddelen bij de natriuminneming kan het noodzakelijk zijn de individuele situatie door de diètist te laten beoordelen zulks mede in relatie tot het lichaamsgewicht en de - in dit onderzoek daarmee samenhangende - hoogte van de natriumuitscheiding. 


\subsubsection{Secundaire preventie bij hypertensiepatiënten}

Over het nut wan vermindering van het keukenzoutgebruik door mensen met essentiële hypertensie bestaat overeenstemming; over de mate waarin dit moet gebeuren daarentegen niet $1,8,18,31,32,149,266$. Ter discussie staat de vraag of personen met hypertensie de dagelijkse natriuminneming tot circa $35 \mathrm{mmol}$ moeten laten dalen of dat een lichtere beperking - tot $\pm 70 \mathrm{mmol}$ - reeds een therapeutisch effect heeft $104_{t} 149,267$. In geen van beide gevallen is beperking een eenvoudige opgave. Daarnaast zal reductie van overgewicht tot een Quetelet-index kleiner dan 28 of zelfs 25 , eveneens een vaak moeilijk te realiseren maatregel zijn ${ }^{18,39,254,268,269,270}$.

Uit het hier beschreven onderzoek blijkt enerzijds dat een hoog percentage deelnemers - verdeeld over de gehele onderzoekspopulatie - ver boven de genoemde natrium-en Quetelet-indexwaarden uitkomt. Anderzijds heeft $22,5 \%$ een bloeddruk (bij eerste meting) die, gemeten naar de criteria van de Gezondheidsraad voor behandeling in aanmerking komt. Ook uit de literatuur blijkt, dat de grootte van deze groep niet onderschat moet worden ${ }^{8}$. Zo is berekend dat - in Nederland - bij 1.630.000 personen van 35-65 jaar een diastolische waarde van $\geqslant 90 \mathrm{~mm} \mathrm{Hg}$ kan worden verwacht, hetgeen bij 5500 huisartspraktijken op ongeveer 300 personen per praktijk zou neerkomen. Dit aantal komt na herhaalde bloeddrukmeting naar alle waarschijnlijkheid echter lager te liggen ${ }^{8,38,256}$ " Bij deze becijfering is evenwel nog geen rekening gehouden met het feit, dat de helft van de Nederlandse bejaarden een verhoogde bloeddruk heeft ${ }^{8}$. Recent gepubliceerd onderzoek ondersteunt het gunstige effect op morbiditeit en mortaliteit van behandeling van hypertensie bij bejaar$\operatorname{den}^{271,272}$.

Aldus blijkt dat per huisartspraktijk een respectabel aantal personen vóórkomt dat volgens de algemeen geldende opvattingen in het kader van de secundaire (en zoals uit paragraaf 7.1.1. bleek ook primaire) preventie van hypertensie in aanmerking komt voor dieetinterventie. De Gezondheidsraad stelt hierover: "Aangezien het opvolgen van dergelijke adviezen in de overgrote meerderheid der gevallen een drastische wijziging van diepgewortelde voedingsgewoonten zal inhouden, is intensieve coöperatie en een langdurige follow-up noodzakelijk"1. Bij deze longitudinale benadering van het hypertensievraagstuk is - gelet op de hier gevonden

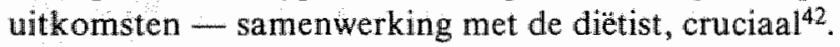

Wil men het resultaat van deze interventie echter in de tijd enigszins nauwkeurig volgen, dan dient - zoals uiteengezet - de 24-uurs urine vele malen te worden verzameld. Gesteld, dat een maandelijkse controle op de effectiviteit van het voedingspatroon gewenst is, dan betekent dit bij elf verzamelingen per meetpunt - idealiter 132 maal 24-uurs urineverzamelingen per individu per jaar. Aangenomen dat, door het dalende 
gemiddelde, de absolute spreiding van de natriumwaarden afneemt, zou er een grotere standaardafwijking van het gemiddelde (hoger dan de hier steeds gehanteerde $10 \%$ ) kunnen worden geaccepteerd: bijwoorbeeld $20 \%$. In dat geval zijn drie metingen per meetpunt per individu noodzakelijk en voldoende, hetgeen een aanzienlijke vereenvoudiging van de procedure betekent. Desalniettemin is het evident, dat de voorkeur moet worden gegeven aan het bepalen van de hoogte van de molaire natrium/ kalium ratio. Niet alleen vanwege de relevantie van deze grootheid in de bloeddrukregulatie, maar met name ook op grond van praktische overwegingen, namelijk de in dit onderzoek gevonden, geringere intraindividuele variabiliteit van deze parameter. Voorts is het in dit geval waarschijnlijk minder noodzakelijk dat de urine over exact 24 uur verzameld wordt ${ }^{86,91}$. Een bijkomend argument wordt ontleend aan de waarneming in dit onderzoek dat een hogere $\mathrm{Na} / \mathrm{K}$ ratio vooral werd veroorzaakt door een sterk verhoogde natriumexcretie.

Aangenomen dat aanvankelijk een maandelijkse controle op de voedselinneming noodzakelijk is, betekent dit 12 urineverzamelingen per individu per jaar. Wellicht kan op langere termijn gelijke tred worden gehouden met de bloeddrukcontrole, zodat slechts 3 à 4 maal per jaar de 24-uurs urine op de hoogte van de molaire natrium/kalium ratio behoeft te worden onderzocht.

Verwerking van de verzamelde urines tot monsters welke naar het laboratorium kunnen worden gestuurd, is, zoals uit het onderzoek blijkt, binnen de huisartspraktijk mogelijk. Overigens is extra praktijkassistentie in dat geval een vereiste. Huisartsen dienen met praktijkassistenten, de plaatselijke diëtisten, het Voorlichtingsbureau voor de Voeding, de betrokken laboratoria en niet in de laatste plaats de ziektekostenverzekeraars tot sluitende afspraken te komen over de wijze waarop het een en ander organisatorisch en financieel moet worden geregeld. Op de noodzaak van verandering van de organisatie van de huisartspraktijk bij het uitwoeren van preventieve taken is reeds meermalen gewezen 1,8,27,43.

De Wereldgezondheidsorganisatie en de Gezondheidsraad pleiten voor het reduceren van het lichaamsgewicht en de dagelijkse zoutconsumptie door hypertensiepatiènten. Indien men de dagelijkse natriuminneming effectief wil laten dalen, zal dit - gelet op de onderzoeksresultaten gemiddeld zeker met $50 \%$ dienen te gebeuren. Gezien de gecompliceerdheid op woedingskundig gebied en de moeilijkheid de compliance ten aanzien van de voedingsvoorschriften te controleren, dient de geschetste weg te worden bewandeld. Centraal staat evenwel de vraag of het verantwoord is de betrokken patiënten aan zo'n "therapeutisch regime" bloot te stellen ${ }^{273}$. Niet in de laatste plaats omdat - hoewel de bereidheid een natriumbeperkte voeding te gebruiken is aangetoond - zal blijken dat 
individuele interventie gedoemd is te mislukken als een ondersteunend voedingsbeleid wan de overheid achterwege blijft $13,274,275,276,277,278$. Dit wordt dan ook dringend aanbevolen en vormt een absolute voorwaarde voor het welslagen van de aan de huisarts opgedragen taak.

\subsection{Maatregelen op populatie-niveau}

Alles bijeen blijkt een aanzienlijk deel van de bevolking, naar algemeen aanvaarde inzichten, voor energie- en natrumbeperkende maatregelen in aanmerking te komen. Het is zeer de vraag of overheidsmaatregelen, alleen al gezien het aantal personen in kwestie, achterwege kunnen blijven.

In algemene zin geldt dat alleen maatregelen in de primair preventieve sfeer niet het neveneffect van medicalisering met zich meebrengen ${ }^{279}$. Of reductie van het zoutgebruik door de gehele bevolking tot een daling van het gemiddelde bloeddrukpeil en aldus tot een verlaging van de met hypertensie samenhangende morbiditeit en mortaliteit leidt, is evenwel niet aangetoond ${ }^{1,8}$. Niet jedereen bepleit dan ook voedingsmaatregelen op het niveau van de totale bevolking ${ }^{31}{ }^{154}$. Toch wordt gesteld, dat bij een zeer drastische verlaging van de dagelijkse natriuminneming tot rond $35 \mathrm{mmol}$, het vóórkomen van hypertensie nagenoeg zal verdwijnen ${ }^{104}$. Zelfs wint het inzicht terrein, dat het gebruik van een dagelijkse voeding met een natriumgehalte van niet meer dan $100 \mathrm{mmol}$, de incidentie van hoge bloeddruk zal laten dallen $18,33,36,37,40,280$. Zoals in paragraaf 1.2 . is uiteengezet, kan een geringe daling wan een risicofactor die frequent in de populatie vóórkomt (zoutgebruik) verstrekkende gevolgen voor de incidentie van de ziekte hebben ${ }^{13}$. Met name is het dan ook van belang te weten of er groepen zijn te onderscheiden met een dusdanig extreem hoog zoutgebruik dat uitstel van interventiemaatregelen onverantwoord is. In het onderhavige onderzoeksmateriaal zijn inderdaad individuen aanwezig met een natriuminneming boven de genoemde grenshoeveelheid van $100 \mathrm{mmol}$. Het is echter niet mogelijk gebleken - met de hier gehanteerde onafhankelijke variabelen - deze op grond van andere gemeenschappelijke kenmerken te identificeren. Voor kalium geldt hetzelfde, met dien verstande dat het in dit geval erom gaat groepen te onderscheiden met een laag gebruik. De sterke binnenpersoonsvariatie in natrium- en kaliumuitscheiding rechtvaardigt een interventie op grond van de éénmalige waarneming bij de aangetroffen personen met extreme waarden echter niet.

De Wereldgezondheidsorganisatie gaat nog verder en adviseert de bevolking van de geindustrialiseerde landen, de natriuminneming tot zelfs 50 à $85 \mathrm{mmol}$ per dag te laten dalen ${ }^{18}$. De in dit onderzoek gevonden gemiddelde natriumwaarde, is weliswaar niet extreem hoog, maar toch 
zullen, indien men zich op het standpunt stelt dat een verlaging met $43 \%$ tot $85 \mathrm{mmol}$ of zelfs een verlaging met $66 \%$ tot $50 \mathrm{mmol}$ gewenst is, verstrekkende overheidsmaatregelen noodzakelijk zijn. De aanbevolen hoeveelheid wordt immers al geheel door de enkele, nagevraagde basis voedingsmiddelen bereikt.

De Voedingsraad stelt evenwell dat: "zonder consequenties ten aanzien van acceptatie, houdbaarheid en technologie een gemiddelde daling van de keukenzoutinneming door de volwassen bevolking met total ongeveer $20 \%$ is te bereiken". Hetgeen neerkomt op een daling van $34 \mathrm{mmol}$ natrium tot $103-120 \mathrm{mmol}$ per dag ${ }^{52}$. Het standpunt van de Gezondheidsraad pas nadere stappen op bevolkingsmiveau aan te bevelen, nadat meer duidelijkheid is verkregen omtrent de aard wan het verband tussen zoutconsumptie en bloeddrukhoogte, is enerzijds begrijpelijk anderzijds heeft zij, op grond van het voorafgaande reeds een voorlichtende taak. Deze beperkt zich niet tot het laten vermelden van het natriumgehalte op de verpakking van (bedrijfsmatig) bewerkte voedingsmiddelen $n^{1,39,52}$. Het verdient evenzeer aanbeveling de produktie van zoutbeperkte voedingsmiddelen te stimuleren en deze goedkoop en veelvuldig naast de thans gangbare etenswaren op de markt te brengen ${ }^{13,260,276,277,278,281}$. Op deze wijze kan de bevolking zelf een keuze maken en groeit de kennis wan zoutrijke produkten ${ }^{52}$. De Gezondheidsraad stelt immers: "Aan mensen die hun eigen verantwoordelijkheid ten opzichte van preventie willen dragen, moet hiertoe de gelegenheid woren geboden"1.

\subsection{Invoeging in algemeen aanvaard voedingsbeleid: de betekenis van de} molaire natrium/kalium ratio

De geschiedenis leert dat de mens in de loop der tijd niet alleen steeds meer natrium maar tevens minder kalium is gaan gebruiken. In paragraaf 2.1. is daar reeds op gewezen. Uit het onderzoek blijkt dat een thogere natrium/kalium ratio doorgans het resultaat is van zowel een hogere natrium- als een lagere kaliumuitscheiding. De smaak van ons voedingspatroon lijkt dan ook niet alleen door het hoge natrium doch eveneens door het lage kalium bepaald. De logische consequentie is dat beinvloeding van het natriumgehalte van de voeding niet los kan worden gezien van dat van kalium. Naar substitutie van kalium voor natrium is weinig onderzoek verricht; studies inzake de smaak zijn veelal alleen op natrium gericht ${ }^{52,204,282}$. Skrabal et al namen waar, dat de acceptatie van een natriumbeperkte voeding toenam na toevoeging van kalium ${ }^{212}$. Pietinen et al beschreven dat speciall vervaardigd (relatief kaliumrijk) zout, goed werd geaccepteerd 277,283 . Belangwekkend is het onderzoek van Mickelsen et al, die aantoonden dat de meeste proefpersonen geen verschil bemerkten 
tussen normaal keukenzout en een zoutmengsel met een molaire natrium/kalium ratio van 1,3 . Ook hiermee bereide produkten als brood en boter konden niet worden onderscheiden van het reguliere produkt ${ }^{141}$. De Voedingsraad stelt eveneens dat een gedeeltelijke vervanging van natrium door kalium in gangbare voedingsmiddelen qua smaak goed wordt geaccepteerd, doch beveelt meer onderzoek hiernaar aan ${ }^{52}$.

Gezien het (patho)fysiologische en epidemiologische belang van de molaire natrium/kalium ratio in relatie tot de bloeddrukregulatie alsmede de technologische noodzaak van een hoog electrolytengehalte in een aantal produkten is het dan ook de vraag of het aandachtsveld niet meer hierheen moet worden verlegd ${ }^{284}$. Niet in de laatste plaats vanwege de in dit onderzoek gevonden resultaten: bij het owergrote deel van de onderzoekspopulatie ( $99 \%$ ) blijkt deze ratio - zelfs bij herhaling ongunstig tot zeer ongunstig, onafhankelijk van het geslacht en nagenoeg onafhankelijk van de leeftijd, de urineverzameldag en de Quetelet-index. Het zijn met name de bedrijfsmatig bewerkte voedingsmiddelen als brood, vleeswaren en kaas waarvan de gezamenlijke consumptie een hoge molaire natrium/kalium ratio ( 6 à 7 ) bewerkstelligt. De overige nagevraagde voedingsprodukten hebben doorgaans een veel natuurlijker ratio van (ver) beneden de 1 en deze compenseren de extreme waarden weer tot circa 1. Onder invloed van de niet nagevraagde etenswaren en het gebruikte zout aan tafel komt deze ratio echter uit op een stabiel,ongunstig daggemiddelde van rüm 2.

Over de aard van genoemde voedingsmiddelen en/of toevoegingen draagt dit onderzoek geen informatie aan. Het is evenwel reëel te veronderstellen dat deze mede bestaat uit "tussendoortjes", snacks waarvan bekend is dat zij een niet te onderschatten "psycho-sociale" en "sensorische" functie vervulien ${ }^{254}$. Veelal betreft het sterk natriumhoudende, kaliumarme produkten op basis van vlees of kaas danwel soep, gebak, koekjes, frisdranken en versnaperingen als zoutjes $241,261,285,286$. De Voedingsraad spreekt in dit verband van "Jiefhebber" consumptie ${ }^{51,52}$. De huishoudlijke toevoeging van smaakbevorderende stoffen tijdens de maaltijdbereiding en -consumering zal evenmin een bijdrage leveren aan een evenwichtiger verdeling tussen natrium en kalium in de te consumeren voeding ${ }^{285}$. Naast keukenzout zijin alle aroma's, kruidenmengsels en strooisels doorgaans natriumzouten ${ }^{52}$.

Resumerend is het beter te stellen dat de bevolking is geconditioneerd op de smaak van een voeding met een hoge natrium/ $\mathrm{kalium}$ ratio dan met een hoog zoutgehalte, niet alleen uit patho-fysiologisch, doch tevens uit voedingsvoor lichtings en technologisch oogpunt bezien. Het propageren van een voeding met een meer gunstige natrium $/ \mathrm{kalium}$ verhouding past bij de thans - meer in algemene zin - heersende denkbeelden over een "gezonde voeding". Zo 
zal verschuiving van een voedingspatroon met hoofdzakelijk dierlijke bestanddelen naar een meer plantaardige samenstelling, een gunstig effect op de natrium/kalium ratio hebben. Ook andere, algemeen aanbevolen veranderingen in het voedingspatroon zullen niet alleen rechtstreeks een gunstige inwloed hebben op de bloeddrukregulatie maar tevens indirect bijdragen aan het realiseren van een lagere natrium/kalium ratio van de totale dagvoeding. In het bijzonder kunnen genoemd worden een verhoging van de $\mathrm{P} / \mathrm{S}$ ratio(meervoudig onverzadigd vet/verzadigd vet) van de voeding en een matiging van de dagelijkse alcoholconsumptie $25,39,176,178$, Een ruimer gebruik van aardappelen, graanprodukten, peulvruchten, groente, fruit, dieetmargarines, spijsoliën, noten en vis kan de samenstelling van de dagelijkse voeding in bovenstaande zin ombuigen. Een dergelijk voedingspatroon wordt in het algemeen, zelfs bij een voldoende broodgebruik, gekenmerkt door een natrium/kalium ratio van $<1^{254,287}$.

Cramwinckel noemt het zoveel mogelijk benadrukken van positieve aspecten van de voeding een essentiele voorwaarde voor het welslagen van voedingsvoorlichting 288 . Met andere woorden: het is kansrijker de consumptie van produkten met een gunstige natrium/kalium verhouding te stimuleren dan zout en zoutrijke produkten te verbieden. Daar komt nog bij dat de smaakpreferentie wordt beïnvloed indien aan het nieuw aanbevolen voedingspatroon een duidelijke gezondheidsboodschap wordt verbonden 60 . Overigens moeten voorlichters niet schromen de bevolking te wijzen op de buitengewoon onfysiologische natrium $/ \mathrm{kalium}$ ratio van vele, zeer alledaagse voedingsmiddelen.

Concluderend kan men stellen dat, indien de gegevens uit het Brielse onderzoek als een afspiegeling van de landelijke situatie mogen worden beschouwd en indien het belang van een hoge natrium/kalium ratio bij het ontstaan van hypertensie wordt onderschreven, een interventie ter werbetering van deze situatie zich op de gehele bevolking zal moeten richten. Primair preventieve maatregelen moeten in dat geval tot doel hebben, de natrium/kalium ratio van de voeding van de bevolking naar meer fysiologische warden terug te brengen.

Zo"n voedingsbeleid sluit aan bij de gangbare opvatting over een gezondere woeding in het algemeen: een verschuiving van een in hoofdzaak dierlijke voeding naar een meer plantaardige, met minder verzadigd vet en geraffineerde koolhydraten ${ }^{39,260,287,289,290}$. In engere zin moet het uitgangspunt zijn deze fundamentele onjuistheid uit ons voedingspatroon te elimineren door in eerste instantie te bewerkstelligen dat ook na bedrijfsmatige bewerking van voedingsmiddelen, de natuurlijke natrium/ kalium ratio van dle uitgangsprodukten goeddeels gehandhaafd blijft ${ }^{263}$. Daarnaast is vermelding van de molaire natrium/kalium ratio op de verpakking van alle voedingsmiddelen aangewezen, teneinde een bewust- 
wordingsproces in gang te zetten. Het volstaan met de natrium- en kaliumgehalten per 100 gram, - zoals wordt woorgesteld door de WHO $^{291}$ - is niet alleen weinig inzichtelijk, doch tevens misleidend, aangezien het in fysiologische zin om de molaire samenstelling gaat. De molaire ratio is een factor 1,7 groter dan de gewichtsverhouding.

De "medische wereld" moet zich "oriënteren omtrent de betekenis van voeding voor volksgezondheidsvraagstukken" aldus Hautvast en Hermus, 197963. De symptoomloze bedreiging die hypertensie voor de gezondheid vormt, zal evenwel weinigen motiveren tot het geven van moeilijk op te volgen voedingsiadviezen. Terecht onderstrepen de auteurs het belang van een "voedsel- en voedingsbeleid" in Nederland.

Oog hebben voor de onevenwichtige verhouding tussen de hoeveelheden natrium en kalium in de dagelijkse voeding, is van essentiele betekenis voor de primaire en secundaire preventie van hypertensie en dient aldus de aanzet tot zo'n voorwaardescheppend beleid te vormen. Niet in de laatste plaats omdat het smaakzintuig ons in de steek laat. 


\section{SAMENVATTING}

De dagelijkse natriuminneming van volkeren, levend in de geindustrialiseerde wereld, stijgt ver boven de fysiologische behoefte uit. Het kaliumgebruik is daarentegen betrekkelijk laag. Natrium en kalium lijken in nauwe samenhang met calcium en naar alle waarschijnlijkheid magnesium van essentiële betekenis voor de bloeddrukregulatie. Verstoring van de cellulaire wisselmechanismen van genoemde ionen resulteert in een vernauwing van de arteriolen. De aldus ontstane vergroting van de perifere valweerstand treedt ais bloeddrukverhogende factor op.

Lang niet alle epidemiologische studies onderschrijven - tengevolge van de sterke intra-individuele variatie van zowel bloeddruk als zoutuitscheiding en de invloed van verstorende variabelen - de zout-bloeddrukhypothese. Toch lijkt er overeenstemming te bestaan over de wenselijkheid, de dagelijkse keukenzoutconsumptie niet boven de 5 à 6 gram te laten stijgen. De hoogte van de dagelijkse natrium- en kaliuminneming door de bevolking is onvoldoende nauwkeurig bekend. Kennis hieromtrent is van belang om een schatting te kunnen maken van het risico dat het zoutgebruik voor de bevolking vormt.

Aangezien lichte hypertensie een omvangrijk gezondheidsprobleem is, dat op niet-farmacologische wijze bestreden dient te worden, is het van belang georiënteerd te zijn over de hoogte van dè twee risicofactoren in dezen, te weten overgewicht en overmatig keukenzoutgebruik. De huisarts is als eerstverantwoordelijke in de hypertensiebestrijding aangewezen. Hij dient dan ook inzicht te verkrijgen in het vóórkomen van genoemde risicofactoren in zijn praktijk.

In Brielle is in 1981 een beschrijvend, explorerend onderzoek opgezet. Doel van het onderzoek was onder de volwassen bevolking gegevens te verzamelen betreffende de hoogte van de bloeddruk en van het zoutgebruik en mogelijke factoren, die daarop van invloed zouden kunnen zijn. Van circa $59 \%$ van de 1500 aangeschrevenen uit de aselect getrokken steekproef zijn verwerkbare gegevens verkregen, 411 mannen en 477 vrouwen. Naast naar persoonlijke gegevens als leeftijd en geslacht is navraag gedaan naar de sociaal-economische achtergrond, de eventuele aanwezigheid van een (familiaire) belaste anamnese voor hart- en vaatziekten en hypertensie alsmede medicijn- en dieetgebruik. Behalve de lichaamslengte, het -gewicht en de kniebreedte, zijn polsfrequentie en bloeddrukhoogte gemeten. Aangezien het natrium- en kaliumgehalte in 
de 24-uurs urine, op groepsniveau een afspiegeling vormt van de inneming van deze electrolyten door die groep, is aan de deelnemers gevraagd éénmaal de 24-uurs urine te verzamelen. Tevens is de hoogte van de calcium-, magnesium- en creatinineuitscheiding in de verzamelde urine bepaald. Aan de hand van een voedingsenquête is getracht inzicht te verkrijgen in de hoogte van de dagelijkse consumptie van een aantal gangbare voedingsmiddelen. Berekend is het gehalte aan natrium, kalium, calcium en magnesium van de nagevraagde, geconsumeerde voedingsmiddelen. Tenslotte is na afloop van het onderzoek van circa $12 \%$ van de deelnemers voor een tweede maal de 24-uurs urine verzameld. Vergelijking van de eerste en de tweede verzamelde urine verschaft inzicht in de intra-individuele variabiliteit van de onderzochte urine parameters.

De gemiddelde Quetelet-index van de mannelijke deelnemers verschilt niet significant van die bij de vrouwen, respectievelijk $25 \pm 3$ en $25 \pm 4$ $\mathrm{kg} / \mathrm{m}^{2}$. Bij $16 \%$ van de mannelijke en $22 \%$ van de vrouwelijke deelnemers wordt een $\mathrm{QI} \geqslant 28$ gevonden.

Het resultaat van de éénmalige bloeddrukmeting laat zien dat $10 \%$ van de deelnemers een bloeddruk heeft van $\geqslant 160 \mathrm{~mm} \mathrm{Hg}$ systolisch en/of $\geqslant 95 \mathrm{~mm} \mathrm{Hg}$ diastolisch.

De gemiddelde natriumuitscheiding in de 24-uurs urine varieert, afhankelijk van de leeftijd bij de mannelijke deelnemers van $124 \pm 46$ tot $185 \pm 90 \mathrm{mmol}$. Bij de vrouwelijke deelnemers variëren deze waarden van $108 \pm 54$ tot $145 \pm 64 \mathrm{mmol}$.

De gemiddelde kaliumuitscheiding in de 24-uurs urine varieert, afhankelijk van de leeftijd bij de mannelijke deelnemers van $65 \pm 19$ tot $96 \pm 27$ mmol. Bij de vrouwelijke deelnemers variëren deze waarden van $57 \pm 18$ tot $71 \pm 17 \mathrm{mmol}$.

De gemiddelde calciumuitscheiding in de 24-uurs urine varieert, afhankelijk van de leeftijd bij de mannelijke deelnemers van $3,3 \pm 2,1$ tot $5,5 \pm 2,3 \mathrm{mmol}$. Bij de vrouwelijke deelnemers varièren deze waarden van $3,0 \pm 1,9$ tot $4,5 \pm 2,4 \mathrm{mmol}$.

De gemiddelde magnesiumuitscheiding in de 24-uurs urine varieert, afhankelijk van de leeftijd bij de mannelijke deelnemers van $4,0 \pm 1,2$ tot $5,3 \pm 1,4 \mathrm{mmol}$. Bij de vrouwelijke deelnemers variéren deze waarden van $3,3 \pm 1,3$ tot $4,3 \pm 1,4 \mathrm{mmol}_{\text {. }}$

De gemiddelde creatinineuitscheiding in de 24-uurs urine varieert, afhankelijk van de leeftijd bij de mannelijke deelnemers van $11,5 \pm 2,5$ tot $16,6 \pm 4,2 \mathrm{mmol}$. Bij de vrouwelijke deelnemers variëren deze waarden van $9,0 \pm 2,9$ tot $12,2 \pm 2,5 \mathrm{mmol}$.

Een procentuele werdeling van de hoogte van de natriumuitscheiding laat zien, dat $87 \%$ van de mannelijke en $75 \%$ van de vrouwelijke deelnemers waarden van $\geqslant 100$ mmol bereiken. Terwijl $26 \%$ van de mannen en 
$13 \%$ van de wrouwen een natriumuitscheiding van $\geqslant 200 \mathrm{mmol}$ laten zien. Het zijn met name de personen uit de jongste leeftijdscategorieën, die een hoge natriumuitscheiding vertonen.

Een procentuele verdeling van de kaliumuitscheidingswaarden laat zien, dat $81 \%$ van de mannelijke en $95 \%$ van de vrouwelijke deelnemers een kaliumexcretie hebben $\leqslant 100 \mathrm{mmol}$ per 24 uur. De jongere deelnemers hebben een wat hogere kaliumuitscheiding dan de oudere.

De berekende natrium/kalium ratio vertoont tussen de mannelijke en wrouwelijke deelnemers geen significant verschil en is gemiddeld $2,2 \pm 0,9$. De leeftijdsinvloed blijkt van ondergeschikt praktisch belang. De procentuele verdeling van de molaire natrium/kalium ratio laat zien, dat $99 \%$ van de deelnemers een waarde bereikt $\geqslant 1,82 \% \geqslant 2$ en $32 \% \geqslant 3$. Terwijl $9 \%$ een natrium/kalium ratio heeft $\geqslant 4$. Overduidelijk blijkt, dat de hoge ratio's vooral zijn terug te voeren op de hogere natriumexcretie. Voor het kalium geldt het omgekeerde: een sterkere bijdrage bij de lage ratio"s.

Met behulp van inorthogonale variantieanalyse is de invloed nagegaan van de onafhankelijke variabelen, geslacht, leeftijd, urineverzameldag, welstandsklasse, burgerlijke staat, anamnese voor hart- en vaatziekten en hypertensie, gebruik van diuretica of andere antihypertensiva alsmede het volgen van een natriumbeperkt dieet op de hoogten van de in de 24-uurs urine gemeten parameters. Slechts leeftijd en geslacht en in beperkte mate de urineverzameldag blijken hierop een significante invloed te hebben. Het percentage total verklaarde variantie door de onafhankelijke variabelen is over het algemeen overigens gering. Wel is een sterke positieve samenhang gevonden tussen de hoogte van de Quetelet-index en de hoogte van de natrium- en kaliumuitscheiding in de 24-uurs urine en de bloeddruk alsmede, zij het in mindere mate, met de natrium/kalium ratio.

Hoe moeilijk het is, aan de hand van de 24-uurs urine de echte individuele natriuminneming te bepalen, wordt geillustreerd aan de hand van de berekende intra-individuele variabiliteit. Berekend is, dat zeker elf metingen aan één persoon moeten worden verricht wil men de standaardafwijking van het gemiddelde binnen $10 \%$ van de gemiddelde individuele waarde brengen. Voor kalium zijn in dit verband vier metingen gewenst. De binnenpersoonsvariatiecoëfficiënt voor de creatinineuitscheiding bedraagt $15 \%$. Derhalve zijn zeker twee metingen aan één persoon nodig om een betrouwbare uitspraak te kunnen doen over de individuele creatinineuitscheiding. Deze parameter is dan ook slechts van beperkte waarde bij de beoordeling van de betrouwbaarheid van de urineverzameling. 
De gemiddelde natrium- en kaliumuitscheidingen uit de tweede urinemeting zijn significant lager dan de uitkomsten van de eerste urine. Aangezien de urineverzameling voldoende betrouwbaar is geschied, lijkt een gewijzigd voedingspatroon hieraan ten grondslag te liggen.

De uit de 24-uurs urine berekende molaire natrium/kalium ratio blijkt als meest stabiele factor naar voren te komen. De uitkomsten van de eerste en tweede meting verschillen niet significant van elkaar en vertonen een hoge rangcorrelatie.

De verkorte voedingsenquête verschaft inzicht in de habituele, dagelijkse consumptie van tien gangbare voedingsmiddelen. Het gemiddelde natriumgehalte van de nagevraagde voeding varieert, afhankelijk van de leeftijd bij de mannelijke deelnemers van 74 tot $114 \mathrm{mmol}$ per dag. Bij de vrouwelijke deelnemers variëren deze waarden van 55 tot $77 \mathrm{mmol}$.

Het gemiddelde kaliumgehalte varieert, afhankelijk van de leeftijd bij de mannelijke deelnemers van 83 tot $98 \mathrm{mmol}$ per dag. Bij de vrouwelijke deelnemers variëren deze waarden van 72 tot $82 \mathrm{mmol}$.

Het gemiddelde calciumgehalte varieert, afhankelijk van de leeftijd bij de mannelijke deelnemers van 24 tot $34 \mathrm{mmol}$ per dag. Bij de vrouwelijke deelnemers variëren deze waarden van 21 tot $28 \mathrm{mmol}$.

Het gemiddelde magnesiumgehalte varieert, afhankelijk van de leeftijd bij de mannelijke deelnemers van 9 tot $11 \mathrm{mmol}$ per dag. Bij de vrouwelijke deelnemers variëren deze waarden van 8 tot $9 \mathrm{mmol}$.

Nadere beschouwing van de bijdrage van de onderscheiden voedingsmiddelen aan de natriuminneming leert, dat vooral brood, vleeswaren en kaas van belang zijn. Hun gezamenlijke bijdrage aan de berekende natriuminneming is betrekkelijk constant. Dit geldt niet allen voor de gehelle onderzoekspopulatie naar leeftijdscategorie en geslacht doch eveneens voor de personen met de hoogste dan wel laagste urine natriumexcretie. De berekende molaire natrium/kalium ratio bedraagt ongeveer 7 . Relateert men de "bijdrage" van alle nagevraagde voedingsmiddelen aan de totale natriumuitscheiding, dan blijkt dit op gemiddeld $54 \%$ neer te komen. Voor kalium blijkt deze juist meer dan $100 \%$ hetgeen op een overschatting wijst van de kaliumgehalten in de voedingsmiddelentabel. Gezien het belang van de alledaagse voedingsmiddelen bij de natriuminneming zal beïnvloeding van de zoutconsumptie geen eenvoudige opgave zijn. Temeer daar deze niet alleen gemiddeld te hoog is doch tevens een sterke intra-individuele variabiliteit vertoont. Daarnaast zijn er goede gronden aanwezig om aan te nemen dat met name de ongunstige natrium/kalium ratio van de dagelijkse voeding mede debet is aan de ontsporing wan de fysiologische bloeddrukregulatie. Gesteld wordt dat kennis van de onevenwichtige verhouding van de hoeveelheden natrium en 
98

kalium in de voeding van essentiele betekenis is voor de primaire en secundaire preventie van hypertensie.

Gepleit wordt voor een voorwaardescheppend voedingsbeleid van de overheid gericht op beperking van natriumgebruik, werhoging van kaliumgebruik en wooral verlaging van de natrium/kalium ratio. 


\section{SUMMARY}

The dailly intake of sodium by people living in the industrialised parts of the world exceeds their physiological needs. The consumption of potassium is, on the contrary, relatively low. Sodium and potassium, closely connected with calcium, and according to all probability also magnesium, are apparently of essential importance for the regulation of blood pressure. Disturbance of the cellular interactions of the mentioned ions results in the narrowing of the arterioles. The increase in peripheral resistance of the blood vessels becomes manifest as a factor increasing blood pressure. Far from all epidemiological studies do corroborate due to the strong intra-individual variability and confounding variables - this salt-blood pressure theory. Yet there seems to be a consensus about the desirability not to let salt consumption exceed 5 or 6 grams per day.

The levels of the daily sodium and potassium consumption by the population are not known. Knowledge with regard to this is important, to be able to calculate the population risk of high salt consumption. Since mild hypertension is an extensive health problem that should be tackled in a non-pharmacological way, it is of essential interest to be informed about the degree of the two risk factors par excellence in this matter, i.e. overweight and excessive consumption of kitchen salt. The general practitioner, accepting primary responsibility in the fight against hypertension should therefore acquire insight into the presence of the risk factors mentioned above among his patients as well as about the levels of their blood pressure.

In Brielle a descriptive, exploratory investigation is set up in 1981. The aim of this study was to gather information among the adult population about the extent of the consumption of salt and possible factors that might influence it. From some $59 \%$ of the 1500 people out of the sample - which is taken in an aselect way - workable data have been gathered. Of that number 411 were men and 477 women. Besides personal data such as age and sex, inquiries concerned socio-economic background, possible presence of a hereditary (family) history of cardiowascular diseases and hypertension, the use of medicines and diet. Height, weight and knee-width, as well as pulse frequency and blood pressure have been measured. Since the sodium and potassium content in the urine during a period of 24 hours reflects, at group level, the intake of these 
electrolytes by that group, participants were asked to collect their urine over a period of 24 hours. At the same time the extent of the excretion of calcium, magnesium and creatinine in the collected urine samples is measured. On the basis of a food enquiry, an attempt is made to determine the volume of the daily consumption of a number of current foodstuffs. The content of sodium, potassium, calcium and magnesium of the consumed foodstuffs covered by the survey has been calculated. Finally, after the end of the study, about $12 \%$ of the participants is requested to again collect their urine over a period of 24 hours. By comparing the first test results with the second, knowledge is gained about the intra-individual variability of these urinary parameters.

The average Quetelet-index of the male participants shows a nonsignificant difference from that of the female ones, respectively $25 \pm 3$ and $25 \pm 4 \mathrm{Kg} / \mathrm{m}^{2}$. In total $16 \%$ of the men and $22 \%$ of the women have a Quetelet-index $\geqslant 28 \mathrm{Kg} / \mathrm{m}^{2}$.

According to the results of blood pressure measurement executed once only, $10 \%$ of participants shows a figure of $\geqslant 160 \mathrm{~mm} \mathrm{Hg}$ systolic and/or $95 \mathrm{~mm} \mathrm{Hg}$ diastolic.

The average sodium excretion in the 24-hours urine varies, dependant on the age for male participants from $124 \pm 46$ to $185 \pm 90 \mathrm{mmol}$. For the female participants these values vary from $108 \pm 54$ to $145 \pm 64 \mathrm{mmol}$. The average potassium excretion for male participants in the 24-hour urine test varies, dependant on the age from $65 \pm 19$ to $96 \pm 27 \mathrm{mmol}$. For female participants these values vary from $57 \pm 18$ to $71 \pm 17 \mathrm{mmol}$. The average calcium excretion in the 24-hour urine, for male participants varies from $3,3 \pm 2,1$ to $5,5 \pm 2,3 \mathrm{mmol}$. For females the range is $3,0 \pm 1,9$ to $4,5 \pm 2,4$ mmol. The average magnesium excretion in the 24 -hour urine varies for male from $4,0 \pm 1,2$ to $5,3 \pm 1,4 \mathrm{mmol}$. For females the range is $3,3 \pm 1,3$ to $4,3 \pm 1,4 \mathrm{mmol}$. The average creatinine excretion in the 24 -hour urine, dependant on the age, for male varies from $11,5 \pm 2,5$ to $16,6 \pm 4,2 \mathrm{mmol}$. For female participants these values vary from $9,0 \pm 2,9$ to $12,5 \pm 2,5$ mmol.

A percentage distribution of the amounts of sodium excretion shows that $87 \%$ of the male and $75 \%$ of the fermale participants are reaching levels of $\geqslant 100 \mathrm{mmol}$, while $26 \%$ of males and $13 \%$ of females have a sodium excretion in the $\geqslant 200 \mathrm{mmol}$ range. Those exhibiting high sodium excretions belong principally to the younger age groups. A percentage distribution of the figures for potassium excretion shows $81 \%$ of the male and $95 \%$ of the female participants having a urinary rate of $\leqslant 100 \mathrm{mmol}$ during the 24 hours. Younger participants have a somewhat higher potassium excretion than older ones. 
The calculated sodium/potassium ratio does not differ significantly between male and femalle participants and shows an average of $2,2 \pm 0,9$. Likewise, the age factor proved to be of minor practical interest. The percentage distribution of the molar sodium/potassium ratio shows that $99 \%$ of the participants reaches a value of $\geqslant 1,82 \% \geqslant 2$ and $32 \% \geqslant 3$, while $9 \%$ has a sodium/potassium ratio of $\geqslant 4$. It is evident that the contribution of sodium to high ratios is stronger than to the more favourable sodium/potassium balances. For potassium the reverse is the case.

Applying inorthogonal variance analysis the influence has been measured based of the following independant variables: sex, age, day of urine collection, socio-economic status, history concerning cardio-vascular diseases as well as hypertension, use of diuretics or other anti-hypertensives as well as following a low sodium diet. Simply age and sex, and to a lesser degree the day of urine collection, have significant influence on this. The percentage of variance fully explained by independant variables is, moreover generally low. A strong positive correlation has however been established between the value of the Quetelet-index and the value of the sodium and potassium excretions in the 24-hour urine and blood pressure as well as, albeit to a lesser degree, the sodium/potassium ratio.

The difficulty in determining individual sodium intake on the basis of the 24-hour urine test is illustrated by the calculated intra-individual variability. It has been calculated that at least 11 measurements on a person must be executed to bring the standard deviation of the mean within $10 \%$ of the mean individual value. For potassium in this respect 4 measurements are necessary. Within the individual person the variation coefficient for creatinine excretion is $15 \%$. Two measurements must be executed concerning one person to be able to make a reliable statement on the individual creatinine excretion. This is why this parameter is of only minor value in assessing the reliability of the urine collection.

The average sodium and potassium excretions from the second urine measurement are significantly lower than the results of the first. A changed pattern in food intake seems to be the underlying cause of this outcome. The molar sodium/potassium ratio calculated from the 24-hour urine is established as the more stable factor. The results of the first and the second measurement do not differ significantly from each other and show a high correlation.

The food inquiry provides an insight into the habitual daily consumption of ten current foodstuffs. The average sodium content of the consumed food varies according to the age for male participants between 74 and $114 \mathrm{mmol}$ per day. For the female participants these values are 
varying between 55 and $77 \mathrm{mmol}$. The average potassium content varies according to the age for male participants between 83 and $98 \mathrm{mmol}$ per day. For female participants these values vary between 72 and $82 \mathrm{mmol}$. The average calcium content varies according to the age for male participants between 24 and $34 \mathrm{mmol}$ per day. For female participants these values vary from 21 to $28 \mathrm{mmol}$. The average magnesium content according to the age for male participants varies from 9 to $11 \mathrm{mmol}$ per day. For female participants these values are vaying between 8 and $9 \mathrm{mmol}$. Closer examination of the contribution of the different foodstuffs to sodium intake reveals that above all bread, cold meats and cheese are of importance. Their joint contribution to the calculated sodium intake is relatively constant. This applies not only to the whole inquiry population according to age group and sex but also to individuals with either the highest or the lowest urinary sodium excretion. The calculated molar sodium/potassium ratio appears to be about 7 . If one compares the "contribution" of the few selected foodstuffs to the total sodium excretion, this proves to be $54 \%$ on average.

Considering the important role of daily foodstuffs in total sodium intake, reducing of salt consumption will be very difficult. Moreover this intake is not only high on an average but shows a strong intra-individual variability as well.

Besides this, there are good grounds to assume that particularly the unfavourable sodium/potassium ratio in daily food is one of the causes of disturbing the regulation of the physiological blood pressure. Knowledge of the imbalance between the amounts of sodium and potassium in the daily food intake must be considered to be of essential significance for primary and secondary prevention of hypertension. A supporting nutrition policy by the government is advocated to improve the sodium/potassium ratio in the daily diet. 


\section{LITERATUUR}

1 Gezondheidsraad. Advies inzake epidemiologie en preventie van ischemische hartziekten. 's-Gravenhage: Staatsuitgeverii, 1984.

2. Voedingsraad. Voeding in relatie tot coronaire hartziekten. is-Giravenhage: Staatsuitgeverij, 1982.

3 World Health Organization. Arterial hypertension. Technical Report Series 628. Geneva, 1978 .

4 Centraal Bureau voor de Statistiek in samenwerking met de raad voor gezondheidsresearch TNO. Hart- en vaatziekten. Onvang en maatschappelijke betekenis. 's-Gravenhage: Staatsuitgeverij, 1980.

5 Miettinen OS. Risk indicators for coronary heart disease. Hart Bulletin 1973; 4: 64-70.

6 Stiggelbout W. Risicofactoren en preventie. Hart Bulletin 1983; 14: 19-23.

7 Julius $\mathrm{S}$, Hansson L, Andrén L, Gubrandsson T et al. Borderline hypertension. Acta Med Scand 1980; 208: 481-9.

8 Gezondheidsraad. Advies inzake hypertensie. 's-Gravenhage: Staatsuitgeveritj, 1983.

9 World Health Organization. Prevention of coronary heart disease. Technical Report Series 678. Geneva, 1982

10 Leeuw $\mathbb{P W}$ de, Birkenhäger WH. De betekenis van systolische hypertensie. Ned Tijdschr Geneeskd 1984; 128: 160-5.

11 Birkenhäger WH. De bestrijding van lichte en matige hypertensie: een wenkend perspectief. Ned Tijdschr Geneeskd 1980;124: 749-51.

12 Rose G. Strategy of prevention: Lessons from cardiovascular disease. Br Med J 1981; $282: 1-12$.

13 Blackburn $\mathbf{H}$. The primary prevention of high blood pressure - a population approach. Annals of Clinical Research 1984; 16 suppl 43: 11-7.

14 Stamler R. Stamler J, Gosch FC, McDonald AM. Primary prevention of hypertension - a randomized controlled trial. Annals of Clinical Research 1984; 16 supl $43: 136-42$.

15 Birkenhager WH. Bloeddrukverlagende behandeling ter beperking van cardiovasculaire complicaties van hypertensie. Ned Tijdschr Geneeskd 1985; 129" $2341-3$.

16 Pell S, Fayerweather WE. Trends in the incidence of myocardial infarction and in associated mortality and morbidity in a large employed population, 1957-1983. N Engl J Med 1985; 312: 1005-11.

17 Rose G. Hypertension: problems and policy. Hart Bulletin Supplement 1, 1985: 16: $21-3$.

18 World Health Organization. Primary prevention of essential hypertension. Technical Report series 689. Genewa, 1983.

19 Beard TC, Cooke JM, Gray WR, Barge R. Randomized controlled trial of a no-added-sodium diet for mild hypertension. Lancet 1982 ; ii: 455-9.

20 Hypertension Detection and Follow-up Program Cooperative Group. Five-year findings of the hypertension detection and follow-up program. JAMA 1979;242: $2562-77$. 
21 Management Commitee. The Australian therapeutic trial in mild hypertension. Lancet 1980; i: 1261-7.

22 WHO/ISH Mild hypertersion liaison Committee. Trials of the treatment of mild hypertension. An interim analysis. Lancet 1982; i: 149-56.

23 Lulbsen J, Man in"t Veld A.J. Milde hypertensie: behandellen of niet? Vraag eri antwoord Journalal $1982: 2: 14+14 \mathrm{~A}$.

24 Pickering $G$. Normotension and Hypertension: The Mysterous Viability of the False. Am J Med 1978; 65: 561-3.

25 Kottke TE, Puska P. Tuomilehto J, Nissinen A. Projected population effects of a nutritional blood pressure intervention on death tates from cardiovascular disease. Annals of Chinical Research 1984; 16 suppl 43: 170-3.

26 Birkenhidger WH, Leeu PW de. Bloeddruk en de macht van het getal Tijdschrift voor diagnose informatie en medische statistiek. 1982; nummer 1 .

27 Ree IW van. Het Nijmeegs interventieproject. Acadomisch Proefschrift, Nijmegen, 1981.

28 Feen IAE van der. Hypertensie, een uitdaging aan de huisarts. Academisch Proefschrift, Rotterdam, 1977.

29 Bekker JP. Hypertensie interventie analyse te Krimpen aan den IJssel. Academisch Proefschrift, Rotterdam, 1983.

30 Zumkley H. Die Behandlung der Hypertonus mit Kochsalzarmer Kost. Ernährungs-Utmschau 1984; 31: 305-8.

31 Birkenhäger WH, Leeuw PW de. Grammen zout en millimeters kwik. Ned Tijdschr Geneeskd 1982; 126: 1586-90.

32 Walker WG. Relationships between sodium and potassium intake and blood pressure. In: Kesteloot H, Joossens JV ed. Epidemiology of arterial blood pressure. The Hague/Boston/London: Martinus Nijhoff Publishers, 1980: 297-309.

33 Anonymus. Diet and hypertension. Lancet 1984; ii: 671-3.

34 Ree JW van, Gerwen W yan, Hoogen $H$ van den. Interventie bij een verhoogd risico op hart-en vaatziekten. 2. Resultaten op langere termijn bij de behandeling van hypertensie. Huisarts en Wetenschap 1985; 28:53-8.

35 Bulpitt CJ. Cation consumption and blood pressure. Neth J Med 1984; 27: 95-100.

36 Langford HG. Potassium in hypertension. Post Grad Med 1983: 73: No 1.

37 Langford HG. Diettary Potassium and Hypertension: Epidemiologic Data Annals of Internal Medicine 1983; 98 (part 2): 770-2.

38. Sturmans F. Epidemiologie. Nijmegen: Dekker \& van de Vegt, 1984.

39 Voedingsraad. Adwies richtlijnen goede voeding. 's-Gravenhage: Stantsuitgeverij,

40 Strasser T. Prevention of hypertension - has the future started? Annals of Climical Research 1984; 16 suppl 43: 179-83.

41 Heidrich FE, Bergman JJ. Physician knowledge of sodium content of common foods. J Fam Prac 1982; 14: 693-7.

42 Lang $C L$, Weinberger MH, Miller IZ. Dietary counseling results in effective dietary sodium restriction. J Am Diet Ass 1985;85; 477-9

43 Melker RA de Anticiperende geneeskunde. Ned Tijdschr Geneeskd 1984; 128 950-4.

44 Fregly MS. Salt and social behavior. In: Kare MR, Fregly MJ, Bernard RA ed. Biological and Behavioral aspects of salt intake. New York/Londen/Toronto. Academic Press, 1980: 3-11. 
45 Meneely GR. To salt or not to salt, that is the question: A discussion with digressions. In: Fregly MJ, Kare MR ed. The role of salt in cardiovascular hypertension. New York/London/Paris: Academic Press, 1982: 175-87.

46 Meneely GR, Battarbee HD. High sodium-low potassium environment and hypertension. Am J Card 1976; 38: 768-85.

47 Davidson S, Passmore R, Broch JF, Truswell AS. Human nutrition and dietetics. 7 th ed. Edinburgh London and New York: Churchill Livingstone, 1979.

48 Battarbee HD, Meneely GR. The toxity of salt. Crit Rev Toxicol 1978; 5: 355-76.

49 Wilson TW. History of salt supplies in West Africa and blood pressures today. Lancet 1986 ; i: 784-6.

50 Allen AM, Stamler $J$, Stamler $R$, Gosch $F_{3}$ Cooper $R$, Liu $\mathbb{K}_{*}$ Trevisan $M$. Observational and interventional experiences on dietary sodium intake and blood pressure. In: Fregly MJ, Kare MR ed. The role of salt in cardiovascular hypertension. New York/London/Paris. Academic Press, 1982: 63-78.

51 Voedingsraad. Interimadvies Vermindering gebruik keukenzout. 's-Gravenhage: Staatsuitgeverij, 1982.

52 Voedingsraad. Vermindering gebruik keukenzout. 's-Gravenhage: Staatsuitgeverij, 1986.

53 Blok PJ. Brielle als vrije en bloeiende handelsstad in de $15^{\mathrm{e}}$ eeuw. In: Bijdragen voor Vaderlandsche Geschiedenis en Oudheidkunde. "s-Gravenhage: Martinus Nijhoff 1907, vierde reeks; 7-66.

54 Jager $\mathbb{H}$ de. De middeleeuwsche Keuren der stad Brielle. In: Werken der vereniging tot uitgave der bronnen van het oude Vaderlandsche recht. 'sGravenhage: Martinus Nijhoff 1901, tweede reeks; 190-1.

55 Boxhorn MZ van. Chroniick van Zeelandt. Reygersbergen red. Leiden: Boxe van der, 1644: 35-8.

56 Forsythe RH, Miller R. Salt in processed foods. In: Kare MR, Fregly MJ, Bernard RA ed. Biological and Behavioral aspects of salt intake. New York/London/Toronto. Academic Press, 1980: 221-8.

57 Joossens JV. De epidemiologische betekenis van het keukenzout. In: Gerlings PG, Birkenhäger WH, Es JC van, Joossens IV red. Het Medisch Jaar 1978. Utrecht: Bohn, Scheiltema \& Holkema, 17-31.

58 Bertino M, Beauchamp GK, Engelman K, Kare MR. Dietary sodium and salt taste. In: Fregly MJ, Kare MR. ed The role of salt in cardiovascular hypertension. New York/London/Paris, Academic Press, 1982: 145-54.

59 Paque C. Saharan Bedouins and the salt water of the Sahara: A model for salt intake. In: Kare MR, Fregly MJ, Bernard RA ed. Biological and Behavioral aspects of salt intake. New York/London/Toronto, Academic Press, 1980: 31-47.

60 Frijters JER. De waarneming en de beleving van de geur en smak van voedingsmiddelen. In: Kroes R, Claesen H, Hermus RJJ, Kroonenberg CC, Damme $J$ van, Ree JW van, red. Voeding in de praktijk. Utrecht: Bohn, Scheltema \& Holkema, 1984; IV-A2 1-9.

61 Engstrom AM, Tobelmann RC. Nutritional Consequences of Reducing Sodium Intake. Annals of Internal Medicine 1983; 98 (part 2): 870-2.

62 Wijn JF de, Staveren WA van. De voeding van elke dag. 2e ed. Utrecht: Bohn, Scheltma \& Holkema, 1980.

63 Hautvast JGAJ, Hermus RJJ. Een voedsel- en voedingsbeleid in Nederland; bestrijding van de gevolgen van de welvaart I + II. Ned Tijdschr Geneeskd 1979; 123: $939-44+975-85$. 
64 The British Nutrition Foundation. Salt in the diet. BFN Brieting paper No 2. 1981; 6: 171-88.

65 Alschu AM, Gromet JK. Sodium intake and sodium sensitivity. Nutrition Reviews $1980 ; 38: 393-402$.

66 American Academy of Pediatrics. Committee on nutrition. Salt intake and eating patterns of infants and children in retation 10 blood pressure. Pediatrics $1974 ; 53$ : 115-21.

67 Sasaki N. Epidemiological studies on hypertension in Northeast Japan. In: Kesteloot H, Joossens JV ed. Epidemiology of arterial blood pressure. The Hague/Boston/London: Martinus Nijhof Publishers, 1980: 367-77.

68 Kesteloot H. Epidemiologisch onderzoek nat de verdeling van de cardiovasculaire risicofactoren in Belgiè en Korea. Hart Bulletin 1980;11:119-24.

69 Haar $F$ van der, Kromhout D. Food intake, nutritional anthropometry and blood chemilcal parameters in 3 selected Dutch schoolchildren populations. Academisch Proefschrift, Wageningen, 1978.

70 Balogh M, Kahn HA, Medalie JH. Random repeat 24-hour dietary recalls. Am J Clini Nutr $1971 ; 24: 304-10$.

71 Loo-Bunnik LM wan de, Staveren WA van. Methodieken voor individueel gericht anderzoek nar de samenstelling wan het voedselpakket. Voeding 1973; 34: 507-17.

72 Young CM, Chalmers FW, Church HN et al A comparison of dietary study methods. J Am Dietetic Ass 1952; 28: 124-8 + 218-21.

73 Staveren A van, Hulshof KFAM. De voedingsanamnese in het voedingsonderzoek, mogelijkheden en beperkingen. Voeding 1980; 41: 229-33 "

74 Vet HCW de. De Voedingsanamnese. In: Kroes $\mathrm{R}$, Claesen $\mathrm{H}$, Hermus RJJ, Kroonenberg CC, Damme J van, Ree JW van, red. Voeding in de praktijk. Utrecht: Bohn, Scheltma \& Holkema, 1984; V-A1 1-11.

75 Breedveld BC, Bovenkamp $\mathrm{P}$ wan de, Andriessen-Bos J et al. Natrium- en kaliumgehalte in een aantal voedingsmiddelen. Woeding 1980; 40:234-7.

76 Nederlandse Voedingsmiddelentabel. $34^{\circ}$ ed. 's-Gravenhage: Voorlichtingsbureau voor de Voeding, 1983.

77 Bosman $\sqrt{ }$, Flach M. Zouttoevoeging bij de bereiding en consumptie van de warme maaltijd. Landbouwhogeschool, Vakgroep Humane Voeding. Rapport nr. 81.50. Wageningen, 1981 .

78 Tanskanen A. Salt intake and blood pressure. Publications of the University of Kuopio Community health. Series original reports $2 / 1982$.

79 Pietinen P, Tuomilehto I. Estimating sodium intake in epidemiological studies. In: Kesteloot H, Joossens JV ed. Epidemiology of arterial blood pressure. The Hague/Boston/Londlon: Martinus Nijhoff Publishers, 1980: 29-44.

80 World Heglth-Organization. Sodium, Chlorides and the conductivity in drinkingwater. Report on a WHO working group. Copenhagen, 1979.

81 Joossens IV, Claessens J, Geboers $J$, Claes JH. Electrolytes and creatinine in

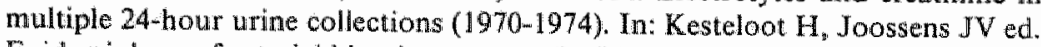
Epidemiology of arterial blood pressure. The Hague/Boston/London: Martinus Nijhoff Publishers, 1980: 45-63.

82 Pietinen PI, Findley TW, Clausen JD, Finnerty FA jr, Altschul AM. Studies in Community nutrition: Estimation of sodium output. Prev Med 1976; 5; 400-7.

83 Dauncey MJ, Widdowson EM. Urinary excretion of calcium, magnesium, sodium, and potassium in hard and soft water areas. Lancet 1972; $1: 711-4$. 
84 Pietinen PI, Wong O, Altschul AM. Electrolyte output, blood pressure, and family history of hypertension. AM J Clin Nutr 1979; 32: 997-1005.

85 Liu $K$, Cooper $R$, Mckeever $J$ et al. Assessment of the association between habitual salt intake and high blood pressure: methodological problems. Am $J$ Epidem 1979; 110: $219-26$.

86. Liu K, Stamler J. Assessment of sodium intake in epidemiological studies on blood pressure. Armals of Glinical Research 1984; 16 suppl 43:49-54.

87 Sanchez-Castillo CP, Warrender S, Whitehead T, James WPT. A nowel technique for assessing the sources of dietary sodium. Annals of Clinical Research 1984;16 suppl 43:44-8.

88. Forbes GB, Bruining GJ. Urinary creatinine excretion and lean body mass. An $\mathbb{J}$ Clin Nutr 1976; 29: 1359-66.

89 Webster J, Garrow JS. Creatinine excretion over 24 hours as a measure of body composition or of completeness of urine collection. Human Nutrition: Clinical Nutrition $1985 ; 39 \mathrm{C}: 101-6$.

90 Dokkum W van. Dietary recommendations and mineral utilization. Academisch Proefschrift, Amsterdam, 1984.

91 Williams DRR, Bingham SA. Sodium and potassium intakes in a representative population sample: estimation from $24 \mathrm{~h}$ urine callections knowin to be complete in a Cambridgeshire village. $\mathbb{B} \mathbb{J}$ Nutr 1986; 55: 13-22.

92 Jonxis JHP. Eiwit en fosfaat in onze woeding en de voortschrijdende ontkalking van het skelet wan wrouwen na de menopauze. Ned Tijdschr Geneeskd 1985; 129: $110-3$.

93 Jonxis JHP, Kleingeld PH, Reiking WG, Weljers-Oldenbandringh GH. De invloed van de hoeveelheid eitwit en fosfaat in de voeding op de calciumuitscheiding met de urine bij oudiere wrouwen. Voeding 1985; 46: 68-73.

94 Berensteyn ECH van, Winkeldermaat HJ, Have-Witjes A ten, Neeter R. De voeding en de voedingstoestand van vifftig tot zestigjarige vrouwen in Ede: een risicofactor van postmenopauzale osteoporose? Voeding 1985; 46:258-61.

95 Wijn JF de, Hekkens WThJM. Fysiologie van de voeding. Utrecht: Bohn, Scheltema \& Holkema, 1985.

96 Oliver WJ. Sodium homeostasis and low blood pressure populations. In: Kesteloot H, Joossens IV ed. Epidemiology of arterial blood pressure. The Hague/Boston/London: Martinus Nijhoff Publishers; 1980: 229-41.

97 Forbes $\mathrm{RJ}$ red. Het zout der aarde. NV Koninklijke Nederlandse Zoutindustrie. Hengelo, 1968.

98 Hunt JC, Cooper $T$, Frolich E, Kaplan NM, Laragh JH et al ed. Hypertension Update. Health Learning Systems Inc. Bloomfield, 1980.

99 Ram CVS, Punzi HA, Chia BL. Drie geneesmiddelen woor de behandeling van therapie-resistente hypertensie. Moderm Medicine 1985; 9: 491-8.

100 Frolich ED. Mechanisms contributing tot high blood pressure. Annals of Internal Medicine 1983; 98 (part 2): 709\%14.

101 Reisin $\mathbb{E}$, Abell R, Modan M, Silverberg DS, Eliahou HE, Modan B. Effect of weight loss without salt restriction on the reduction of blood pressure in overweight hypertensive patients. N Eng IMed 1978; 298: 1-6.

102 Contreas RJ. Peripheral neural changes associated with sodium deprivation. In: Kare MR, Fregly MJ, Bernard RA ed. Blological and Behavioral aspects of salt intake. New York/London/Toronto. Academic Press, 1980: 299-315.

103 Tannen R. Effects of potassium on blood pressure control. Annals of Internal Medicine 1983; 98 (part 2): 773-80. 
104 Freis ED. Silt., wolume and the prewention of hypertenston. Circ 1976; 53:589-95.

105 Borst JGG, Borstede Geus A. Hypertension explained by Starling's theory of circulatory homoeostasis. Lancet 1963; i. 677-82.

106 Ambard L, Beaujard E. Causes de lthypertension arterielle Arch Gen de Med 1904; 1: 520-33.

107 Laragh JH, Pecker MS. Dietary sodum and essential hypertension: Some myths. hopes, and truths. Annals of Intermal Medicine 1983; 98 (part 2): 735-43.

108 Genest J. Volume hormones and blood pressure. Arnals of Internal Medicine 1983; 98 (part 2): 744-9.

109 Flear CTG, Gill GV Hyponatraemia: Mechanisms and management. Lancet 1981; î: 26-31.

110 London GL, Lewenson JA, Simon AC et al. Fluid volumes and the kidney in essertial hypertension. Neth $J$ med $1984 ; 27$ : 112-6.

111 Man in 't Veld AJ, Wenting GJ, Schalekamp MADH. Een (hemo) dynamische visie op de relatie zout en hypertensie. Hart Bulletin $1983 ; 14: 101-8$.

112 Birkenhager WH. De dynamiek van essentiele hypertensie. Ned Tijdschr Geneeskd 1976; 120; 1076-82.

113 Tobian $\mathrm{L}$. Human essential hypertension: Implications of animal studies. Annals of Internal Medicine $1983 ; 98$ (part 2): 729-34.

114 Koster M. Hypertensie en decomperisatio cordis. Hart Bulletin 1983; 14: 109-12.

115 Blaustein MP, Hamlyn JM. Role of a natriuretic factor in essential hypertension: A hypothesis. Annals of Internal Medicine 1983; 98 (part 2): 785-92.

116 Leeuw PW de, Birkenhäger WH. Sodium, adrenergic activity and bloodpressure. Neth J Med 1983;26:283-7.

117 Luft FC, Rankin LI, Henry DP, Weinberger MH. Sodium and the effects of norepinephrine. In: Fregly MJ, Kare $M R$ ed. The role of salt in cardiovascular hypertension. New York/London/Paris. Academic Press, 1982: 267-80.

118 Weinberger MH, Luft FC, Henry DP. The role of the sympathic nervous system in the modulation of sodium excretion. In: Fregly MJ, Kare MR ed. The role of salt in cardiovascular hypertension. New York/London/Paris. Academic Press 1982: 281-91.

119 Friedman SM. Monovalent and divalent ions in vascular tissue. Annals of Internal Medicine 1983; 98 (part 2): 753-8.

120 Haddy FJ. Sodium-Potassium pump in low-renin hypertension. Annals of Internal Medicine 1983; 98 (part 2): 781 1-4.

121 Friedman SM. The transmembrane distribution of sodium, potassium, and water in vascular smooth muscle and the hormonal regulation of vascular tone and reactivity. In: Fregly $\mathrm{MJ}$. Kare $\mathrm{MR}$ ed. The role of salt in cardiovascular hypertension. New York/London/Paris. Academic Press, 1982: 385-401.

122 Haddy $F$, Huot $S$, Clough $D$ et al. The role of an Ouabain-like Humoral Factor in the Genesis of low Renin Hypertension. In: Fregly MJ, Kare MR ed. The role of salt in cardiovascular hypertension. New York/London/Paris. Academic Press, 1982; 403-16.

123 Haddy FJ. Mechanism, prevention and therapy of sodium-dependent hypertension. Am J med 1980; 69; 746-58.

124 McCarron DA. Calcium and Magnesium nutrition in human hypertension. Annals of Internal Medicine 1983; 98 (part 2): 800-5.

125 Cohn JN. Calcium, vascular smooth muscle, and calcium entry blockers in hypertension. Annals of Internal Medicine 1983; 98 (part 2): 806-9.

126 Blaustein MP. Sodium-callcium exchange in vascular smooth muscle: Key to the 
genesis of essential hypertension. In: Fregly MJ, Kare MR ed. The role of salt in cardiovascular bypertension. New York/London/Paris. Academic Press, 1982: $417-23$.

127 Breemen $C$ van, Kolber M, Aaronson P. Effects of changing the gradient on calcium fluxes in smooth muscle. In: Fregly MJ, Kare MR ed. The role of salt in cardiovascular hypertension. New York/London/Paris. Academic Press 1982 : 425-41.

$128 \mathrm{McC}$ arron DA. Low serum concentrations of ionized calcium in patients with hypertension. N Eng J Med 1982; 307: 226-8.

129 Parrott-Garcia M, McCarron DA. Calcium and hypertension. Nutr Rev 1984:42: 205-13.

130 Karppanen $\mathrm{H}$. Role of electrolytes and digitalis-like activity in hypertension: effects of digitoxin, sodium, potassium and magnesium on blood pressure.. Annals of Clinical Research 1984; 16 suppl 43: 62-6.

131 Ryan MP, Brady HR. The role of magnesium in the prevention and contral of hypertension. Annals of Clinical Research 1984; 16 suppl 43: 81-8.

132 Hülsmann WC. Voeding en cholesterolmetabolisme. I. Cholesterol, calcium en valuand. Voeding 1986; 47: $2-5$.

133 Ophir $\mathrm{O}$, Peer $\mathrm{G}$, Gilad J et al. Low blood pressure in vegetarians: the possible role of potassium. Am J Clin Nutr 1983; 37: 755-62.

134 MacGregor $\mathrm{G}$, Wardener $\mathrm{H}$ de. Is a circulating sodium transport inhibitor involved in the pathogenesis of essential hypertension? In: Fregly MJ, Kare MR ed. The role of salt in cardiovascular hypertension. New York/London/Paris. Academic Press. 1982; 331-43.

135 Morgan TO, Fitzgibbon W, Myers JB. The interrelationship between sodium intake, membrane sodium transport and high blood pressure Neth J Med 1984; 27: 101-4.

136 Lijnen P, Fagard R, Groeseneken D, M'buyamba-Kabangu JR, Staessen I, Lissens W, Amery A. Intracellular concentration and transmembrane fluxes of sodium and potassium in erythrocytes of normal male subjects. Effect of family history of hypertension and race. Neth J Med 1984; $27: 105-11$.

137 Fujita $T$, Delea $C S$, Batter FC. The role of the Renin-Angiotensin and prostaglandin systems in salt-sensitive and nonsalt-sensitive hypertension in man. In: Fregly MJ, Kare MR ed. The role of salt in cardiovascular hypertension. New York/London/Paris. Academic Press, 1982: 207-19.

138 Dzau VJ, Packer M, Lilly LS al. Prostaglandins in severe congestive heart: failure. N Eng J Med 1984; 310: 347-51.

139 Wardener HE de, Clarkson EM, Bitensky 1 , MacGregor GA, Alaghband-Zadeh $J$, Chayen $J$. Effect of sodium intake on ability of human plasma to intibit renal $\mathrm{Na}^{+}-\mathrm{K}^{+}$- adenosine triphosphate in vitro. Lancet $1981 ; \mathrm{i}: 411-2$.

140 MacGtegor GA, Smith SJ, Markandu NE, Banks RA, Sagnella GA. Moderate potassium supplementation in essential hypertension. Lancel 1982; ii: 567-70.

141 Mickelsen O, Makdani D, Gill JL, Frank RL. Sodium and potassium intakes and excretions of normal men consuming sodium chloride or a $1: 1$ mixture of sodium and potassium chlorides. Am J Clin Nutr 1977; 30: 2033-40.

142. Treasure $J$, Ploth $D$. Role of dietary potassium in the treatment of hy pertension. Hypertension 1983; 5: 864-72.

143 Tobian L. Dietary salt (sodium) and hypertension. Am J Clin Nutr 1979; 32: $2659-62$. 
144 Tobian L. The relationship of salt to hypertension. Am J Clin Nutr 1979; 32: $2739-48$

145 Zha GS, Li DY, Zhu DL, Kong DW, Qian YW, Li DP. Cellular mechanism relating sodium and potassium to hypertension. Annals of Clinical Research 1984 ; 16 suppl: $55-61$.

146 Amternius $\mathrm{AC}$, Dunning $\mathrm{A} J$, Snellen $\mathrm{HA}$ ed. Blood pressure measurement and systemic hypertension. 2nd Einthoven meating. Breda; Medical World Press, 1981.

147 Simpson FO. Salt and bypertension: a sceptical review of the evidence. Clin Sci $1979 ; 57: 4635-80$ s.

148 Swales JD. Dietary salt and hypertension. Lancet $1980 ;$ i: 1177-9.

149 Laar A van"t, Birkenhäger WH. Hypertensie en zoutgebruk. In: Querido A, Roos $J$ red. Controversen in de geneeskunde. Utrecht, Wetenschappelijke uitgeverij Bunge, 1980: 44-56.

150 Finn R, McConnochie K, Box DEO, Fennerty AG, Green JR. Blood pressure and salt intake: an intra-population study. Letter. Lancet 1981; i: 1097.

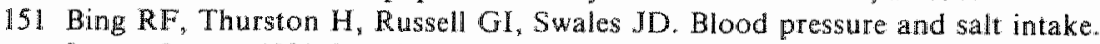
Letter. Lancet 1981; i: 1260 .

152 Watt $G$. Blood pressure and salt at table. Letter. Lancet 1981; i: 1205.

153 Williams DRR. Sall and hypertension. Letter. Lancet 1980; ii: 202.

154 Elliot P, Marmot M. International studies of salt and blood pressure. Annals of Clinical Research 1984; 16 suppl 43:67-71.

155 Kesteloot H. Kationen en bloeddruk. Ned Tijdschr Geneeskd 1985; 129:630-4.

156 Amery $A$, Bulpitt $C$, Fagand $R$, Staessen $J$. Does diet matter in hypertension? Europ Heart J 1980; 1: 299-308.

157 Drawber TR, Kannel WB, Kagan A, Donabedian RK, McNamara PM, Pearson G. Enivironmentall factors in hypertension. In: Stamler J, Stamler R, Pullmian TN ed. The epidemiology of hypertension. Proceedings of an international symposium: New York; Grune \& Stratton Inc, 1967: 255-88.

158 Kannel WB. Host and environmental determinants of hypertension. In: Kesteloot H, Joossens JV ed. Epidemiology of arterial blood pressure. The Hague/Boston/London: Martinus Mijhoff publishers, 1980: 265-95.

159 Tuomilehto J, Karppanen H, Tanskanen A, Tikkanen J, Vuori J. Sodium and potassium excretion in a sample of normotensive and hypertensive persons in eastern Finland. J Epid Comm Health 1980; 34: 174-8.

160 Schlierf G, Arab L, Schellenberg B, Oster P, Mordasini R, Schmidt-Gayk H, Vogel G. Salt and hypertension; data from the "Heidelberg study". Am J Clin Nutr 1980; 33:872-5.

161 MacGregor GA, Markandu ND, Best F, Elder D, Cam JM, Sagnella GA, Squires M. Double-blind randomised crossover trial of moderate sodium restriction un essential hypertension. Lancet 1982 ; ii: $349-54$.

162 Geerling J. Bloeddruk en caloim. Ned Tijdschr Geneeskd 1982; 126: 1884.

163 Kesteloot H. Urinary cations and blood pressure - population studies. Annals of Clinical Research 1984; 16 suppl $43: 72-80$.

164 Huige MC Onderzoek naar de betrouwbaarbeid wan de auscultatoire bloeddrukmeting an overwegend dikke bovenarmen. Introductie van een conische manchet. Academisch Proefschrift, Leiden, 1980.

165 Page LB. Epidemiologic evidence on the etiology of human hypertension and its possuble prevention. Am Heart J 1976; 91:527-34.

166 Valkenburg HA, Hofman A. Een epidemiologisch onderzoek naar de risico- 
indicatoren voor hart- en vatziekten (EPOZ) I + II. Ned Tijdschr Geneeskd $1980 ; 124: 183-95$.

167 Havlik RJ, Hubert HB, Fabsitz RR, Feinleib M. Weight and hypertension. In: Annals of Internal Medicine $1983 ; 98$ (part 2): 855-9.

168 Dustan H. Mechanisms of hypertension associated with obesity. Annals of Internal Medicine 1983; 98 (part 2): 860-4.

169 Deurenberg. P, Poppel G van, Hautvast JGAJ. Morbiditeit en subjectief welbevinden bij jonge volwassenen met overgewicht. Ned Tijdschr Geneeskd 1984: $128: 940-4$.

170 Gezondlaeidsraad. Adwies inzake adipositas. "s-Gravenhage: Staatsuitgeverij, 1984.

171 Tuck ML, Sowers J, Dornfeld L, Kledzik G, Maxwell M. The effect of weight reduction on blood pressure, renin activity, and plasma aldosteron levels in obese patients. N Engl J med 1981; 304: 930-3.

172 Gillum RF, Prineas J, Jeffery RW, Jacobs DR, Elmer PJ, Orlando Gomez MS, Blackburn H. Nonpharmacologic therapy of hypertension: The independent effects of weight reduction in overweight borderline hypertensive patients. Am Heart J 1983; 105: 128-33.

173 Koolen MI, Brummelen P van. Zoutgevoeligheid van de bloeddruk bij patienten met essentiële hypertensie. Hart Bulletin 1985; 16:115-21.

174 Grobbee DE, Hofman A. Alcohol en bloeddruk. Ned Tijdschr Geeneeskd 1985; 129:634-8.

175 Hofman A, Grobbee DE, Valkenburg HA. Een epidemiologisch onderzoek naar het verband tussen alcohol en bloeddruk. Ned Tijdschr Geneeskd 1985; 129 : $639-41$.

176 Klatsky AL, Friedman GD. The role of alcohol in the epidemiology of hypertension - is alcohol associated hypertension a common preventable disease? Annals of Clinical Research 1984; 16 suppl 43: 89-96.

177 Potter JF, Beevers DG. The possible mechanism of alcohol associated hypertension. Annals of Clinical Research 1984; 16 suppl 43: 97-102.

178 Lacono JM. Puska P, Dougherty RM. Studies on the effect of dietary fat on blood pressure. Annals of Clinical Research 1984; 16 suppi 43: 116-25.

179 Page LB. More proof of salt-hypertension link. JAMA 1977; 237: 1305-8.

180 Prior IAM, Evans, JG, Hervey HPB, Davidson F, Lindsey M. Sodium intake and blood pressure in two Polynesian populations. N Eng J Med 1968; 279: 515-20.

181 Page LB, Damon A, Moellering RC. Antecedents of cariovascular disease in six Solomon Islands societies. Circ 1974; 1132-46.

182 Knudsen KD, Iwai J, Dahl LK. Salt, Heredity, and Hypertension. In: Hypertension: Mechanisms \& Management. New York Grune \& Stratton. 1973: 111-7.

183 Komachi $Y$, Shimamoto T. Salt intake and its relationship to blood pressure in Japan. In: Kesteloot H, Joossens JV ed. Epidemiology of arterial blood pressure. The Hague/Boston/London: Martinus Nijhoff Publishers, 1980: 395-400.

184 Sever PS, Peart WS, Gordon D, Beighton P. Blood-pressure and its correlates in urban and tribal Africa. Lancet 1980; ii: 60-4.

185 Simpson FO, Waal-Manning HJ, Bolli P, Phelan EL, Spears GFS. Relationship of blood pressure to sodium excretion in a population survey. Clin Sci \& Mol Med 1978; $55: 373 \mathrm{~s}-375 \mathrm{~s}$.

186 Simpson FO, Nye ER, Bolli P et al. The Milton Survey: part 1, general methods, 
height, weight and 24-hour excretion of sodum, potassium, calcium, magnesiunt and creatinine. New Zealand Med I 1978; 87:379-82.

187 Simpson FO. Waal-Manning HJ, Bolli P, Spears GFS. The Milton Survey. 2. Blood pressure and heart rate. New Zealand Med J 1978; 88: 1-4.

188 Karwonen MJ, Punsar S. Sodium excretion and blood pressure of West and East Finns. Acta Med Scand 1977; 202:501-7.

189 Staessen J, Fagard R, Lijnen P, Amery A, Bulpitt C, Joossens JV. Salt and blood pressure in Belgium. I Epid Comm Health 1981;35:256-61.

190 Kesteloot $\mathrm{H}$, Park BC, Lee CS, Brems-Heyns, Joossens JV. A comparative study of blood pressure and sodium intake in Belgium and in Korea. In: Kesteloot $\mathrm{H}_{\text {p }}$ Joossens IV ed. Epidemiology of arterial blood pressure. The Haguet Boston/London: Martinus Nijhoff Publishers, 1980: 453-70.

191 Joossens IV, Willems J, Claessens J, Claes J, Lissens W. Sodium and hypertension. Proceedings International symposium Rimini 1970, 91-110.

192. Berg ten - Schaaf van der $J$. Onderzoek naar het verband tussen de bloeddruk en het zoutgebruik bij kinderen. Academisch Proefschrift, Groningen, 1979.

193 Burnstyn , Hornall D, Watchorn C. Sodium and potassium intake and blood pressure. Br Med J 1980; 537-9.

194 Hofman A. Blood pressure in childhood. Epidemiological probes into the aetiology of high blood pressure. Academisch Proefschrift, Rotterdam, 1983.

195 Hofman A, Hazebrock A, Valkenburg HA. A randomized trial of sodium intake and blood pressure in new born infants. JAMA 1983; 250: 370-3.

Ingelfinger JR. Sodium and blood pressure in infancy (Editorial). JAMA 1983; 250: $389-90$.

196 Richards MA, Espiner EA, Maslowski AH, Nicholls MG, Ikram H, Hamilton EJ, Wells JE. Blood pressure response to moderate sodium restriction and to potassium supplementation in mild essential hypertension. Lancet 1984; $\mathrm{i}$ : $757-61$.

197 Watt GCM, Edwards C, Hart JT, Hart M, Walton P, Foy CJW. Dietary sodium restriction for mild hypertension in general practice. Br Med J 1983; 286:432-6.

198 Bing RF, Swales JD, Thurston H. Salt intake and diuretic treatment of hypertension. Lancet 1979 ; ii: $21-2$.

199 Morgan T, Carney S, Wilson M. Interrelationship in humans between sodium intake and hypertension. Clin Exp Phar \& Physiol 1975; suppl 2: 127-9.

200 Morgan T. Effect of reduction in salt intake on hypertension. Am Heart J 1979; 97: $811-2$.

201 Morgan T, Gillies A, Morgan G, Adam W, Wilson M, Carney S. Hypertension treated by salt restriction. Lancet $1978 ; \mathrm{i}:$ : 227-30.

202 Parijs J, Joossens JV, Linden L van der, Verstreken $G_{3}$ Amery AK PC. Moderate sodium restriction and diuretics in the treatment of hypertension. Am Heart J $1973 ; 85: 22-34$.

203 Langford $H G$, Bilaufox D, Oberman A, et al. Dietary therapy slows the return of hypertension after stopping prolonged medication. JAMA 1985; 253:657-64.

Flamenbaum W, Cohen NS. The decision to "Unmedicate" (Editorial). JAMA $1985 ; 253: 687-8$.

204 Breedveld B, Blauw YH, Theunissen TJJM, Kouwenhoven T. Onderzoek naar de zoutgevoeligheid en de preferentie voor zoute smaken bij personen met normale en verhoogde bloeddruk. Voeding 1979; 40: 129-33.

205 Fodor $\mathrm{JG}$, Rusted IE. Epidemiological studies on hypertension in Newfoundlland. In: Kesteloot H, Joossens JV ed. Epidemiology of arterial blood 
pressure. The Hague/Boston/London: Martinus Nijhoff Publishers, 1980: 353-66.

206 Kromhout D, Bosschieter EB, Lezenne Coulander C de. Potassium, calcium, alcohol intake and blood pressure: the Zutphen Study. Am J Clin Nutr 1985; 41: 1299-1304.

207 Khaw KT, Thom S. Randomised double-blind cross-over trial of potassium on blood-pressure in normal subjects. Lancet 1982; ii: 1127-8.

208 Parfrey PS, Holly JMP, Wright $P$, Goodwin FJ, Vandenburg MJ, Evans SJW, Ledingham JM. Blood pressure and hormonal changes following alteration in dietary sodium and potassium in mild essential hypertension. Lancet 1981; $i$; 59-63.

209 Parfey PS, Wright P, Holly JMP, Evans SJW, Condon K, Vandenburg MJ, Goodwin FJ, Ledingham JM. Blood pressure and hormonal changes following alteration in dietary sodium and potassium in young men with and without a familial predisposition to hypertension. Lancet 1981; i: 113-7.

210 Parfrey PS, Ledingham JM, Goodwin FJ, Evans SJ, Vandenburg MJ, Holly JMP. Inaccuracies in two Lancet articles. Letter. Lancet 1981; ii: 31 .

21. Holly JPM, Evans SJW, Goodwin FJ, Vandenburg MJ, Leidingham JM. Reanalysis of data in two Lancet papers on the effect of dietary sodium and potassium on blood pressure. Lancet 1981; ii: 1384-6.

212 Skrabal $F$, Hörtnagl $H$, Auböck J. Low sodium/high potassium diet for prevention of hypertension: probable mechanisms of action. Lancet 1981; $\mathrm{ii}$ : 895-900.

213 Page LB, Vandewert D, Nader $K$, Lubin N, Page JR. Blood pressure of Quash Qai pastorall nomads in Iran in relation to culture, diet, and body form. In: Kesteloot H, Joossens JV ed. Epidemiology of arterial blood pressure. The Hague/Boston/London: Martinus Nijhoff Publishers, 1980: 401-20.

214 McCarron DA, Morris CD, Henry HJ, Stanton JL. Blood pressure and nutrient intake in the United States. Science 1984; 224: 1392-7.

215 Birkenhäger WH. Kationen in de voeding en hypertensie. Ned Tijdschr Geneeskd $1985 ; 129 ; 772-3$.

216 Johnson NE, Smith EL, Freudenheim JL. Effects on blood pressure of calcium supplementation of women. Am J Clin Nutr 1985; 42: 12-7.

217 Gleibermann L. Blood pressure and dietary salt in human populations. Ecology of Food and Nutrition 1973; 2: 143-56.

218 Prior IAM, Stanhope JM. Blood pressure patterns, salt use and rinigration in the Pacific In: Kesteloot H, Joossens IV ed. Epidemiology of arterial blood pressure. The Hague/Boston/London: Martinus Nijhoff Publishers, 1980: 243-62.

219 Oomen HAPC. Letter. Lancet 1980 ; ii: 260

220 Oomen HAPC. Nitrogen compounds and electrolytes in the urine of New Guinean sweet potato eaters - a study of normal walues. Trop Geogr Med 1967; 19: $31-47$.

221 Fregly MJ. Estimates of sodium and potassium intake. Annals of Internal Medicine. 1983; 98 (part 2): 792-9.

222 Doyle AE, Chwa KG, Duffy S. Urinary sodium, potassium and creatinine excretion in lyypertensive and normotensive Australians. Med J Aus 1976; 2: $898-900$.

223 Beevers DG, Hawthorne $\mathrm{WM}_{*}$ Padfield PL. Salt and blood pressure in Scotland. Br Med J 1980; $281: 641-2$. 
224. Komachi $\mathrm{X}$, Shimamoto " $T$ " Regional difference of blood pressure and its nutritional background in several Japamese populations. In: Kesteloot $H_{*}$ Joossens JV ed. Epidemiology of arterial blood pressure. The Haguef Bositon/London: Martinus Nijhoff Publishers, 1980: $379-94$.

225 Hofman $A$, Vaandrager GJ, Valkenburg. HA. Increased blood pressure in schoolchildren related to high sodium levels in drinking water. $J$ Epid Comm Health $1980 ; 34: 179-81$.

226 Breedveld BC. Onderzoek diëtistenopleiding "De Laan", den Haag, 1977. Persoonlijke mededeling.

227 KooluHulshof A. Een schatting vam het natrimgebruik van een groep jonge volwassenen in Renkum. Landbouwhogeschool Wageningen, 1981. Persoonlijke mededeling.

228 Egger $\mathrm{RJ}$, Zedde $\mathrm{A}$ van de. Effect van meervoudig onverzadigde vetzuren op de bloeddruk van matig hypertensieve en normotensieve mannen. Rapport $\mathrm{nr}$. $\mathrm{R}$ 6436, CIVO Toxicologie en Voeding TNO, Zeist, 1980.

229 Waard $H$ de Longitudinaal onderzoek. De invloed van de voeding met name van calcium en fosfatopname op de calcium- en botstofwisseling van gezonde vrouwen in de menopauze (voorlopige titel), 1980. Persoonlijke mededeling.

230 Daenen Ch, Stubenauch A. Diëten bij bejaarden. Rapport Landbouwhogeschool Wageningen, 1983.

231 Rookus MA. Pleij LMH, Beek EJ van der, Hulshof KFAM, Weerd H van de, Schrijver J, Luyken R. Vergelijkend onderzoek nat de voedingstoestand en het fysiek prestatievermogen wan 18-30 jarige lacto-ovo wegetariêrs en omnivoren. Voeding $1983 ; 44: 246-55$.

232 Erwteman TM. Zoutarm dieet, diuretica en beta-blokkade voor de behandeling van lichte tot matig ernstige hypertensie. Academisch Proefschrift, Amsterdam, 1982.

233 Vaessen HAMG, Kamp CG van de. De natrium-, kalium- en keukenzoutopneming van Nederlanders per etmaal; een onderzoek op basis van duplicaten van 24-uurs voeding. Voeding 1985; 46: $102-4$.

234 Maas J, Hofman A. Hoge bloeddruk bij jonge volwassenen: de kans op het vinden van verhoogde bloeddrukwaarden en daarvoor voorspellende factoren. Ned Tijdschr Geneeskd 1984; 128: 150-3.

235 Birkenhäger WH. Praktische aspecten van het opsporen van thypertensie bij jonge volwassenen. Ned Tijdschr Geneeskd 1984; 128: 172-3.

236 Berenson GS, Voors A W, Webber LS. Importance of blood pressures in children. In: Kesteloot $\mathrm{H}_{3}$, Joossens JV ad Epidemiology of arterial blood pressure. The Hague/Boston/London: Martimus Nijhoff Publishers, 1980: $71-97$.

237 Centraal Bureau voor de Statistiek. Statistisch zakboek 1981. 's-Gravenhage: Stantsuitgeverij, 1982.

238 CIVO Toxicologie en Voeding TNO. Rapport: Indeling naar welstandklasse. Zeist.

239 Weiner JS, Lourie JA. Human Blology. A guide to field methods. Blackwell Scientific Publications. Oxford and Edinburgh.

240 Baccke JAH. Determinants of body fatness in young adults living in a Dutch community. Acadlemisch Proefschrift, Wageningen, 1982.

241. Kromhout D. Zijn veranderingen in de voedingstoestand beïnloed door snackgebruik? Voeding 1980; 41: 40-4.

242 Eijk JThM van, Gubbels JW. Wetenschappelijk onderzoek in de huisartsgeneeskunde. $1^{\circ} \mathrm{ed}$. Utrecht. Nederlands Huisartsen Genootschap, 1983. 
243 Draper NR, Smith H. Applied Regression Analysis 2e ed. New York: John Wiley \& Sons, 1981.

244 Gewstat Mannual Numerical Algerithms Group Limited, Oxford, 1980.

245 Snedecor GW, Chochran WG. Statistical methods. 6e ed. Ames, lowa: The lowa State University Press, 1967.

246 Swinscow TDV. Elementaire statistiek. In: Waard F de, red. De Nedierlandse Bibliotheek der Geneeskunde, deel 142. Alphen aan den Rijn/Brussel: Stafleu, 1981.

247 Prims A. Mensen met werhoogde bloeddruk en hun bereidheid deze te laten controleren; een bevolkingsonderzoek in Krimpen aan de IJssel, witgaande van het gezondheidscentrum aldaar. Ned Tijdschr Geneeskd 1980; 124: 723-6.

248 Centraal Bureau voor de Statistiek/ Ministerie van Volksgezondheid en Millieuhygiëne. Compendium gezondheidsstatistiek Nederland 197.4. "s-Gravenhage: Staatsuitgeverij, 1974.

249 Centraal Bureau voor de Statistiek. Statistisch zakboek 1982. "s-Gravenhage: Staatsuitgewerij, 1982 .

250 Vandenbroucke JP, Matroos AW, Heide-Wessel C van der, Heide RM van der. De Quetelet-index als voorspeller van de levensverwachting op middelbare leeftijd; herbeoordeling na 25 jaar bij 3091 personen. Ned Tijdschr Geneeskd 1982; 126: 2180-4.

251 Hermus RJJ. Overvoeding, overgewicht, vroegtijdige sterfte Ned Tijdschr Geneeskd 1983; 127: 787-9.

252 Kok $F$, Matroos AW, Vandenbroucke JP. Te zwaar of niet te zwaar. Een onderzoek bij de volwassen bevollking van Nederlland. Voeding 1981; 42: 262-9.

253 Luyken R, Luyken-Koning, FWM, Thissen JTNM, Wijn JF de. Somatometrische gegevens van geselecteerde groepen Nederlandse adolescenten en jonge volwassenen van 12 tot 25 jaar (1970-1980). Voeding 1986; 47: 24-32.

254 Kromhout $D$, Drijver M. Zijn voedingsaanbevelingen in de praktijk te realiseren? In: Kroes R, Claesen H, Hermus RJJ, Kroonenberg CC, Damme J wan, Ree JW van, red. Voeding in de praktijk. Utrecht: Bohn, Scheltema \& Holkema, 1984; IV-B2 1-11.

255 sicking PJM, Hermus RJJ, Matroos AW. Opsporing verhoogde bloeddruk door leken. MC 1981; 36: $881-4$.

256 Rumke Chr L. De teruggang (= regressie) naar thet gemiddelde. Ned Tijdschr Geneeskd 1984; 128: 158-60.

257 Gezondheidsraad. Advies maximal toelaatbare concentratie natrium in drinkwater. "s-Gravenhage: Staatsuitgeverij, 1980.

258 Kesteloot H, Vuylsteke M. Costenoble A. Relationship between blood pressure and sodium and potassium intake in a Belgian male population group. In: Kesteloot H, Joossens JV ed. Epidemiology of arterial blood pressure. The Hague/Boston/London: Martinus Nijhoff Publishers, 1980: 345-51.

259 Armstrong B, Phil D, Clarke H, Martin C, Ward W, Norman N, Masarei J Urinary sodium and blood pressure in vegetarians. Am J Clin Nutr 1979; 32 : $2472-6$.

260 Ministerie van Welzijn, Volksgezondheid en Cultuur. Nata Voedingsbeleid. 'sGravenhage: Staatsuitgeverij, 1983.

261 UCV-tabel, uitgebreide voedingsmiddelentabel. "s-Graverhage: Voorlichtingsbureau voor de Voeding, 1984.

262 World Health Organization. Estimation of sodium intake and output: Review of 
methods and recommendations for epidemiological studies. Report on a WHO meeting. Gothenburg, Sweden 1983.

263 Henningsen $N$, Larsson $L$. Nilson $D$. Is the preservation of the natural potassium/sodium-ratio in our industrial and home-prepared food possible? In: Berg EME van den, Bosman W, Breedveld BC, red. Nutrition in Europe. Proceedings of the 4th European Nutrition Conference. The Hague; Voorlichtingsbureau voor de Voeding 1985: 247.

264 Epstein FH. How useful is a family history of hypertension as predictor of future hypertension? Annals of Clinical Research 1984; 16 suppl: 32-4.

265 Natriumbeperkt- energie (= calorieèn)-beperkt dieet. Dieetbrochures nummer $319,320,325$ en 326. 's-Gravenhage: Voorlichtingsbureau voor de Voeding, 1984.

266 Kaplan NM. Non-drug treatment of hypertension. Annals of Internal Medicine $1985 ; 102: 359-73$.

267 Kempner W. Treatment of hypertensive vascular disease with rice diet. Am J Med 1948; 545-77.

268 Crebolder HFJM. Voedingsvoorschriften in de huisartsenpraktijk. Voeding 1979; 40: 314-9.

269 Saris WHM. "Prognose van het vermageren op lange termijn". Vergelijking van verschillende therapievormen. TGO 1983; 8: 2075-9.

270 Ree JW van, Gerwen W wan, Hoogen $H$ van den. Interventie bij een verhoogd risico op hart-en vaatziekten. 1. Resultaten op langere termijn van interventie bij hypercholesterolemie, adipositas en roken. Huisarts en Wetenschap 1985; 28 : $21-4$.

271 Amery A, Birkenhäger W, Brixko P, et al. Moriality and morbidity results from the European Working Party on High blood pressure in the Elderly trial. Lancet 1985; i: 1349-54.

272 Geerling J. Hypertensie bij bejaarden. Ned Tijdschr Geneeskd 1985; 129: 2340-1.

273 Wilson JMG, Jungner G. Principles and practice of screening for disease. Public Health Papers, World Health Organization. Geneva, 1968.

274 Beard, TC, Cooke HM, Gray WR, Ellem DP. Spontaneous remission and its significance for trials in primary prevention of hypertension. Annals of Clinical Research 1984; 16 suppl 43: 132-5.

275 Bulpitt CJ, Daymond M, Bulpitt PF, et al. Is low salt dietary advice a useful therapy in hypertensive patients with poorly controlled blood pressure? Annals of Clinical Research 1984; 16 suppl 43: 143-9.

276 Tuomilehto J, Puska P, Nissinen A, et al. Community-based prevention of hypertension in North Karelia, Finland. Annals of Clinical Research 1984; 16 suppl 43: 18-27.

277 Pietinen P, Tanskanen A, Nissinen A, Tuomilehto J, Puska P. Changes in dietary habits and knowledge concerning salt during a community-based prevention programme for hypertension. Annals of Clinical Research 1984; 16 suppl 43: $150-5$.

278 Bruce $\AA$. Sodium in nutrition policy. Annals of Clinical Research 1984; 16 suppl 43: 174-8.

279 Olshansky SJ. Pursuing Longevity: Delay vs Elimination of Degenerative Diseases. AJPH 1985; 754-6.

280 Black DG, Heagerty AM, Bing RF, Thurston H, Swales JD. Effects of treatment for hypertension on cerebral haemorrhage and infarction. Br Med J 1984; 289: 156-9.

281 Keuning R. Towards healthful diets: the role of food industry. In: Berg EME van 
den, Bosman W, Breedveld BC, red. Nutrition in Europe. Proceedings of the 4th European Nutrition Conference. The Hague; Voorlichtingsbureau voor de Voeding 1985: 49-62.

282 Pangborn RM, Pecore SD. Taste perception of sodium chloride in relation to dietary intake of salt. Am J Clin Nutr 1982; 35:510-20.

283 Pietinen $\mathrm{P}$, Ruotsalainen $\mathrm{P}$, Tanskanen A. Puska $\mathrm{P}$. Sodium intake reduction in volunteer families bij using a salt substitute and mutrition couselling. Ann Nutr Metab 1981; 25: 371-80.

284 Altschul AM, McPherson R, Burris JF. Dietary sodium, the ratio Nat/K+ and essential hypertension. Nutr Abstr Rev 1984; 54: 823-44.

285 Compendium dieetpreparaten en voedingsmiddelen $13 \mathrm{e}$ ed. Haarlem: De Toorts, 1985.

286 Dis SJ wan. Eten uit de muur, snacks en frituren. In: Kroes R, Claesen $\mathrm{H}$, Hermus RJJ, Kroonenberg CC, Damme J van, Ree JW van, red. Voeding in de praktijk. Utrecht: Bohn, Scheltema \& Holkema, 1984; VII-D3 1-9.

287 Kromhout D. Is de huidige voeding een prudente voeding? Voeding 1980; 41 : $255-8$.

288 Cramwinckel AB. Algemene voedingswoorlichting. In: Kroes $\mathrm{R}$, Claesen $\mathrm{H}$, Hermus RJJ, Kroonenberg CC, Damme J van, Ree JW van, red. Voeding in de praktijk. Utrecht: Bohn, Scheltema \& Holkema, 1984; IV-B3 1-7.

289 World Health Organization. Primary prevention of coronary heart disease. Report on a WHO meeting. Copenhagen, 1985.

290 Hartog C den, Hautvast JGAJ, Hartog AP den. Nieuwe Voedingsleer. Utrecht/Antwerpen, Het spectrum, 1978.

291 World Health Organization. Gross F, Pisa Z, Strasser T, et al. Management of arterial hypertension - a practical guide for the physician and allied health workers. Geneva, 1984. 

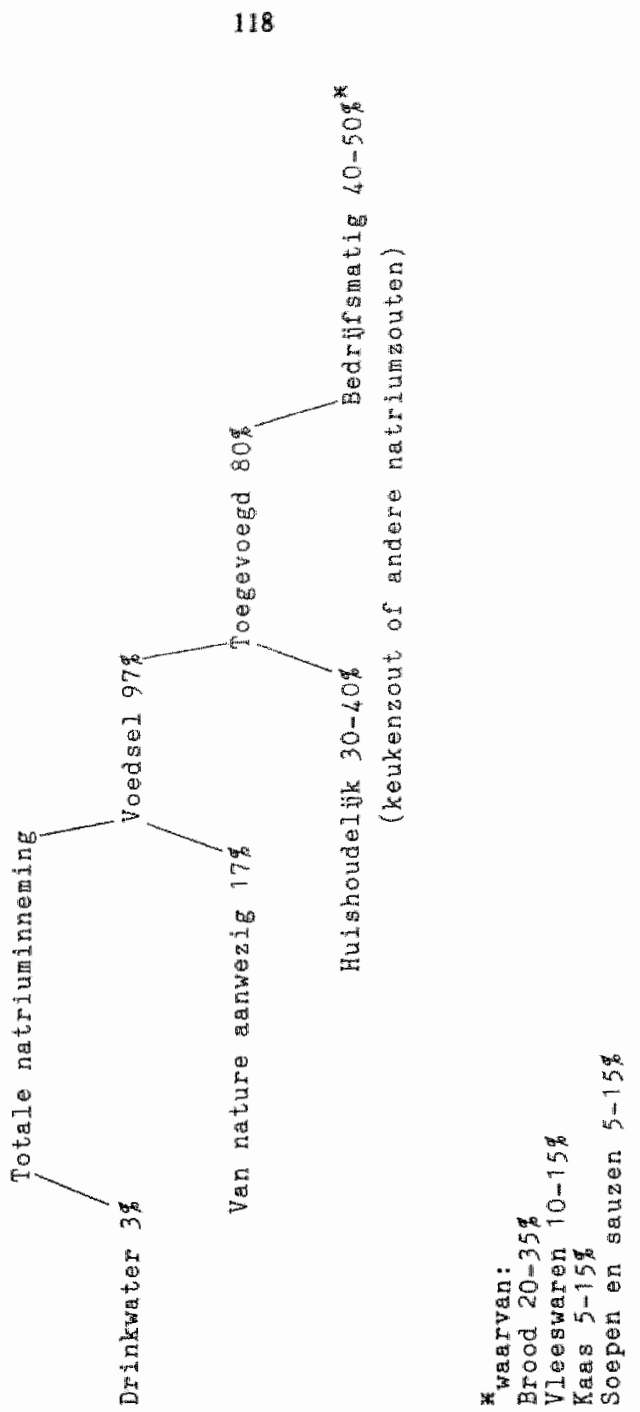


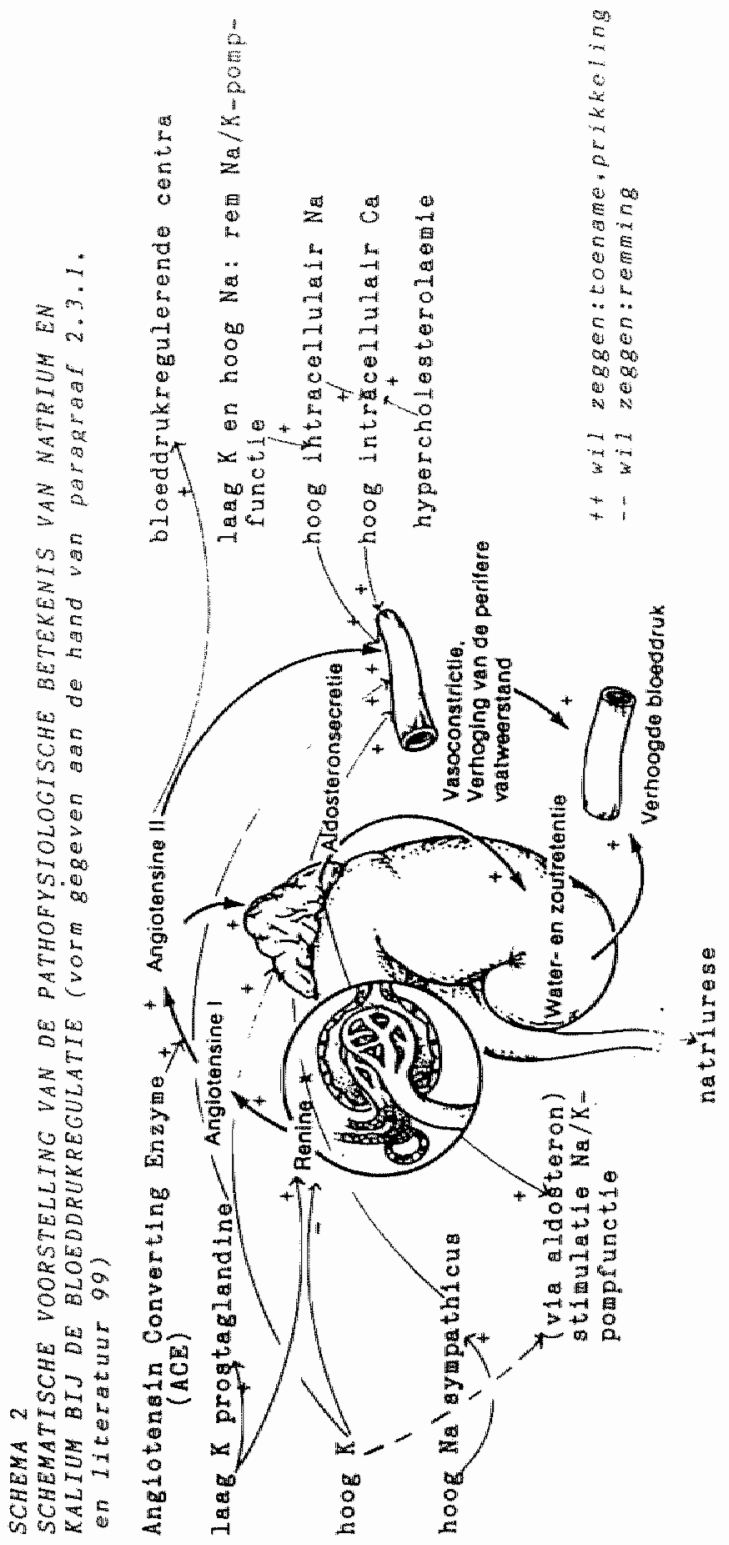




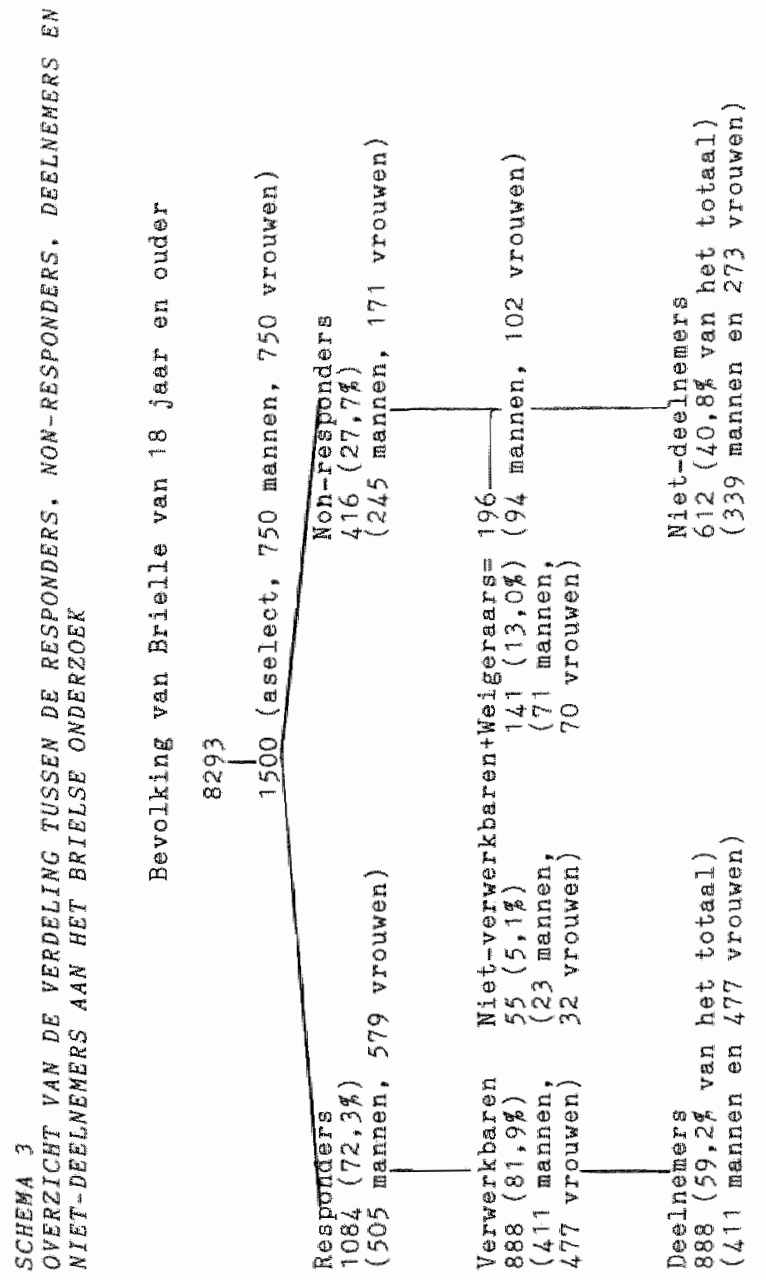




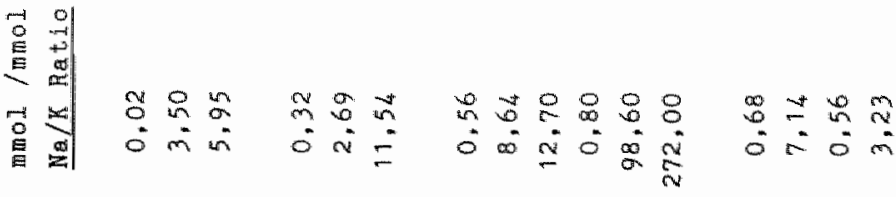

5

tas

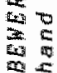

$\lim _{0}$

点

is

$\mathrm{L}^{2}$

$i_{-\infty}$

tion

然

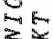

$\sum_{0}$

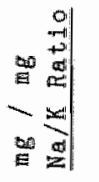

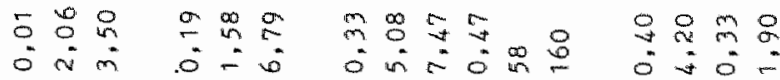

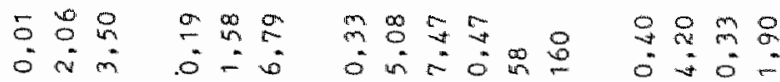

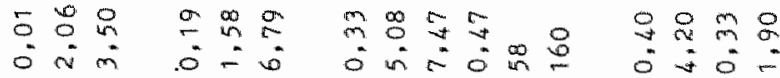

$\begin{array}{lll}0 & 0 \\ 0 & 8 \\ 0 & 8 & 8 \\ 0 & 0 & 8 \\ 0 & 2 & 0\end{array}$

$$
8
$$

$\geq 0$

$\leq$

오네

trits

act

3

40

$\frac{1}{6}$

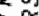

$\$ 8$

$\rightarrow$

$E$

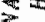

Lex

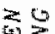

2

Ex

an

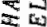

wis

$x$

3

xit

世

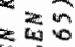

40

100

$\geq 0$

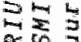

or

$\rightarrow-\infty$

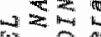

40

\&ing

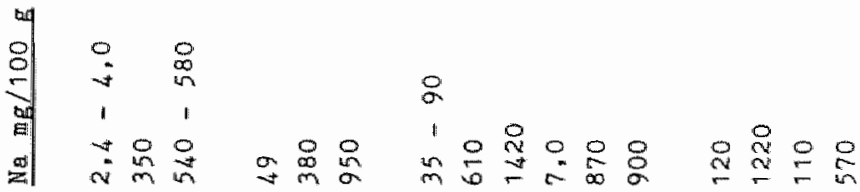

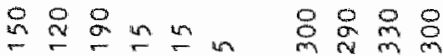

60
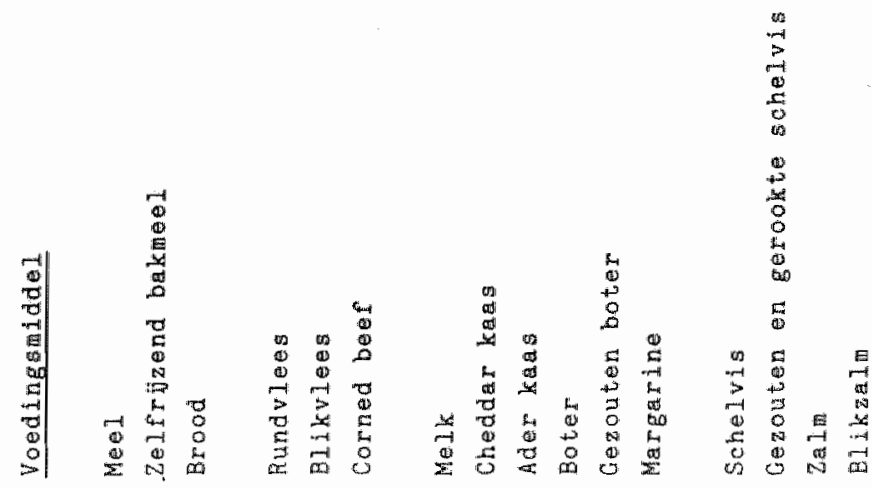


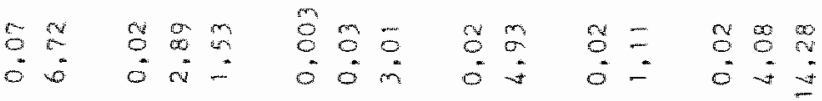

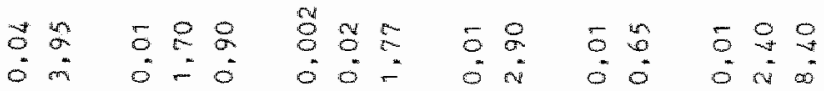

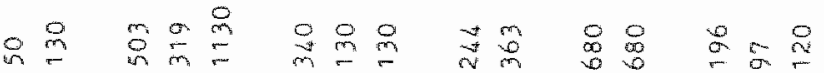

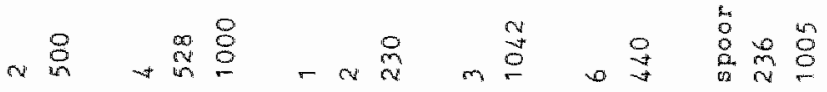

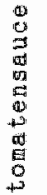

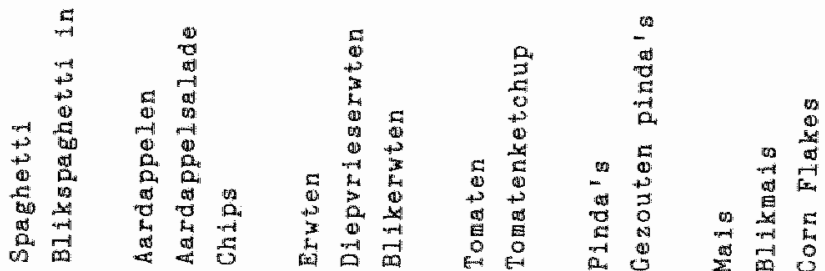


का

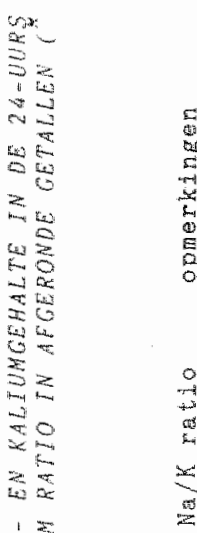

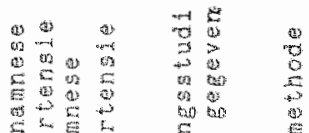

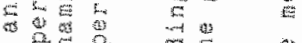

$0 \sum_{0} b_{0} \quad a_{0}$

7.

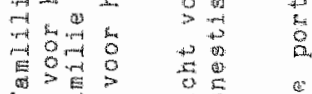

诰

a

范

$\$$

$\pm \sum^{2}$

or

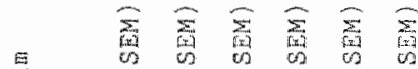

$\sum_{i=1}$

$>\sum_{0}$

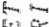

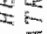

a. $z$

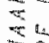

2

is

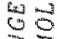

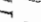

24

$6 \frac{1}{6}$

Q

in

$2 \sum_{0}^{\infty}$

$i_{i=1}^{\infty} m_{n}^{\infty}$

난

so

$2 \mathrm{x}$

xᄄ

$\sum_{0}^{2}$

$t_{i=1}$

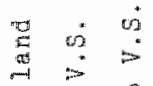

0
+4
0

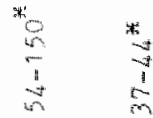

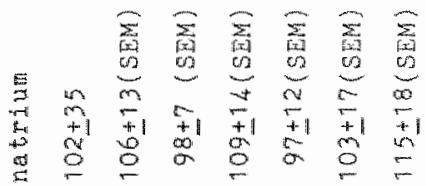

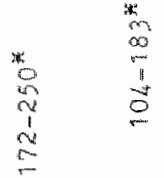

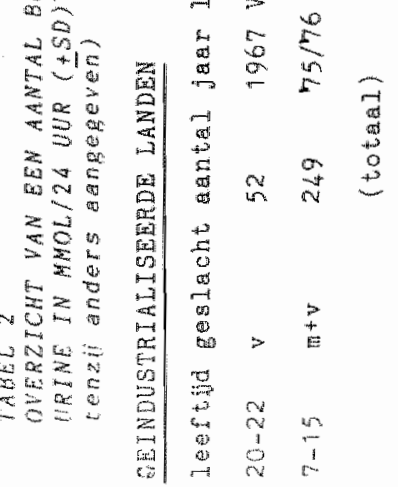

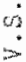

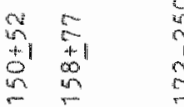

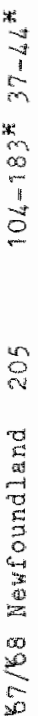

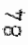

$\bar{s}$

$\frac{a}{2}$

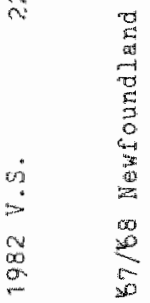

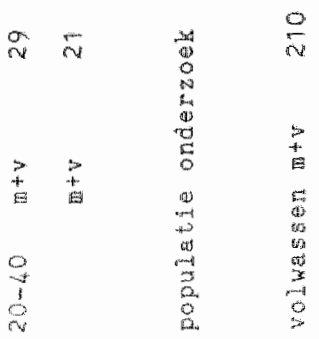


i

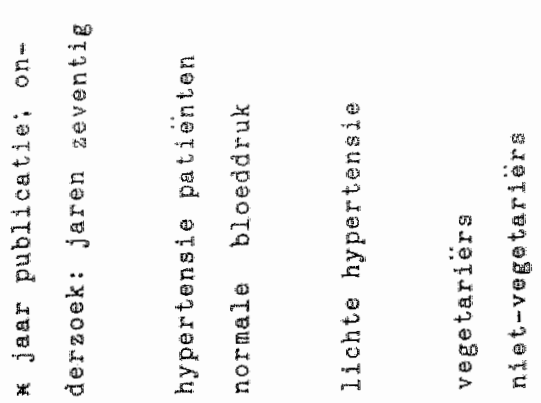

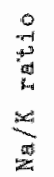

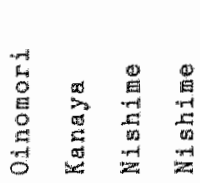

$m_{i}+1+\infty$

$\stackrel{m}{m}$

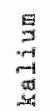

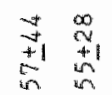

$\begin{array}{ll}\infty & 0 \\ 0 & 0 \\ +1 & +4 \\ 0 & 4 \\ 0 & 4\end{array}$

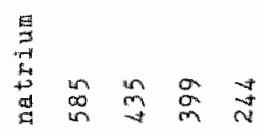

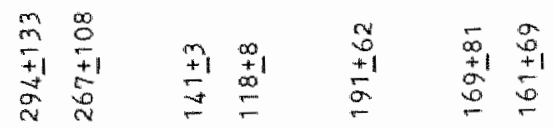

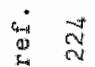

5

8

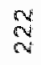

$8 \quad \infty$

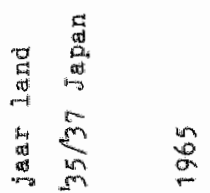

$\sum_{\substack{\infty \\ \operatorname{lat}_{0}}}$

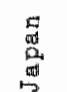

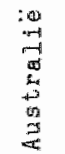

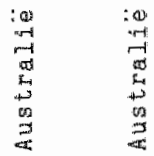

o

$\begin{array}{ll}0 & 0 \\ 0 & 0 \\ 0 & 0\end{array}$

$\infty$

50

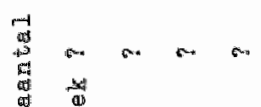

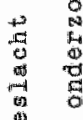

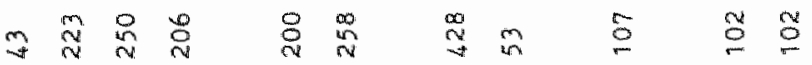

and

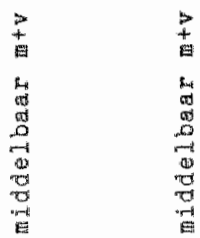

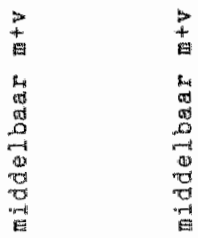

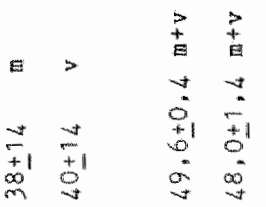

势

i

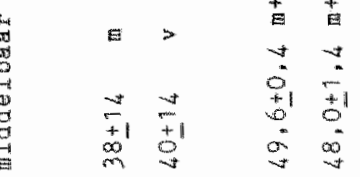

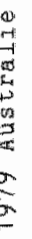



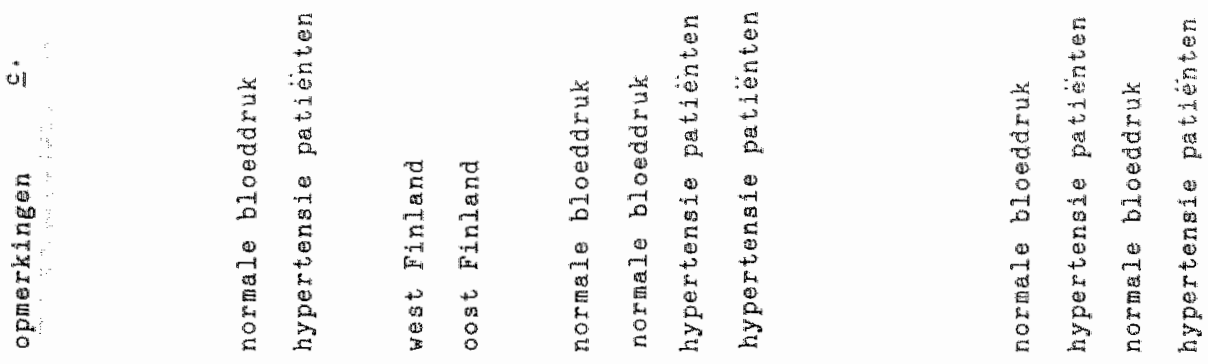

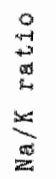

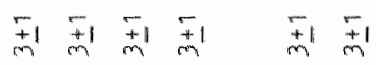

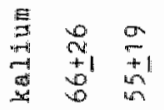

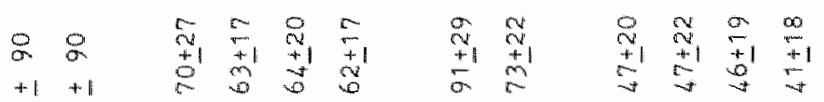

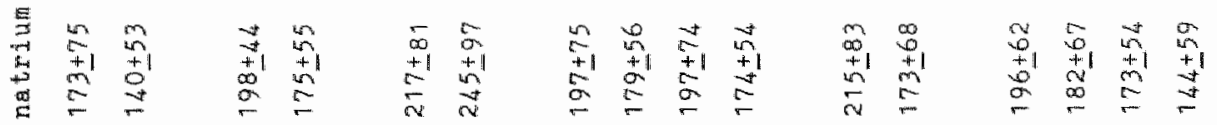

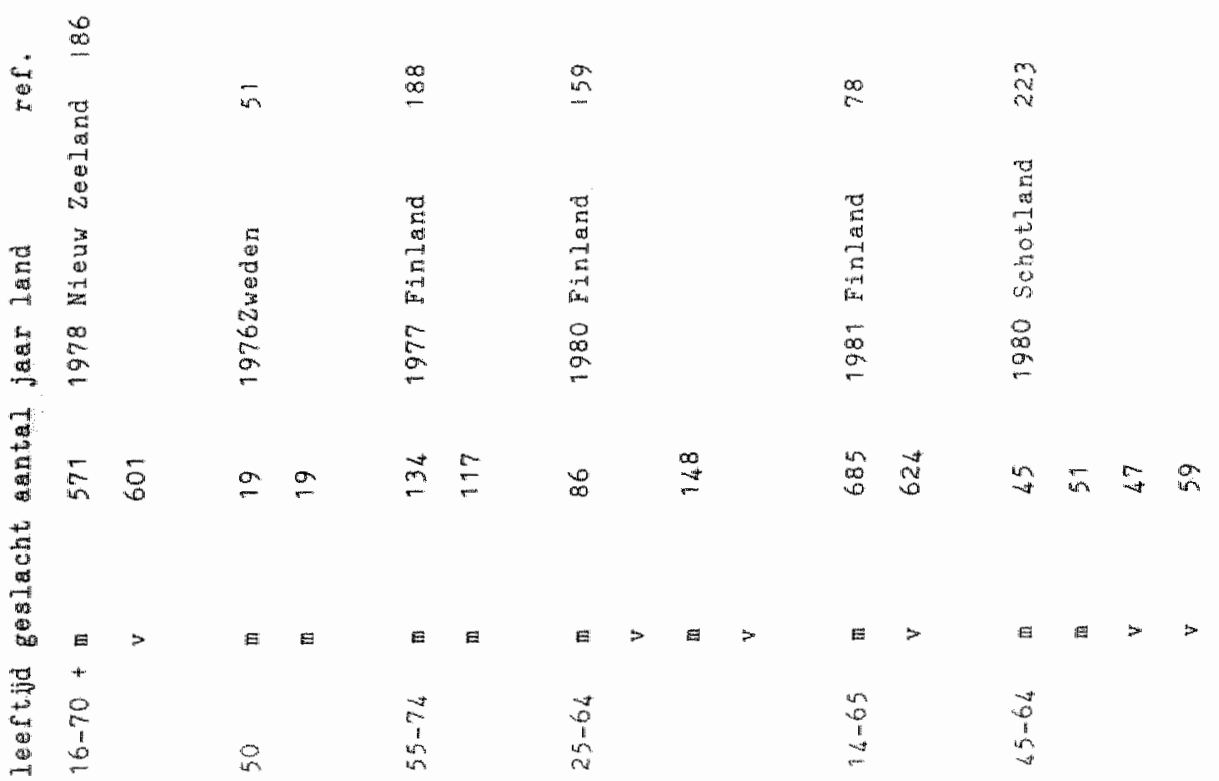



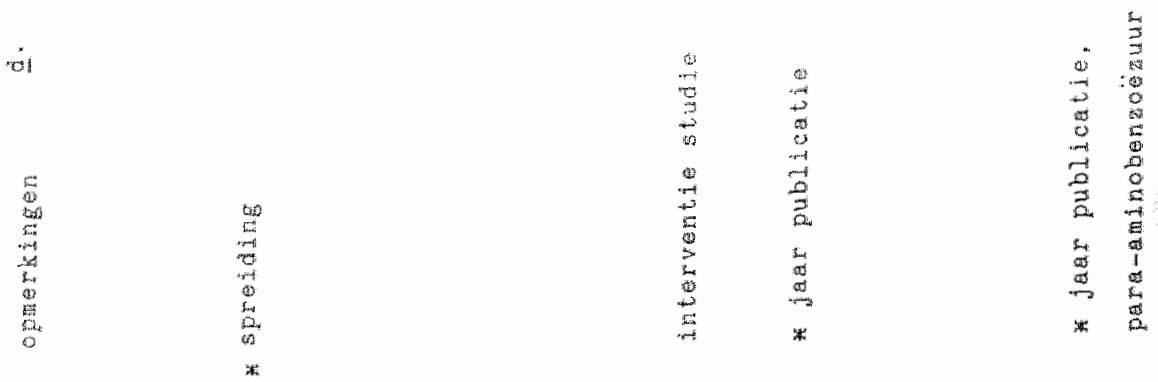

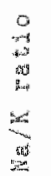
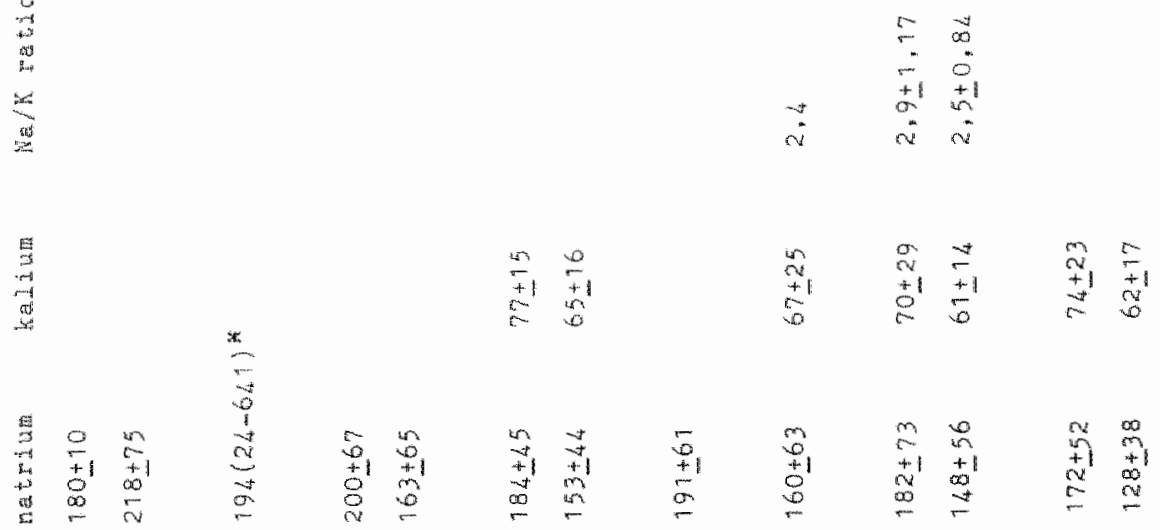

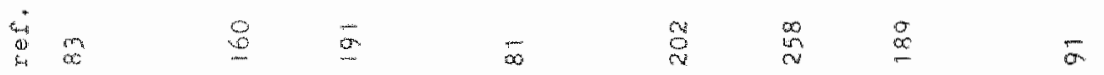

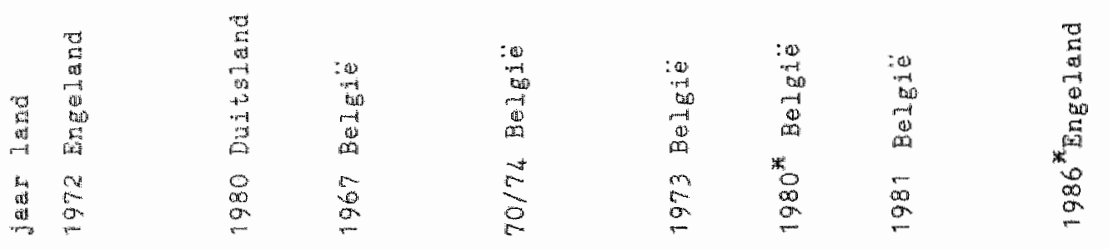

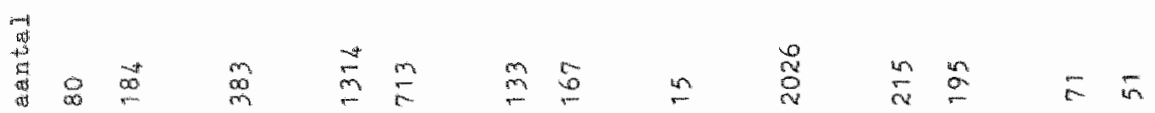

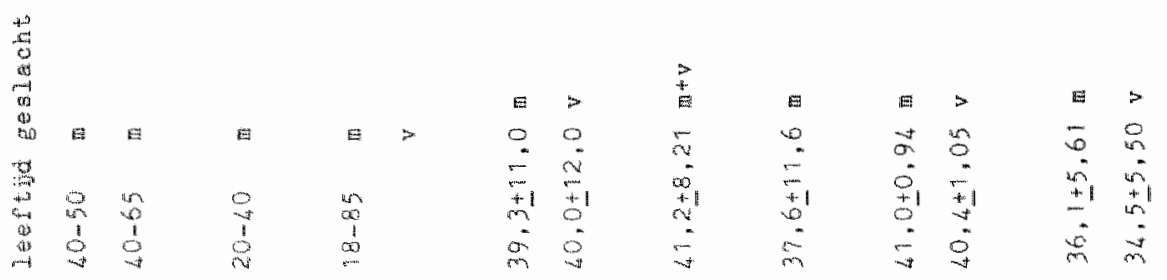



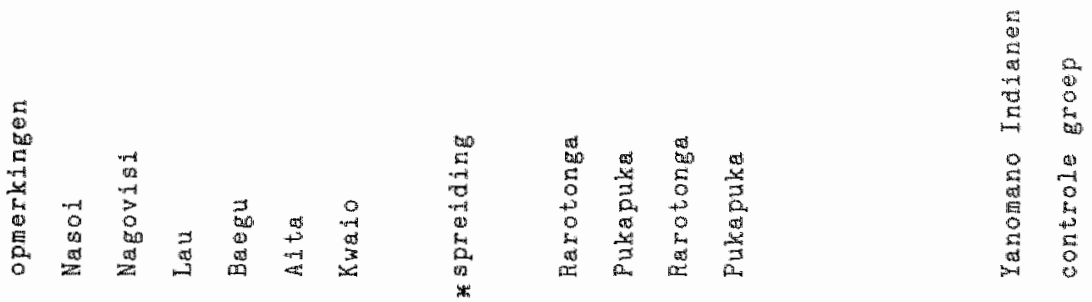

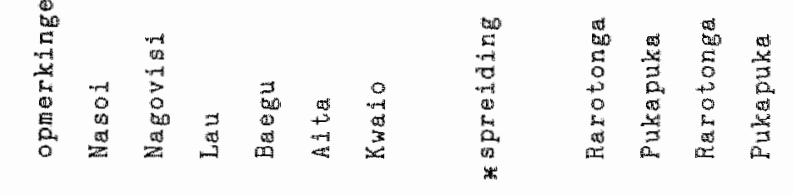

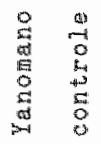

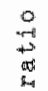

$\sum_{2}^{x}$

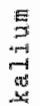

$*$
8
0
1
1
2
2
0

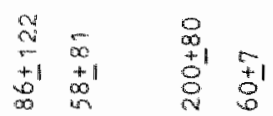

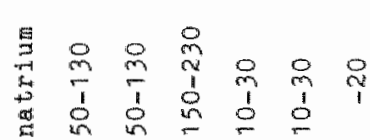

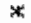

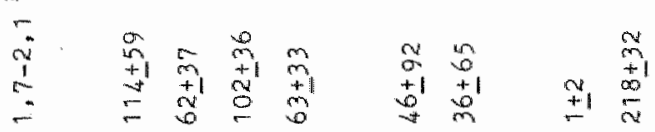

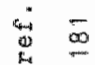

8

$\frac{\infty}{\alpha} \quad \infty$

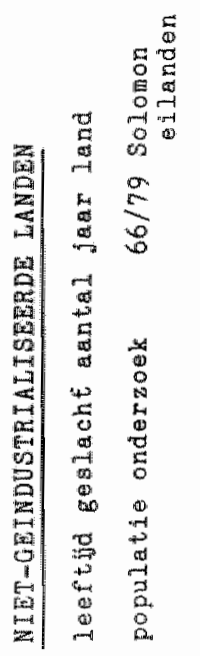

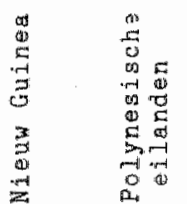

50

$\infty$

6

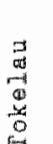

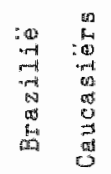

$\sum^{\infty}$

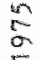

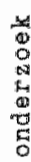

$m m_{m}^{\infty} \stackrel{m}{m}$

뭉

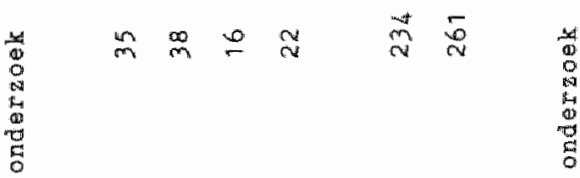

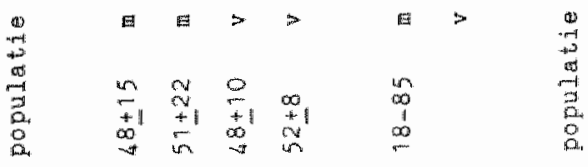


$\Leftrightarrow$

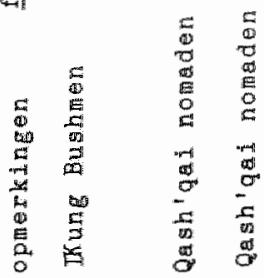

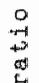

$\sum_{\infty}^{\infty}+\infty$

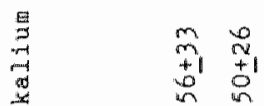

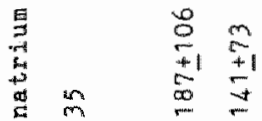

$\sum_{a}^{\infty} 5 \frac{m}{2}$

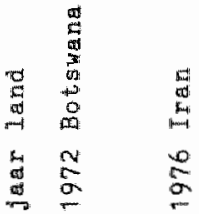

离

a

0
0
0
-1
0

且

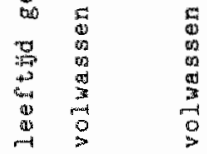




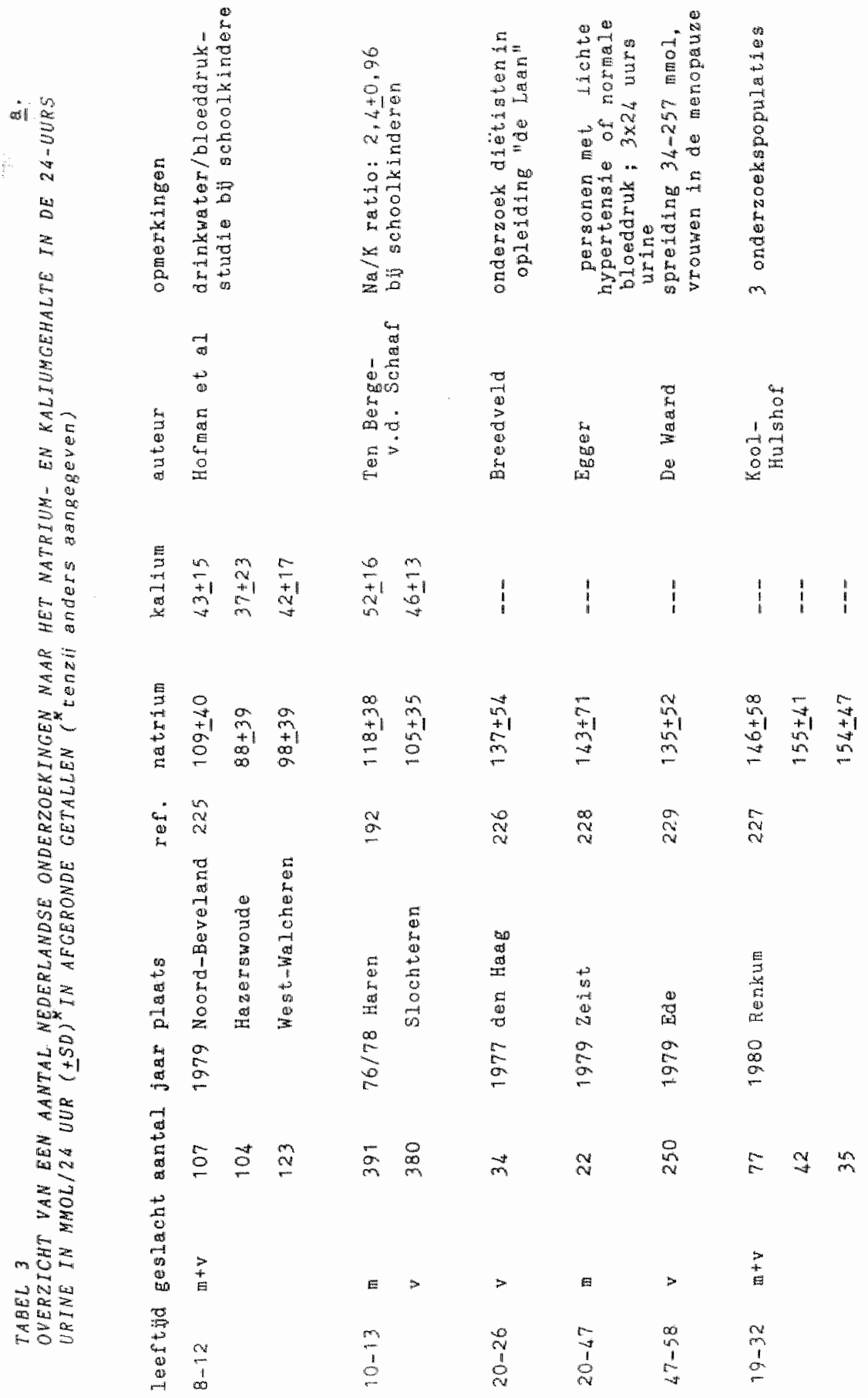



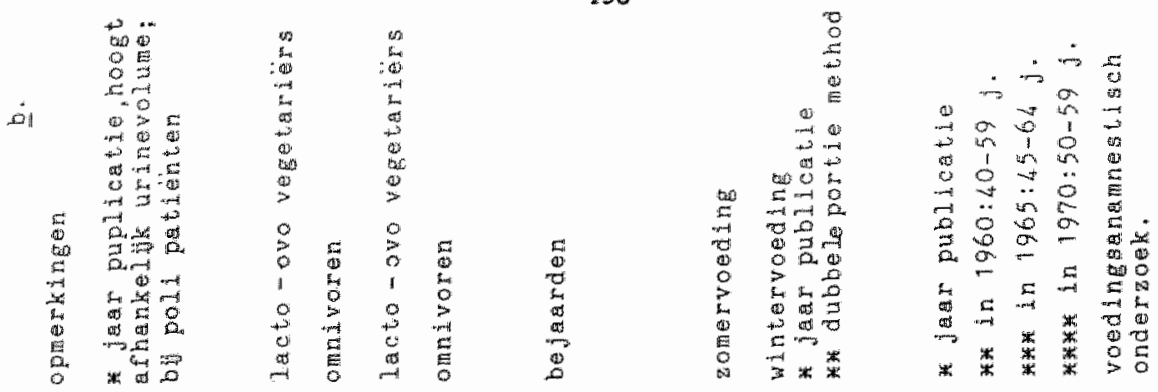

\begin{tabular}{|c|c|c|}
\hline & $\overbrace{\mathbb{d}}^{-1}$ & ") \\
\hline$E^{2}$ & 0 & कै \\
\hline 迹 & $\begin{array}{l}n \\
\frac{n}{3} \\
0 \\
0 \\
8 \\
0\end{array}$ & 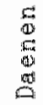 \\
\hline
\end{tabular}

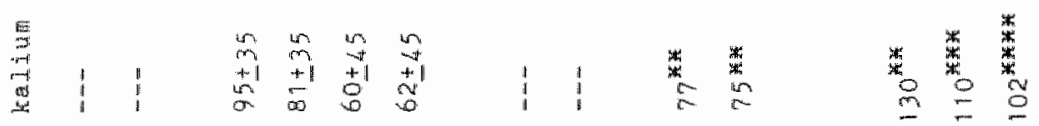

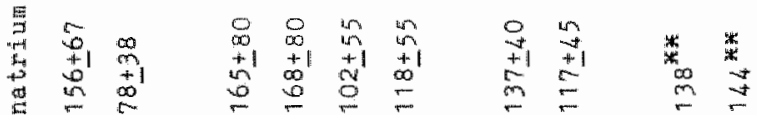

in

$\sqrt{n}$

$\infty_{\substack{n \\ n}}$

$\stackrel{m}{m}$

8

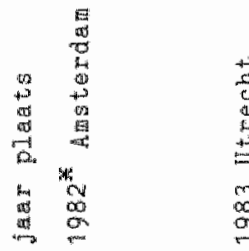

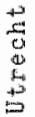

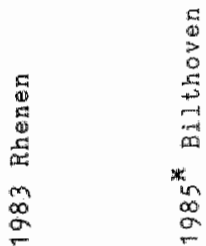

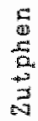

$\stackrel{\infty}{\infty}$

$\underset{\sigma}{\infty}$

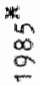

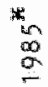

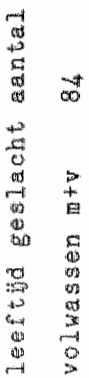

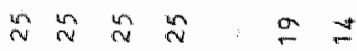

85

$\infty$
100
0

현

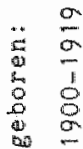




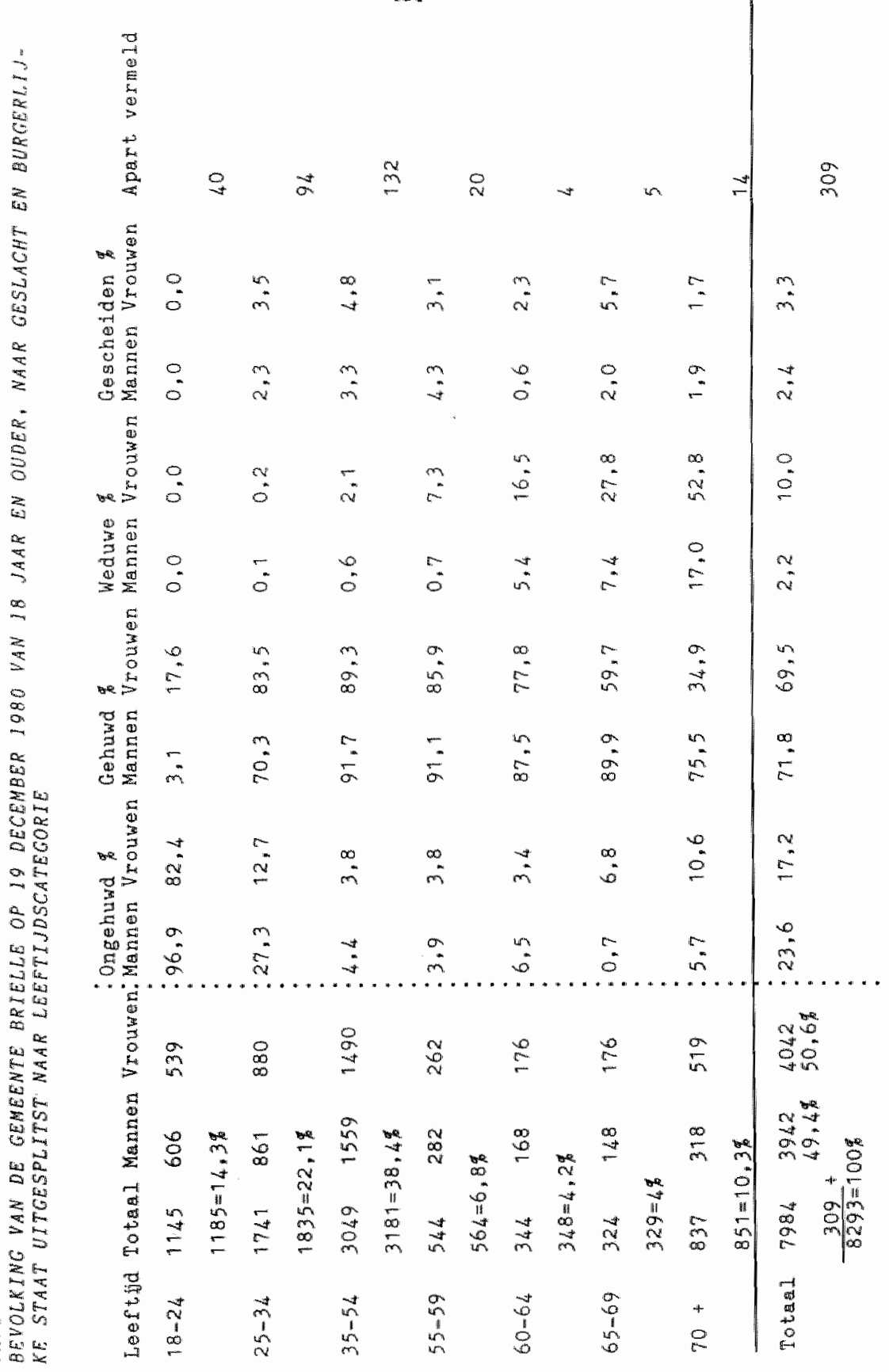




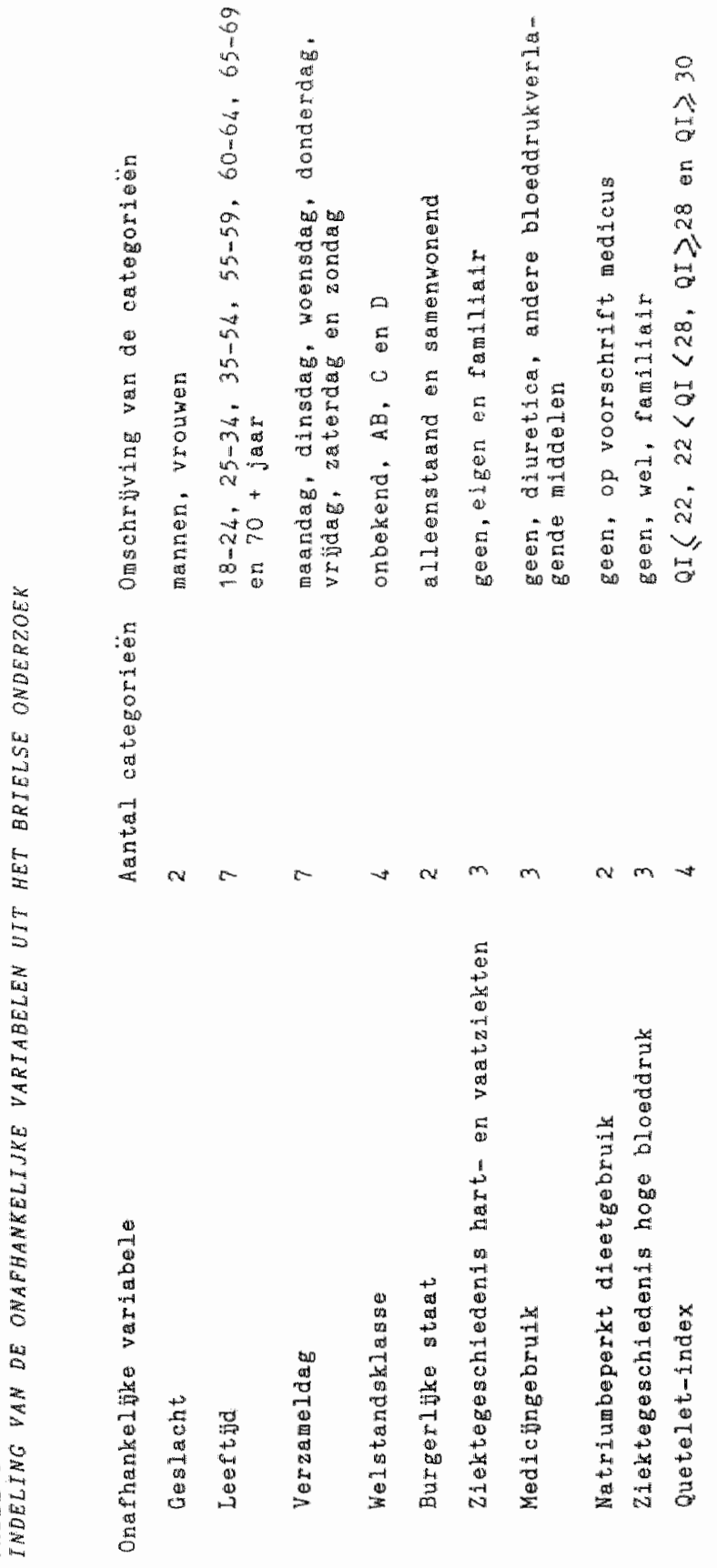




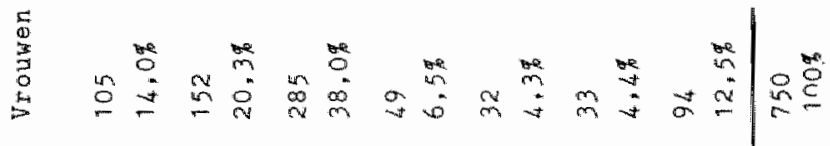
E 


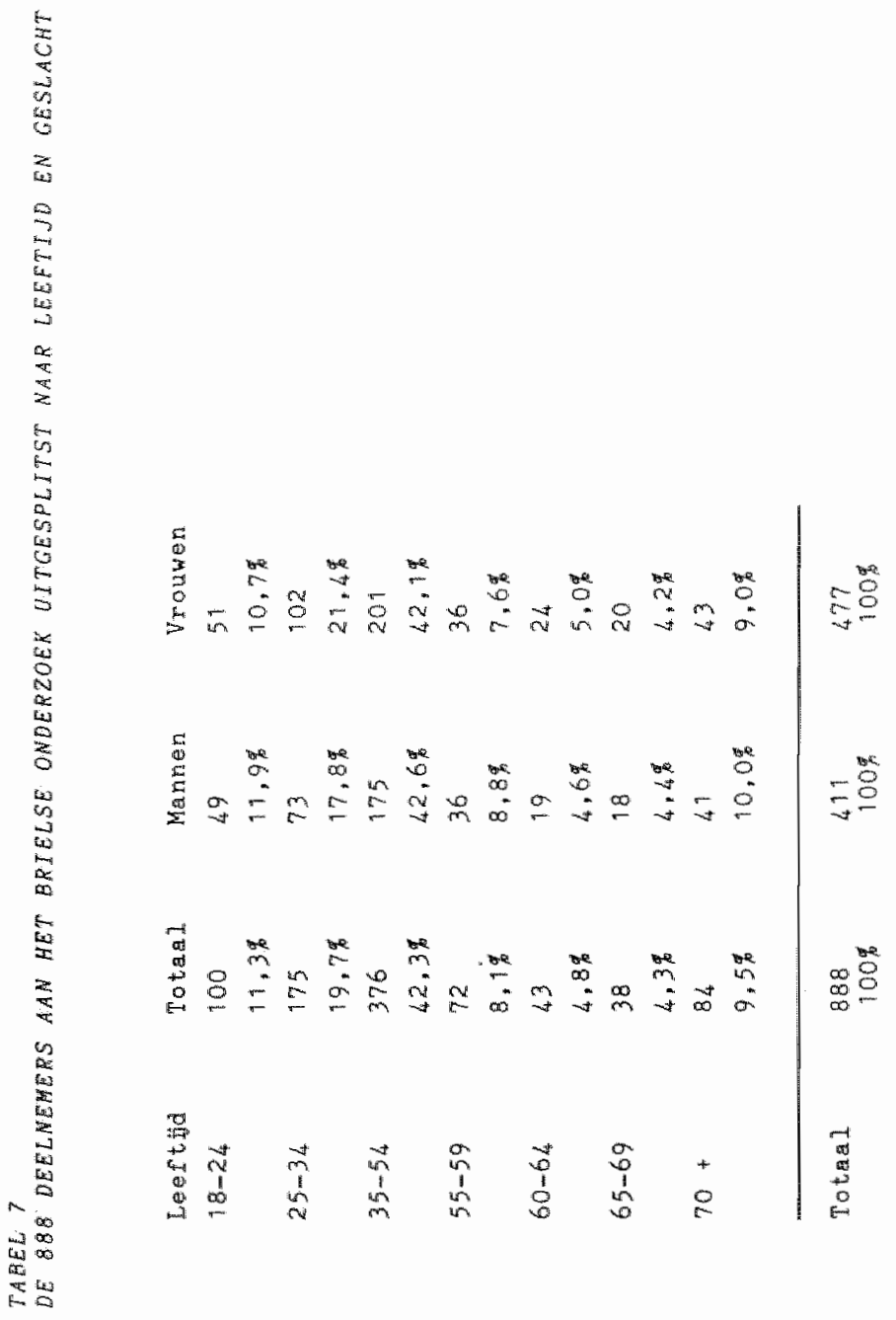



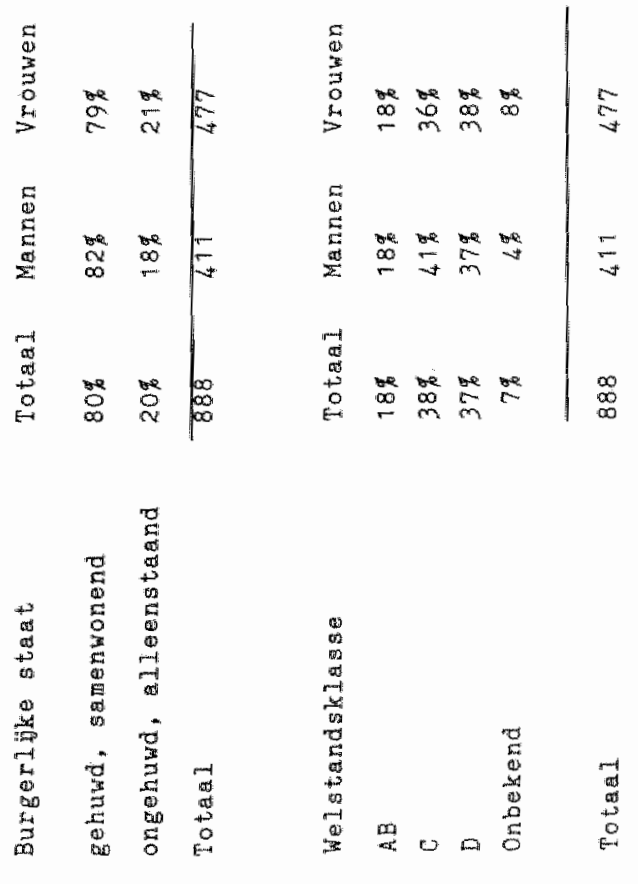
要

to

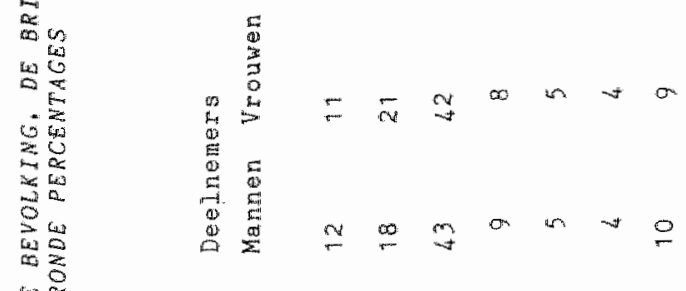

tor

整

mite

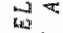

o.

(n)

it

용

$\geq 0$

$\leq 2$

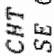

in

wis

by

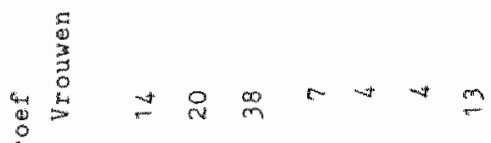

究

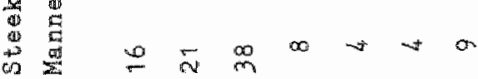

tol th

$\infty$

$\sum_{i \rightarrow}$

ix

bet

4

tris

位

co

in

겅

co

at

5

$\infty$

tus 0

tio

$a x$

th

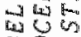

a 0

T.
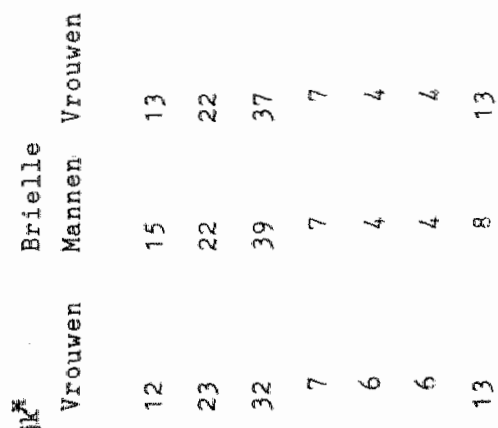

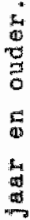

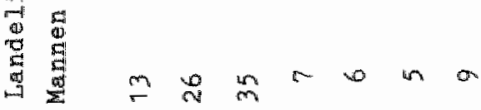

웅

9
9
4
9
9
9

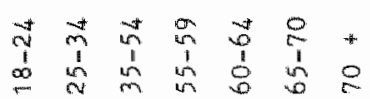

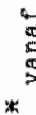


$\infty$

$\stackrel{\infty}{a}$

$\underset{5}{5}$

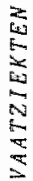

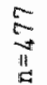

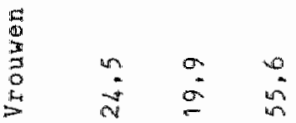

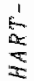

这

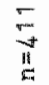

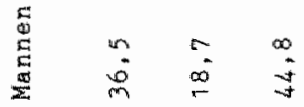

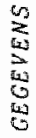

要

w

讨

a

$\infty$

0

$\geq \infty$

$\leq$ thet

$\sum_{\infty}^{\infty}$

It

约

ot

$\stackrel{\operatorname{lng}}{=}$

is on

05

$\sum x$

is

क

不战战

$\begin{array}{lll}0 & * & 0 \\ 0 & 0 & 0\end{array}$

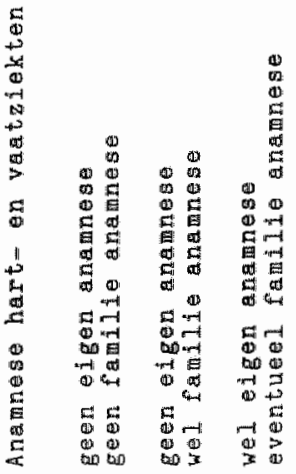




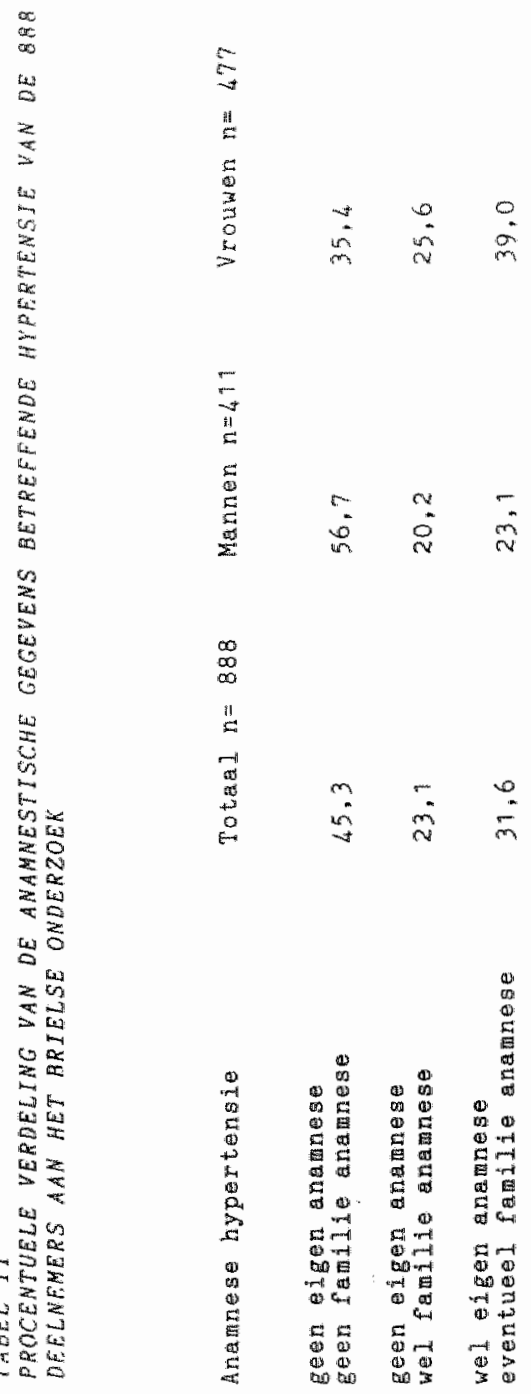




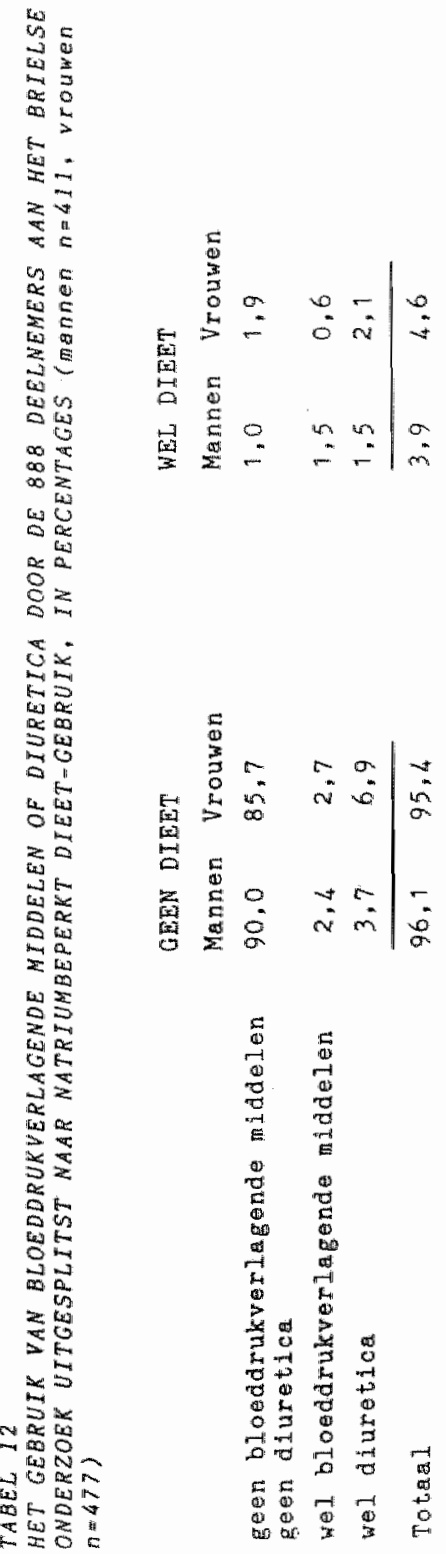




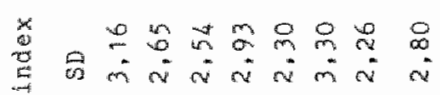
is $\frac{b}{4}$

कृ

tom $a=0$ in 0 \%

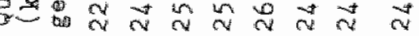

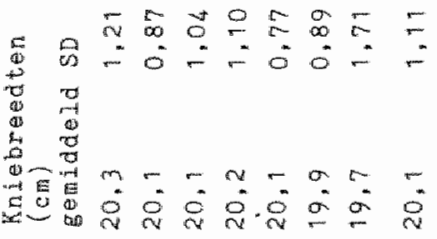

남

紊

wh

(4)

5

th

$4 \mathrm{cos}$

tin

단

Un

and

is

5

$\operatorname{lom}_{\rightarrow \rightarrow \infty}$

is

is

$x$

$x_{0}^{+}$

넝

$\lim _{0 \rightarrow 2}$

$\Rightarrow x$

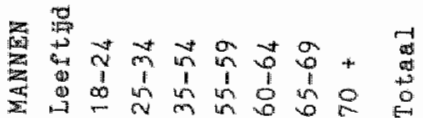

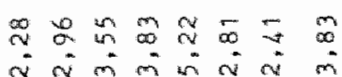

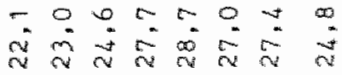

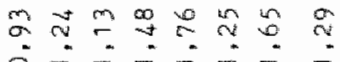

$\begin{array}{lllll}\infty & \infty & m & m & 0 \\ \infty & \infty & 0 & 0 & 0\end{array}$

in 8 wn un 50 in

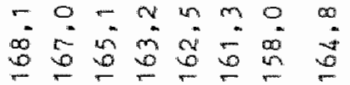

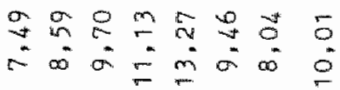

$\begin{array}{lllll}0 & 0 & 0 & m & 0 \\ 0 & 0 & 0 & 0 & 0\end{array}$

要

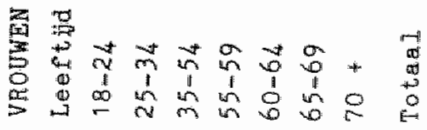


ton

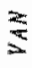

ב

$\mathbb{2}_{2}$

3
3
0
0
0
0
0

8

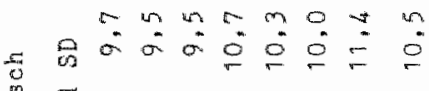

$m=200 \%$

$\prod_{\rightarrow \rightarrow-1}^{\infty}$

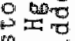

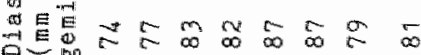

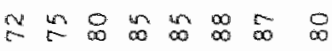

$\sum_{t a i}$

If

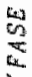

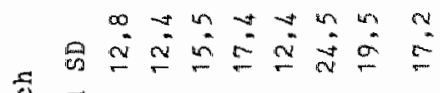

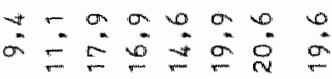

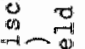

ging

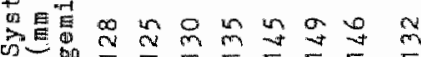

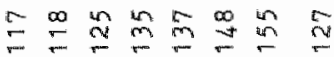

is

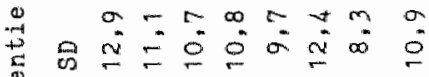

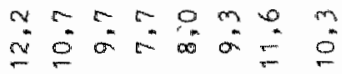

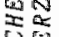

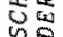

$\rightarrow=$

30

Es

$\sum_{0 \rightarrow 1}$

Siction

sid

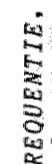

(i)

$5 x$

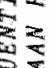


(2)

0

皮

0

0

as

to

4

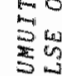

$\rightarrow-\infty$

in 4

W

a

i

$\rightarrow$ क

tos

os

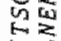

$\rightarrow \infty$

造

点电

2

$\log ^{\mathrm{T}}$

is

$-5$

$-6$

45

in 2

$\rightarrow-1$

$\rightarrow$ int

(⿻in)

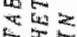

and

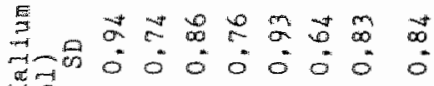
政邑

E

$\rightarrow-10$

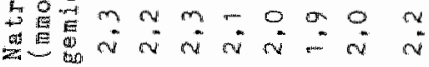

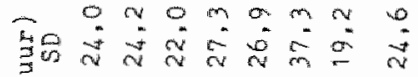

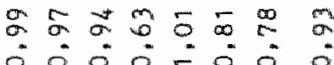

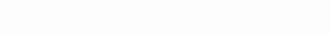

$m m m \infty=\infty$

m $\infty$ un 25 a

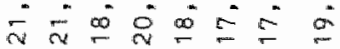

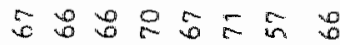

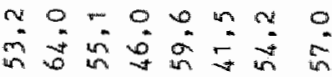

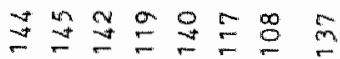

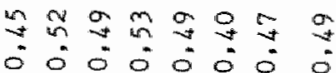

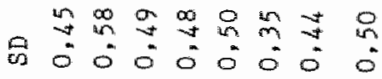

$=0$

$m= \pm$ in

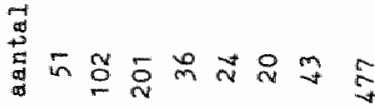

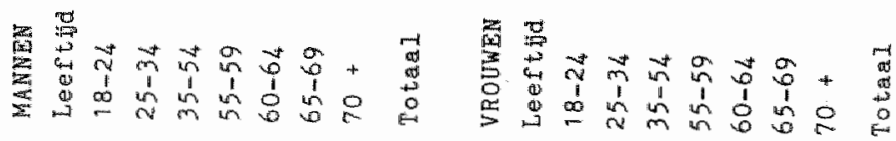




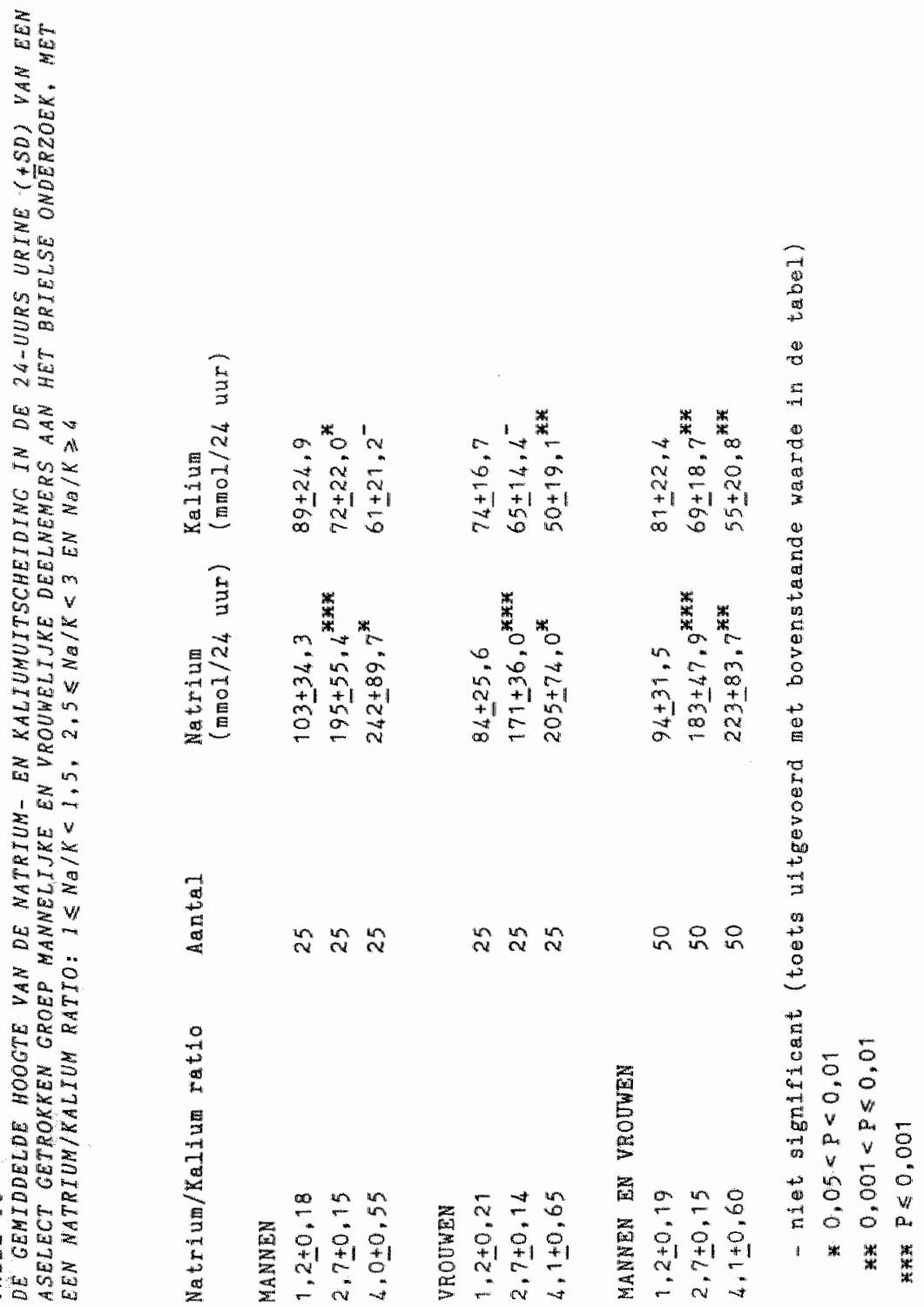




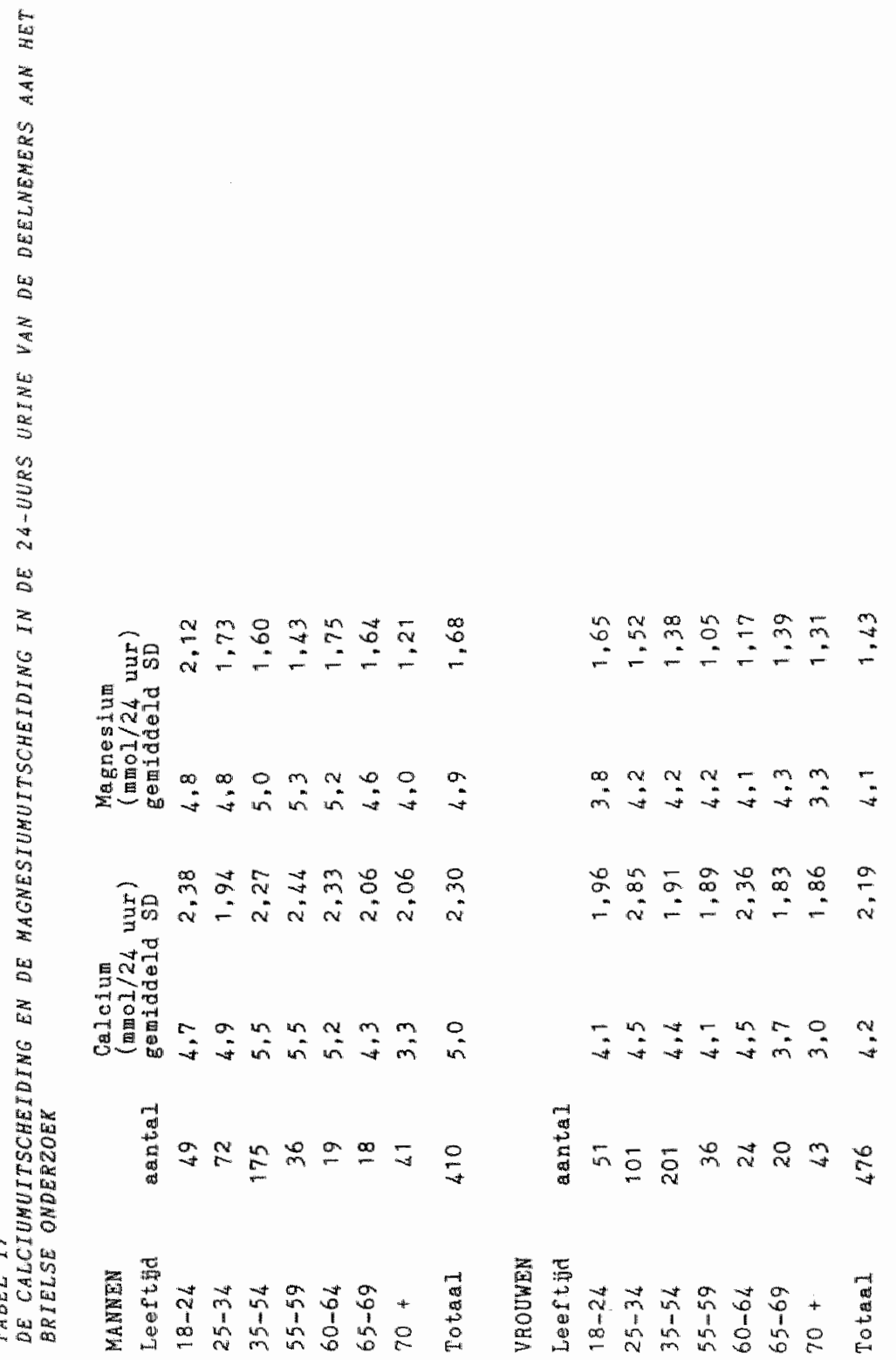




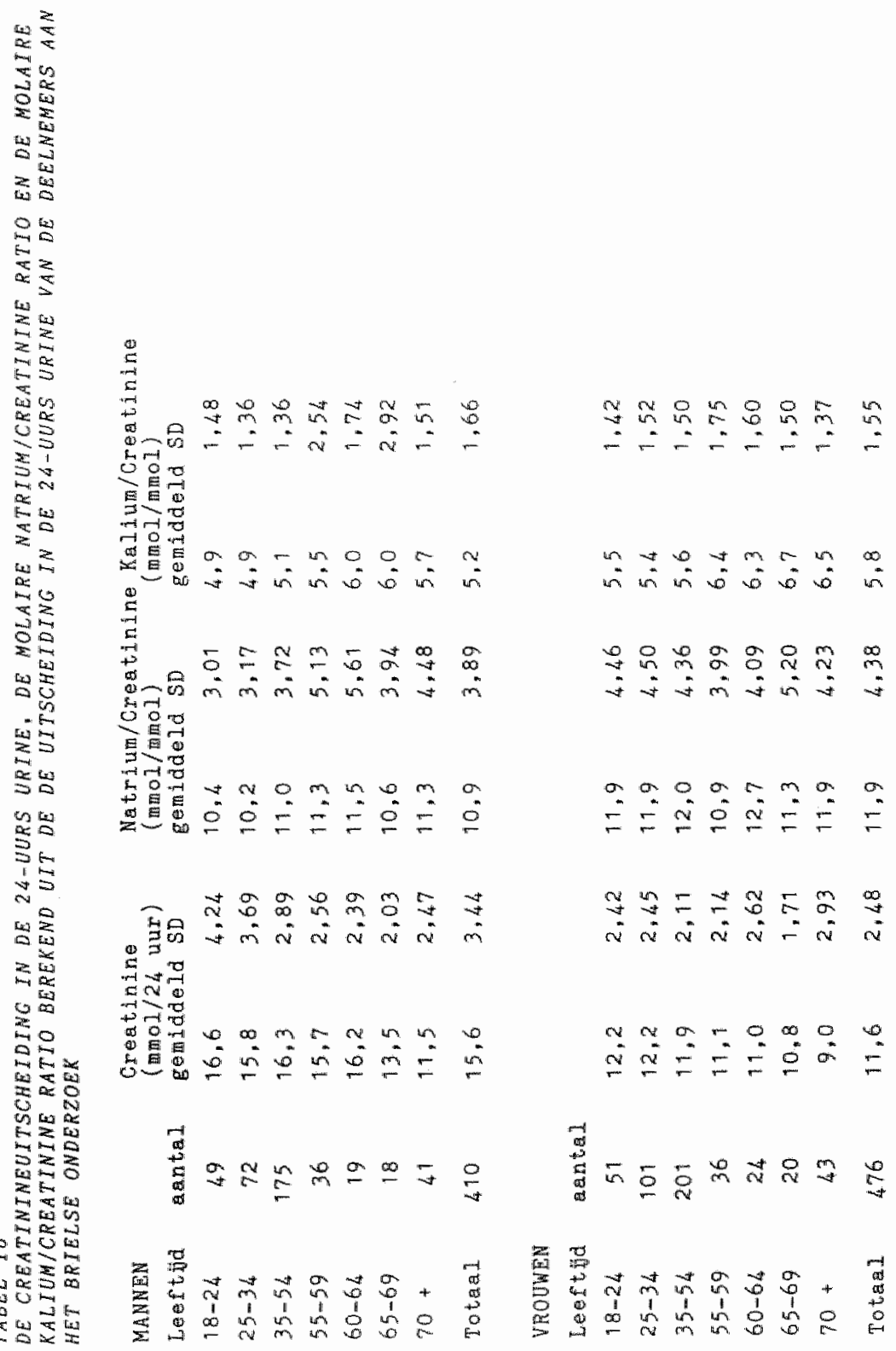




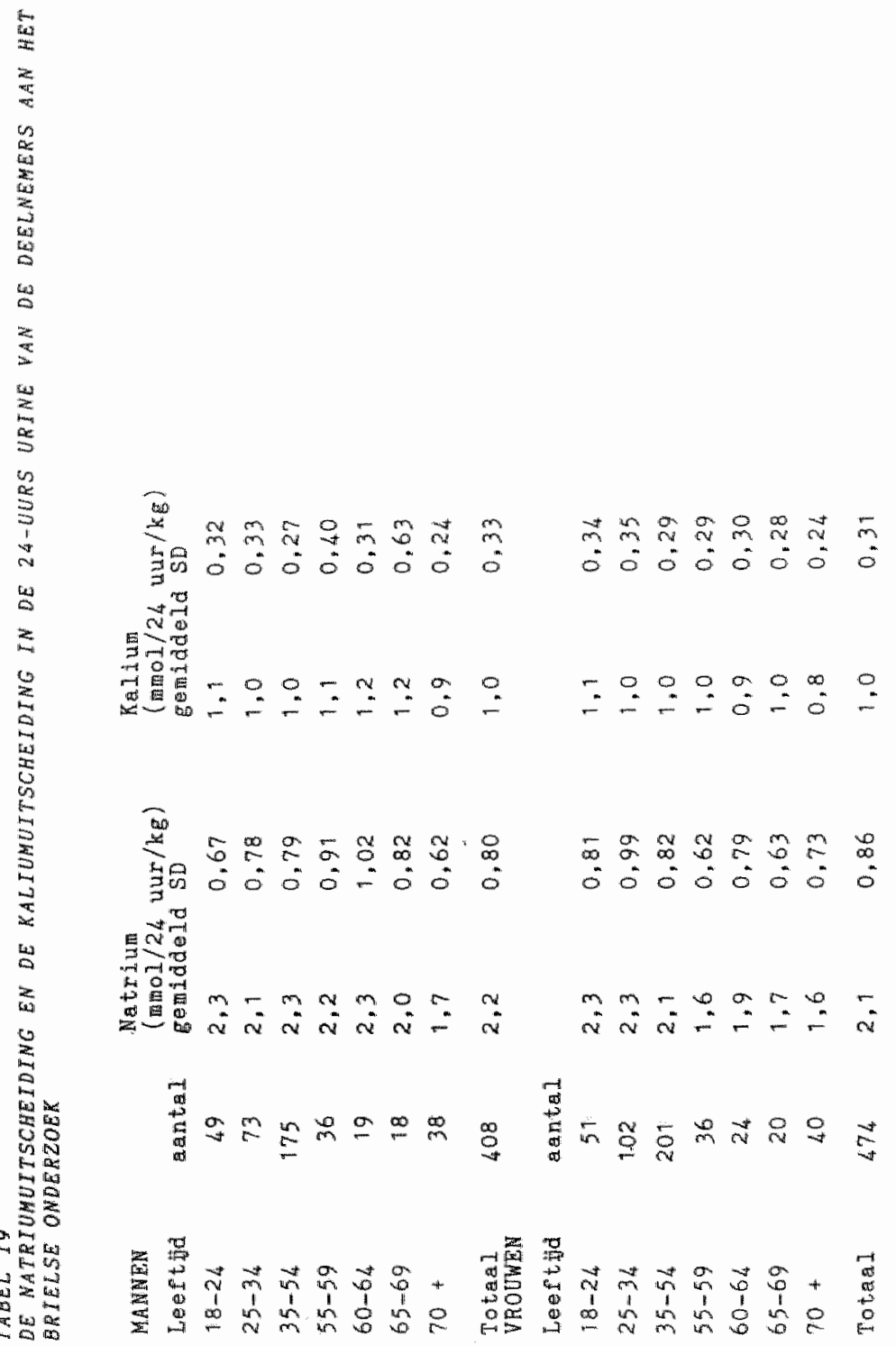




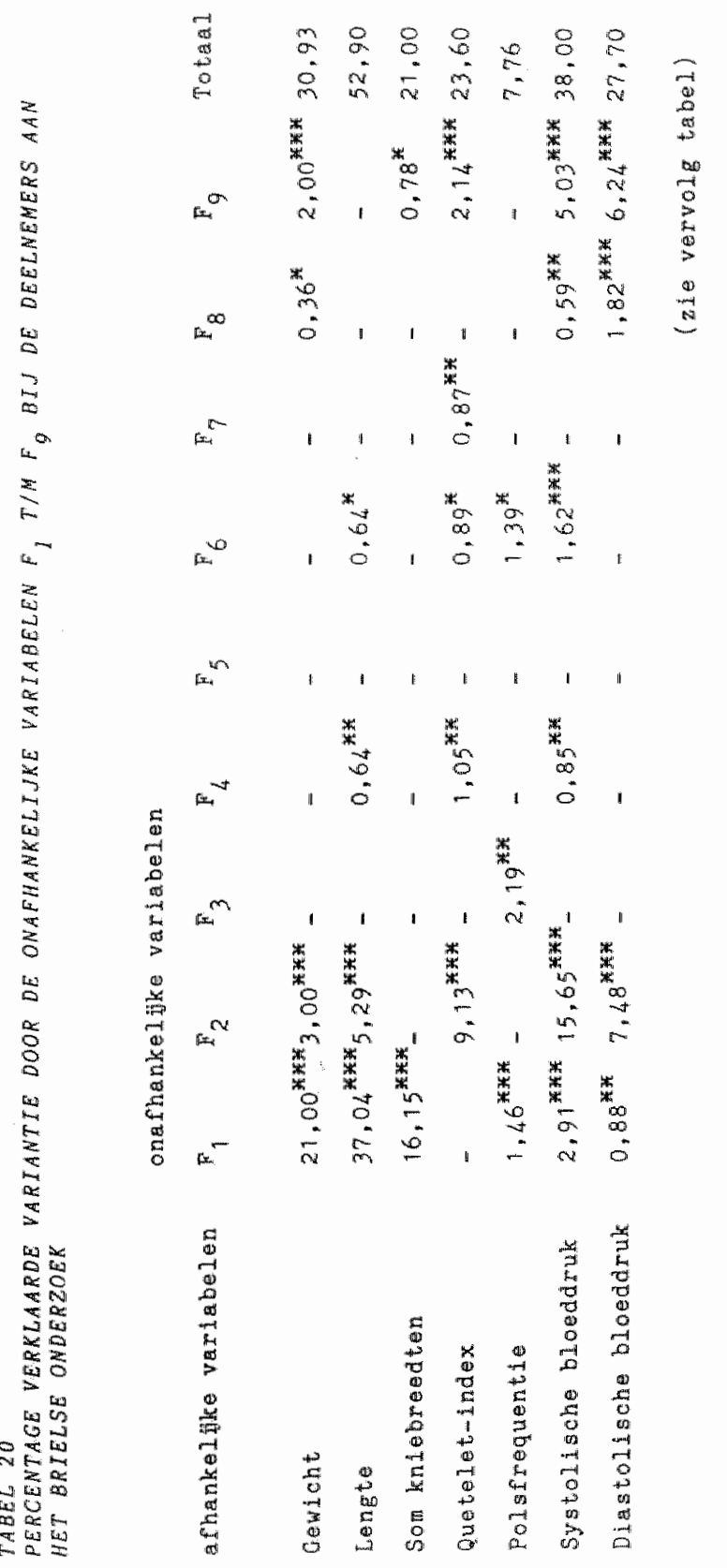




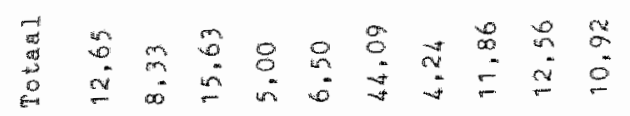

$x_{\infty} 1+1,1+1$

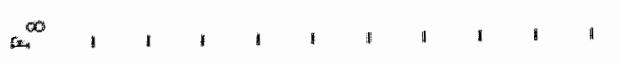

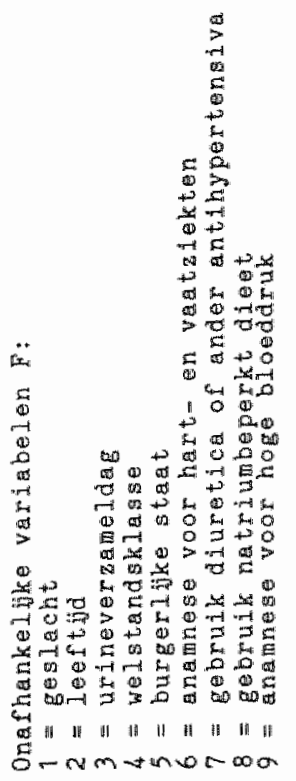

0

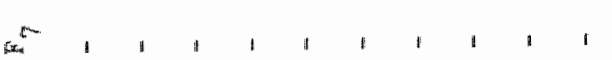

$1,1,1,1$

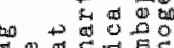
if $B$ 10 of

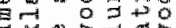
ad 0 a int in

क्ष

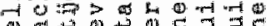

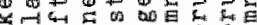

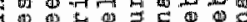

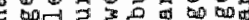

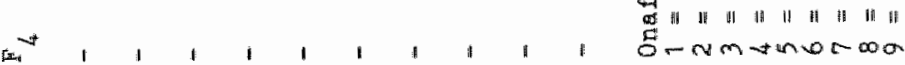
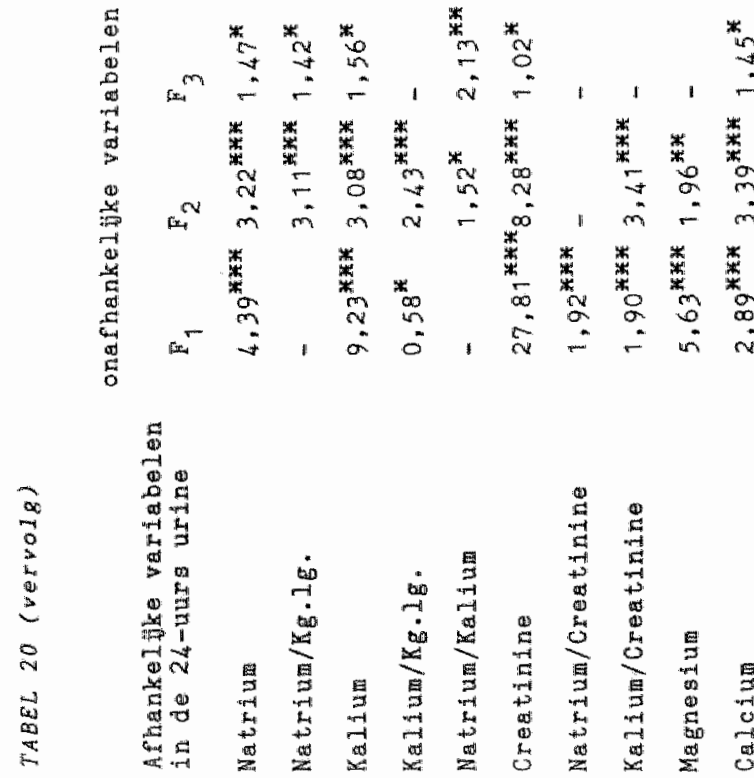

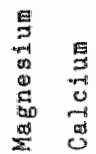

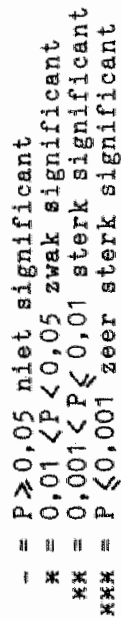




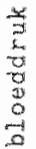

0.1
0

0 in

tog $\operatorname{tin}_{0}$

$3 \rightarrow \mathrm{B}_{0}$

此 Ex

50

4 0

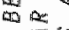

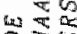

2

$\therefore 0$

$0 \mathrm{CH}$

$+1 c^{4}$

wa

$\geq \infty$

$\infty \mathrm{si}=$

in $0=$

an 0

$\$$ ton

45
का को

40

in

$5 \infty$

$2 \frac{5}{4}$

00

20

a

to $N$ N

एक

$\operatorname{ton} 2$

$\rightarrow 00$

$\sum 0 m$

$\rightarrow \infty$

एक

Let

$\geq \quad 5$

$\sum_{1}+2$

$10 \div$

$3+1$

4

$\rightarrow 0$

단

cos of

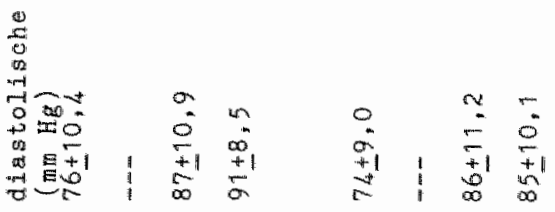

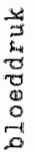

a

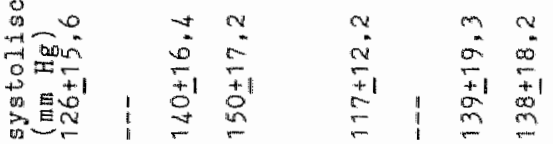

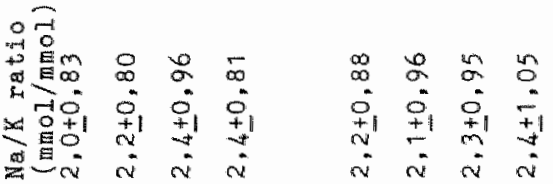

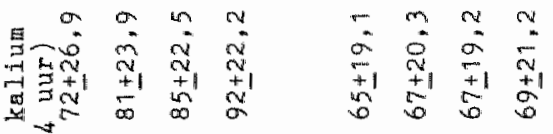

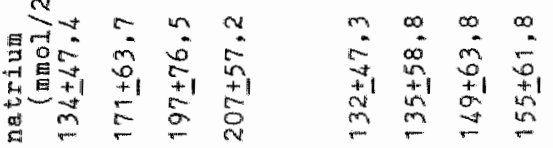

$\geq$

$>+2$ in

5 tes

तो $x$

in 08

an 0

or $x_{2} b^{2}$ the

$\rightarrow 5+2$
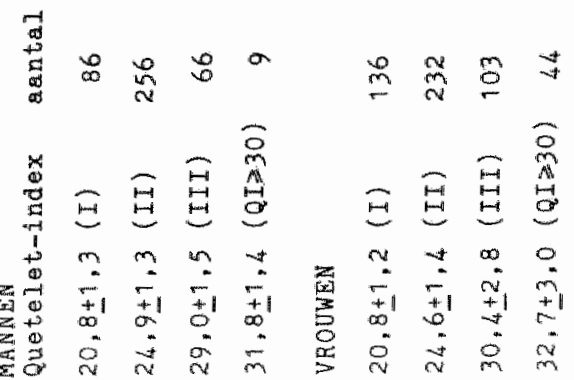


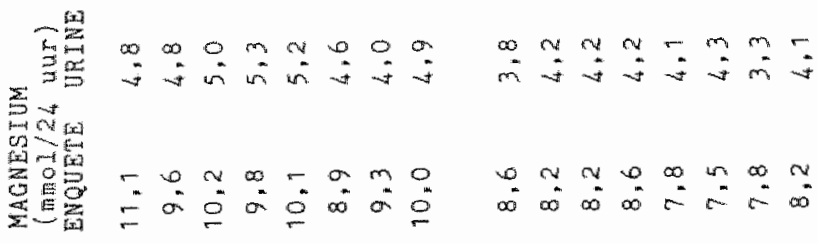
憵

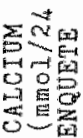

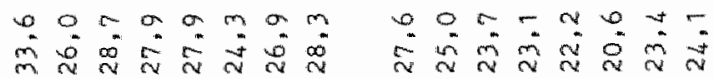
幽罢 용 焉焉

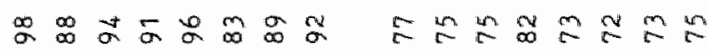
sin 


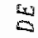

$\sum$

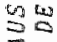

$+2$

$\sum$

2.

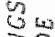

$\geq 0$

9

为

i

$\sum_{i}$

$\pm 0$

$\sum 8$

30

\&

of

tis 0

40

50

$\rightarrow \infty$

Es

留客

w w

in

过

$\sum k$

0 만

$\geq x$

$\rightarrow$ is

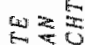

$x+5$

$9 \sin$

$=\infty \frac{\pi}{6}$

04

in

2 C.

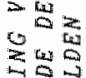

4 出

$a \pm$

5xil

$\therefore \rightarrow$

Ix

[난)

an

50

$\operatorname{mos} 5$

$\log 50$

$\rightarrow 01$ ace

is $\rightarrow \infty$

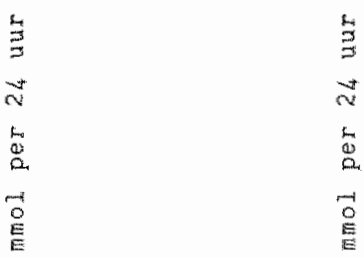

$\begin{array}{lllllll}9 & 0 & 0 & 0 & 0 & 0 & 0 \\ 9 & 0 & 0 & m & 0 & 4 & 0\end{array}$

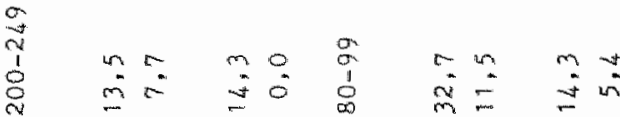

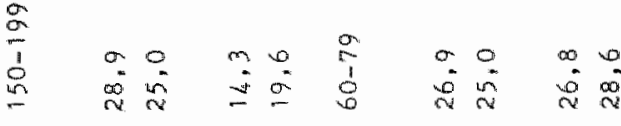

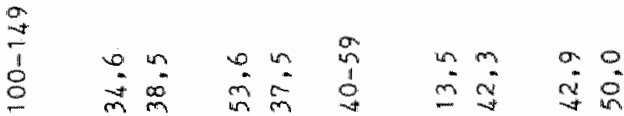

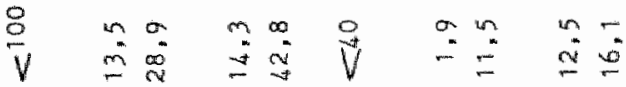

离题

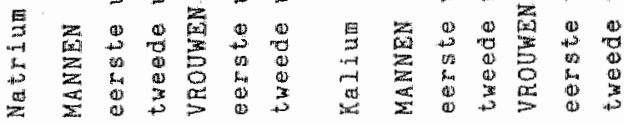




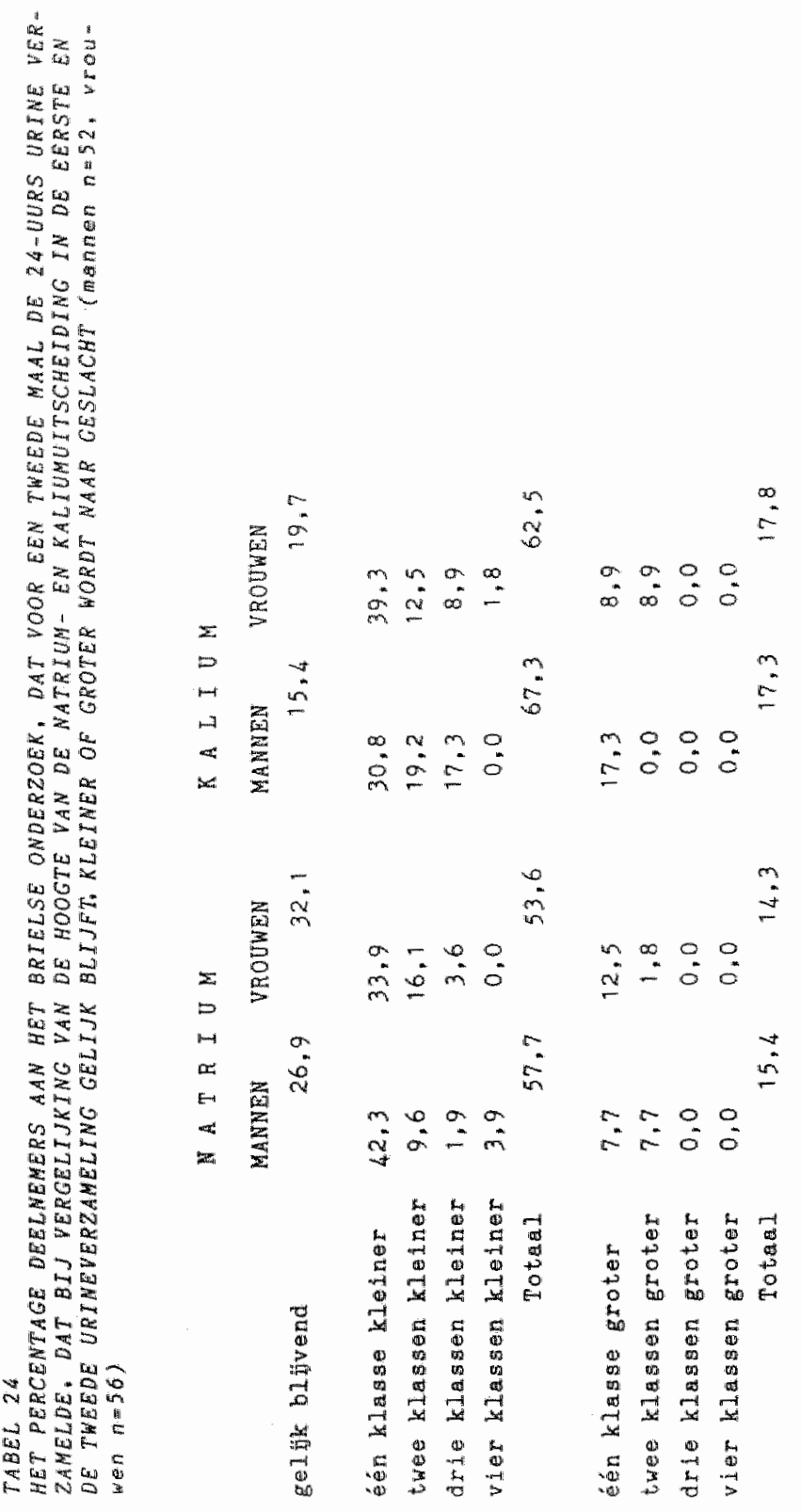




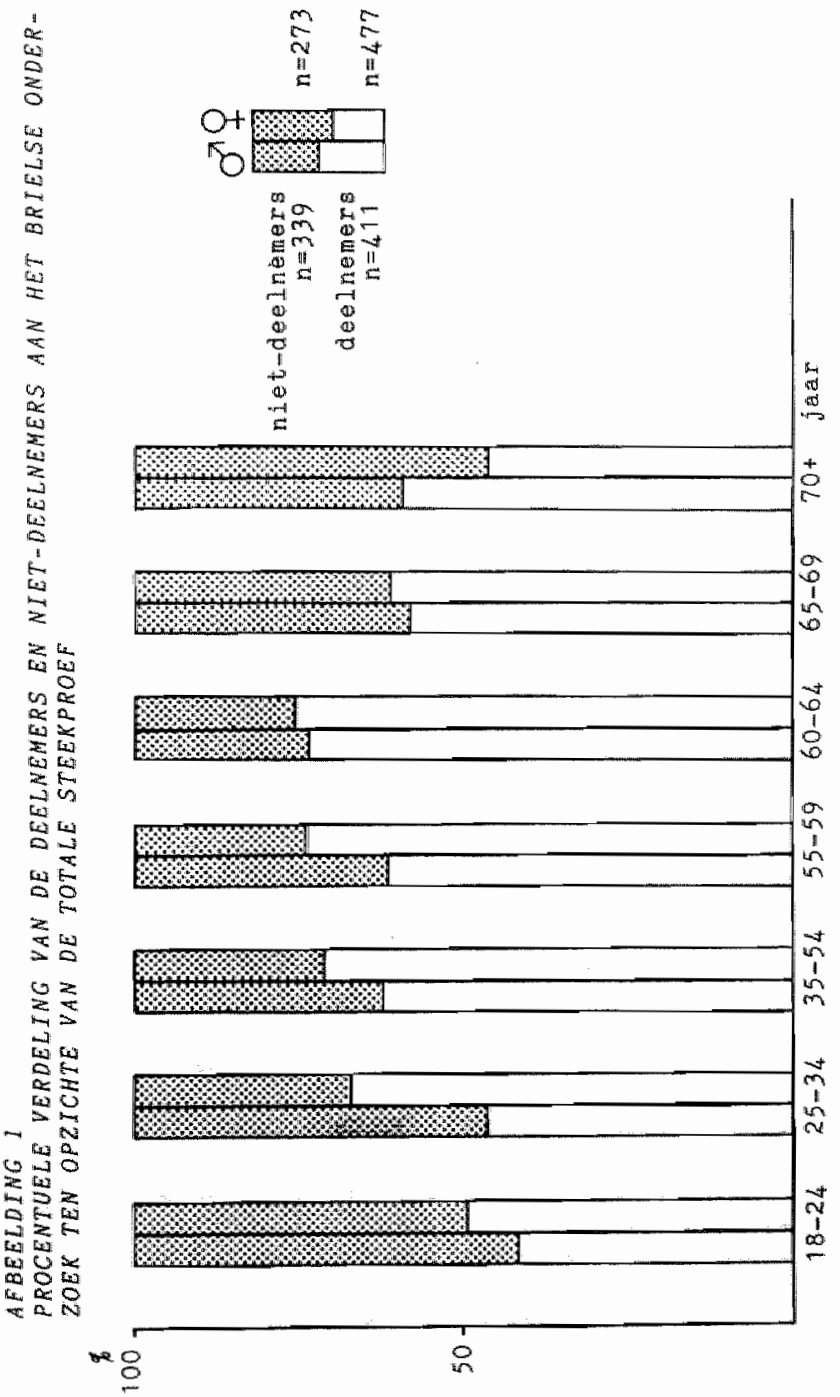




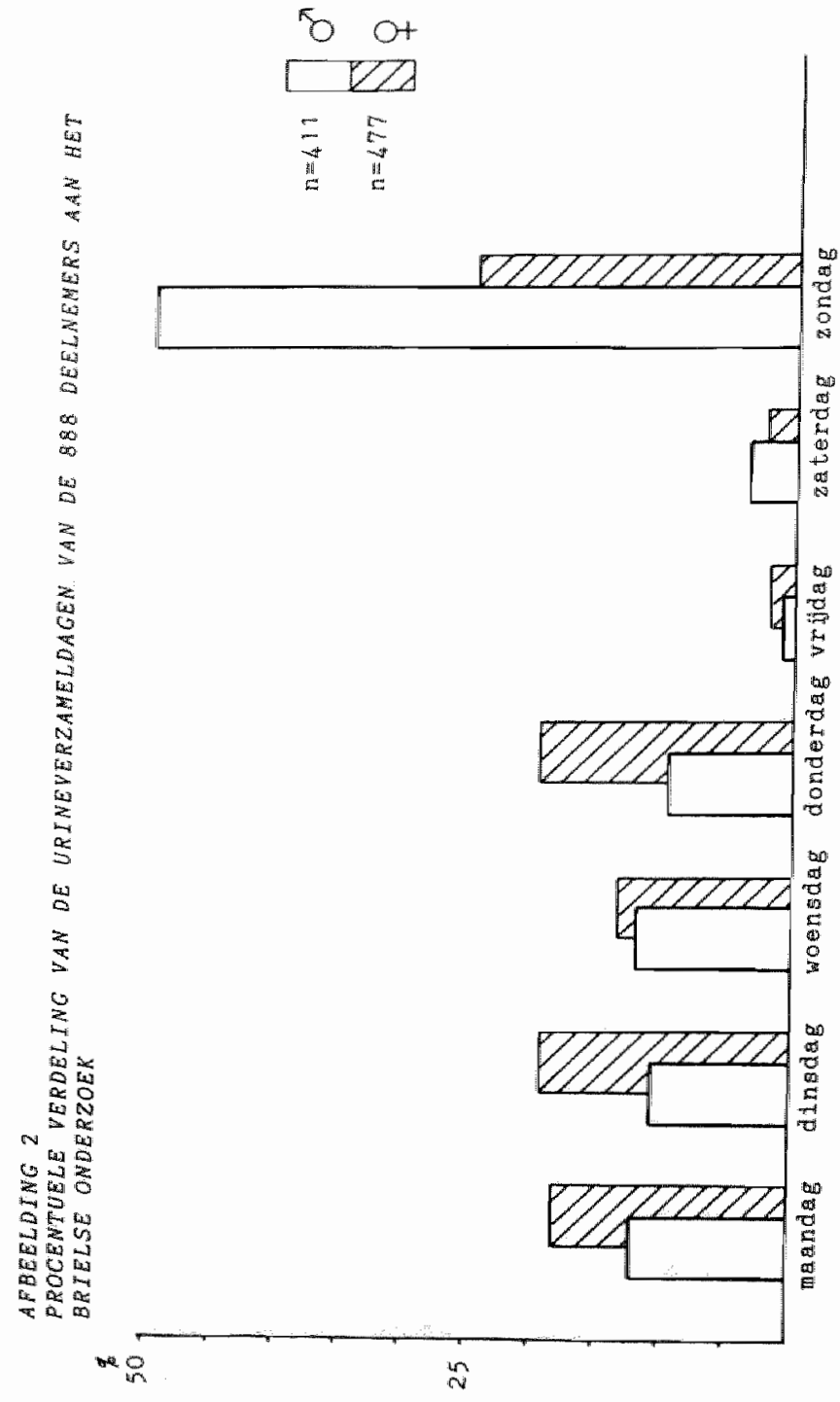




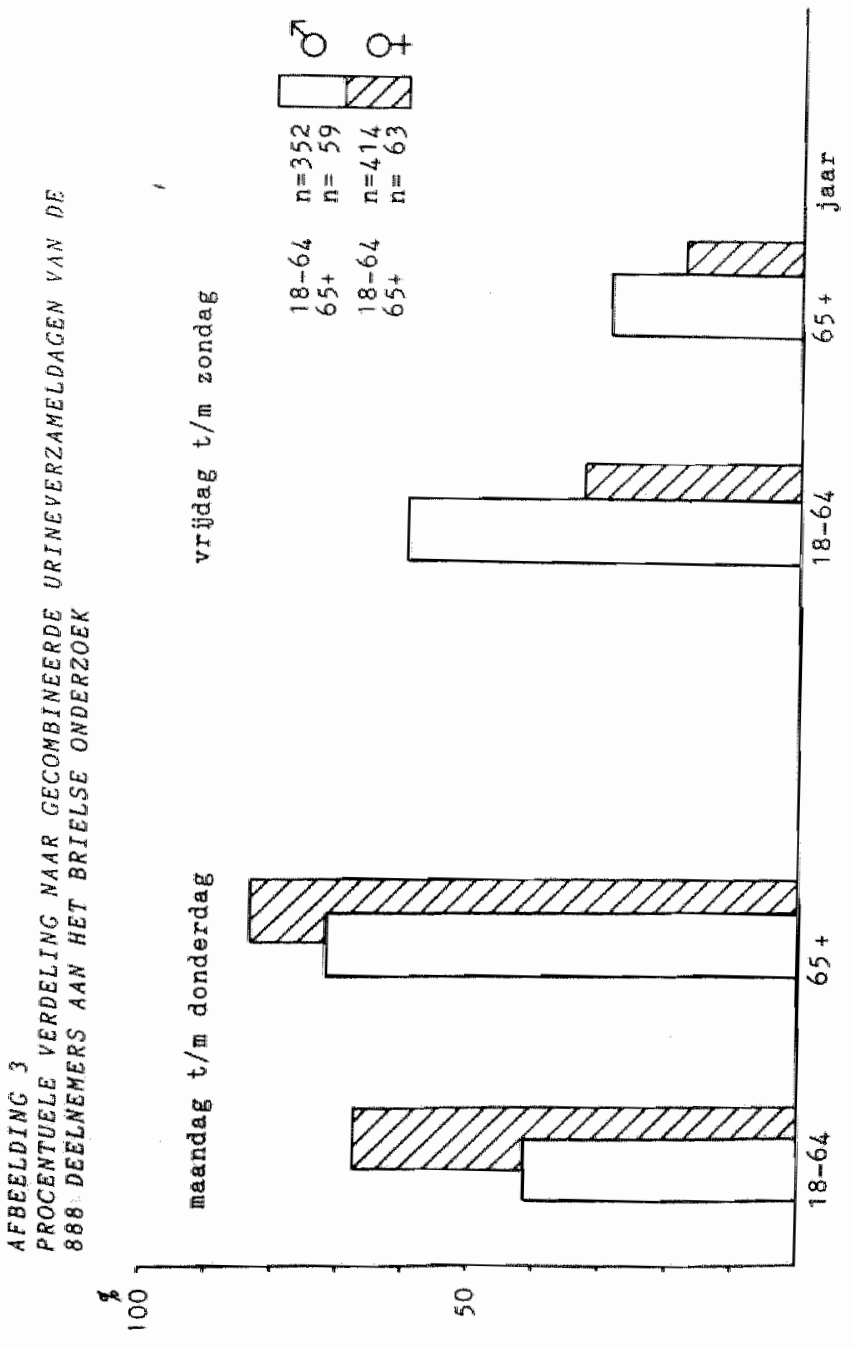




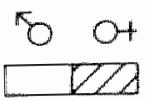

$\begin{array}{ll}m & 5 \\ m & 0\end{array}$

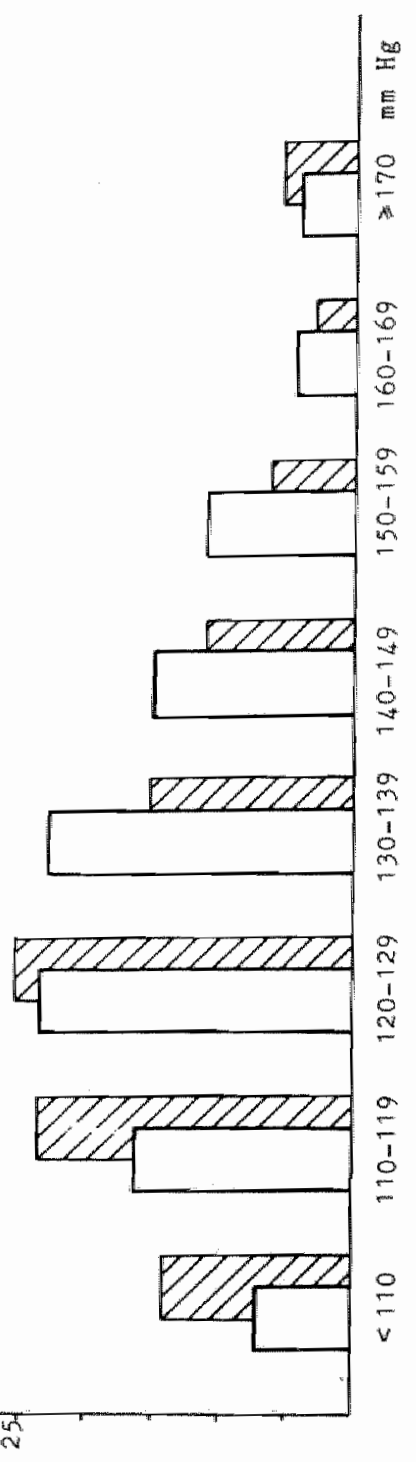




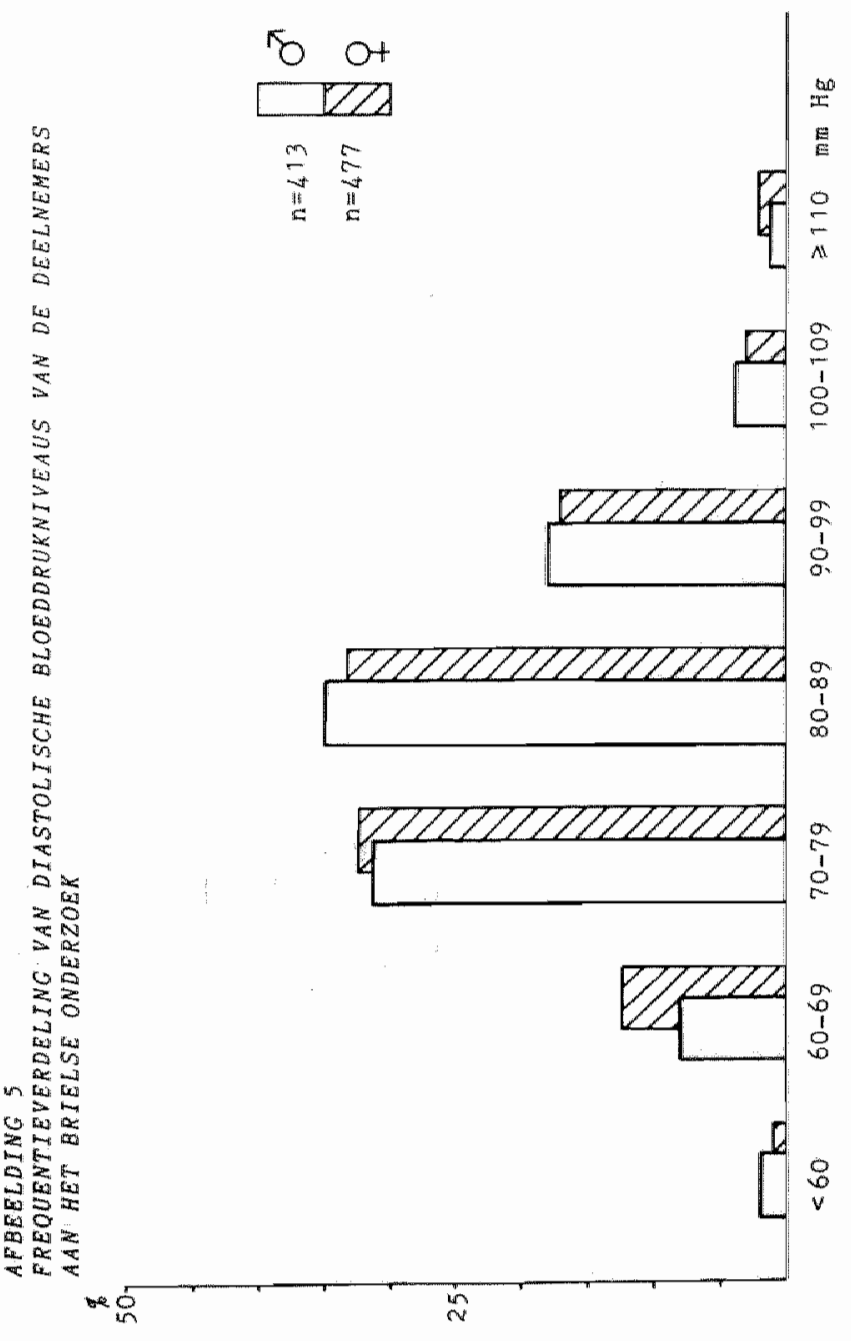




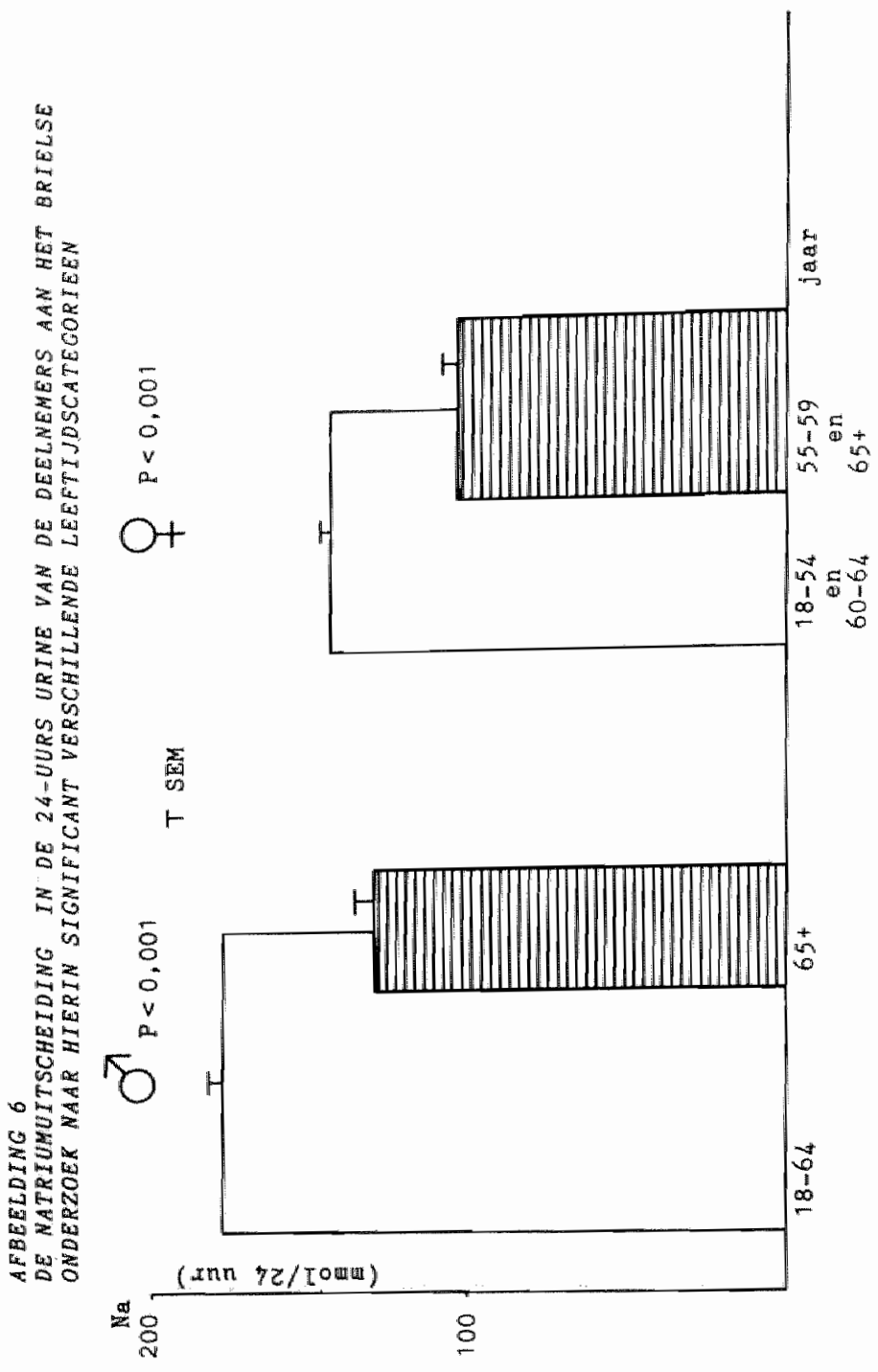



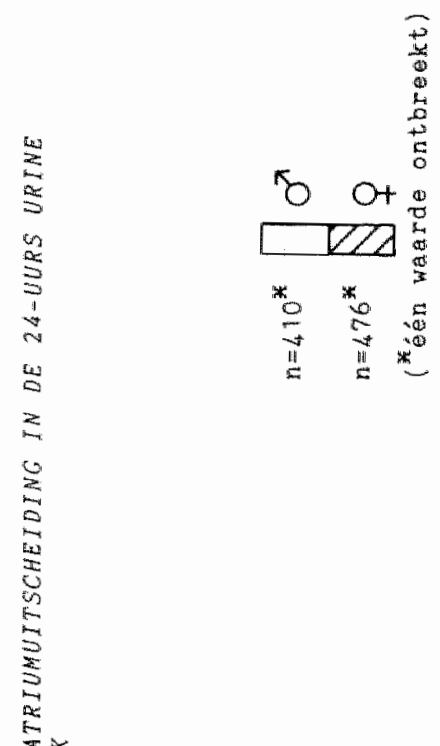

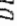

20

w

0

중

Wi: they

(a)

Sa

은

$\infty$

a.

$-x$

뜬

$\leq$

ए ए

mat $a$

[ix) $\mathrm{Co}$

ID 4

Non

Co 6

at in

10

300

in 0

aid 10

ए $x x_{1}=$

3
0
0
0
0
0

9
8
2
0
0
0
3
3

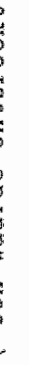

ve

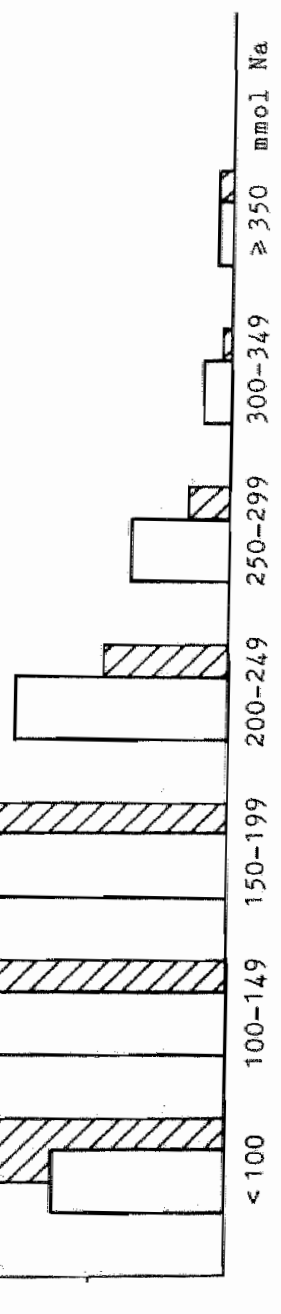


$A F B E E L D I N G B$

APOCNTUELE VERDELING VAN WE WOOOTE VAN DE NATRRUMUTTSCHET

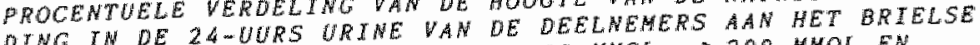

DING IN DE 24 WURS URTME VAN OWDEROEK VEMOEELD IN WIEAUS $\geq 300$ HMOL MATRIUM

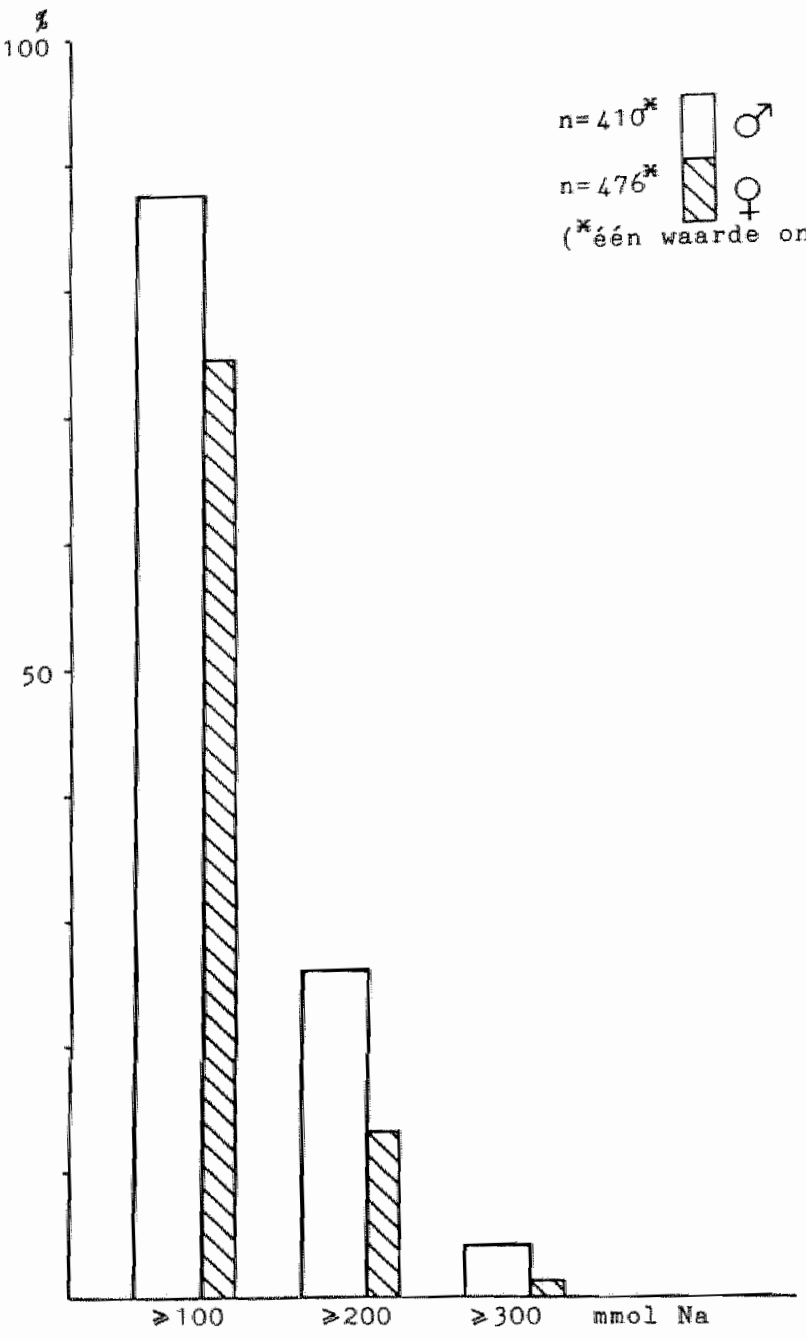


AFBEELOTNG

PROCENTEELE VERDELING VAN DIVERSE URINE NATRTLARXCRETTEWIVEAUS WAN DE DEELNEMERS AAN HET BRIELSE ONDERZOEK
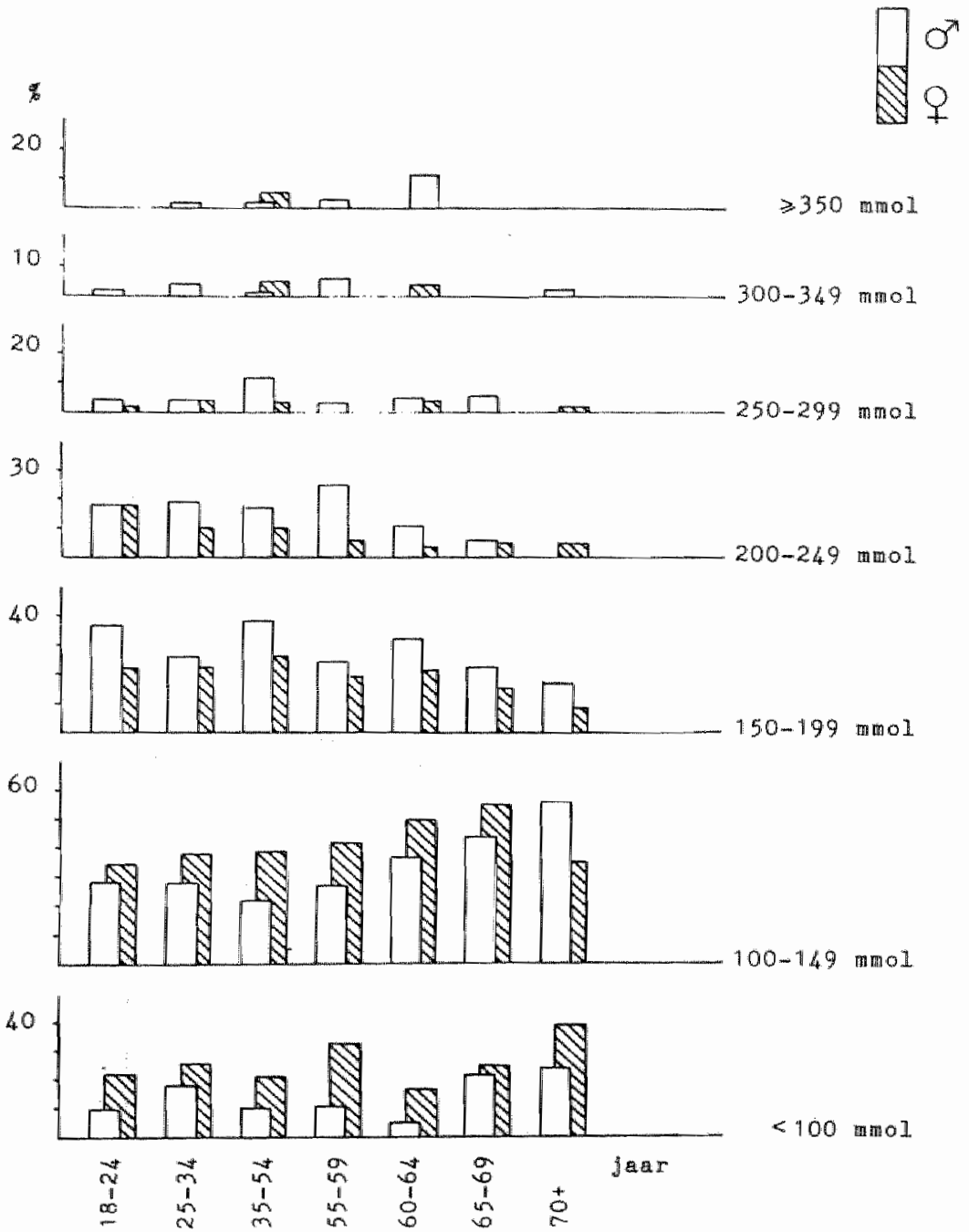


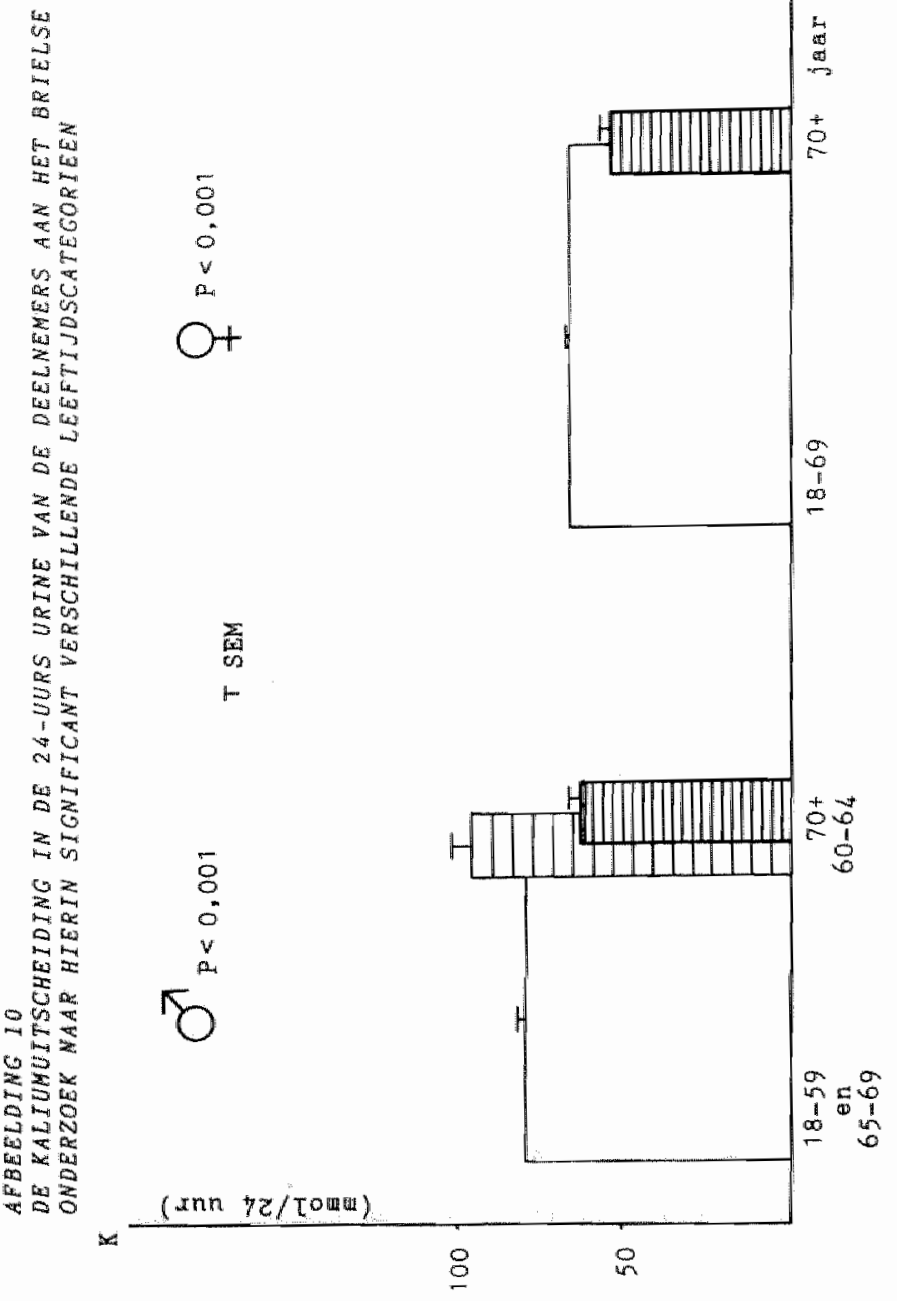



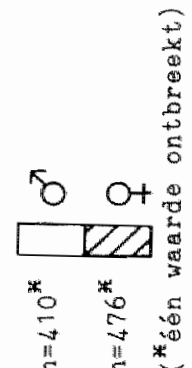

$\stackrel{8}{g}$

is

3

2

5

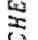

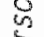

5

$-1$

$x$

교용

0

$\geq 0$

50

is on

60

$9 \mathrm{~m}$

음

s.

0 t?

$\geq$

$\leq 2$

0

$\sum_{i}$

iㅣ

ar

$7 \infty$

$=$

0 a

in

0

6) 5

[i] 0

년

is ar a

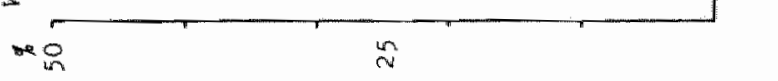


APBEERETHC 12

PROCENTUEHE VERDELTAG VAN OTVERSE URINE RALIUMEXCRETIENIEEAUS VAW DE DELLNEHERS AAH HET BRIELSE ONDERZOEK

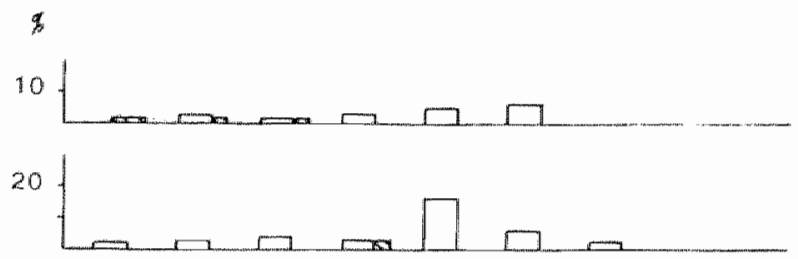
$120-139$ mol

30

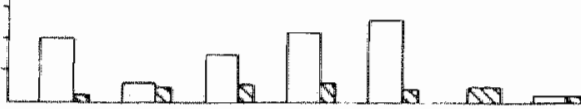

$\geqslant 140$ m nol

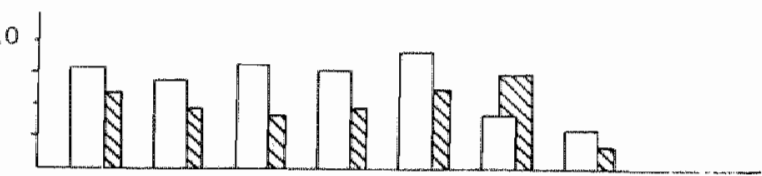

80-99 $\mathrm{mmol}$

60
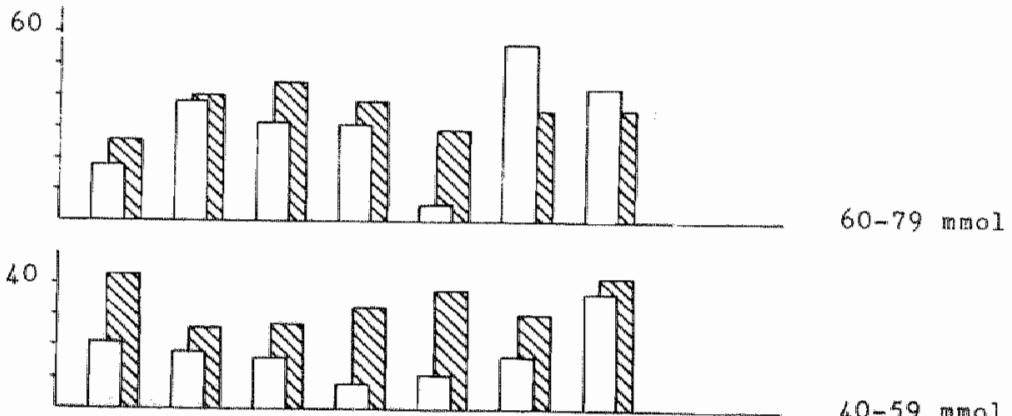

$40-59 \mathrm{~mol}$

20

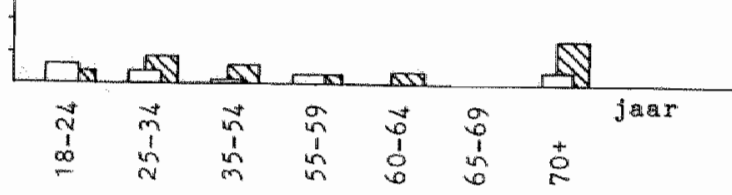

$<40$ mol 


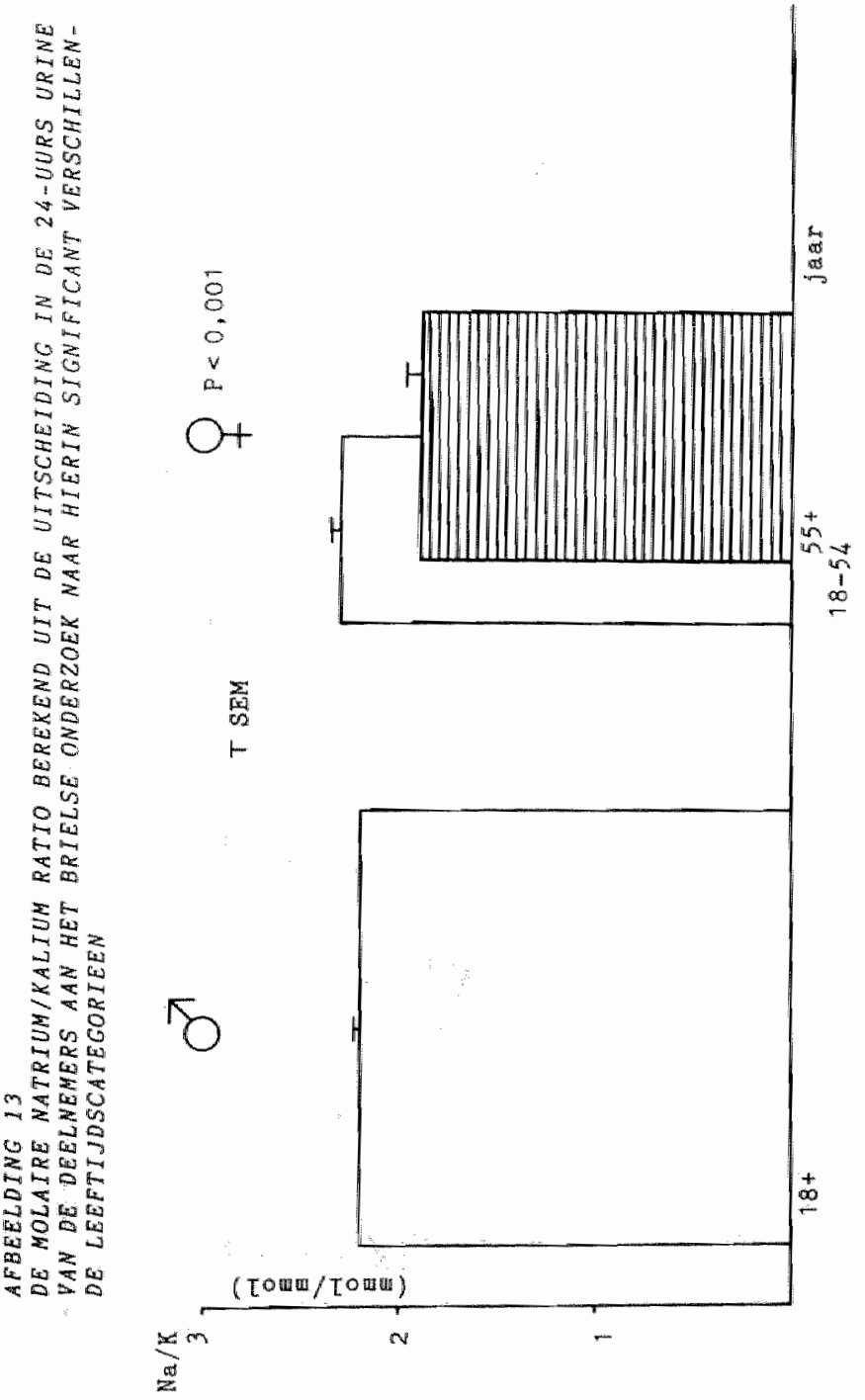




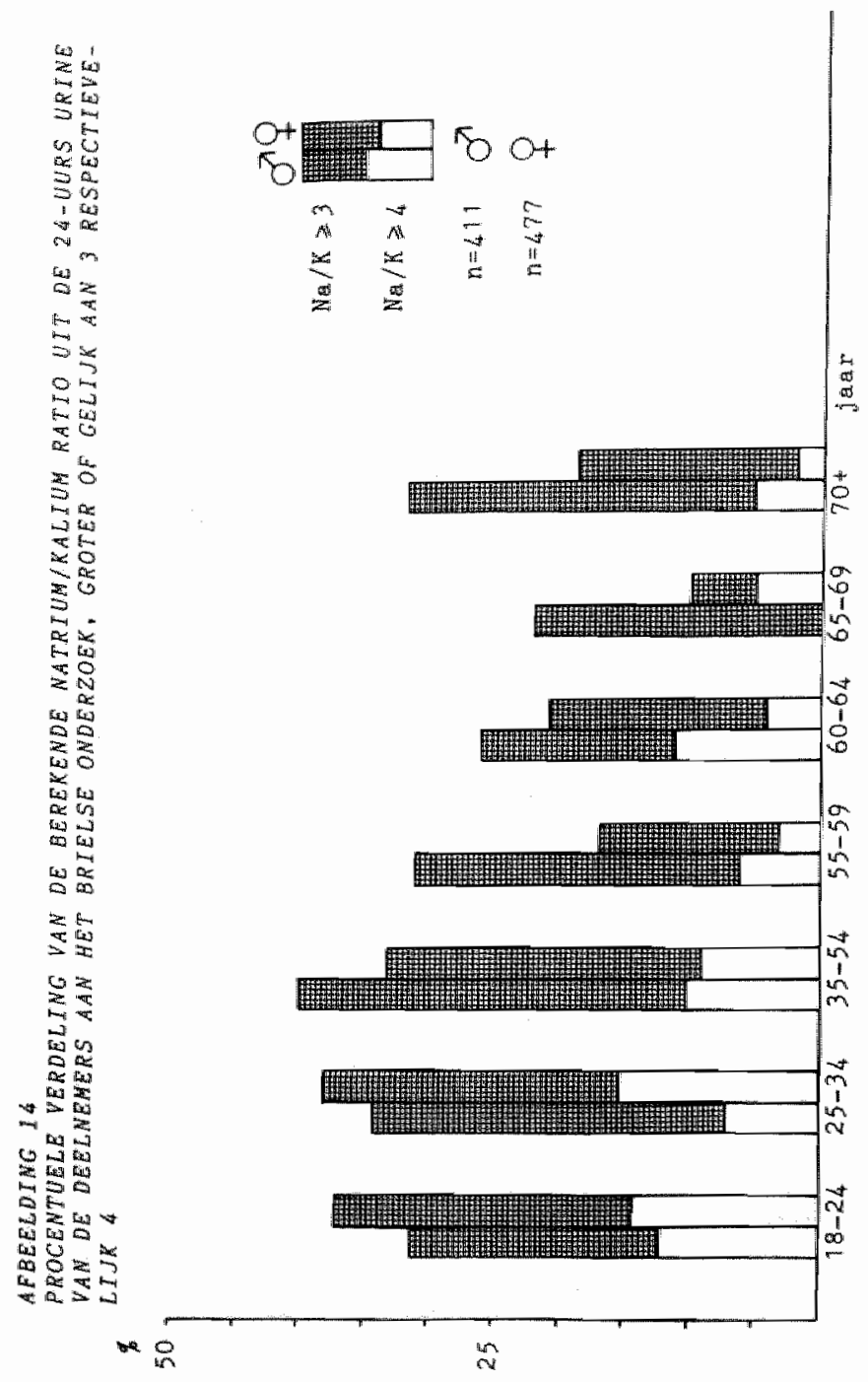




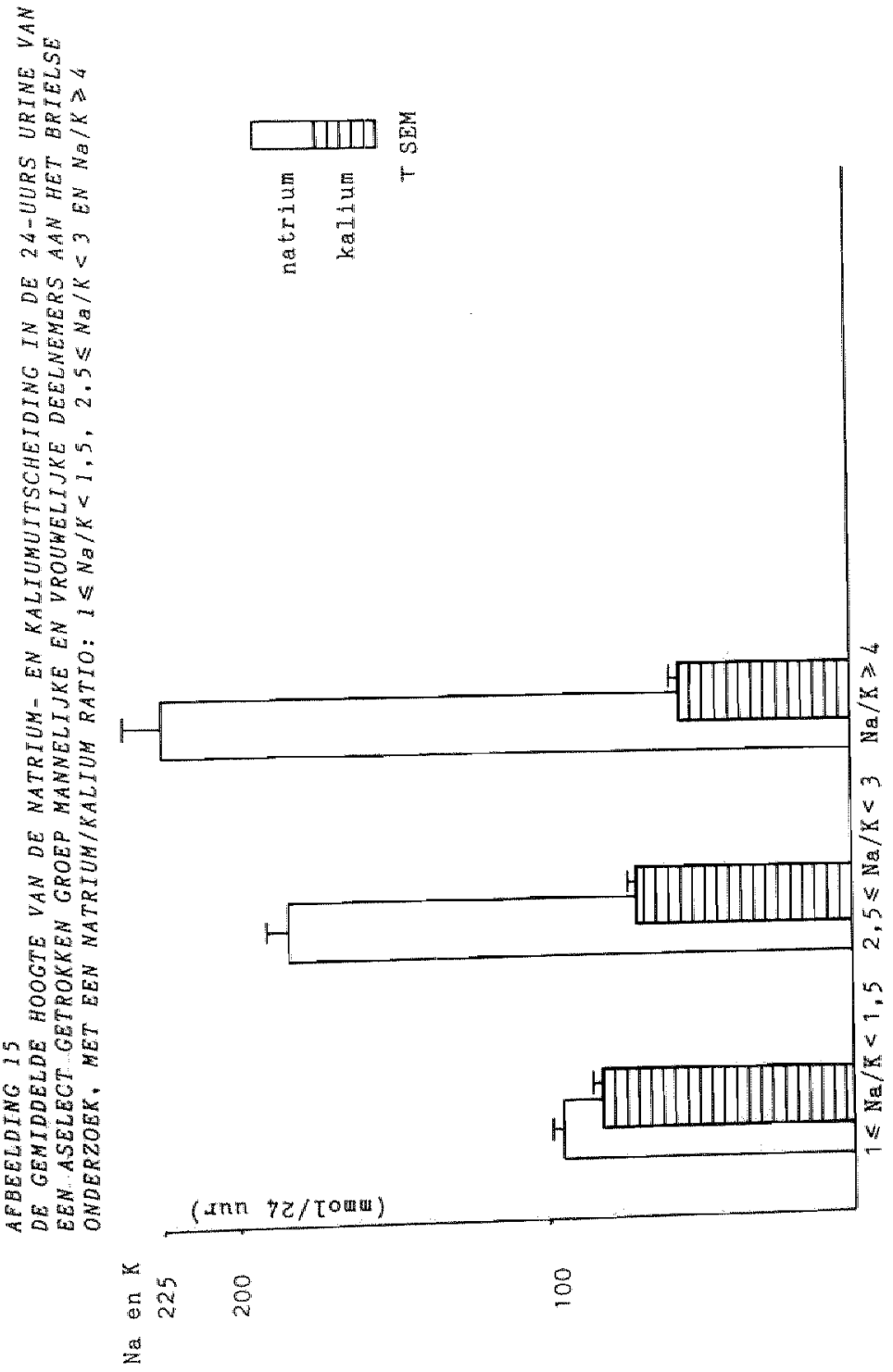




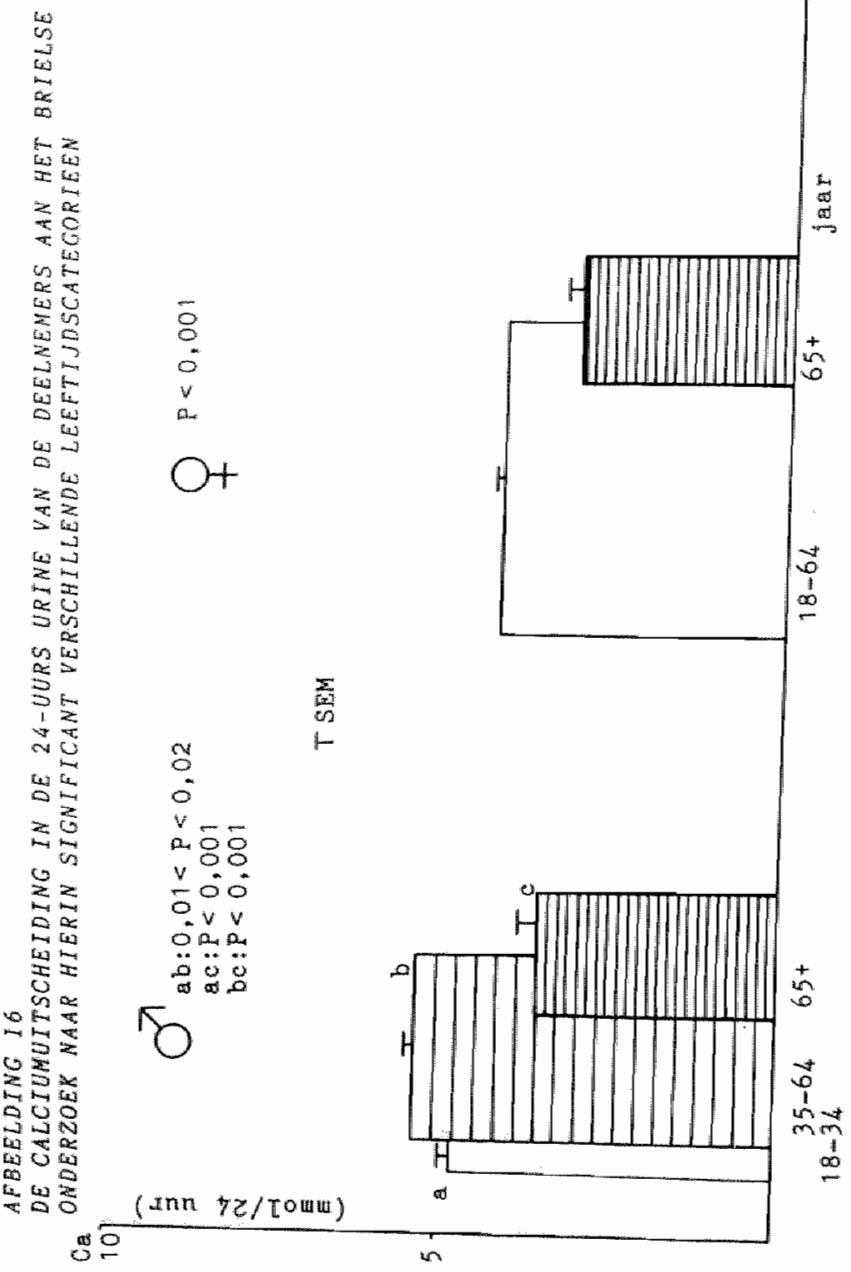




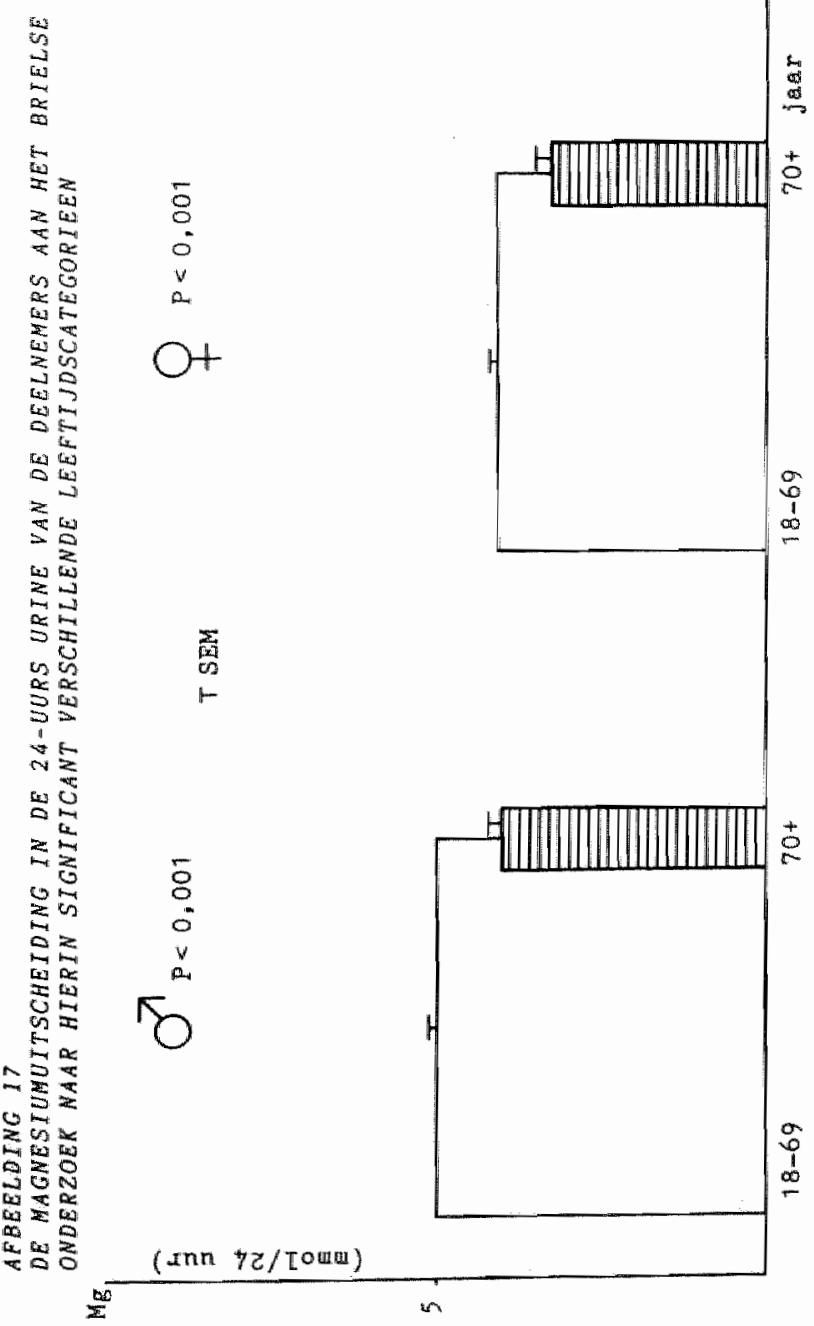




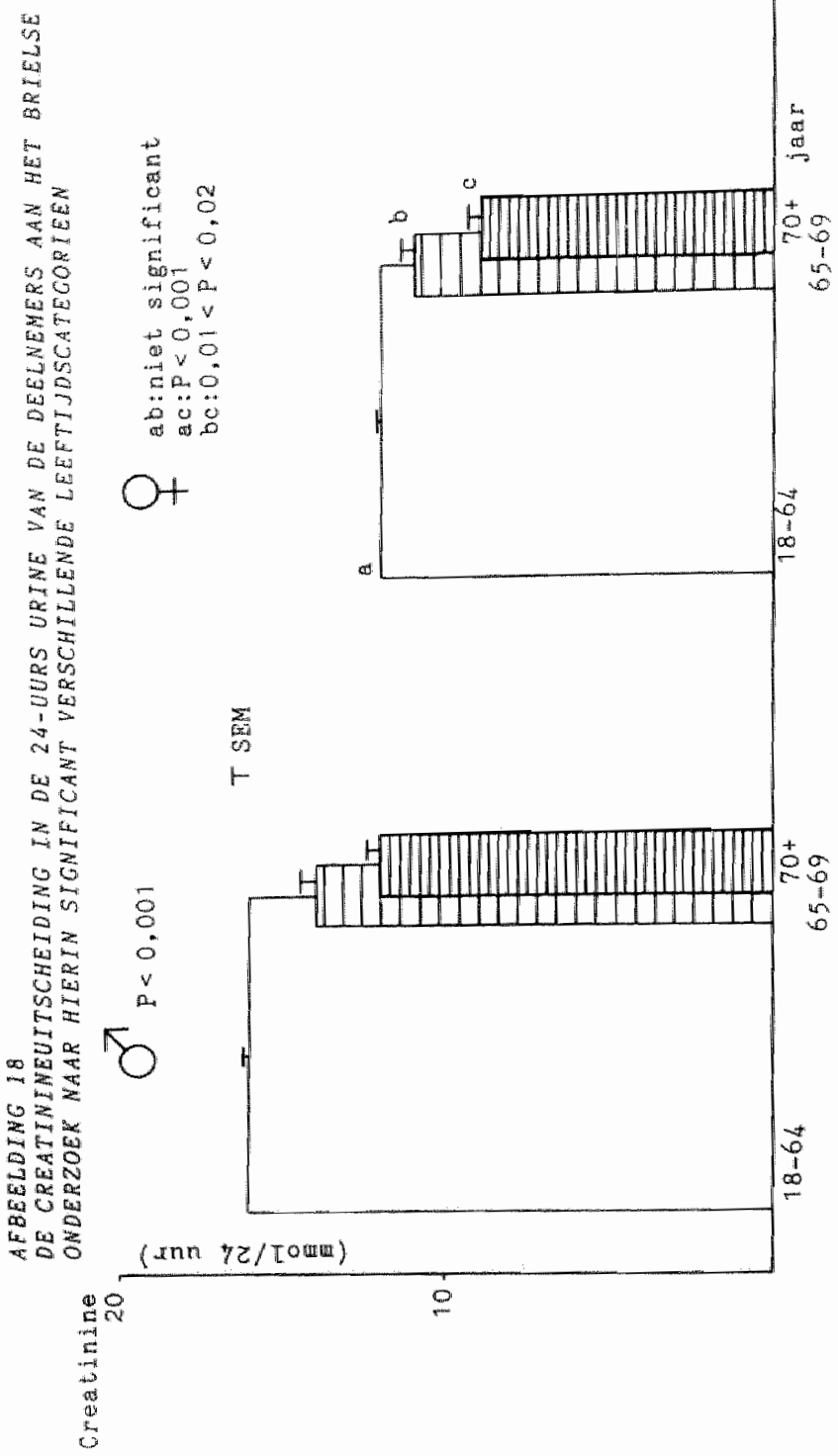




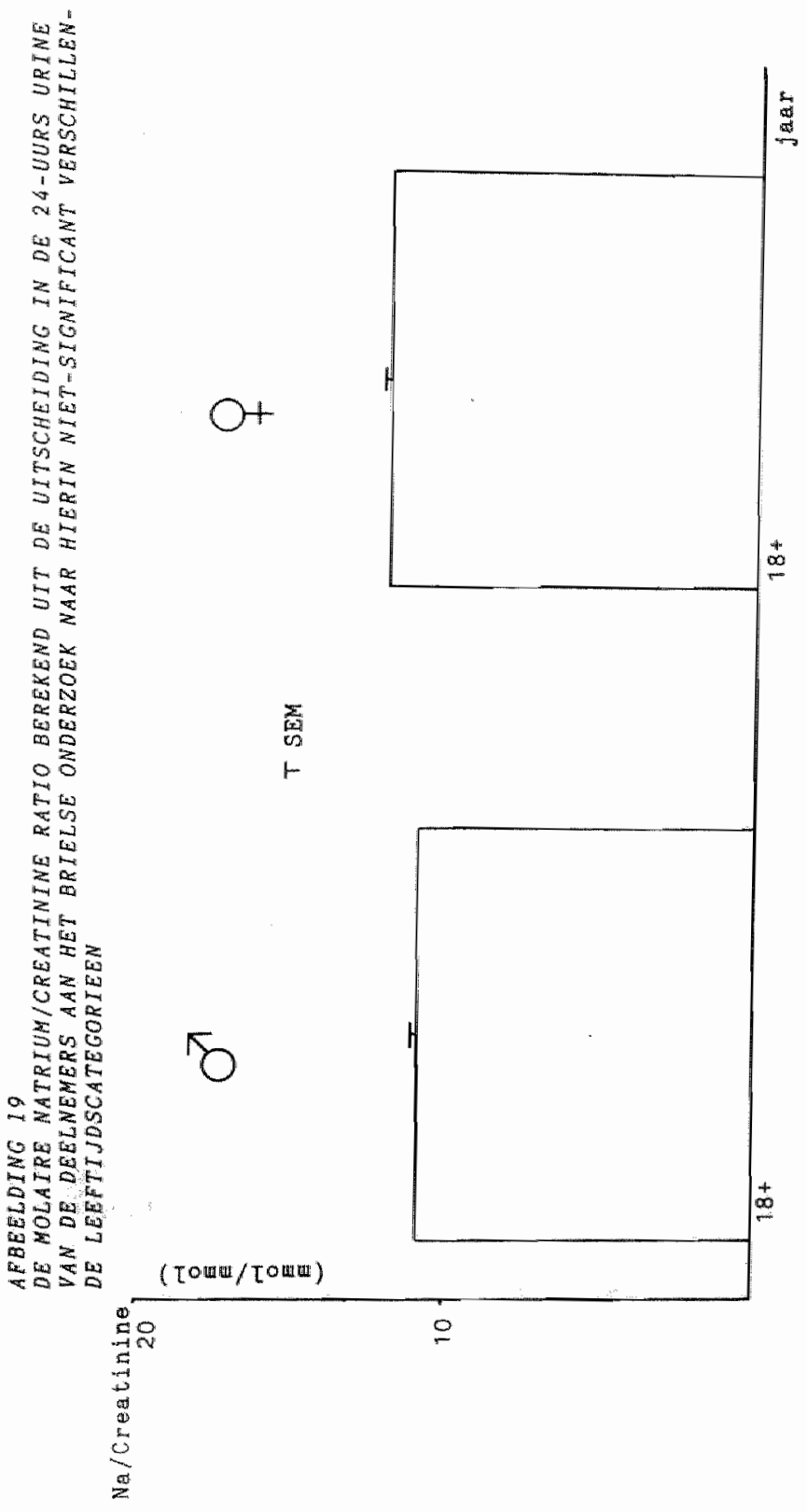




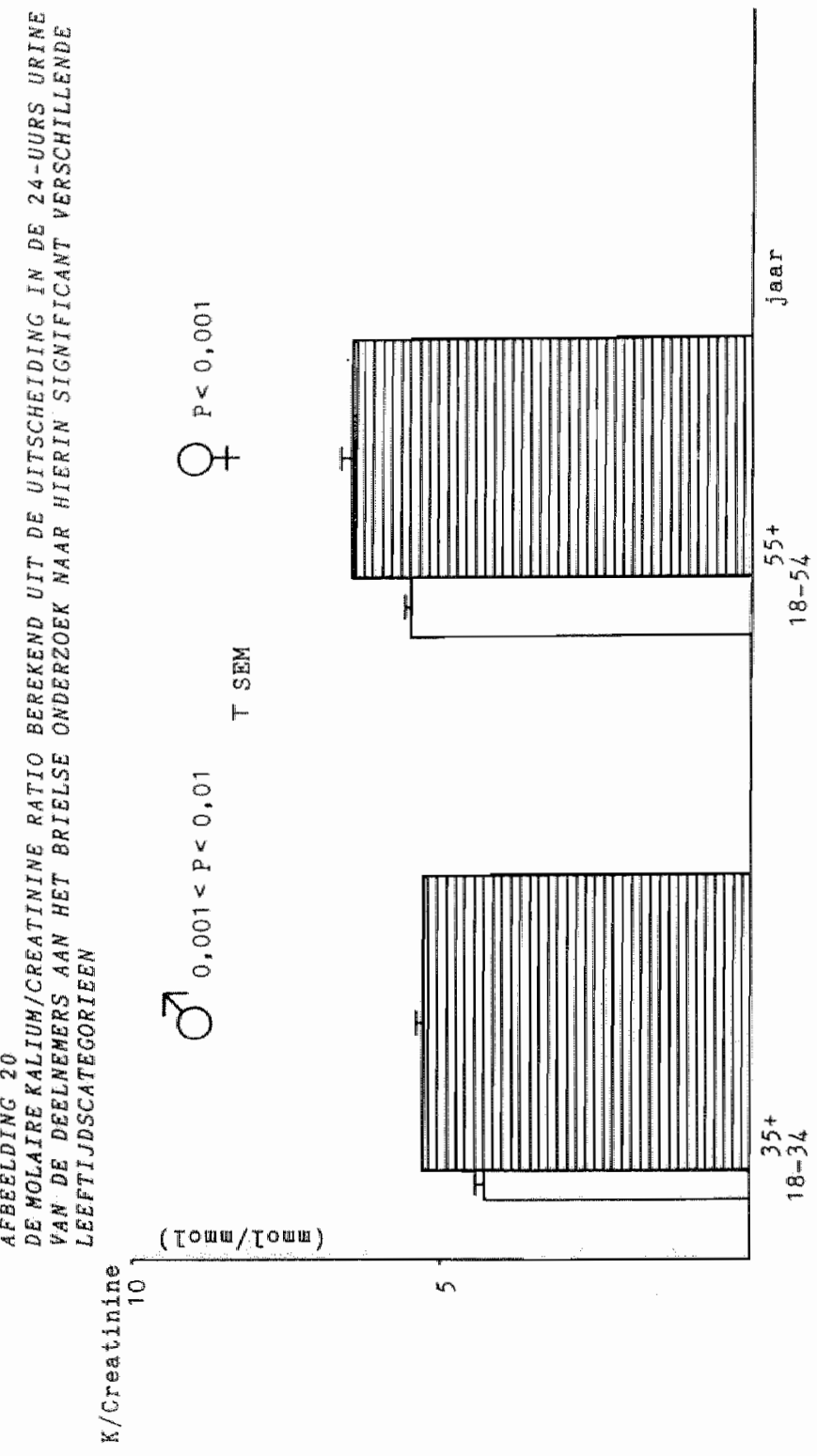




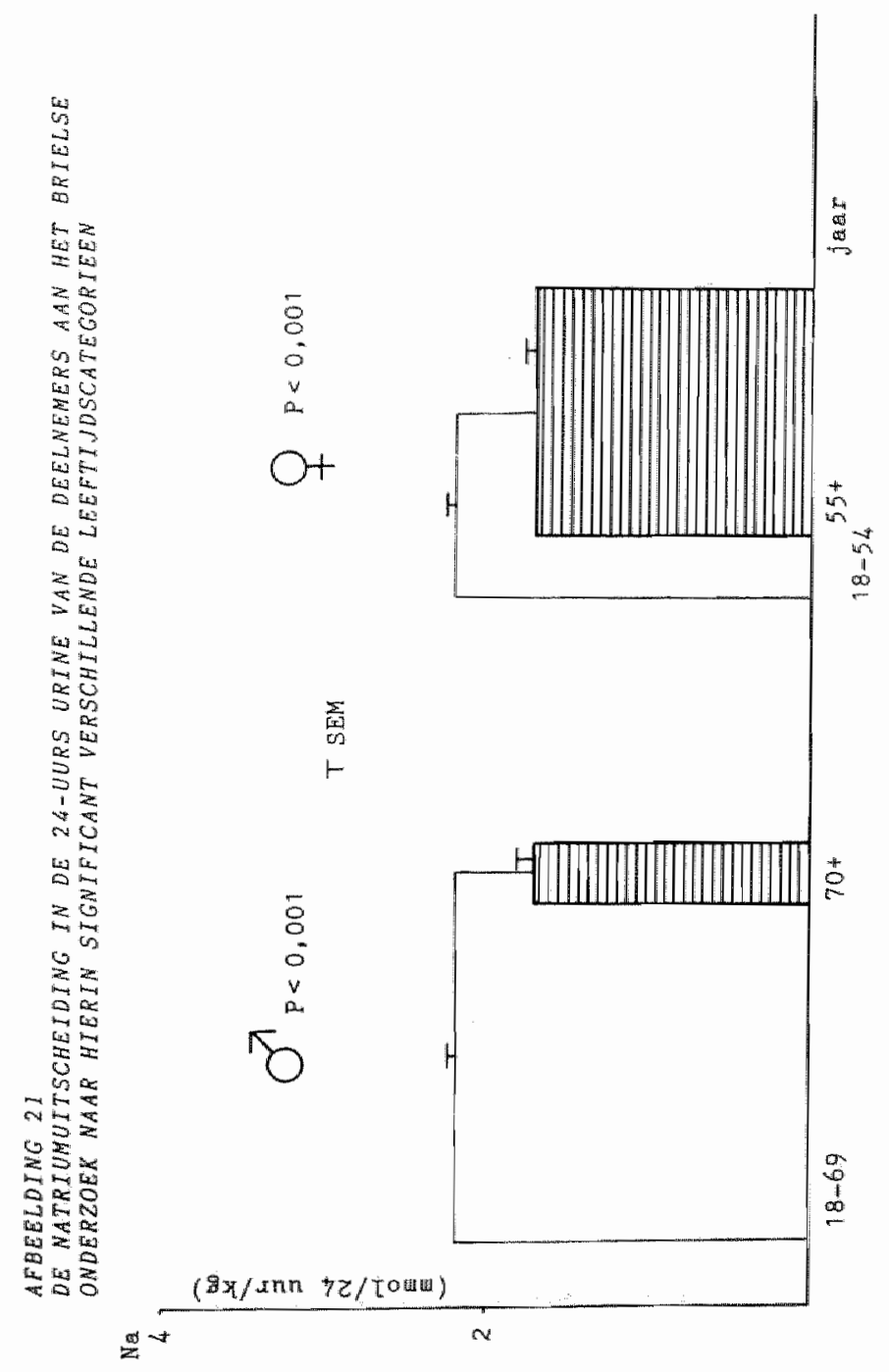




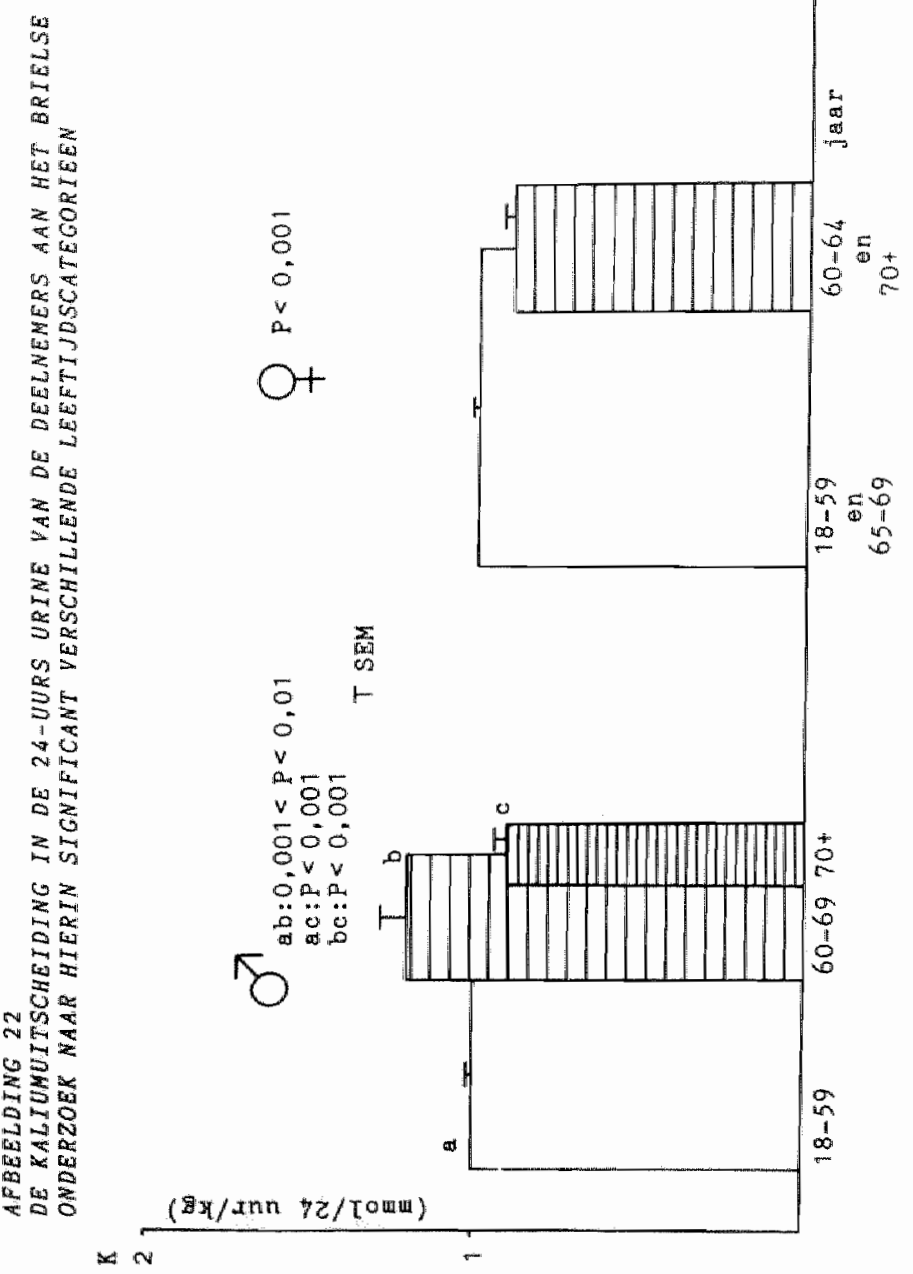




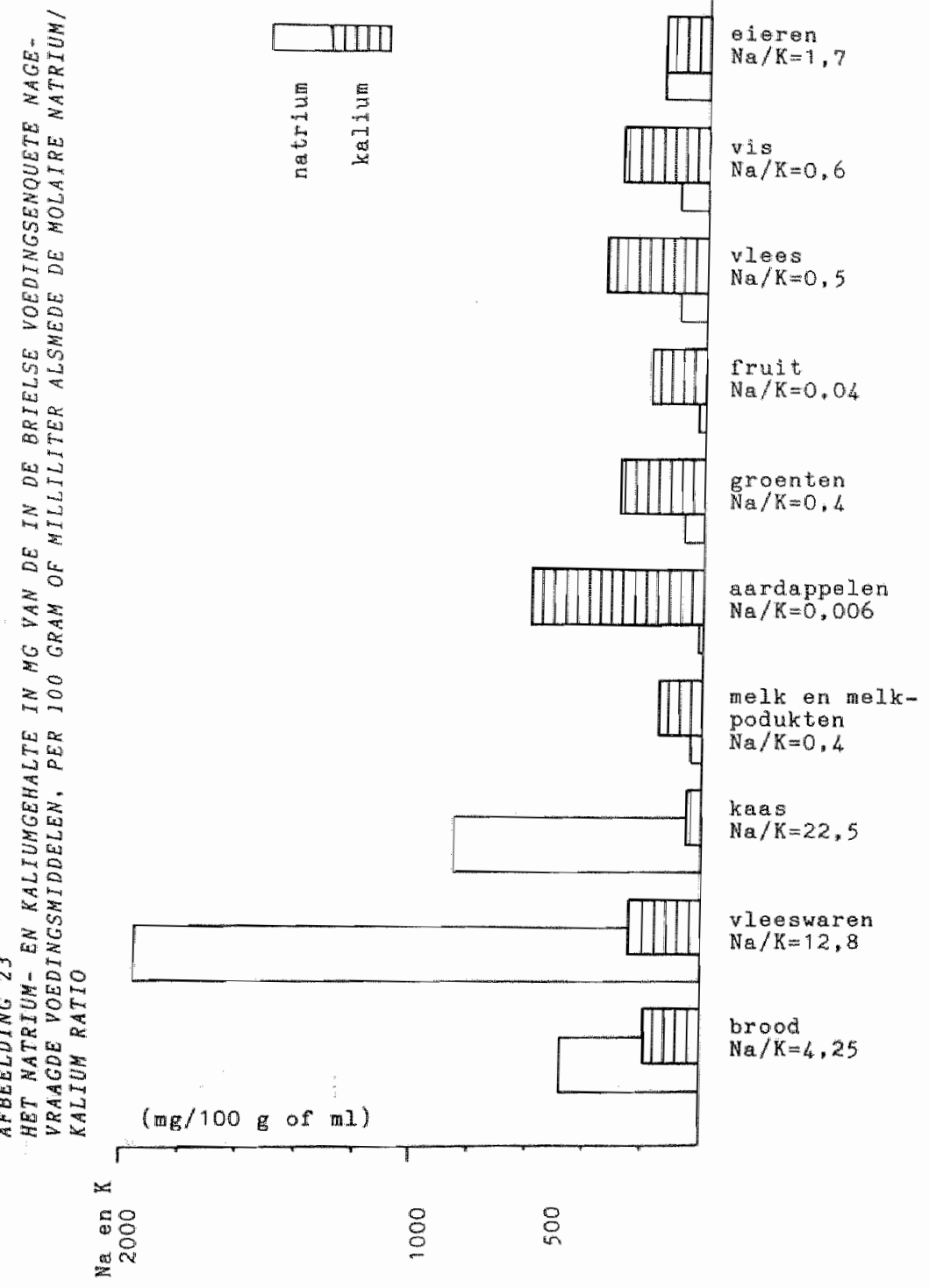



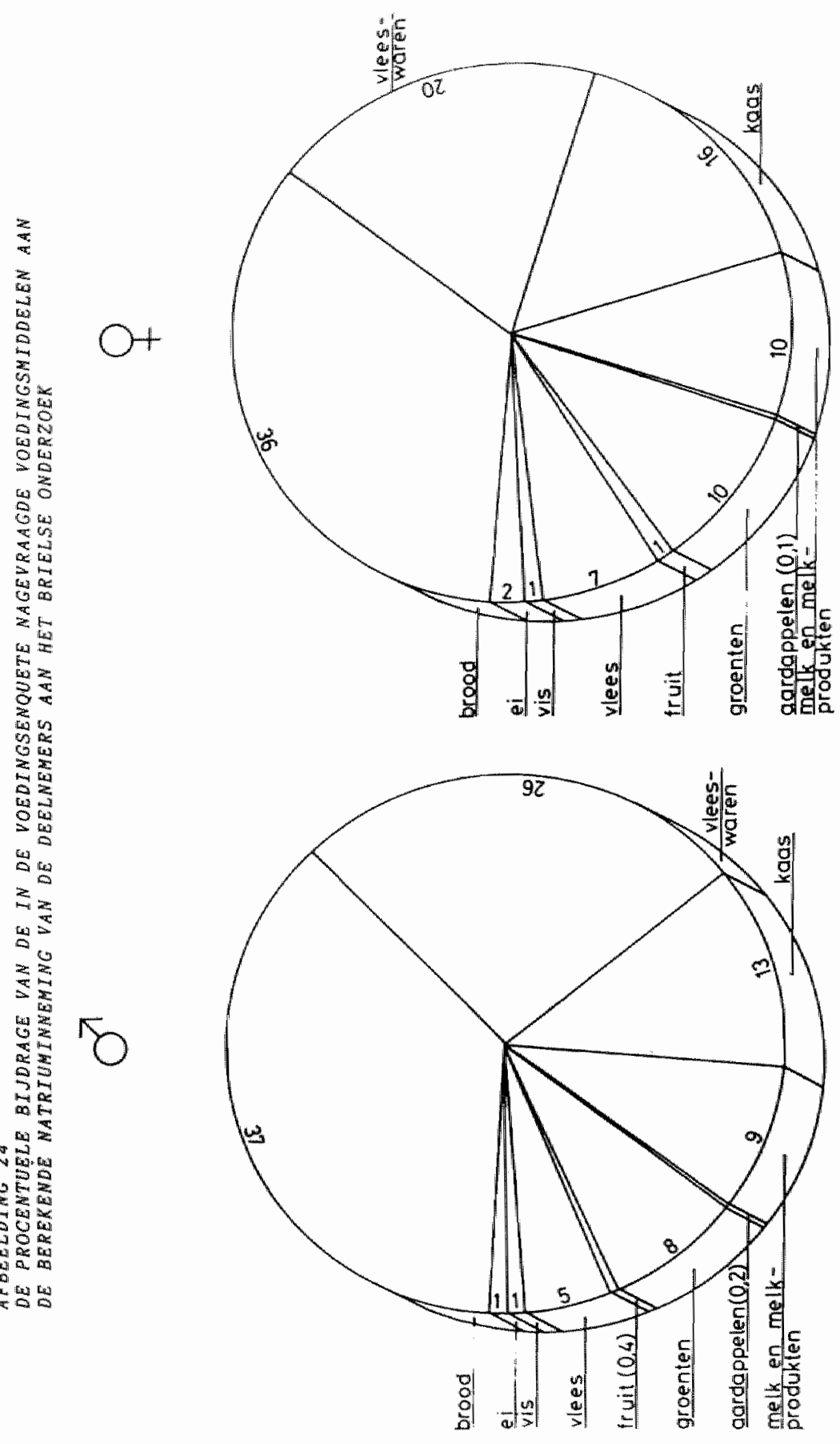

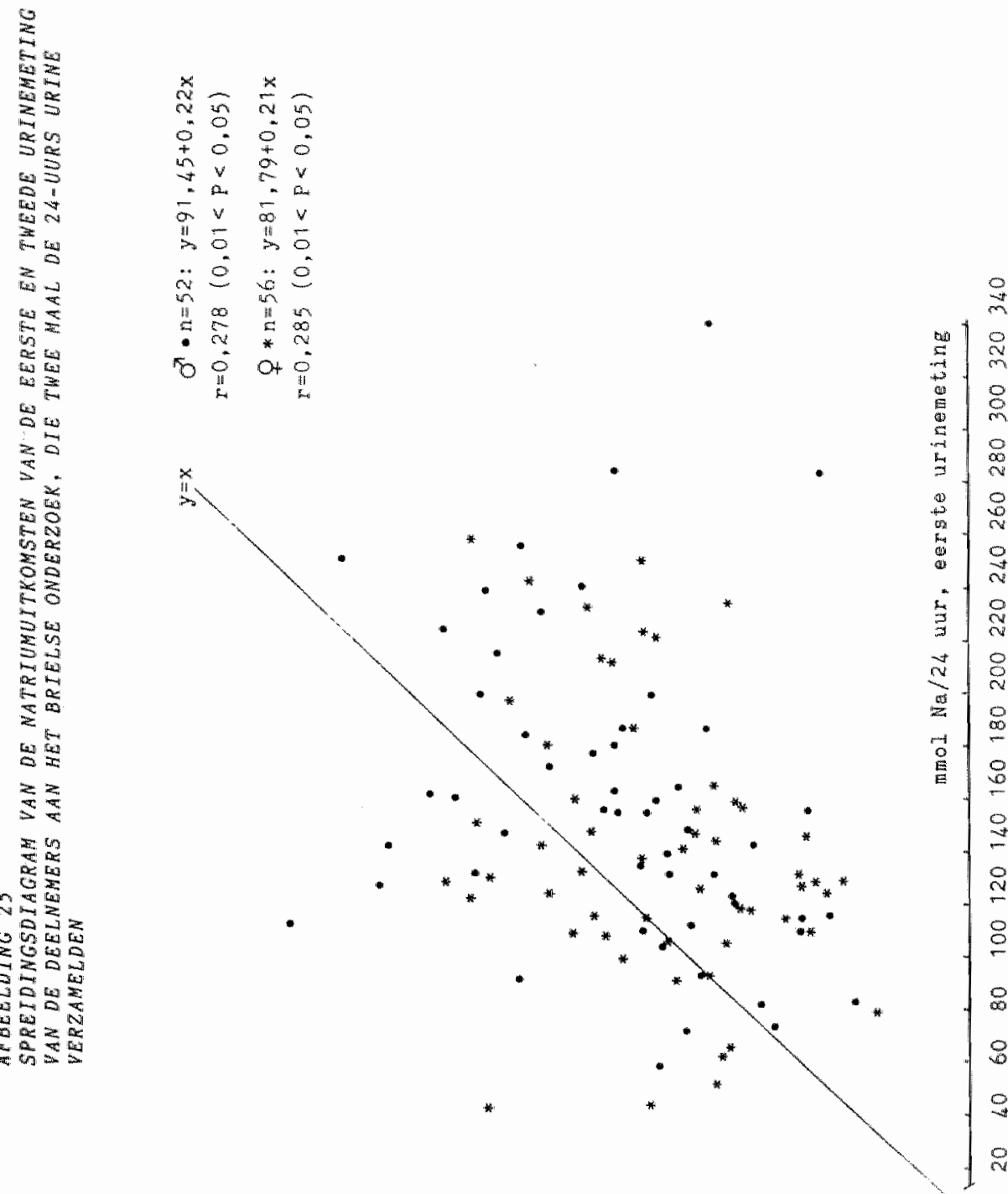

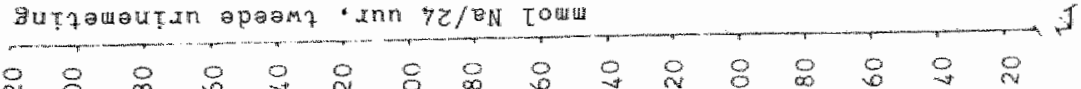

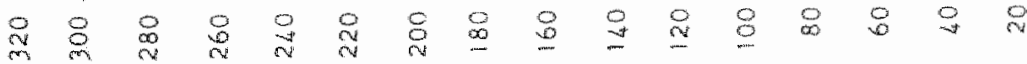




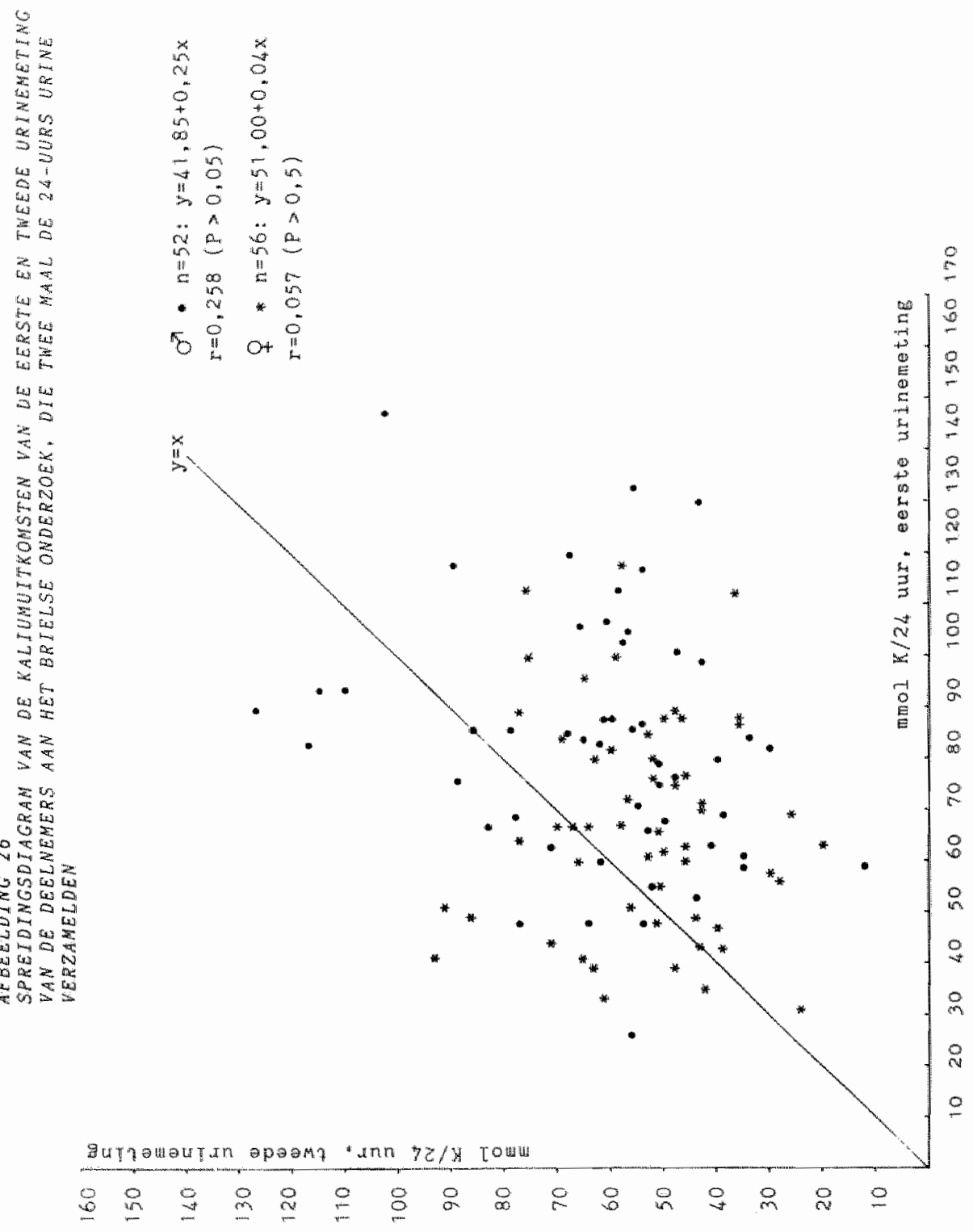


B IJ L A G EN 
hulsartsengroep brllelle portbula - $3230 \mathrm{AB}$ brillie

1. J. van binsbergen - oto 21

h. Kamma -076no-zosi4

m. a. korevar aranomes

b. p. ponsioen -01810.5223

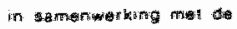

() Nederlandse Hartstichting

Geacthe Mevrow/heer,

17 angustus 1987

Ongetwifeld is het u bek nd dat hart-en ratziekten een bedreiging voor onze Eew voorkoming van deze andoeningen en zet zich in voor me onderzoek naar de oor zaken, de gevolgen en de behandeling ervan.

In samonwerking met de Mederindse Hawstichting wordt door ondergetekende een onderaek verricht det betrekking heeft op de opsporing van factorem die van itm vloed kunnen zijn op de hoagte van de blaeddruk. In verband met dit ondarzok doe ik thans een beroep op u. Ik zou u ramelijk willen verzoeken hieraan uw medewerking te verlenen.

Dit onderzoek vindt pilats in mijin wonhuis, Voorstrat 71. Een doktersassistenm te meet daar, naar keuze overdeg of "s ronds, uw lengte en uw bloeddruk, bepali uw gewicht en neemt een door u ingevalde vragenlijst met u doar. Verder wordt w gevraged gedurende 2 li wur op eem nader te bepalen dag de urine te veramelan, warover u uitwaerig instruotieg krijgt.

Ook indien w bloeddruk al wordt gecontroleerd of behandeld, wordt ww medewerketrie zeer op prije geateld.

Het onderzok is vanzelfsprekend geheel vrijblijvend on er zijn voor u geen kos-

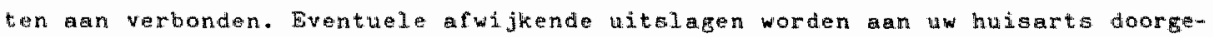
gevern.

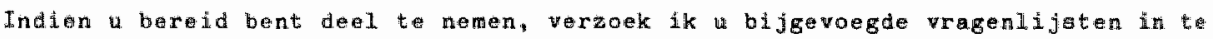
vilien en met mijn praktijkasistente, Hevrow sandford, voor het korte anderzadi

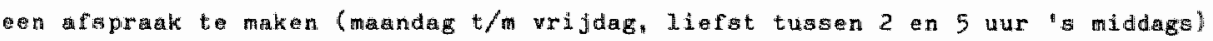
via tele foonnumer 2155 of aan de balite.

Bij roorbat we vel dank voor uw zo noodzakelijke medewerking.

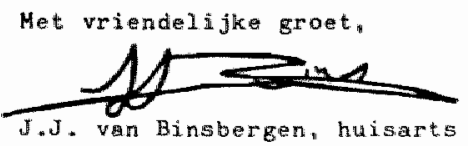

Bijgesloten: J vagerijater 
hullsartsengroep brlelle

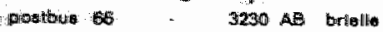

f. 1. van binsbergen - 01810-21:55

h. kamma

.0181042054

m. s. Korevaer

b. p. ponstoen
$-01810-3763$

.01910 .5223

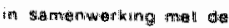

- Nederlandse

Hartstichting

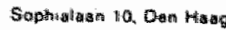

Drielle, oktober 1981

Geachce Mevroum/Heer,

Enige tijd geleden ontwing a een witnodiging ara dael te rutuen an een onderzoek op het gebied van verhoogde bloeddruk.

Woor her geval u wel had willen deelnemen mat datroe niet in de gelegenheid was, deel ik the dat dit alsnog mogelijk is. U bent dus wan harte welkom.

Wilt u dian zo wriendelijk $z i j n$ een afspraak te maken met mijn praktijkassistente (maamag $\mathrm{t} / \mathrm{m}$ vrijog, liefst tussen 2 en 5 unr 's middags' via telefoomumer 2155 of an de balie.

U kunt een en ander nog eens doorlezen in de bijgevoegde witnodigingsbrief.

Het onderzok is nacuurlijk geheel vrijblijvend en er zijn voor u geen kosten aran verbonden.

Dok als u besluit niet me te doen, zou ik dat graag van wernemen.

Bij voorbat veel dark.

Mate vriendelijke groet.

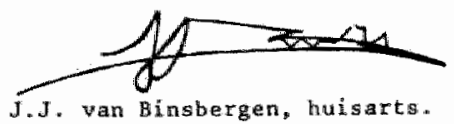

M. Mochten de u reeds eerder toegzonden formuliezen nite mar in uw bezit zijn, wite u dit dan alstublieft doorgeven bij het raken van een afspak? 
hulsartsengroep brlelle

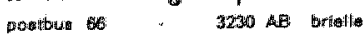
j. J. wan binsbergen - viara-21s5 h. Kamma - o1 $810-2054$ m. s. korevaar 01810.3783 b. p. pongioen - 018005223

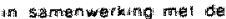

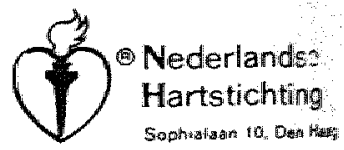

\section{INFORATIE DETREFFENDE DE 24 -WURS URINE VERZAHELING}

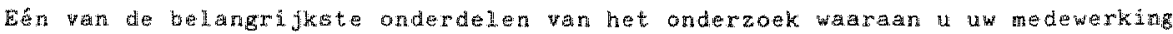

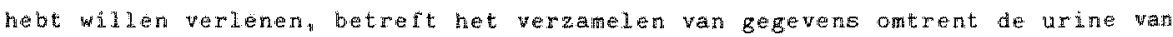
en feroot antal personen.

Voor hut welsiggen van het onderzoek verzoek ik u onderstaande richtlijnen stipt ap te voligen.

HEI VERZAMELEN VAR DE ZU-UURS URINE:

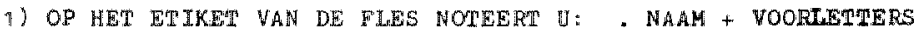

- GEBOORTEDATUM

- ADRES + POSTCODE

- DAG * DATUM URINEVERZAMELTNG

2) HET WERZAMELEN VAM DE URINE VANGW AAN OM 12 UUR 5 NACHTS EN ETMDIGT ON 12 WUR "S NACHTS DE WOLGENDE DAG.

Toelichting: Indien men wór 12 uur 's nachts már bed gat, dient men do blass te ledigen ir het toilet. Gedurende de nacht en de deg die darop volgen wordt alle urine rechtstreeks in de 1 les verzameld. Vóar men zich de volgende nacht te bed beger fo dient men goed uit te plassen in de fles. Indien men ma 12 um "g nachts mar bed gat wordt alle uring werzaled vanaf dat tijdstip tot weer do volgende dag 12 war "s nachts.

3) OOK DE URINE DIE VOOR, TIJDENS OF NA DE ONTLASTING WORDT GELOOSD DIENT IIE WORDEN OPGEWAMGFN.

4) HET VOCHI DAT IN DR FLES ZIT MOET ERIN BLIUNEN. HET DIENT WOOR DE HOUDBAARHEID EN IS BIJTEND ZOLANG HET NIET MER URINE VERDUND IS.

5) DE TRECHTER DIE TIJDENS DE URINEVERZAMELING WORDT GEBRUIKT, DIENT MIET

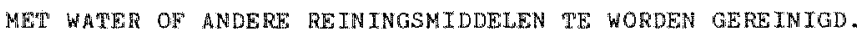


6) DE FLES STEEDS RECHTOP BEWAREN OP FEN KOELE PLATS.

7) GELIEVE DE FLES TERUG TE BRENGEN OP DE AFGESPROKEN TIJD.

Wet weel dank voor w wedekerking,

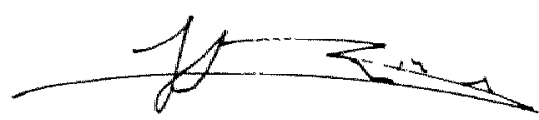

J.J. Wan Birsbergen, huisarts 
hulsartsengroep brielle posithas $3230 A B$ borlalls

sn sartignarking mett de

1. J. wan binsbergen - 01an0.2155

h. kanma

$-010410.2054$

m. s. korevar

- $01610-3763$

b. p. ponsioen

$.01010-5223$

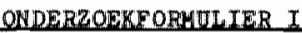

1. ALGEMEEN
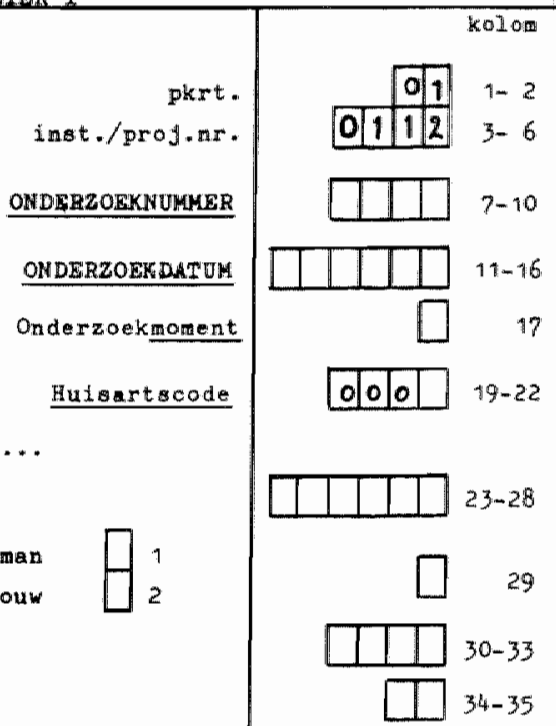

. Nam + voorlettori $\ldots \ldots \ldots \ldots \ldots \ldots \ldots \ldots \ldots \ldots$

Hutartsoods

- Geboortediatum

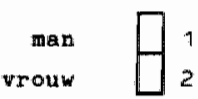

- Postcade (alléén de cijfers 1)

- Reserve (Temperatur ?)

2. ANT ROPOMETRIE

* Gewleht

- Lengte

- Kniebreedten:

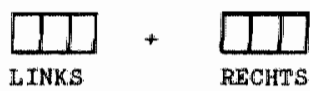

3. BLOEDDRUK
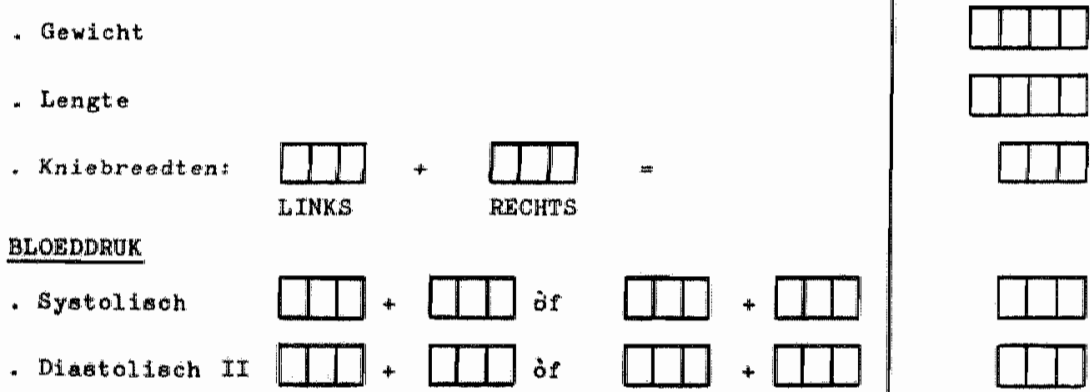

\section{Pollofrequentio}




\section{BIOCHEMIE URINE}

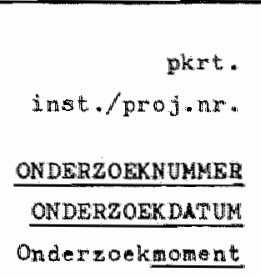

1. Iaboratorium

- Natrium/24 uar

- Kalium/24 uur

- Creatinine/24 uur

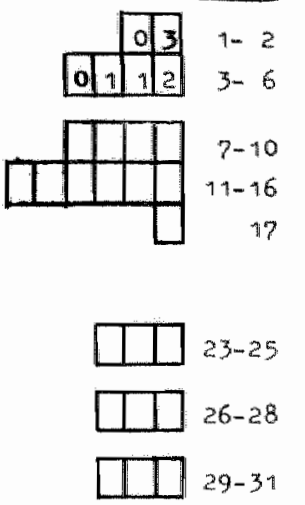

2. Combur 8 Test

- Nitriet

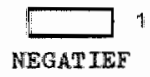

- pH-waarde
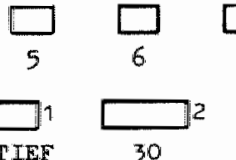

- Eiwit
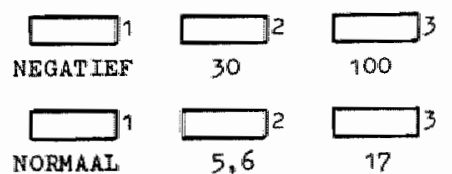

- Glucose NORMAAL

- Ketonen
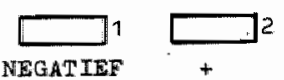

- Urobilinogen ( $\mu$ moll/1)

$\square$ NORMAAL 17
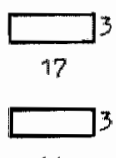

t+

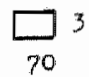

Bilirubine

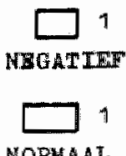

- Brythrocyten NORMALI
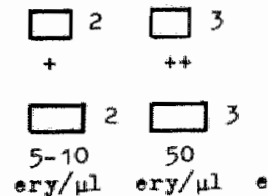

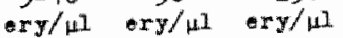

- Haemoglobine
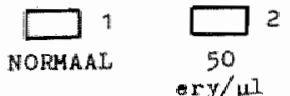

3. URTNEWERZAMELTNG

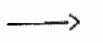

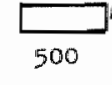

$\operatorname{mg} / d 1$
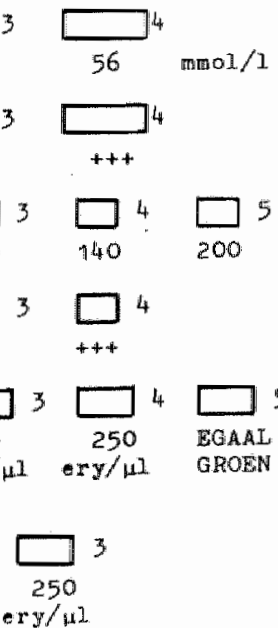

$$
\text { erg/ul }
$$

3

כ

$\square 60$

$\square 61$

D 62

$\square \quad 63$

D 64

D 65

प 66

D 67

w 68 
Wit a de volgende vrager beartwoorden door in da darvoor bertemde hokjea en krus je te zeten?

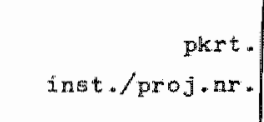

ONDERZOEKNUMMER

ONDERZOEKDATTM

Oryatergotoment

1. Mag :

2. Vongnamen:

3. Geboottedatum:

4. Ges Lacht:

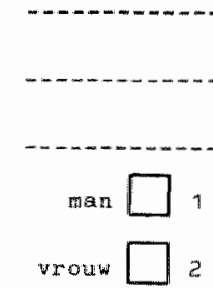

5. Adres + Postcode:

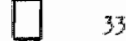

6. Tele foonnumer:

7. Nagm van uw hiseres:

8. Hent u:
$1 \square$ ongehused
2 ए gehusd
$3 \square$ ongehwod

$4 \square$ weduwe/hedumaar

$5 \square$ gescheiden

9. Hoevell kinderan hobt u 
11. Heeft w ooit pijn in de hartstreek gehad?

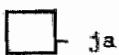

00

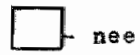

Zo ja, op welke leertijd ? jarige leeftijd.

12. Heeft u ooit een hartinfarct gehad?

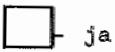

00

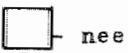

Zo ja, op welke leeftijd?

jarige deeftijd.
DEZE: ROLOM NIET

INWTILLEN A. I.B.

[D $37-38$

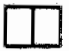
$39-40$ jarige leeftijd.

13. Heeft w oalt een hersenbloeding of beroerte gehad

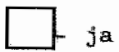

$\infty \square$ nee

Zo ja, op welke leeftijd ?

14. Heeft u (ooit) hoge biaeddruk (gehad)?

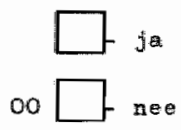

20 ja, op welke leeftijd begon dit? Jarige leeftijd.

15. Inijdt u of heeft u geleden aan :

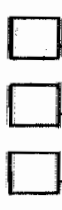

veatwernauwing in de benen

ondegelmatige hartslag.

kortademigheid bij inspanning

sulkerzikete

nier- of blasaandoeningen

dikke enkels of voetem

16. Gebruikt u medieignen?

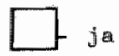

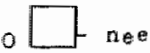

$\square 41-42$

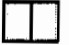

$43-4.4$

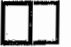

$4.5-46$ 
17. Volgt u een dieet?
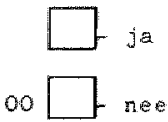

Zo ja, welk dieet?

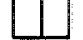

Volgt u dit dieet op : $1 \square$ voorschrift huisarts

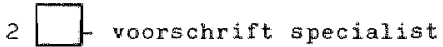

18. Rookt $u$ ?

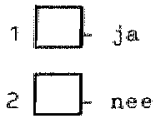

Indien u rookt:

- hoeveel pakjes sigaretten per week"

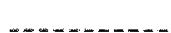

- hoveel pakjes shag per week ?

- hoevel sigaren/sigaartjes per week ?

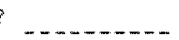

- hoovel zakjeg pijptabak per week ?

19. Indien ww gewicht na uw $25^{\circ}$ jaar is toegenomen, kunt u dan angeven met hoeveel kilogram?

30. Vyag voor wrouwen:

- Gebruikt u op dit moment de "pil"? $1 \square$, ja $2 \square$ nee of:

- Heeft u vroeger de "pil" gebruikt $3 \square$ ja $4 \square$ nee

- Indien u na of wrouger de "piz" gebruikted, hoe lang doek u dit can/ deed u dit ? jaax. 
2. Hebben raste familiedaden (grootanders, ouders, broers of whtors) de wolgerde a dekten gehar

Pijn in de haxtotreek. Wie" pakt.

Vaatverrauming in écén

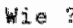

Hoge bloedaruk. Wie?

Herserbloeding of beraerte. Wie?

Suikerziekte. Wie?

Magawer. Wie?

Maagkanker. Win?

Nierandoeningen. Wie $\gamma$

Hartimfarct. $\quad$ o ga, whe en op welke lettijd?

\section{ALEEEN VOOR VROUWEN !}

- Neeft u kinderen?

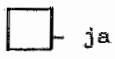

00

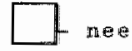

Zo Ja, hoeveel?

kinderen. of beide benen.

Dhe

N I IN INVI

LES A.U.B.

$12+2$

D 66

ए 67

$\square 68$

$\square \quad 6$

$\square 20$

D 74

D 72

प 23

74

$75-76$

$77-78$

- Had u tojders de zwirgerschap(pen) ent

1

montarm diect (dat wil zeggen: bij de bereiding var maaltijen fét zout toevoegen)

2

zout loos dìet ldus nlet lleen gén zout toevore gen bij de berelding mar tewens alidem toegeataan het gebruik van zoutloze producten zaals: zoutloog brood onz.)

W 79

$3 \square$ ander aoort dieet dan bovengtaand.

4. $\square$ geen dieet

- Indien u mu zwanger bent, wanmer was uw latate mens thutio" manden geleden.

6


L. S.,

Dit vragenformuller bevat 8 vragen: 4 vragen zijn bestemd om beantwoord te worden door de vrouweilike deelnemers an dit onderzole en 4 wragen ajn bestemd voor de mannelijke deelnertion.

Indien $u$ gehuwd bent, langdurig samenwoont of weduwefwedunaar bent, wordt u verzocht zowell de vragen voor de man als roor de vrouw te beantworden.

Indien a angehuwd of gescheiden bent en niet samenwoon kunt u uiteramd volotan met de vragen betreffende uzelf to beantwoorden.

V wordt verwooht de vragen te beantwoorden door in de darroor bestende hokjac en kruinge to geten.

Bij roorbat hartelifik dank. 
DEZE KOLOM NTET

MUVUILLEN A.U.B.

pert.

1. Wat is te hoogste oplejding dic u genoten hebt?

1

lager orderwijo + tontule cursussen

2

Iager besoeponderwis t evertuele cursussen (bifwoorbeeld: moderakschool, huishoudschool, INAS, LEAO, IUTS)

3

(m) ulo of mavo t eventuele cursussen

4

middelbas bexoepsonderwi.js

(bijwoorbuld: kleuterleidater, verplegster, LO-akten, laborant, analist 1 of 2$)$

5

VHMO (bijv.: HBS, atheneum, Gymasiun)

6

moger beroepsonderwijs

(bijv.: Hus, MO-apleidingen, pedagogische acadenj, diëtst, analist 3 of 4 )

$7 \square$ universiteit of hogeschaal

Heet $u$ deze opleiding roltoofd?

a $\square$ wel woltooid

b niet roltooid

D?

c $\square$ ben ex mee berig

2. Oefent b butenshads een beroep Lit?

7
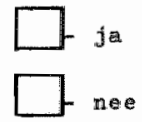

Zo nee, wat is dan voor u wan taepeising?

2

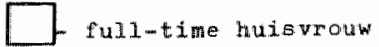

3

L sepensioneerd

4it

[- tijdelijk geen werkkring (wW, Whv, RW)

5

anders 


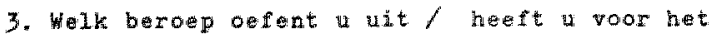
latat ulegoofend?

DEZE KOLOM REIET INVTLLER A.U. B.,

10.8 4. 2

? $39-40$

(indien u ambtenar bent ook graag un rang/functie)

4. In wat voor eoort bedrijt werkt u/ werkte u?

Wat is daar uw functie?

1

L Leidinggevend (ower personen)

$2 \square$ niet-leidinggevend

Bent u als zelfstandige werkzatr?

1

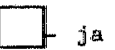

2

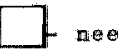

Indten $u$ en eigen agrarisch bedrigf heeft :

- is dat dan een $\square$ akkerbouwbedriff
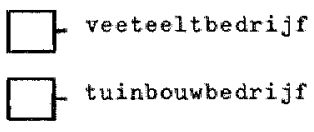

ए gemengd bedrijf

- hoo groot is ww bedrijf/hoevelel we bealt u? 
DERE KOH OH NIEM INUTLLEN A.U.B.

5. Wat is de hoogste opleiding die u senoten hebt

*<smiles>[CH-]1CCC1</smiles>
lager anderwijs + eventueje cursussen

2<smiles>C1CCC1</smiles>
lager beropsonderwijs + ventuelle cursussen (bijvoorbeeld: wodevakschool, huishoudichool, INAS, LEAO, LIS)

3<smiles>[CH-]1CCC1</smiles>
(m) ulo of mavo + eventuele cursussen

4<smiles>C1C[I-]C1</smiles>

iddelbar beroepsonderwi jo

(bijtoorbeeld: Kleuterejuster, vorpleegsier. Lo-akten. laborant, arajist 1 of 2 )

5

WHMO (bifv.: HBS, athereum, gymnatum)

6

hoger beroepsonderwijs

Cbijv.: HTS, MO-opleidingen, pedagogische acadenie, diëtist, analist 3 of 4 )

7

universiteit of hogeschool

Heft u deze opleiding roltooid?

a $\square$ wel roltooid

i niet voltooid

c 7 wen er mee bezig

6. Oefent u buitembuis een beroep uit?

1

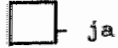

$\square$ ne

Zo nee, wet dis dan voor u van toppasing?

3 gepensioneerd

4.

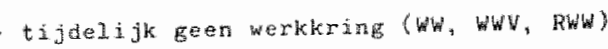


DEZE ROLOM MIET INWULLEN A.U.B.

7. Welk beroep oefent u uit/ heelt w voor het liatet uitgogend?

(indien u ambtenaar bent ook graag uw rang/functie)

8. In wat voor soort bedrijf werkt u/ werkte a?

Wat is daar uw functio?

$1 \square$ Leidjmgevend Cover personen

$2[$ niet-1eiding gevend

Bent $u$ al zelistandige werkgan?

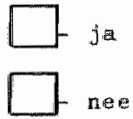

Indien u een eigen agrarisch bedrijf heert :

- is dat dan en $\square$ akkerbouwbedrijr

W veateeltbedrijr

प tuinbouwbedrijt

T gemengd bedrj,jf

- hoe groot is uw bedrijl/hoeveel vee bezit u? 


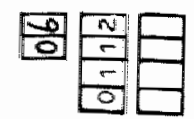

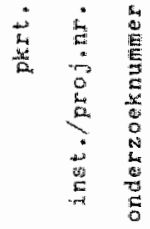
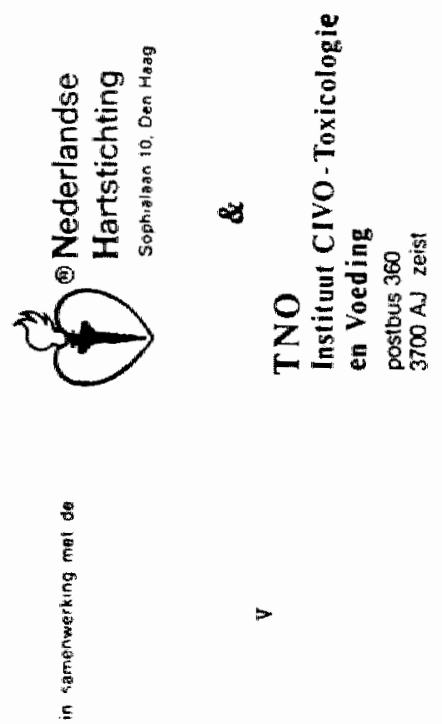

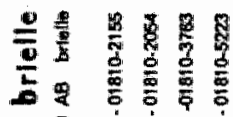

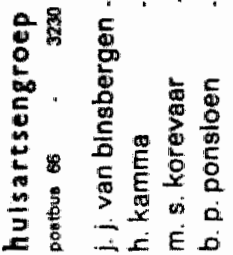

㱐

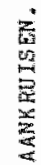

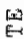

$O$

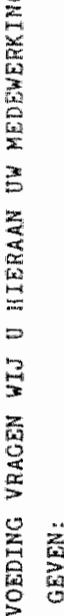

然

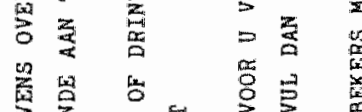

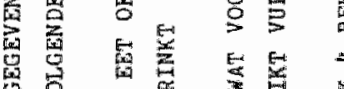

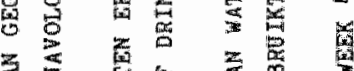

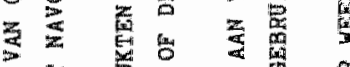

$\rightarrow 4$ a

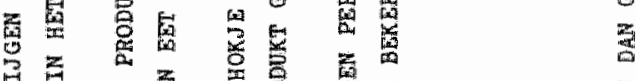

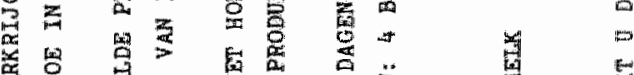

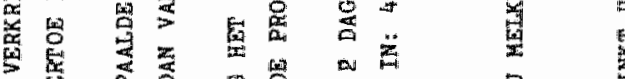

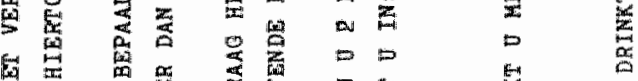

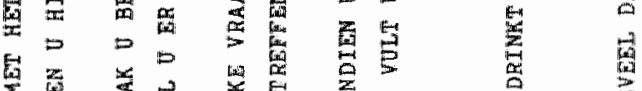

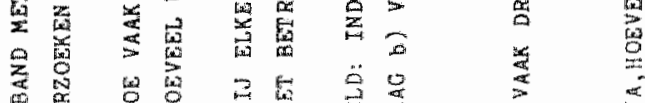

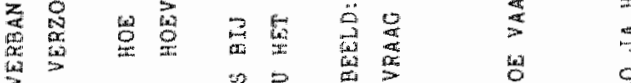

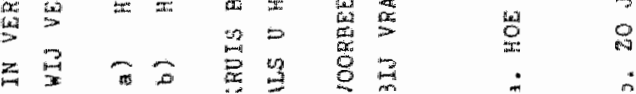




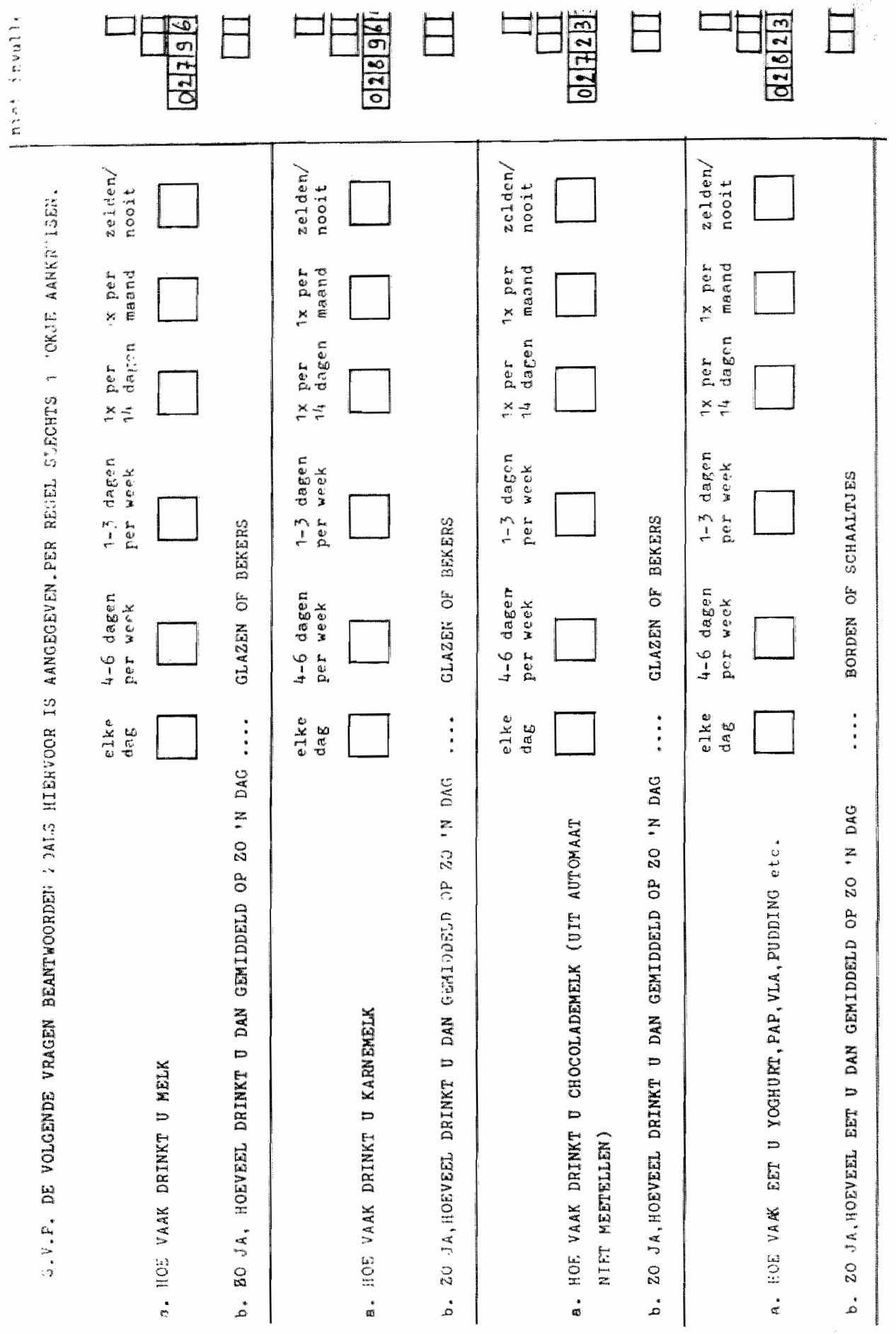




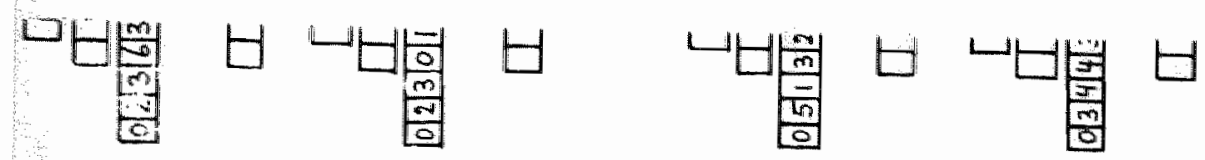

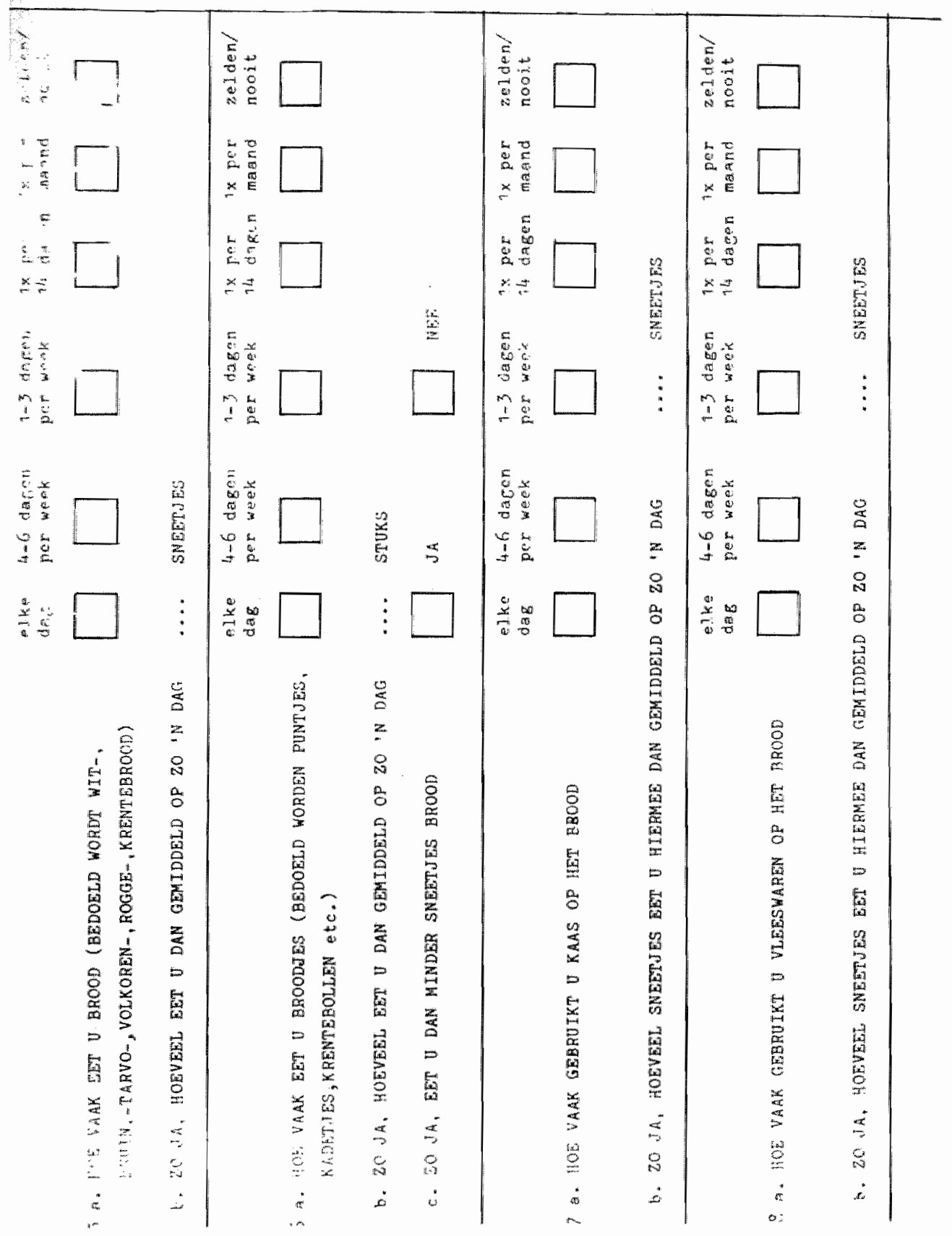



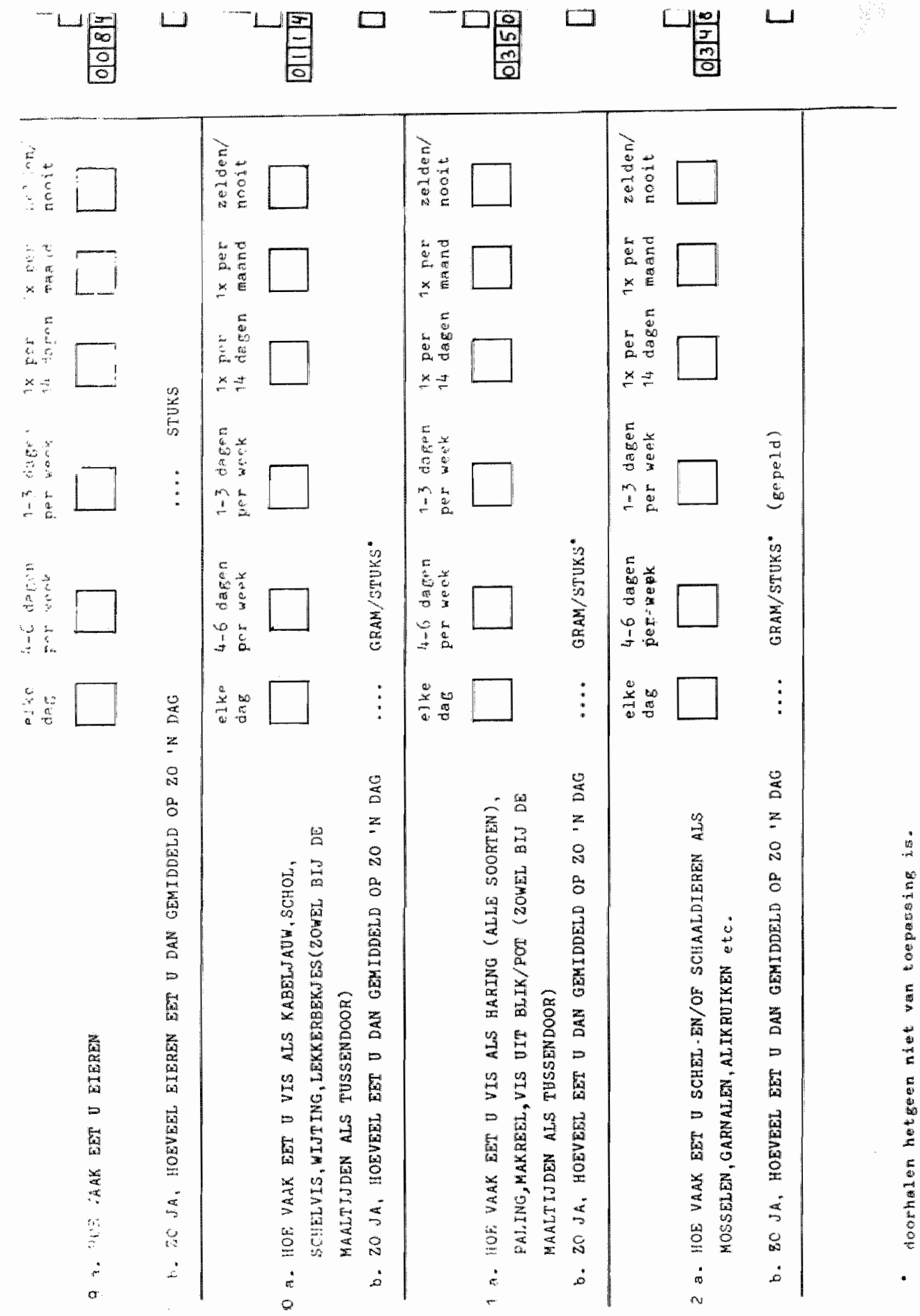

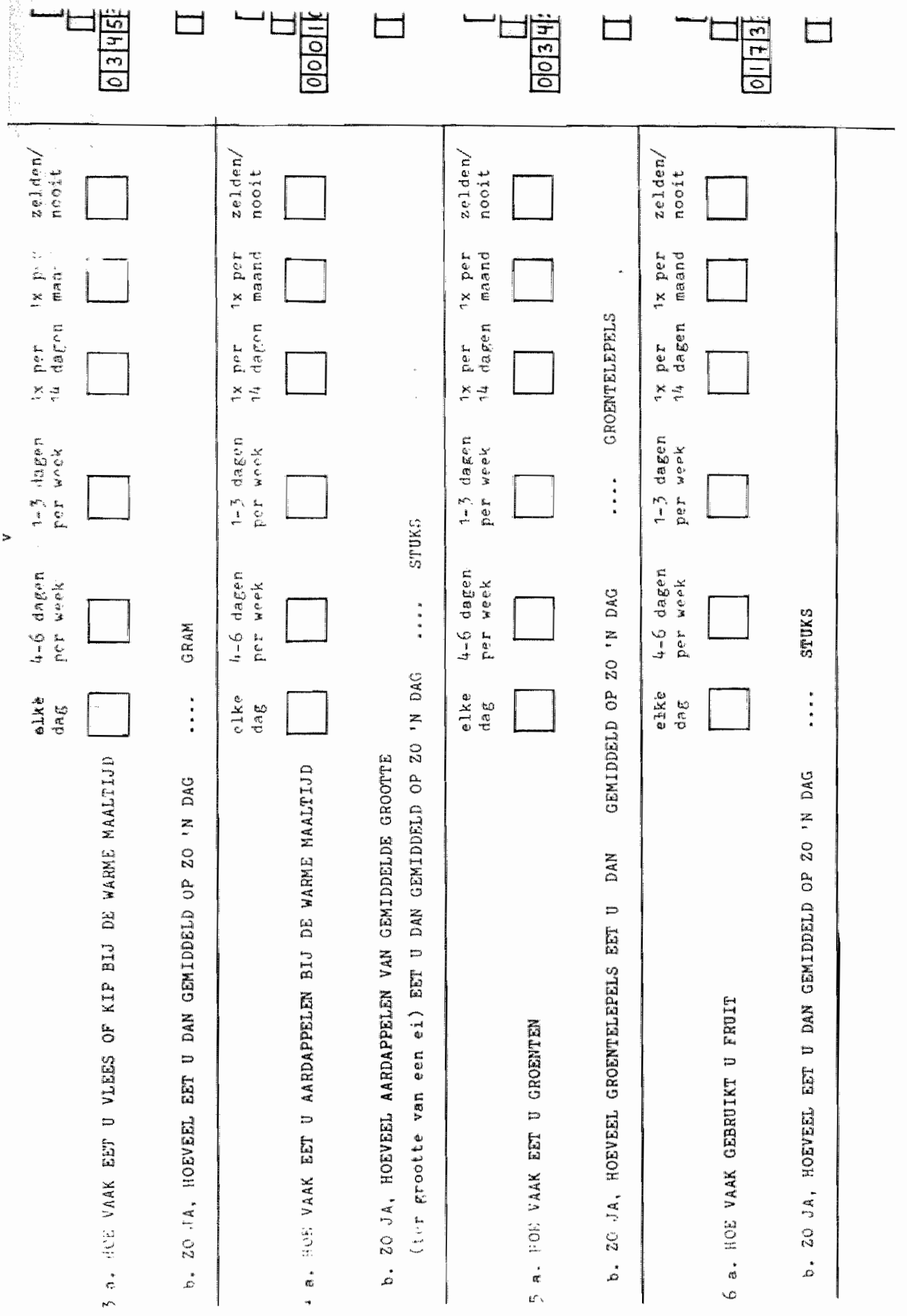


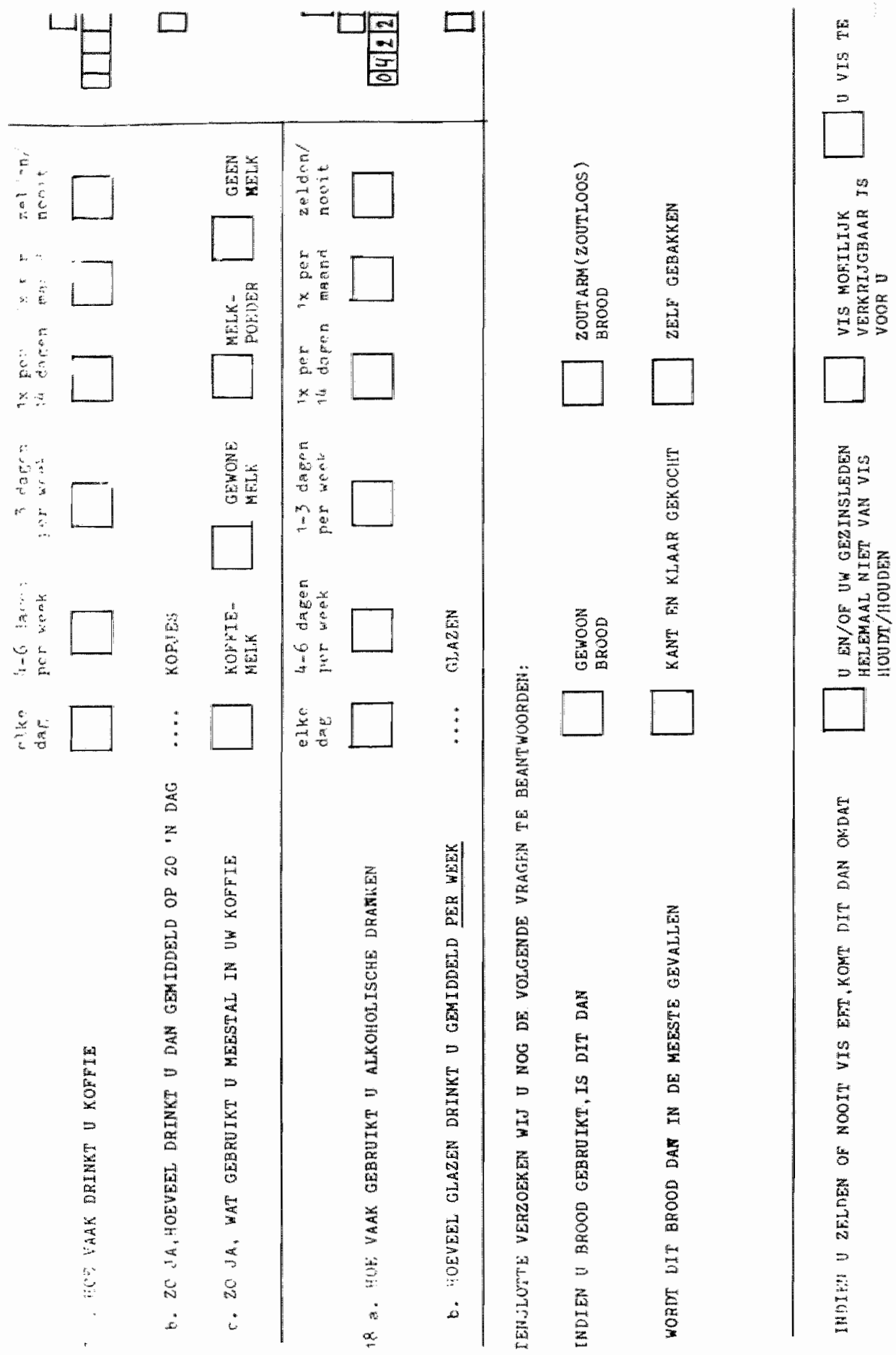


BOTLEK - RANOSTAD-EDITIES - 17 SEPTEMBER 1891

Bekendmaking

Voor thet ondernoek camen mot do

Nederlandes

Hartstichting

kunten do

aringachothomen

perionen zich nog stoeds armmeldon.

J. J. W. Pluderen

neilusit: 


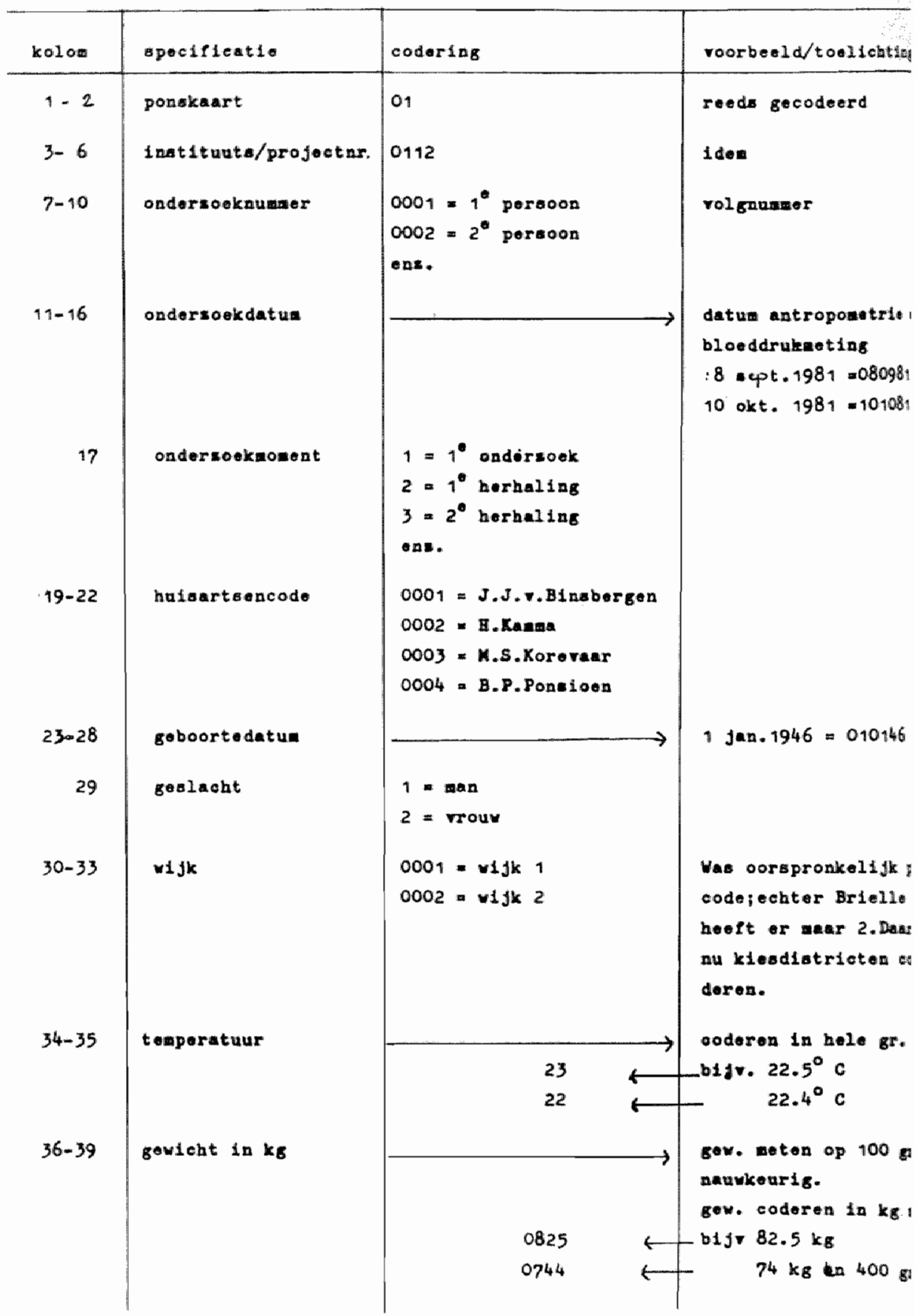




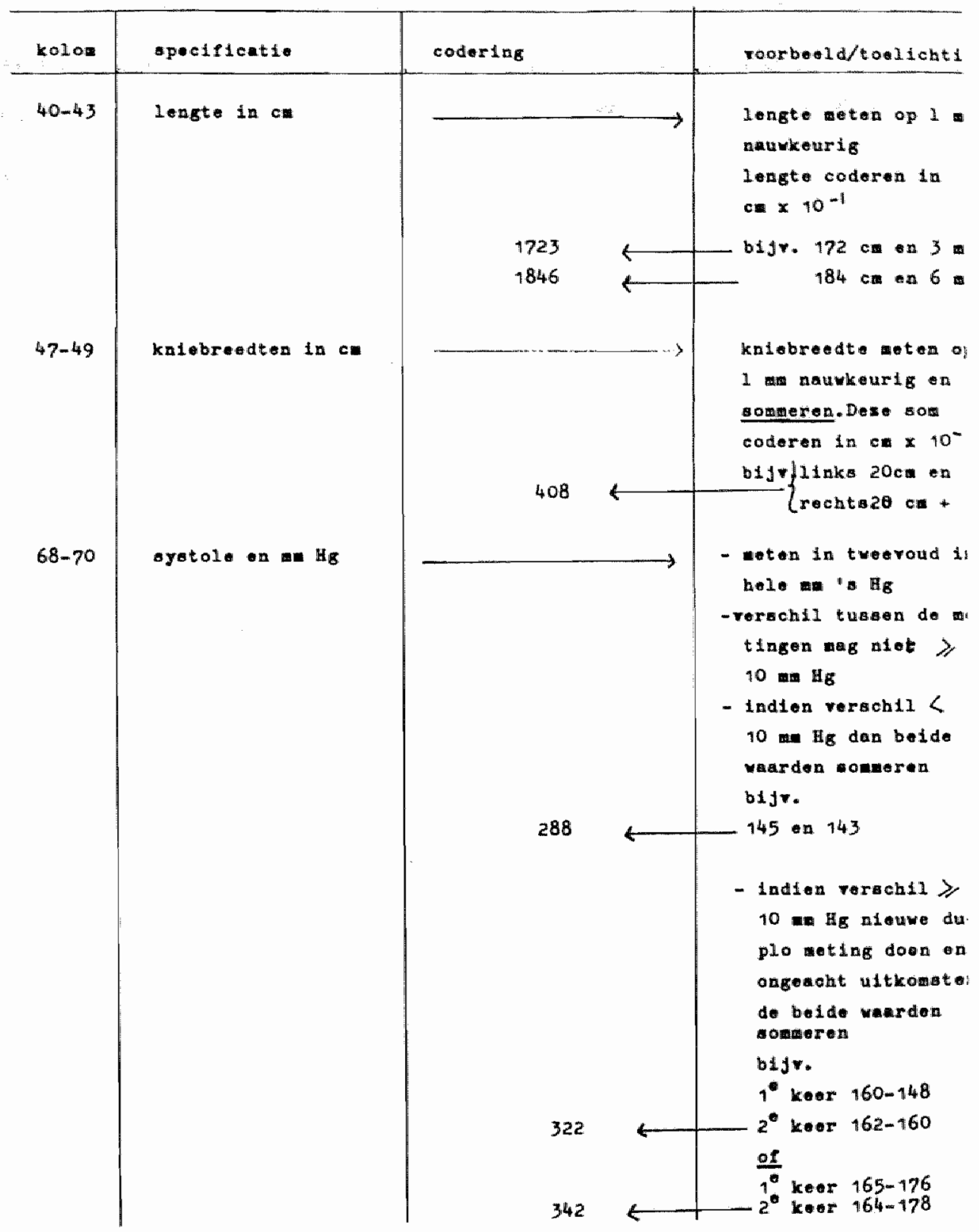




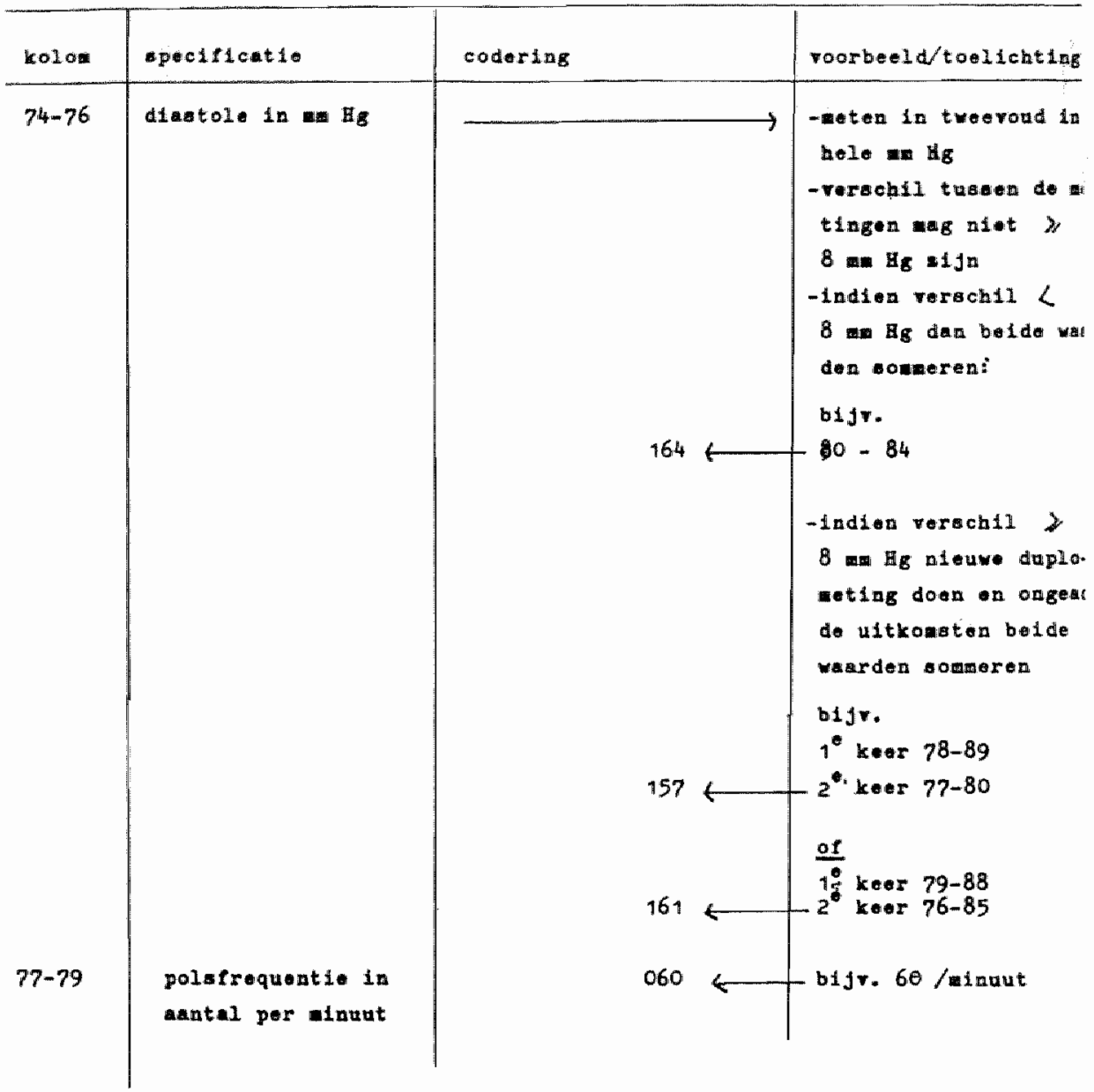


CODERIMG ONDERZOEKONWULIER II

\begin{tabular}{|c|c|c|c|}
\hline Kolo & epacilicatie & codering & roorboeld $/$ toellethting \\
\hline $1-2$ & ponakeart & 0.3 & reede gecodeerd \\
\hline $3=6$ & Inst Ituutes/projectar. & 0112 & Idea \\
\hline $7-10$ & onderzoekntumear & & ye codering fork. I \\
\hline $11-16$ & ondersoekdatum & & datu urigererseneling \\
\hline 17 & ondersoekwoment & & w1 codering form. I \\
\hline 22 & dag urinorersaneling & $\begin{array}{l}1=\text { mandag } \\
2=\text { dinodeg } \\
3=\text { voenodag } \\
4=\text { donderdas } \\
5=\text { mrljdas } \\
6=\text { stordag } \\
7=\text { sondag }\end{array}$ & \\
\hline
\end{tabular}

do rest wan het foraulior oproukt roor alich 


\begin{tabular}{|c|c|c|}
\hline Lolog & ovechridring & coderimg \\
\hline $7-10$ & 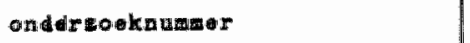 & wolgnumer, zelf to te kennem \\
\hline $41-16$ & opderzookdat win & $\begin{array}{l}\text { wolo: } 11-12 \text { datua } \\
13-14 \text { wand } \\
15-16 \text { jans }\end{array}$ \\
\hline 17 & onderzokkonont & 1 : I ket \\
\hline $2 y-28$ & geoortidatail & $\begin{aligned} \text { kolom } & 23-24 \text { datum } \\
& 25-26 \text { mand } \\
& 27-28 \text { jamr }\end{aligned}$ \\
\hline 29 & gotacht & $\begin{array}{l}1=\operatorname{man} \\
2=\text { rroux }\end{array}$ \\
\hline 33 & aree a posteode & Wlynumer inrullen \\
\hline 34 & burgeI1Jke stant & 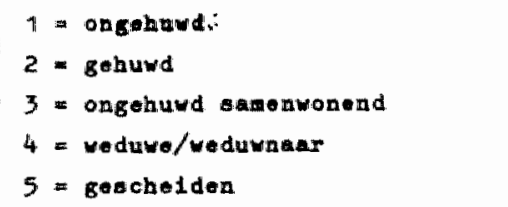 \\
\hline $35-36$ & antal kinderen & $\begin{array}{l}00=8 \cdot \pi \\
.-\operatorname{arctal} \text { inrullen }\end{array}$ \\
\hline $37-38$ & doorgenalkto $p \perp j n$ in bartoteck & $\begin{array}{l}00=\text { nee } \\
\ldots=\text { Ja, laeftifd Iaralien }\end{array}$ \\
\hline $39-40$ & doorgonabt hartinfaret & 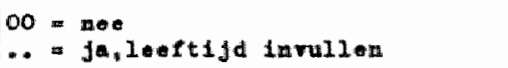 \\
\hline $41-42$ & $\begin{array}{l}\text { divargemakte hersembioedind } \\
\text { beroerte }\end{array}$ & $\begin{array}{l}00=\text { nea } \\
\ldots=j a, 1 \text { eeftidd Iarulles }\end{array}$ \\
\hline $43-44$ & hogo blooddrok & $\begin{array}{l}00 \text { - nee } \\
\ldots \text { - leeftijd neratio conataterims }\end{array}$ \\
\hline
\end{tabular}




\begin{tabular}{|c|c|c|}
\hline kolom & gmachrifying & coderins \\
\hline $45-46$ & Ioktoprewal ontio & 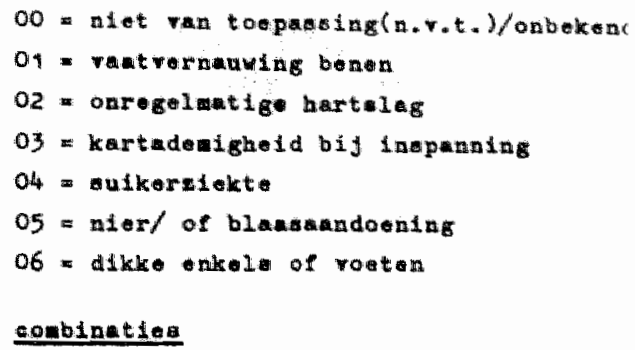 \\
\hline
\end{tabular}

$12=04+02$

$13=01+03$

$14=01+04$

$15=01+05$

$16=01+06$

$31=03+04$

$32=03+05$

$33=03+06$

$60=01+02+03$

$61=01+02+04$

$62=01+02+05$

$63=01+02+06$

$64=01+03+04$

$65=01+03+05$

$66=01+03+06$

$67=01+04+05$

$68=01+04+06$

$69=01+05+06$

$80=01+02+03+04$

$81=01+02+03+05$

$82=01+02+03+06$

$83=02+03+04+05$

$84=02+03+04+06$

$85=03+04+05+06$

$86=01+02+03+04+05$

$87=09+02+03+04+06$

$88=02+03+04+05+06$

$89=01+02+03+04+05+06$ 


\begin{tabular}{|c|c|c|}
\hline 20102 & gimebre & eoder $\ln 2$ \\
\hline 47 & sadleljngabratk & 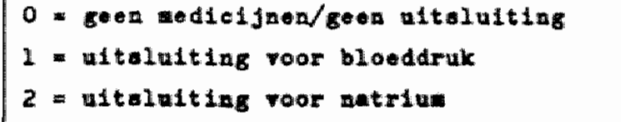 \\
\hline $48-49$ & gebrate ran dieet & 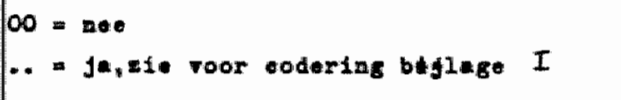 \\
\hline 50 & opdrachtgerer dioutadvies & 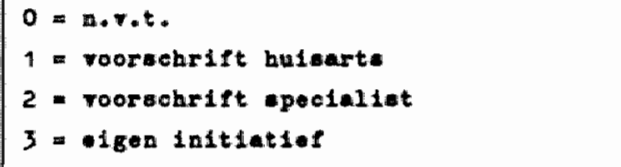 \\
\hline 51 & rolken & $\therefore i$ \\
\hline $52-53$ & 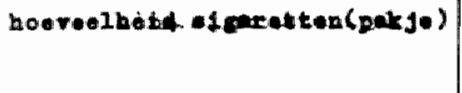 & $\begin{array}{l}\text { po geen/njt.t. } \\
\text { - antal pakjes per woik }\end{array}$ \\
\hline $54-55$ & mooreal held ameg & $\begin{array}{l}00=\text { geon/m.r.t. } \\
\text { = anter pakjes por week }\end{array}$ \\
\hline $56-57$ & hoorelheld algaren/algart jod & $\begin{array}{l}00 \text { - goen/n.r.t. } \\
\text { - a antal a lgaren/eigaurtjea per weok }\end{array}$ \\
\hline $58-59$ & hoevelueld pijptibuk & 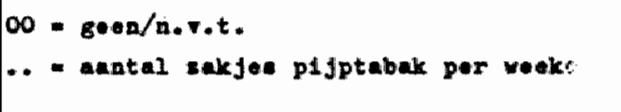 \\
\hline $60-61$ & 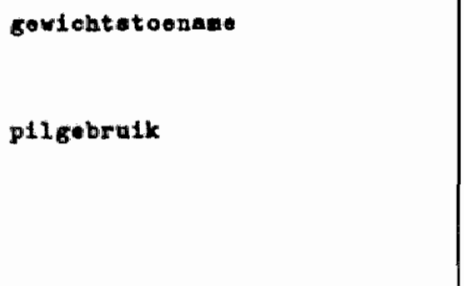 & 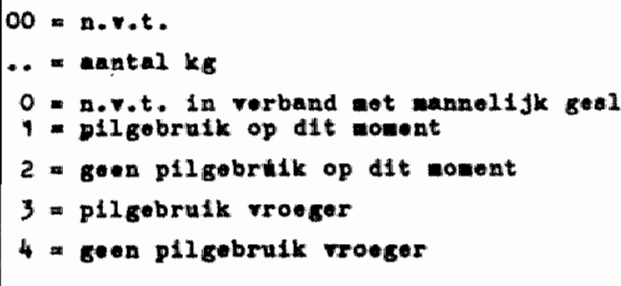 \\
\hline $64-65$ & antial Jaron pligebraik & $\begin{array}{l}00=n_{*} t_{*} \\
\ldots=\text { antal jarem }\end{array}$ \\
\hline
\end{tabular}




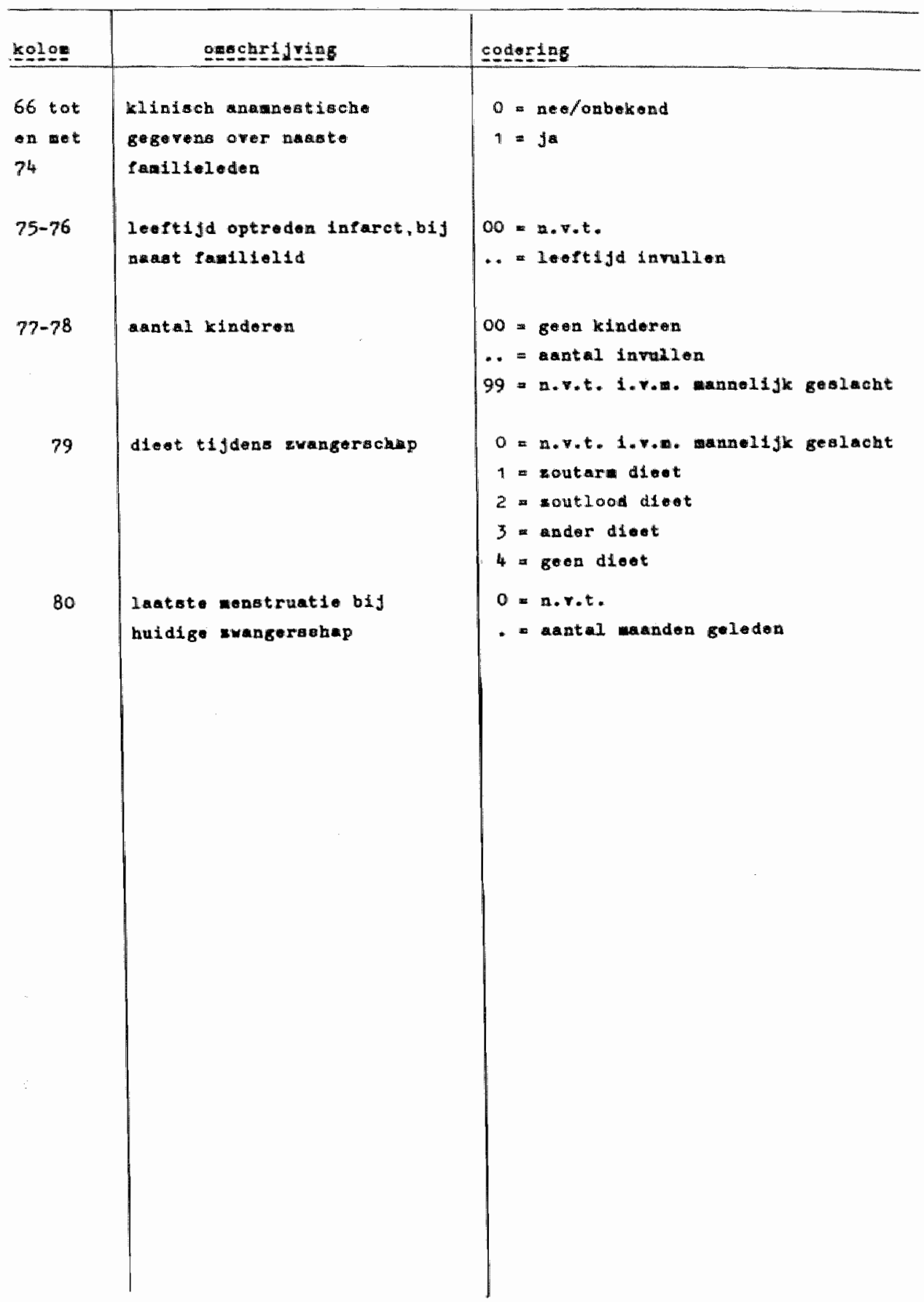


210

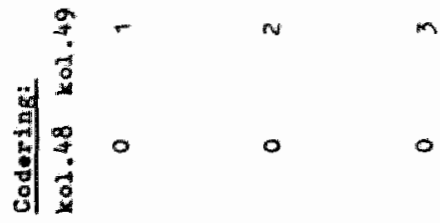
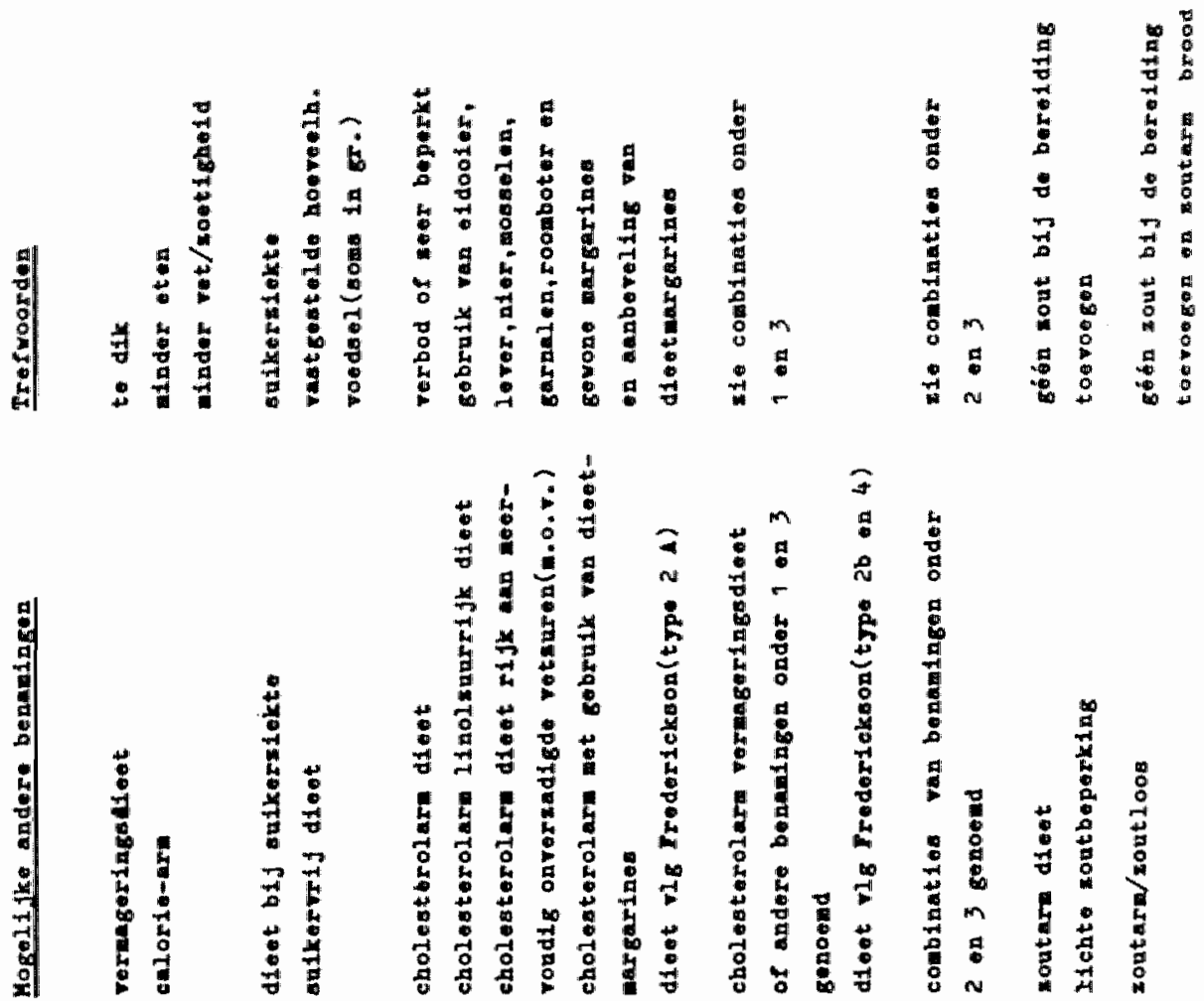

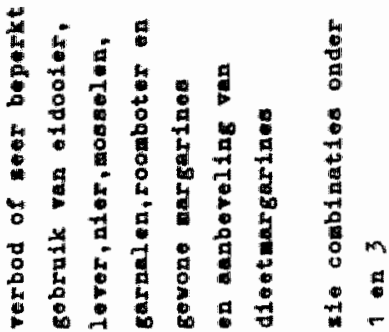

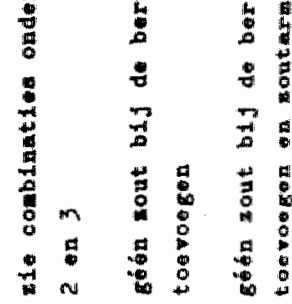

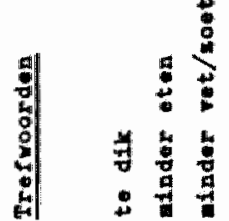

0
0
0

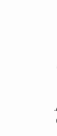

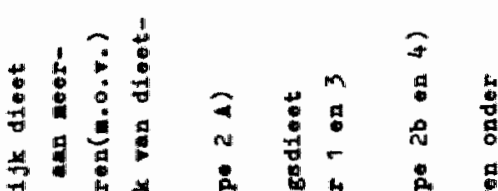

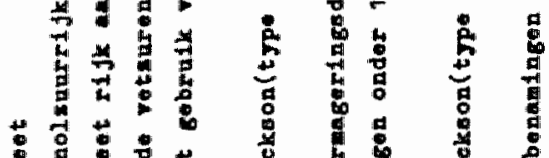

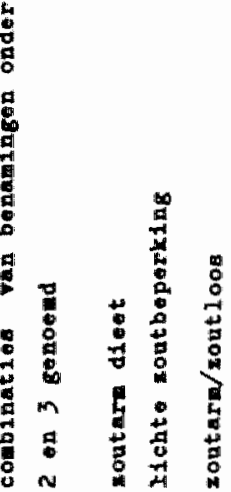

몀
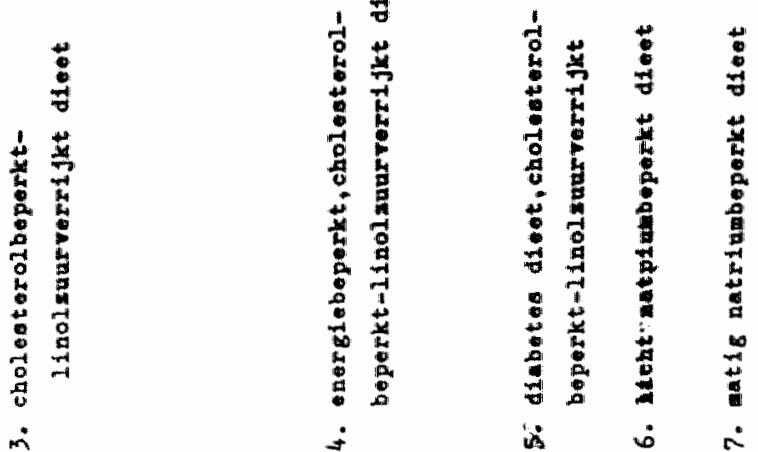


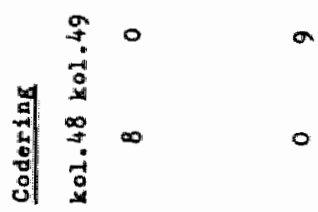
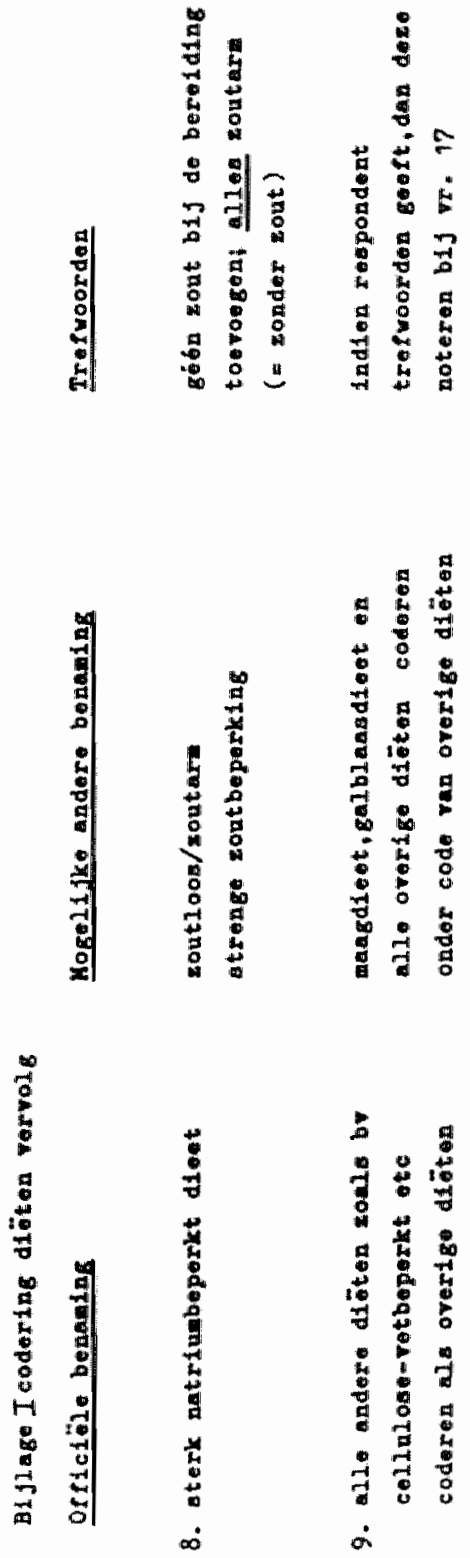

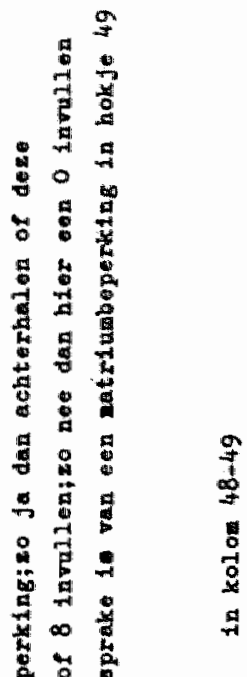

एँ 명

:

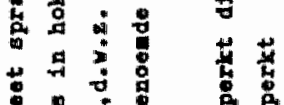

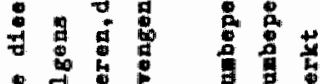

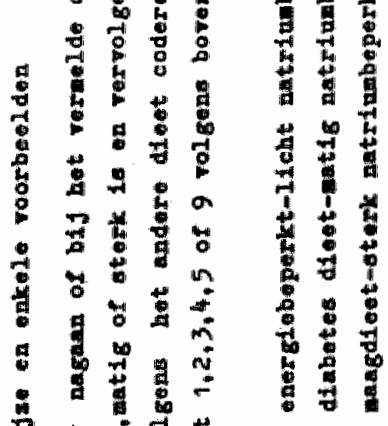

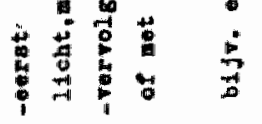




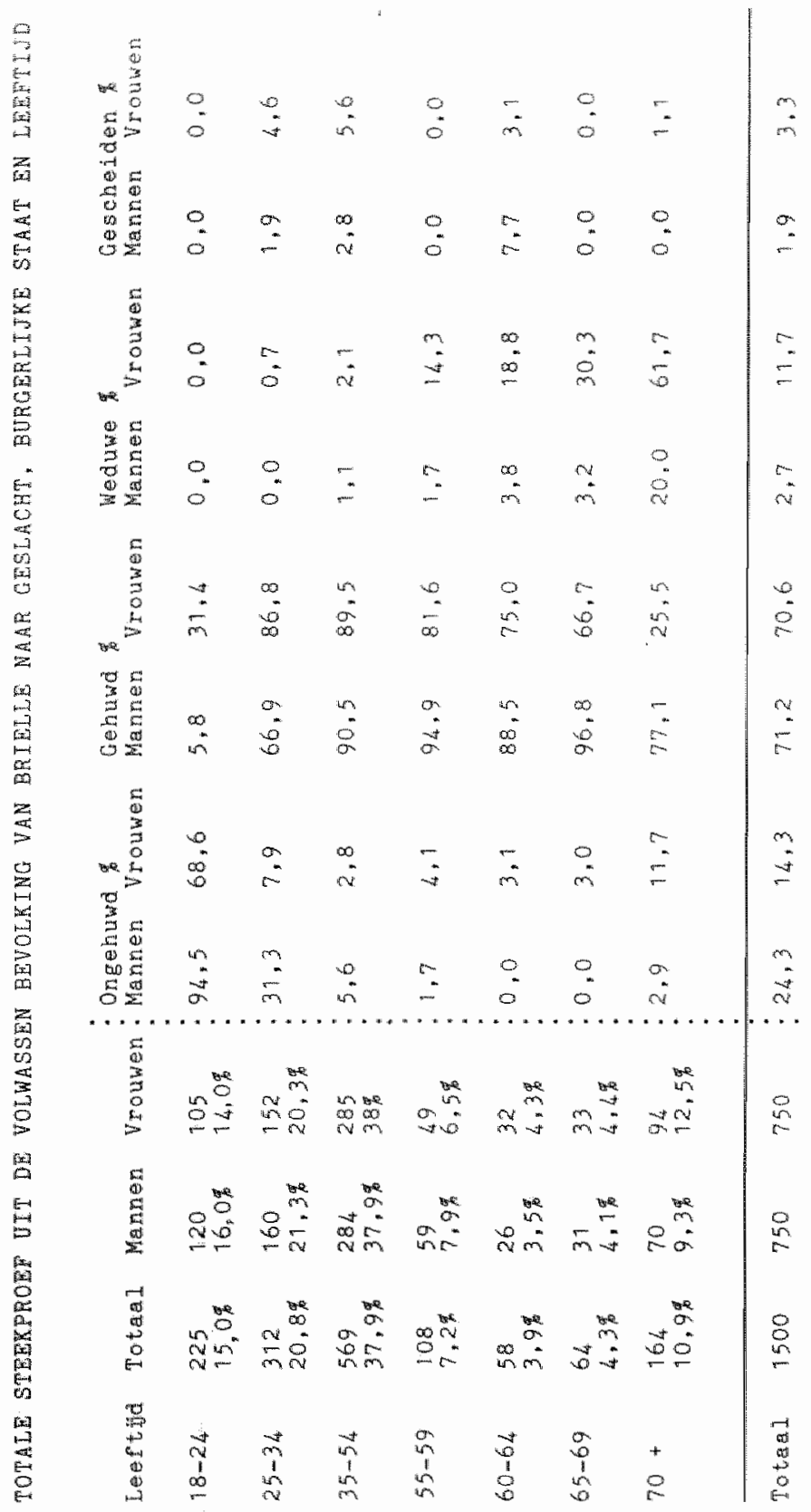




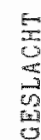

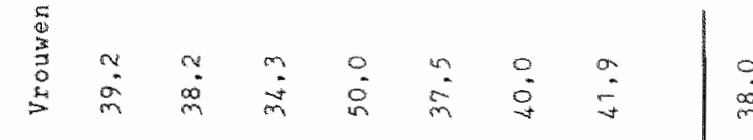

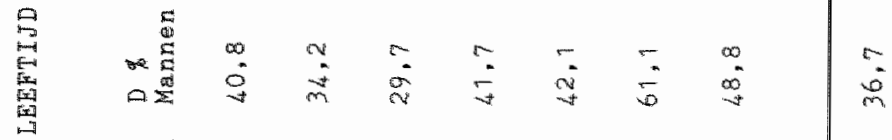

赵

告

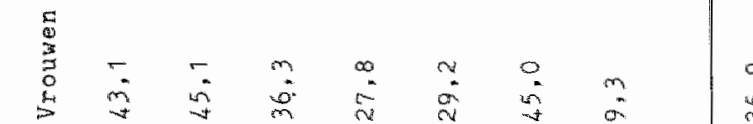

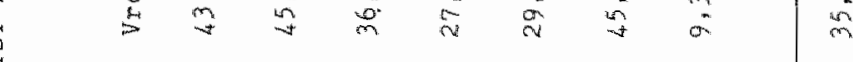

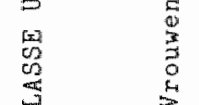

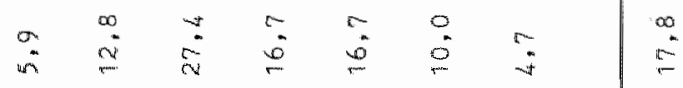

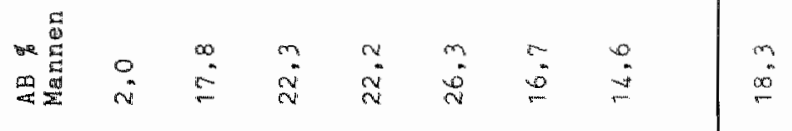

罯

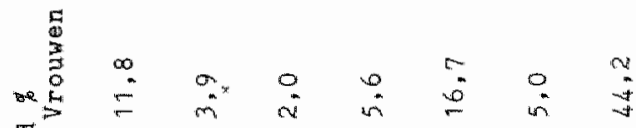

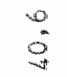

"I

E

焉

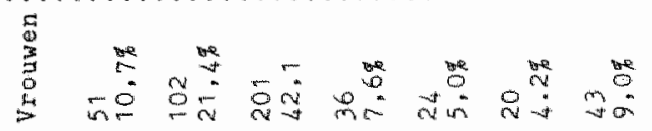

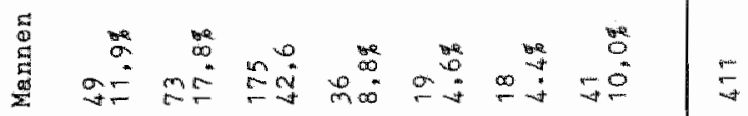




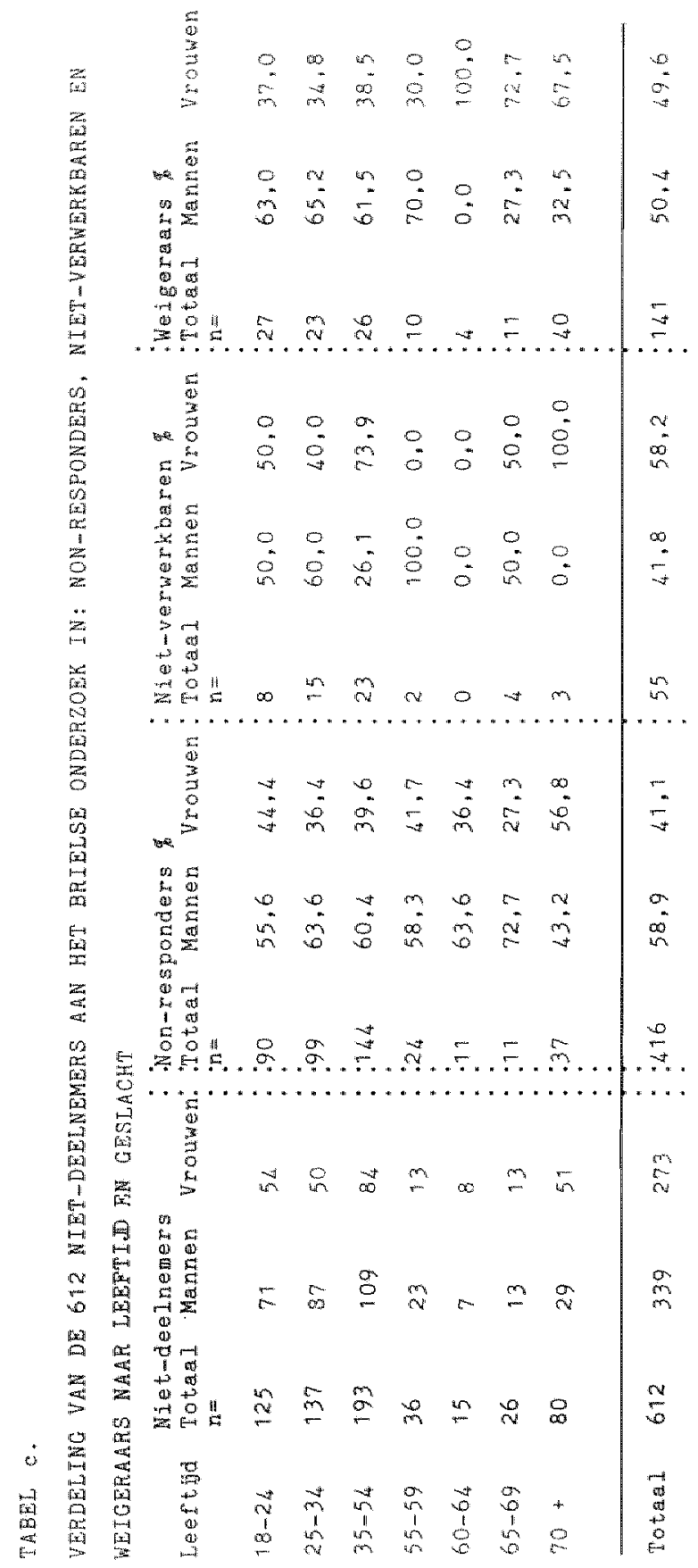




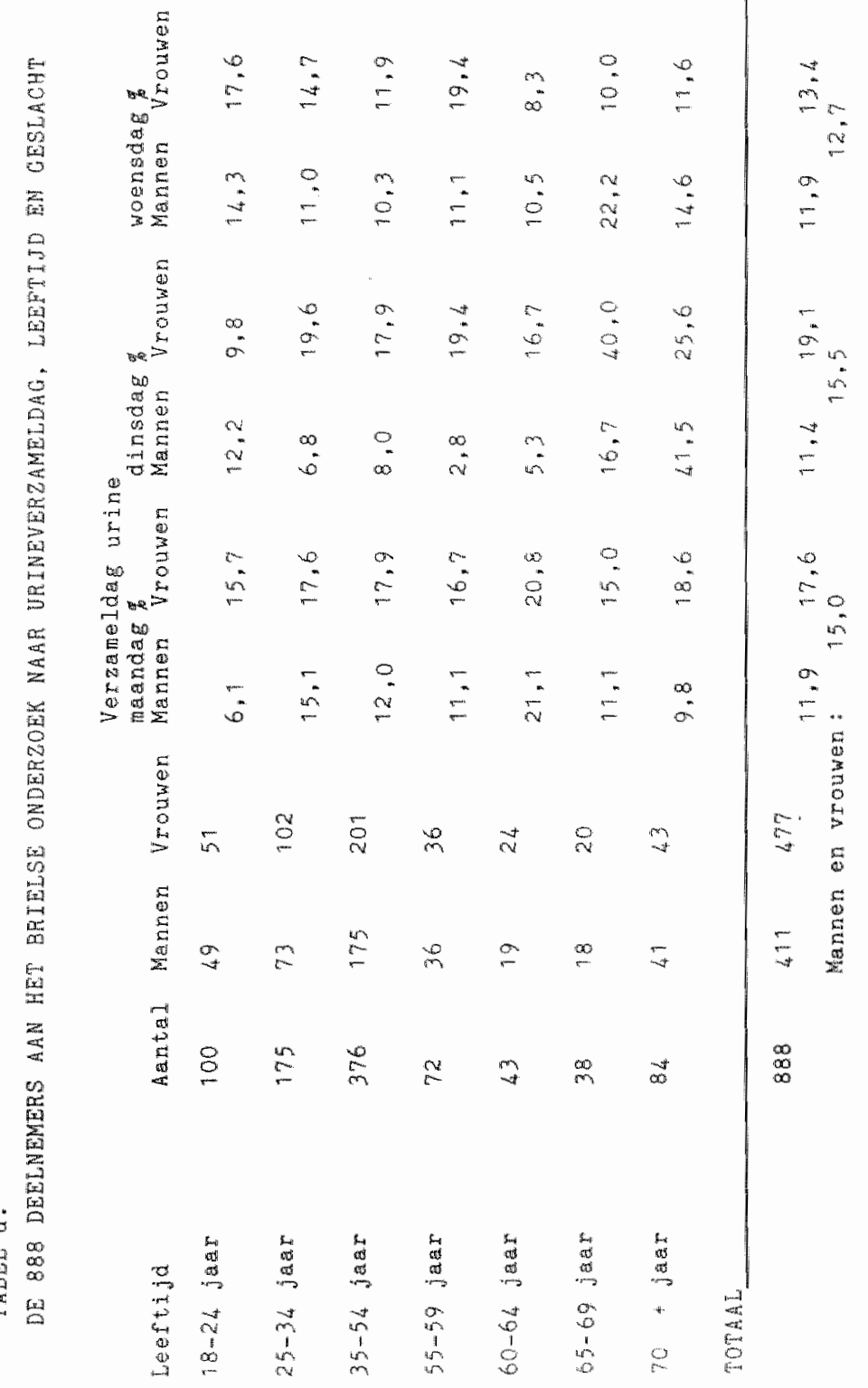




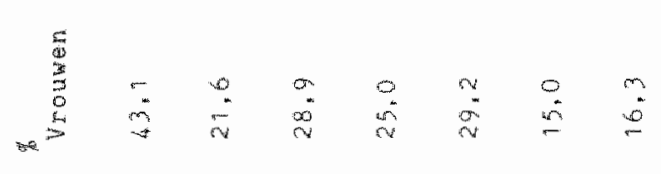

idith

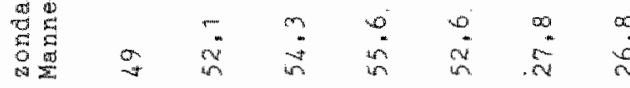

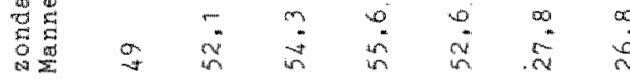

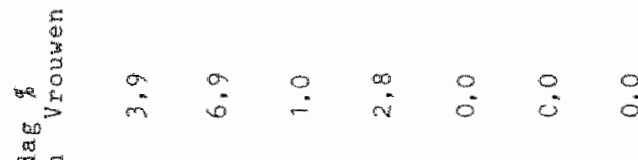

(1)

$\underset{+\infty}{+\infty}$

is

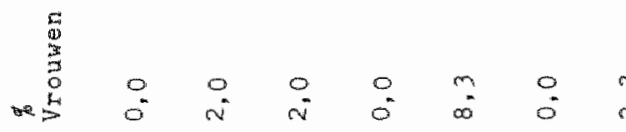

an

牙:

- $\operatorname{tat}_{\mathrm{i}}$

क $>$

$\begin{array}{lllllll}\infty & \infty & 0 & 0 & 0 & 0 & 0 \\ 0 & 0 & -1 & 0 & 0 & m & 0\end{array}$

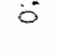

$-m$

$\underbrace{1}$

tol tol

10

80

$\rightarrow \infty$

$0 \quad 0 \quad 0 \quad \infty \quad 0$

0

$2 \quad-$

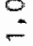




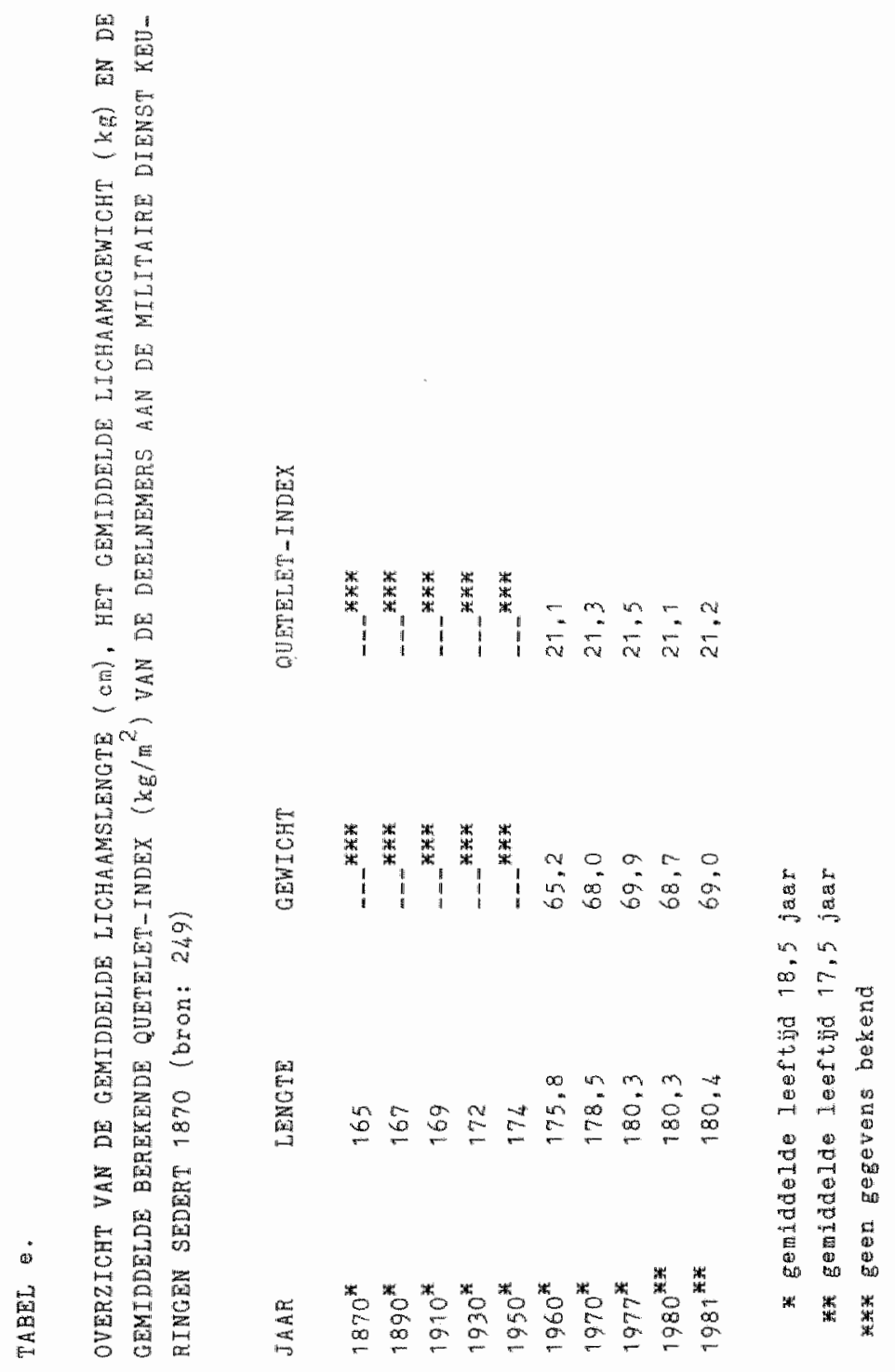




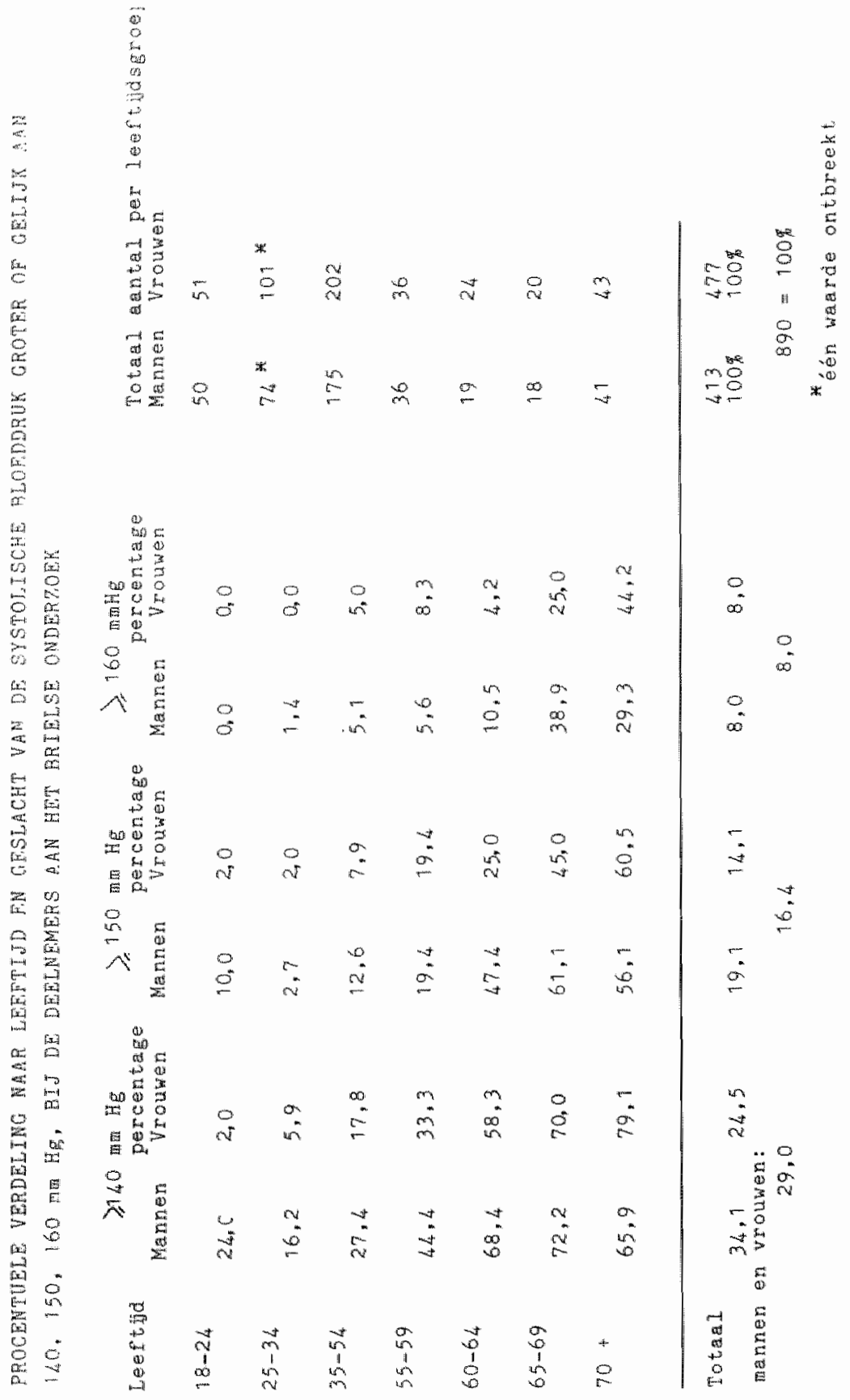




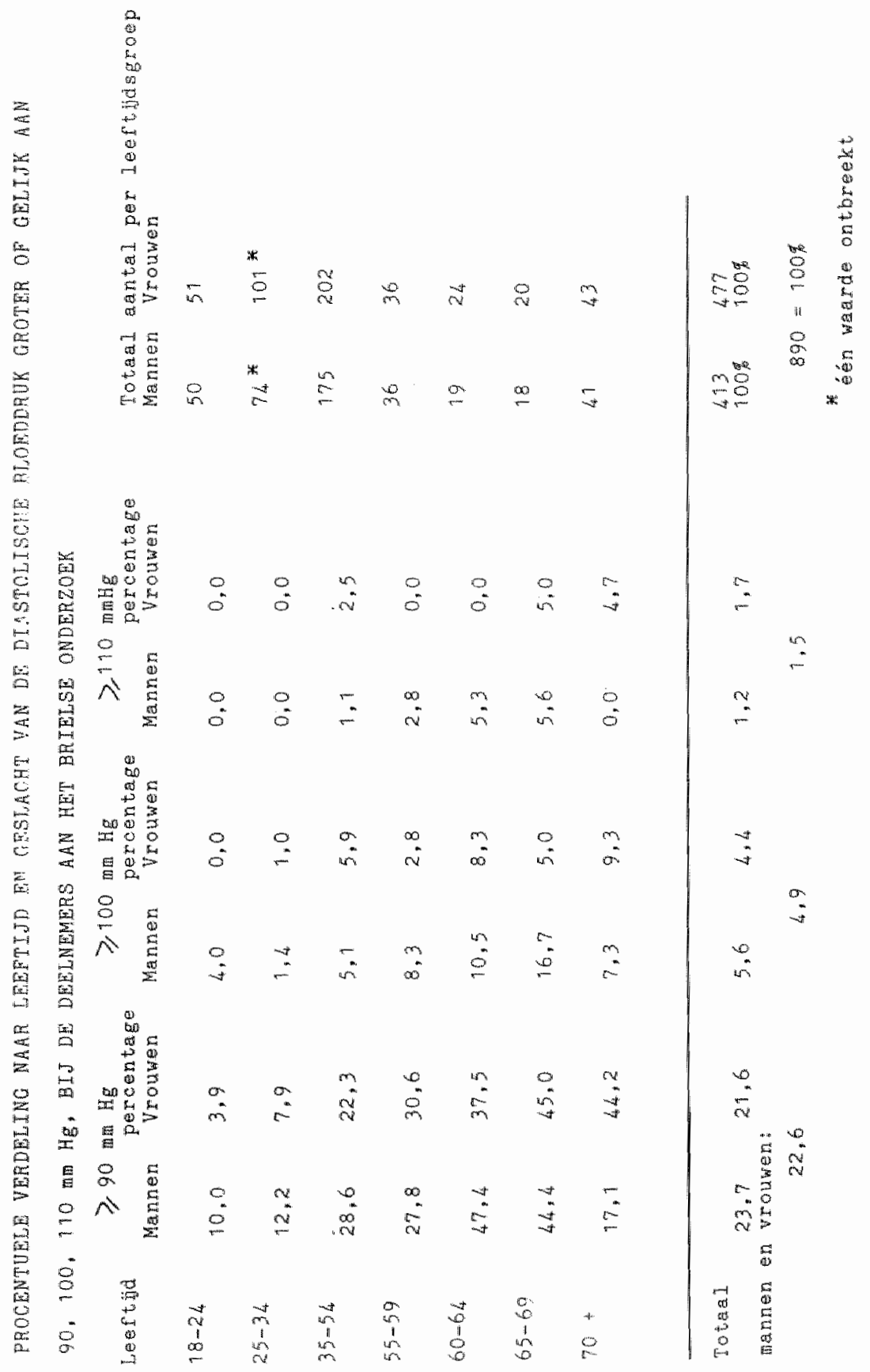




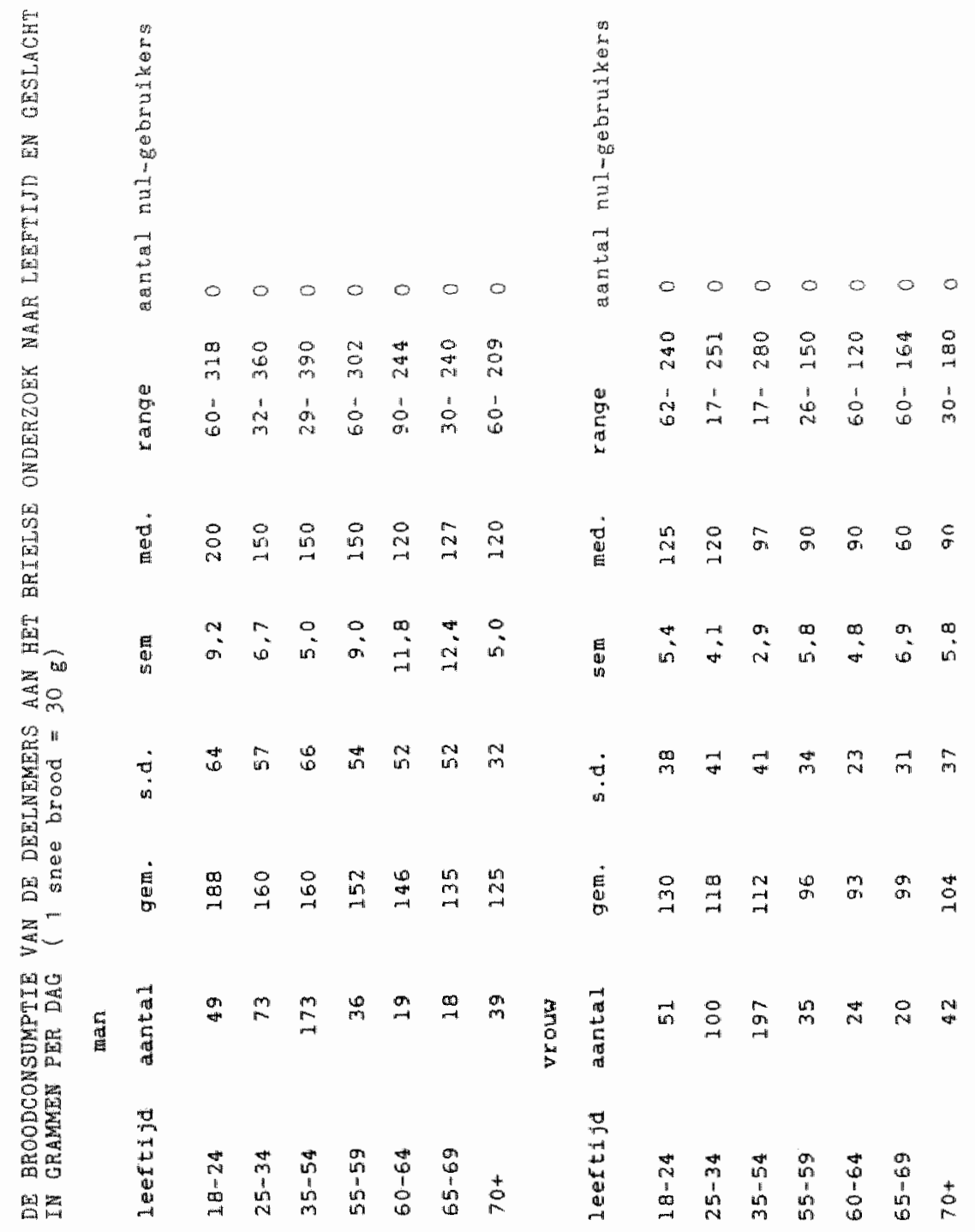




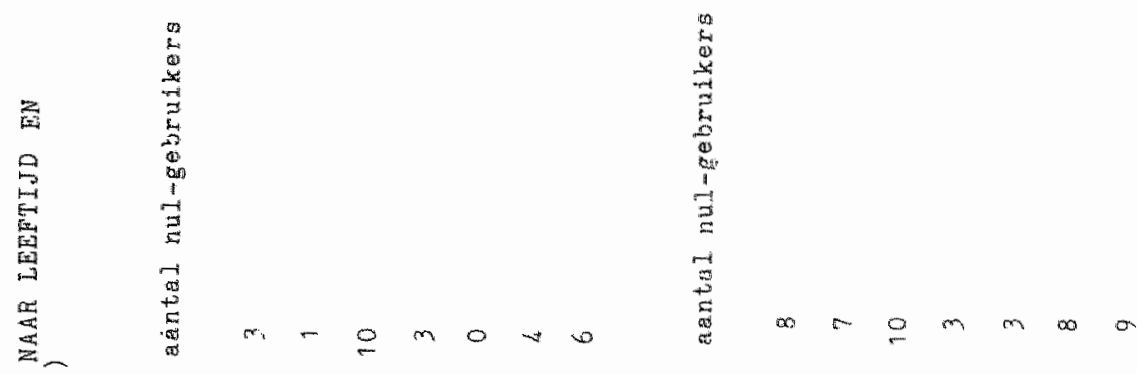

前象

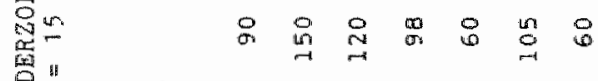

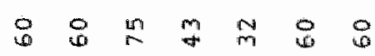

言范

尊

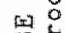

o 0

대

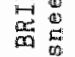

魚-

ty

$\frac{1}{0}$

逼

䍗管

(x)

$\lim _{0}$

${ }^{2}$

족몸 界品

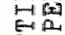

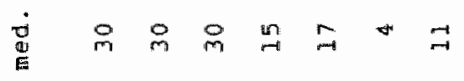

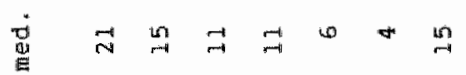

m m m $m$ m

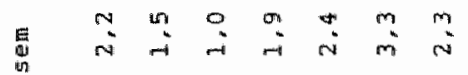

गे ल

का एक

\section{i}

용

tat

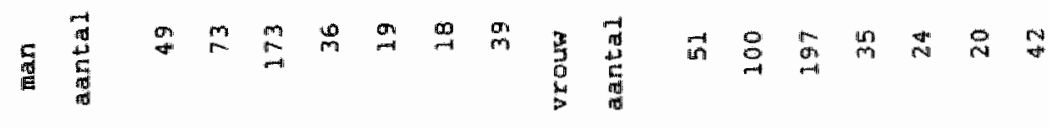

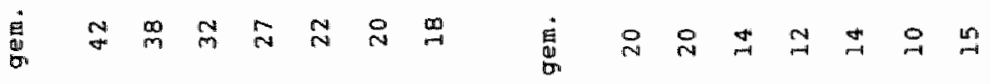

$+1$

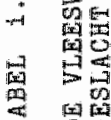

垈

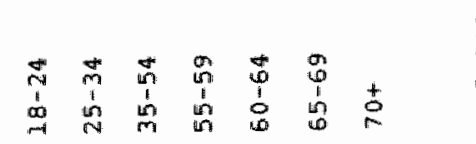

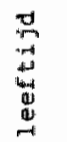

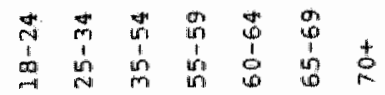




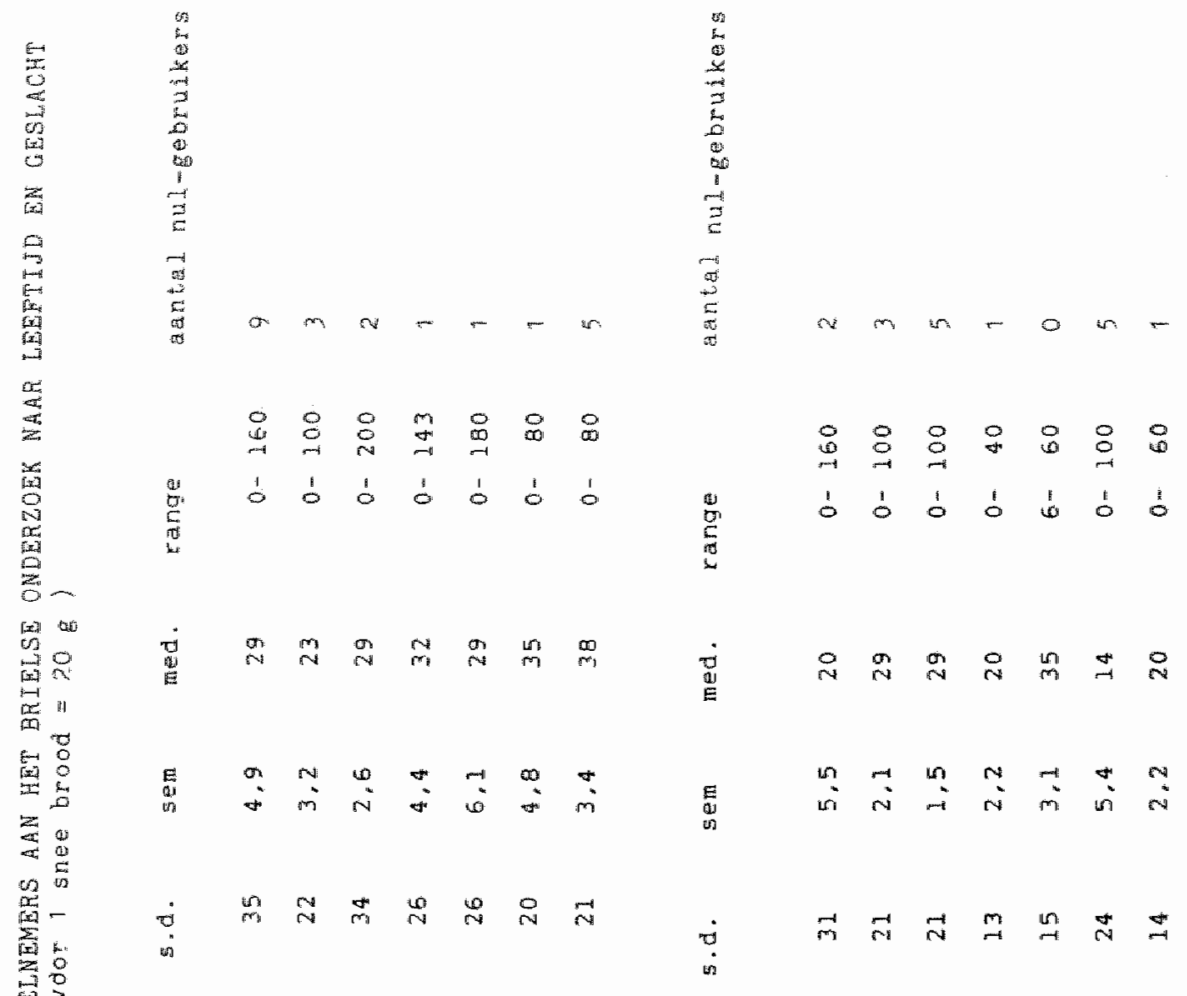
ind on

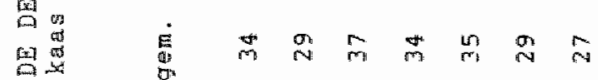

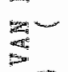

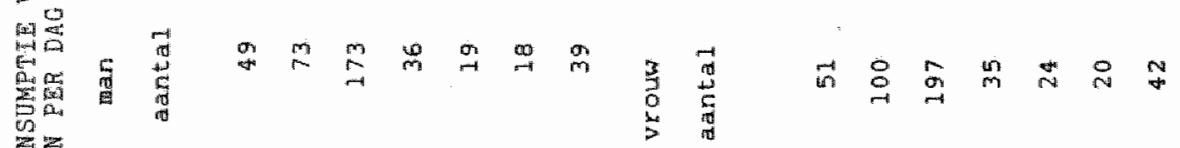
- 0 


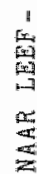
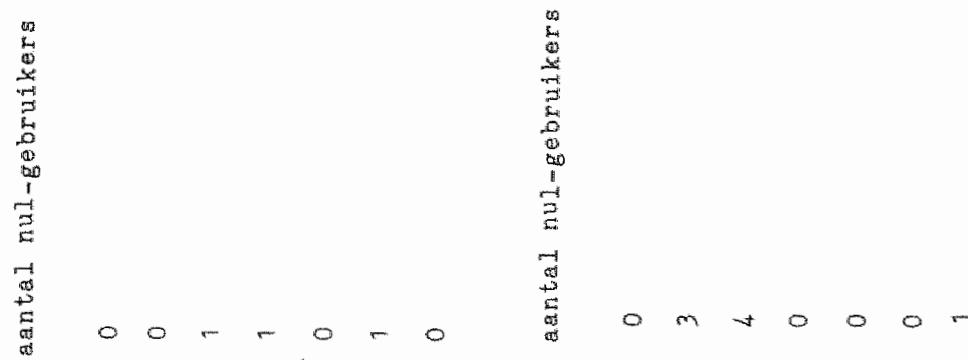

[n]

f되

क

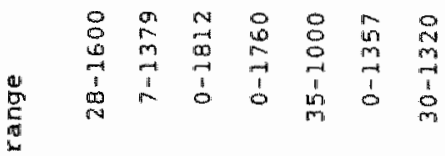

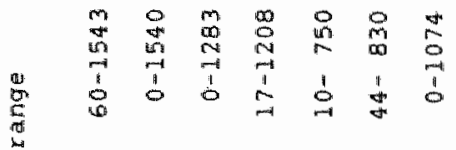

要

og

[x]

$x_{1}^{2}$

$z_{x \rightarrow 1}$

兵

${ }^{2} x^{3}$

20

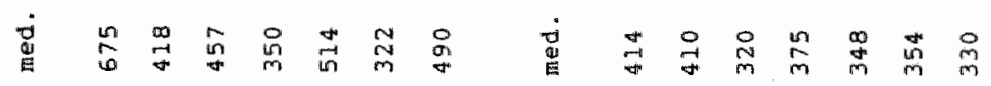

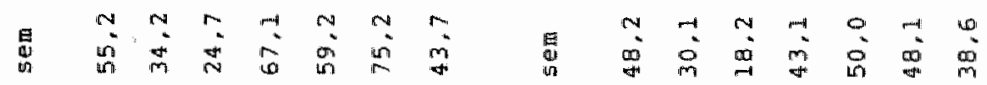

(x)

$\lim _{t \rightarrow \infty}$

o

点我

,

8 ?

$Q$

Es

0

要

赑

s

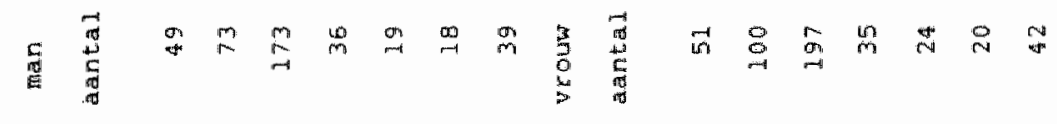

50

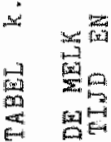

di

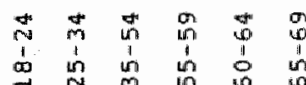

d

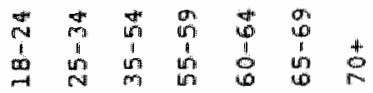


$x^{2}+1$

隐

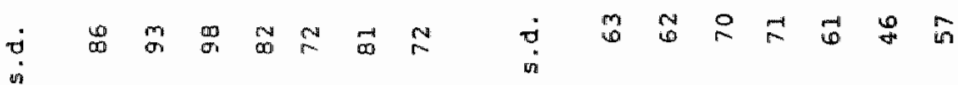

(ax)

$\sum_{\substack{\infty \\ \infty}}^{\infty}$

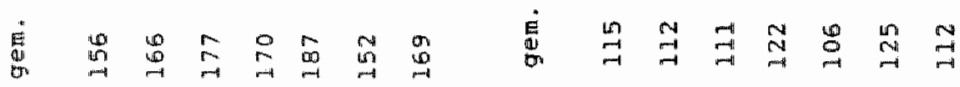

$\sum_{\substack{x \rightarrow 1 \\ t \rightarrow \infty}}$

$x^{2}$

$\log _{0} 0$

8

$\rightarrow$

霆

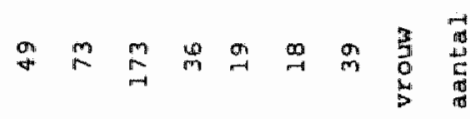

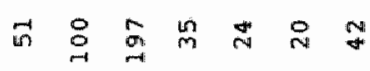

B.

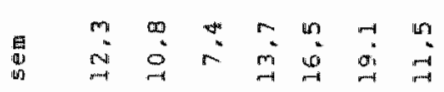

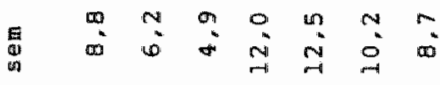

il

ind

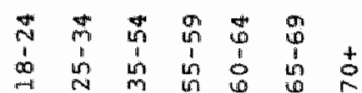

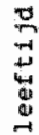

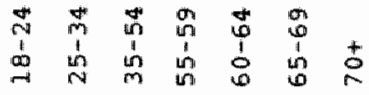




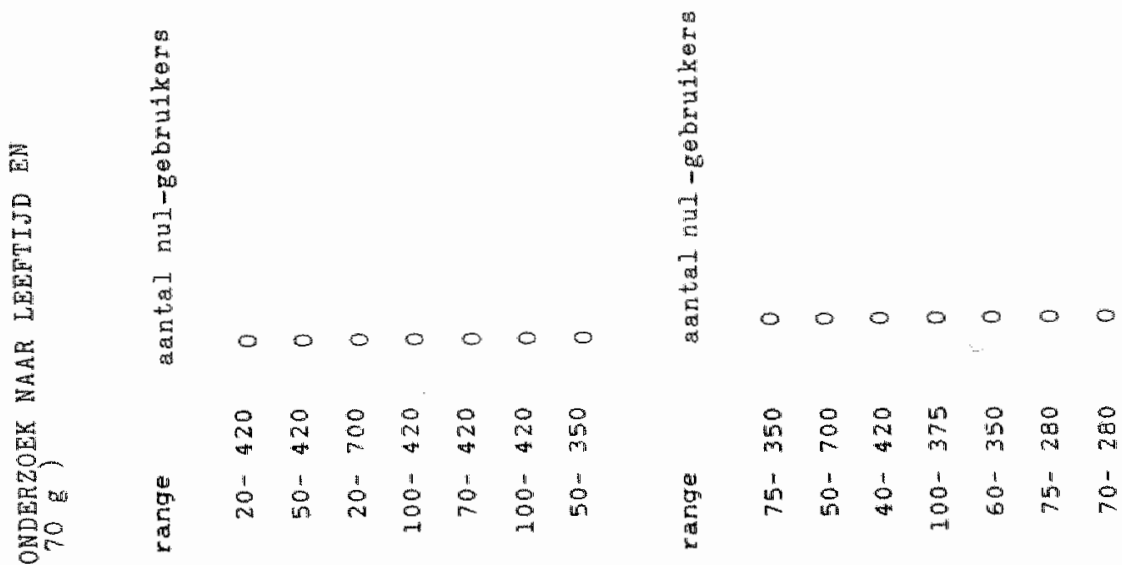

$y=1$

3

貿

$\epsilon_{1}$

空

B

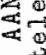

to

焉:

国

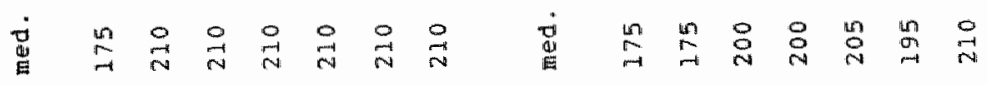

gan

$\underset{3}{\rightarrow \infty}$

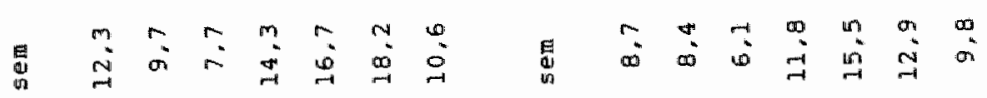

ए்

axil

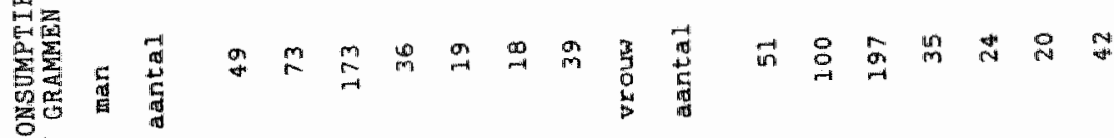

8

空

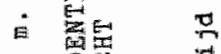

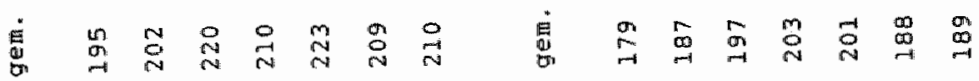

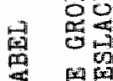

$\prod_{\substack{i \\ i}}$

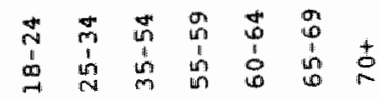

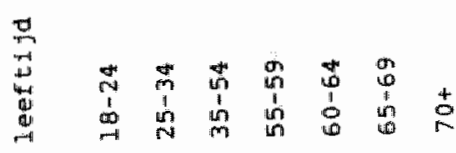




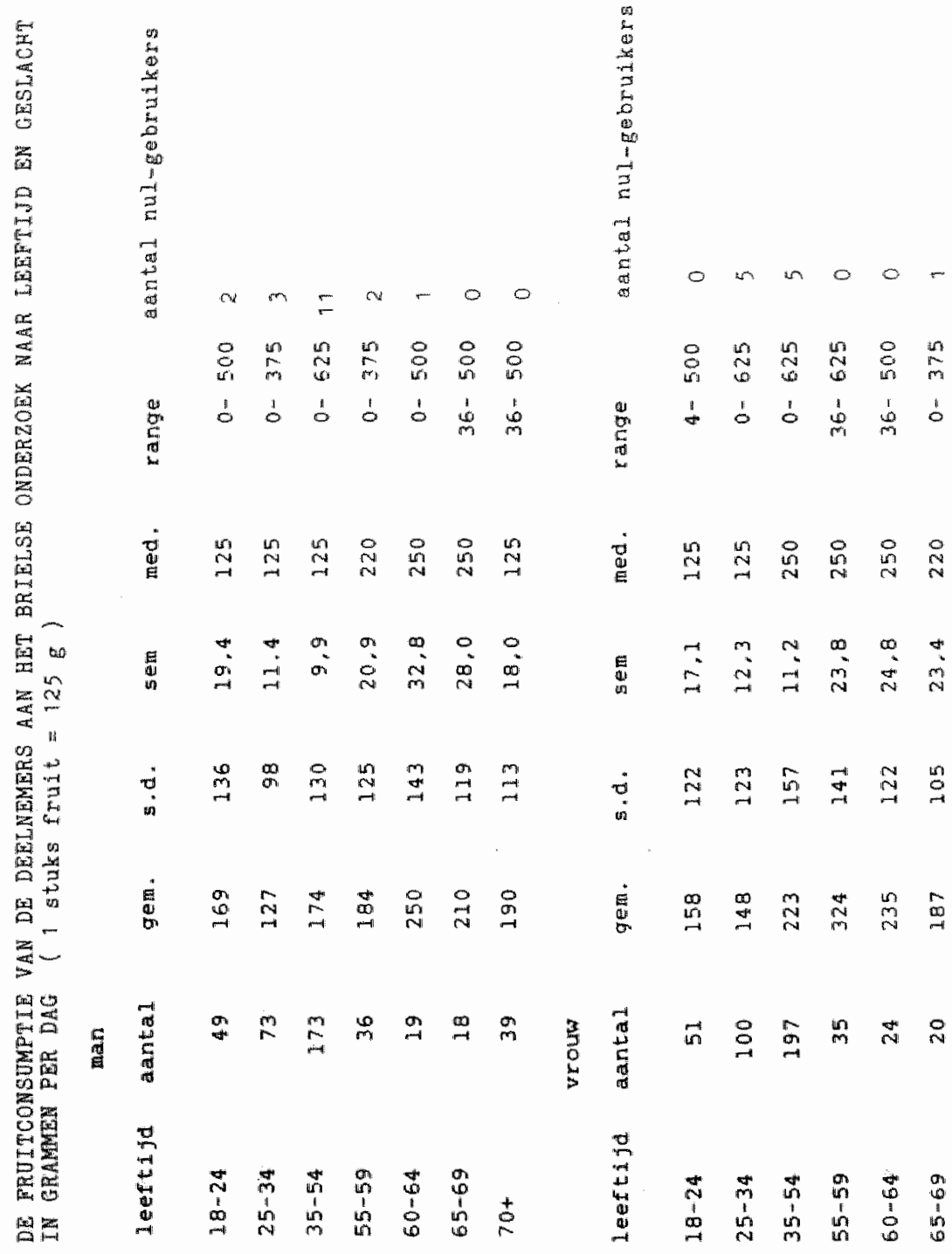



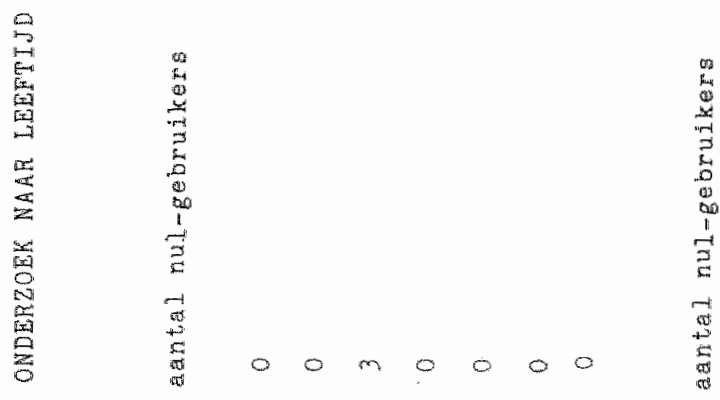

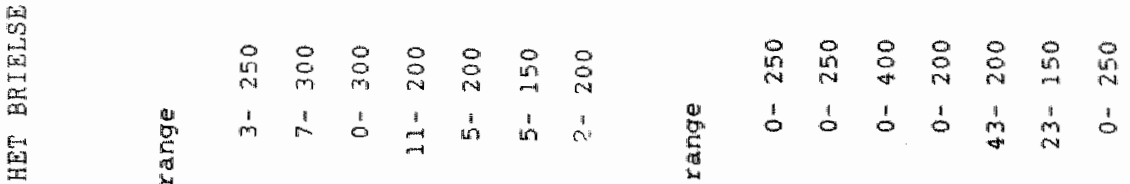

2

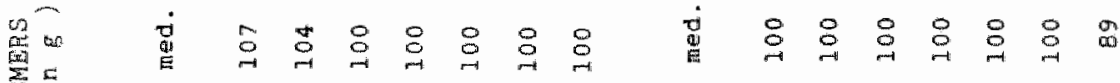
$\sum_{i=1}^{\infty}$

$\operatorname{lin}_{0 \rightarrow 0}$

$\Omega$ का

$\stackrel{4}{\rightarrow}$

a o

$\sum_{1}^{\infty}$

$>$

ia

EN

空感

要

:

$\sum_{i=1}$

8

5

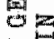

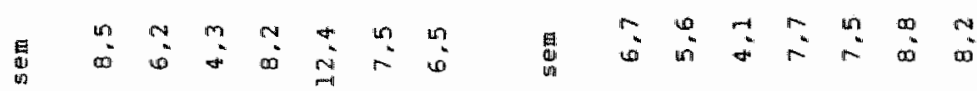

㱐

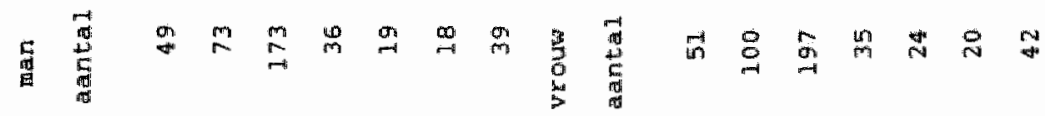

i) 1

and

$\operatorname{cic}_{x \rightarrow \infty} 00$

想

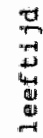

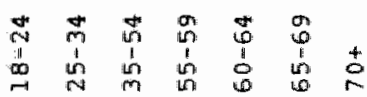

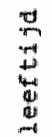

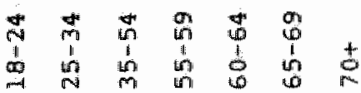




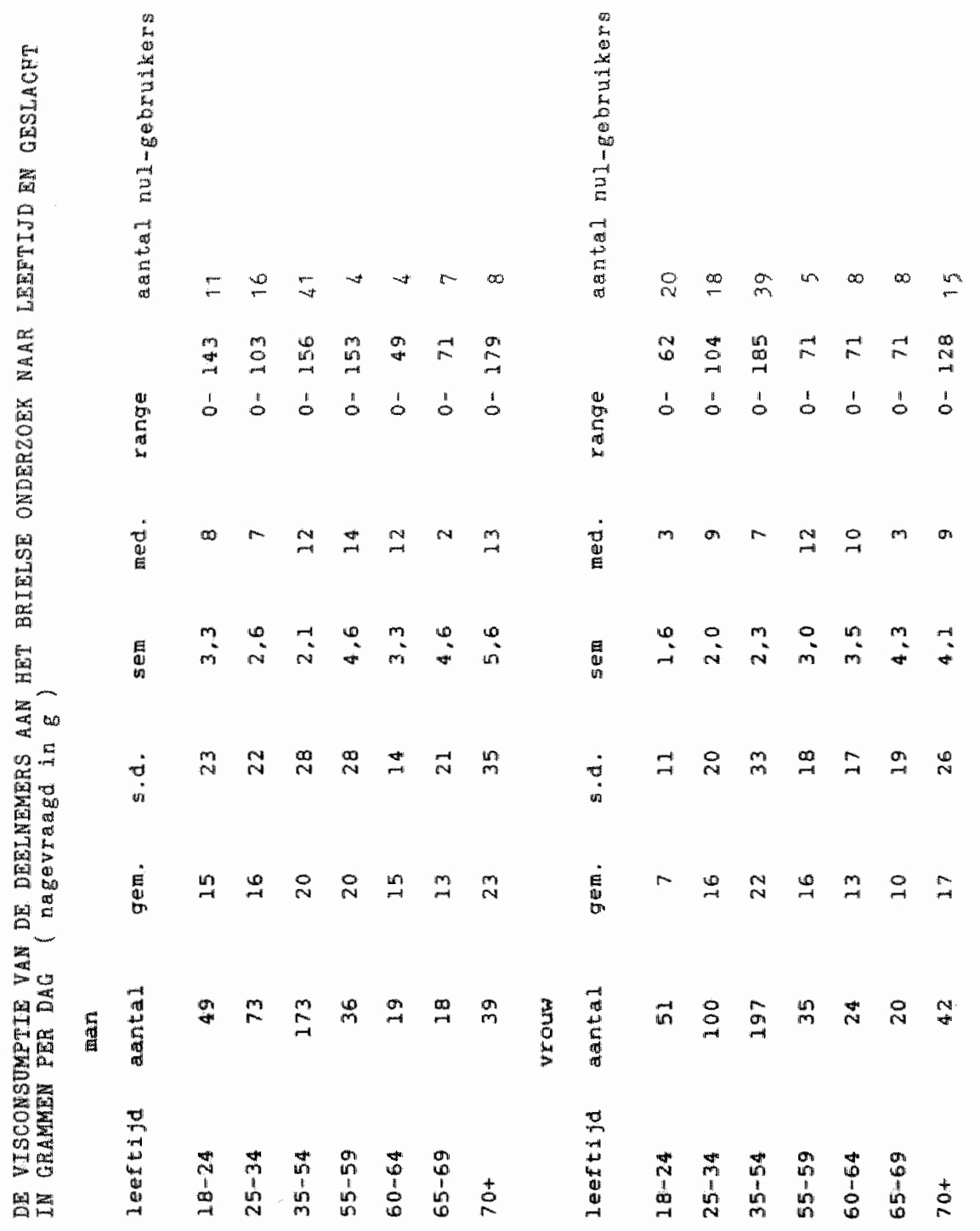




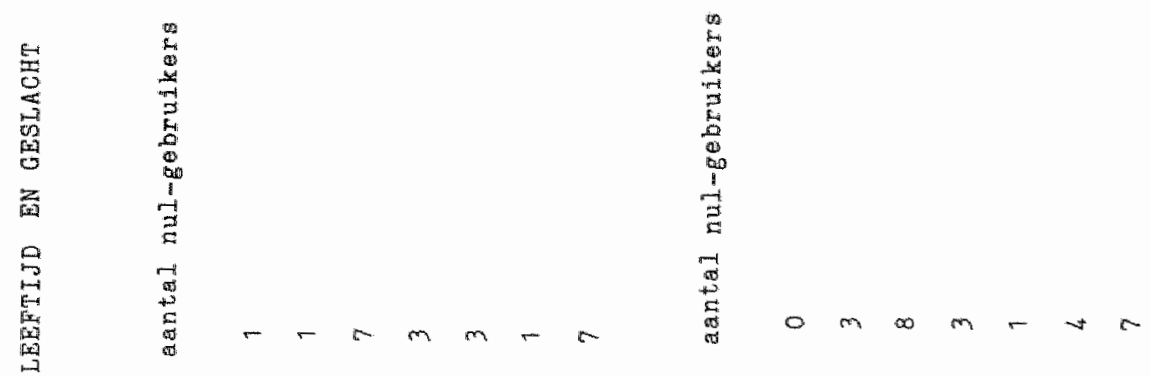

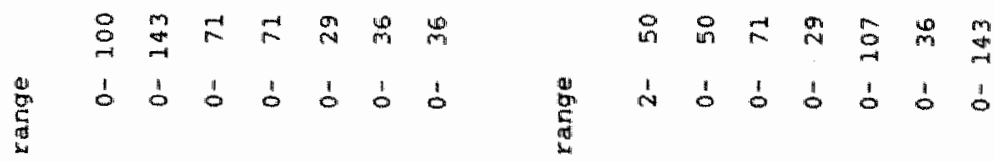

崖出

焉

z

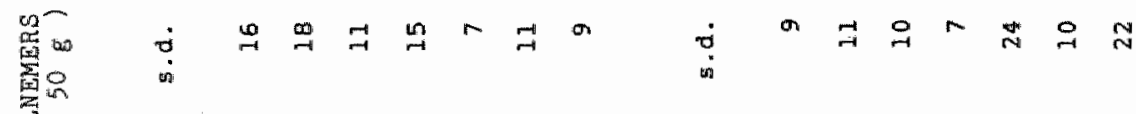

iोi

窝:

동-

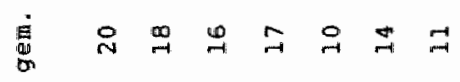

离

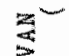

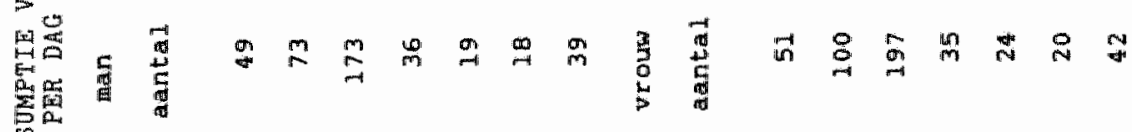

$\infty$

學

o

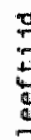

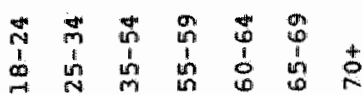

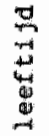

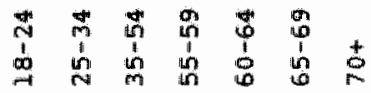




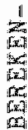

(x) $E$

(n)

2.

int

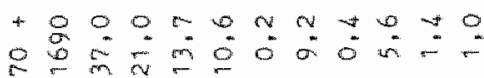

Q m $0 \div 0 \mathrm{~m}$ m 0

$\rightarrow$ m 0 क o 0 a 0 m

$\mathrm{g}_{0}$

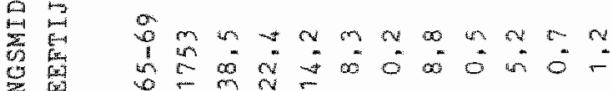

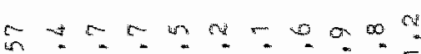

0

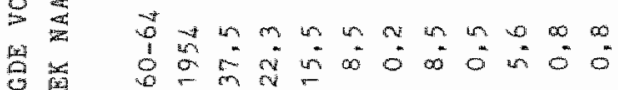

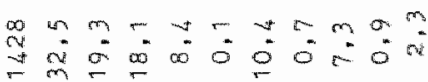

$=$

2

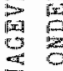

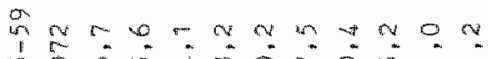

al यो दो की

$\therefore 0^{\circ} 0^{\circ}=0^{\circ} 0^{\circ}$

$\lim _{\rightarrow \rightarrow 1}$

$\lim _{1}$

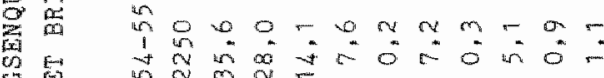

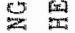

$\hat{\theta}_{1 \rightarrow 1}$

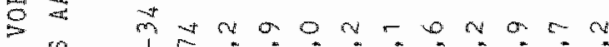

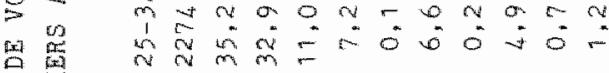

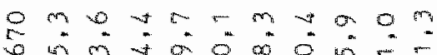

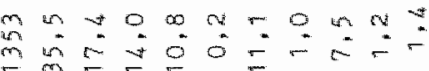

[xi]

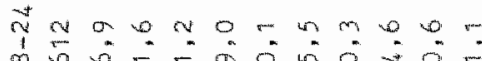

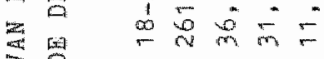

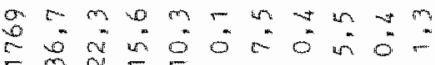

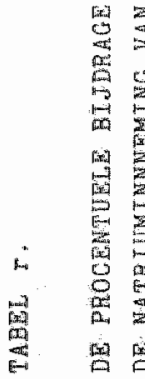

be.
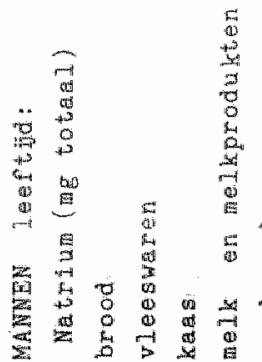

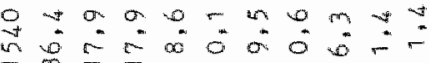




\section{DANKBETUIGING}

Voor mijn promotoren Prof.Dr.Ir. R.J.J. Hermus en Prof.Dr. F. Sturmans moet het geen eenvoudige opgave zijn geweest een perifeer werkend huisarts de meest basale kennis van wetenschapsbeoefening en schrijfkunst bij te brengen. Voor het geduld dat zij opbrachten, ben ik hen erkentelijk.

De Briellenaren die aan het onderzoek deelnamen, vormen de spil van het proefschrift.

De Gemeente Brielle bood steeds alle noodzakelijke hulp.

Mevrouw E. Stolk-Bergwerff had als doktersassistente een belangrijk aandeel in de praktische uitvoering van het onderzoek.

Mevrouw G. de Vries-Rem, doktersassistente maar vooral ook mijn dagelijkse rechter hand Mevrouw E. Sandford, doktersassistente, vingen de lawine van telefonische afspraken op.

Prof.Dr. J.V. Joossens uit Leuven was vooral in de begin fase nauw bij het onderzoek betrokken. Onder zijn leiding werd veel laboratoriumwerk verricht.

Prof.Dr.J.G.A.J. Hautvast en Prof.Dr. M.B. Katan waren met name in de eerste periode intensief bij het onderzoek betrokken. Veel laboratoriumbepalingen werden aan de Landbouwuniversiteit te Wageningen verricht.

Prof.Dr. W.H. Birkenhäger stelde zich steeds, vanuit een grote deskundigheid, vaderlijk achter het onderzoek op.

Prof.Dr. W. Brouwer was als referent betrokken bij de tot standkoming van het proefschrift.

Prof. Dr. F. ten Hoor leverde de opbouwende kritiek die een promovendus nodig heeft: na het lezen ervan gaf deze aanleiding tot moedeloosheid, bij nader inzien reden tot enthousiasme. 
Drs. R.J. Egger, Drs. M. Wedel en Mevrouw K. Hulshof, dietiste, allen werkzaam bij CIVO Toxicologie en Voeding TNO te Zeist, namen de verwerking van de vele onderzoeksgegevens voor hun rekening.

Ir. M. van Dongen corrigeerde de verschillende concept-teksten uitermate kritisch.

Dr. A.H.M. Kerkhoff begeleidde op hooggeleerde wijze mijn wankele schreden op het wetenschappelijke pad. Aan de voltooiing van dit proefschrift heeft hij in belangrijke mate bijgedragen.

Mijn collega" $\$$ van de Huisartsengroep Brielle: H. Kamma, M.S. Korevaar, B.P. Ponsioen en C. J. in 't Veld toonden steeds veel begrip voor de onrust die de uitvoering en verwerking wan het onderzoek met zich mee bracht. Collega In "t Veld nam in de "schrijffase" op zeer kundige wijze mijn praktijk waar.

Mevrouw M.J. Desmarets vervaardigde de grafische woorstellingen.

De Nederlandse Hartstichting subsidieerde het hele onderzoeksproject in ruime mate.

De organisatie Moeders voor Moeders leverde belangeloos de urineverzamelflessen.

De firma Smith, Kline \& French ondersteunde de tot standkoming van deze uitgave.

Mevrouw A. van Binsbergen-Ingellse, medisch analyste verwerkte de verzamelde urines tot laboratoriummonsters, administreerde en controleerde de onderzoeksformullieren en verrichtte rekenwerk aan de vele onderzoeksgegevens. Zij corrigeerde de diverse manuscripten.

Annette, Margot en Laurine de dank die ik aan jullie verschuldigd ben, laat zich niet opschrijven. 


\section{CURRICULUM VTTAE}

Jacob-Jan van Binsbergen werd geboren op 5 maart 1946 te Utrecht.

$\mathrm{Na}$ het eindexamen aan de H.B.S. B "F. de Munnik", studeerde hij geneeskunde aan de Rijksuniversiteit in de Domstad. Het artsexamen besloot in 1972 de medische studie waarna een wissel-assistentschap in het St. Joseph Ziekenhuis te Veghel (NB) begon. In 1973 volgde hij de Nationale Tropencursus aan het Koninklijk Instituut voor de Tropen in Amsterdam. Van eind 1973 tot eind 1976 werkte hij in Kenya: aanvankelijk in het Machakos Provincial Hospital, daarna als "doctor in charge" van het Kangundo Sub-district Hospital. Sedert 1977 is de auteur werkzaam als huisarts in Brielle.

Hij is getrouwd met Annette Ingelse en heeft twee dochters, Margot Annemiek en Laurine Frédérique. 